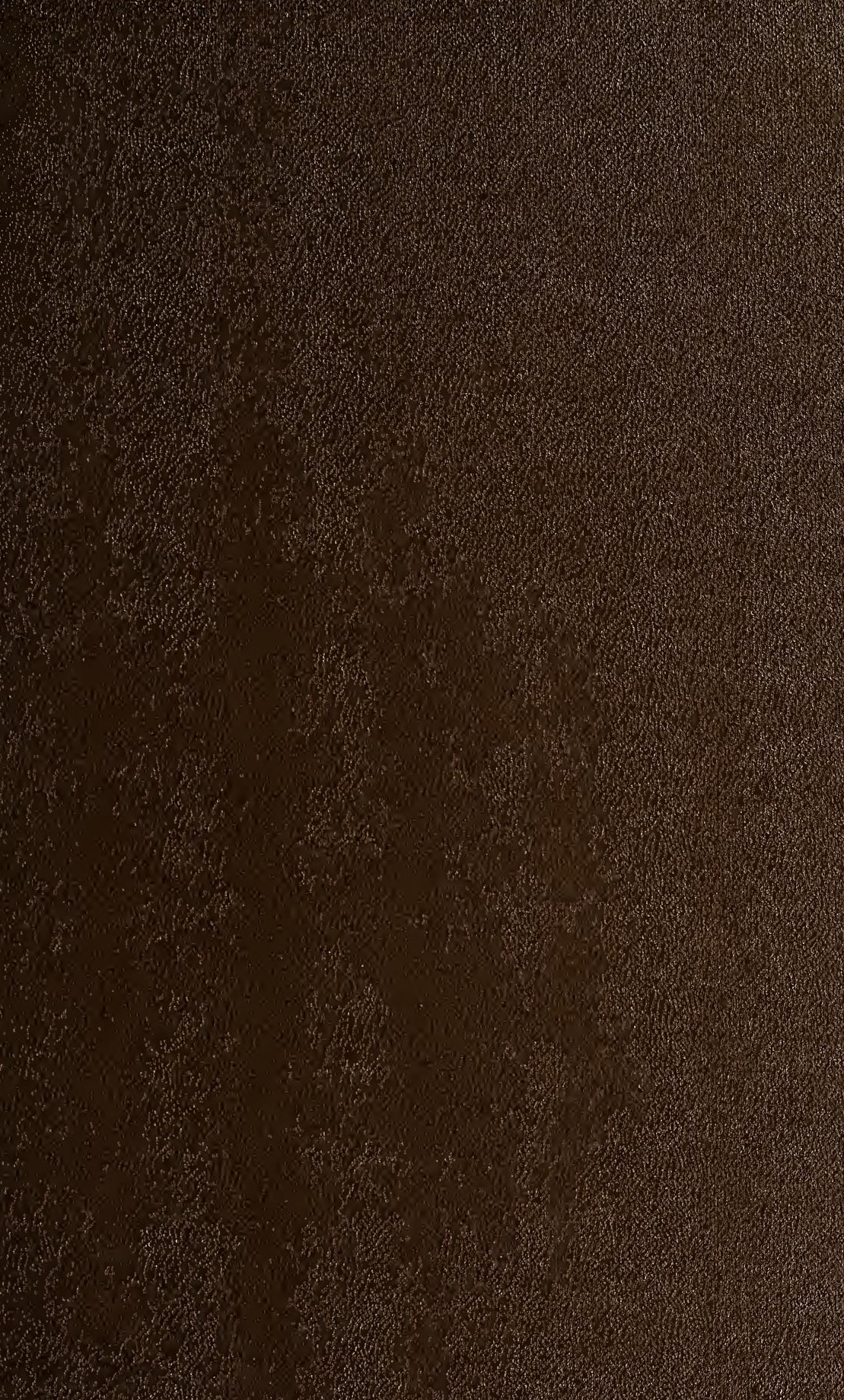

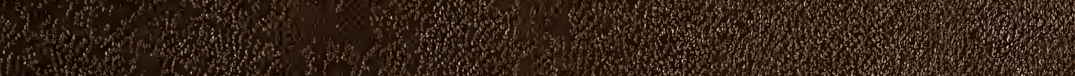

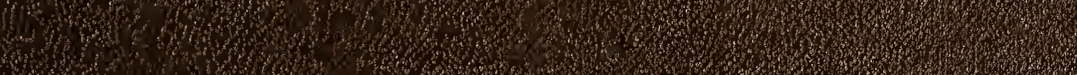
1.

1.7.

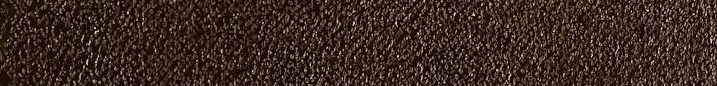

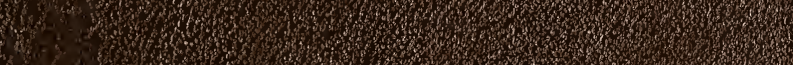
W

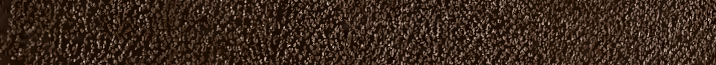
4. W (1) 


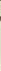

1SNI NHINOSHIIWS ${ }^{2}$ S I Y甘Y8 $817^{-1}$ LIBRARIES $^{2}$ SMITHSONIAN INSTITUTI
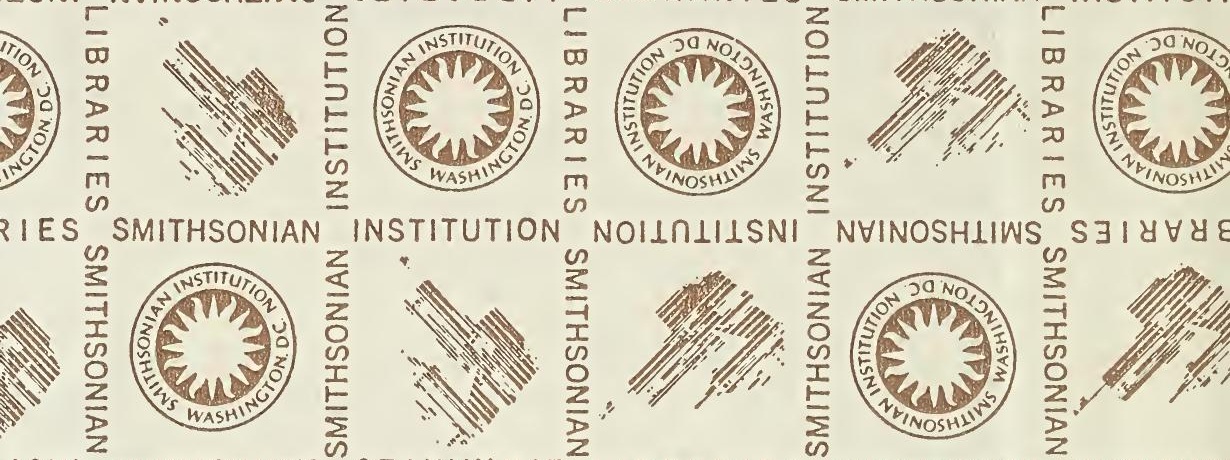

ISNI NHINOSHLIWS
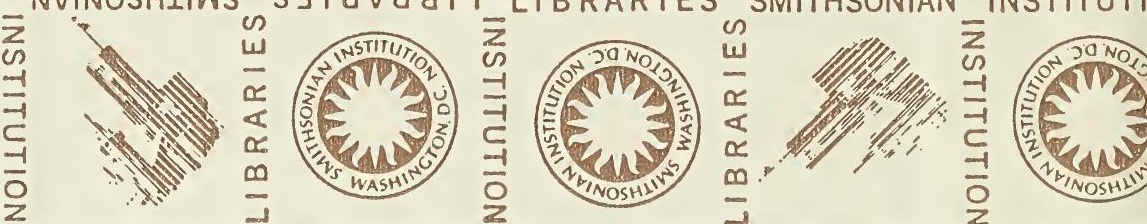

RIES
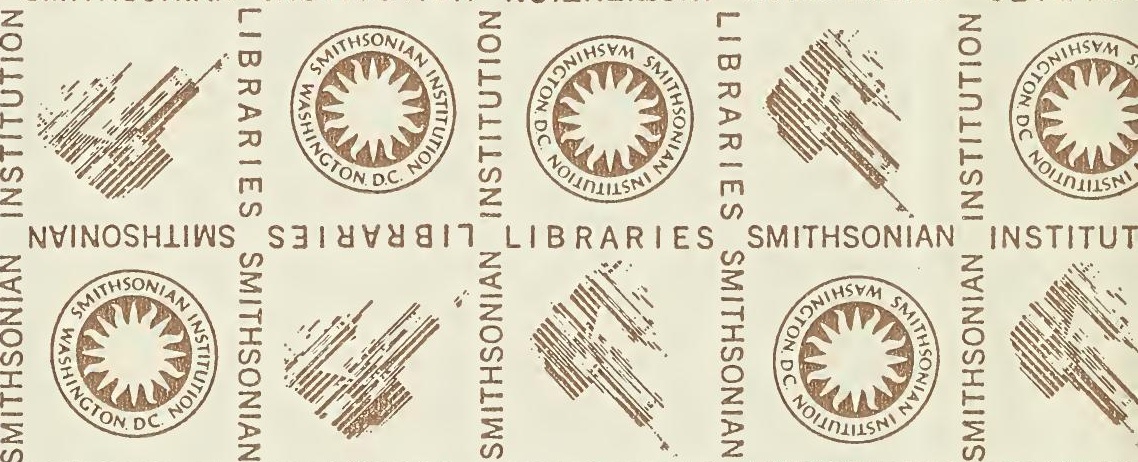

INSTITUT

RIES SMITHSONIAN

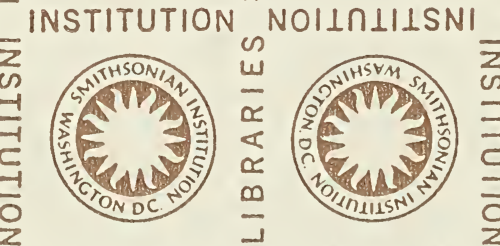

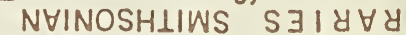

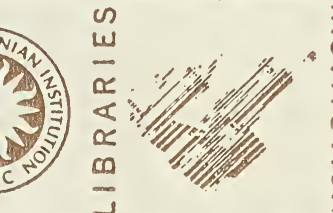

$11 \mathrm{SNI}$ " $\mathrm{NHINOSH \perp IWS}$
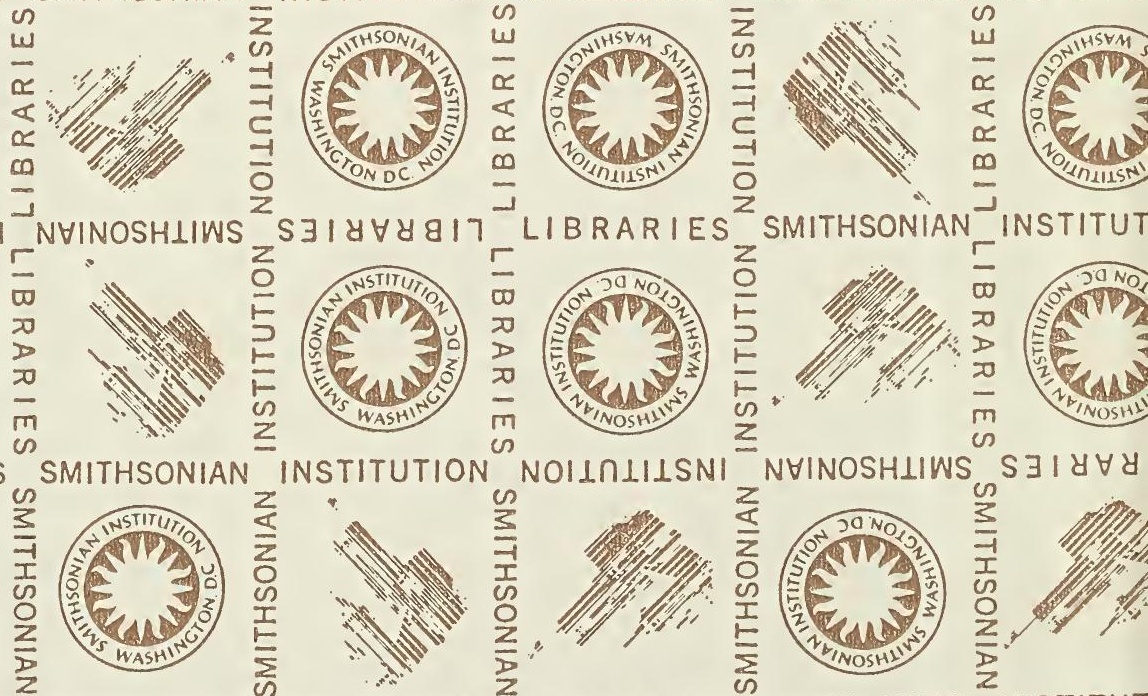

NHINOSHLIWS S $\exists I Y \forall \forall$
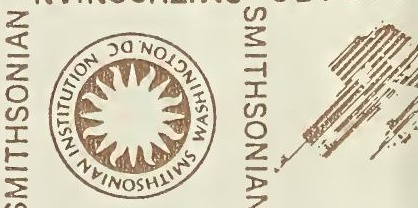

ILSNI NHINOSHIIWS

S $\exists 1 d \forall \forall 8$ व 17

LIBRARIES

SMITHSONIAN INSTITUT

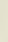

w

商

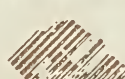

z 


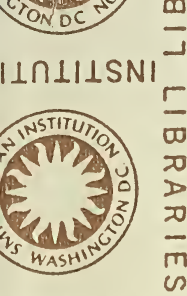

0 ONDC

LnIIISN
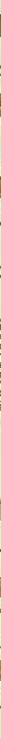

INST!
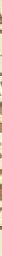

$1 \perp \cap \perp \mid \mathrm{SN}$
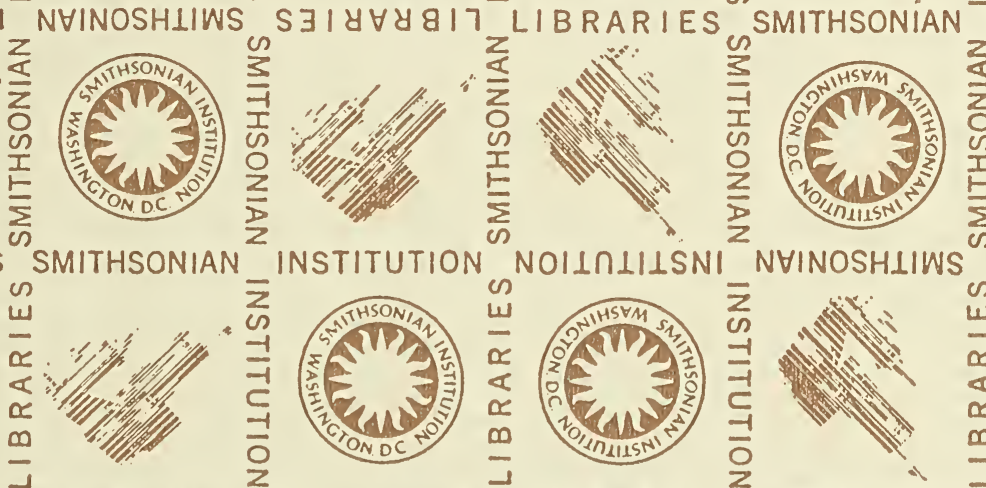

NHINOSHIIWS

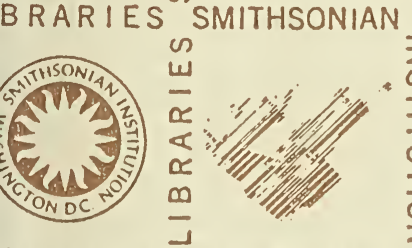

IINIILSNI NVINOSHIINS
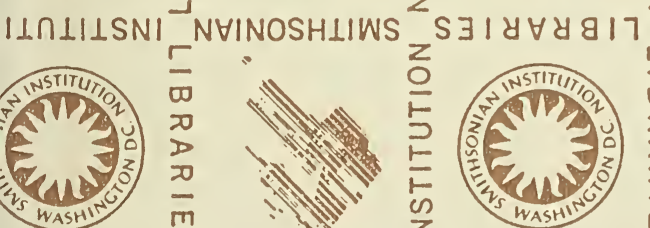

$\rightarrow$ I R

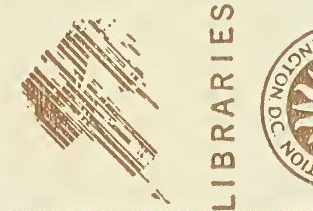

INST
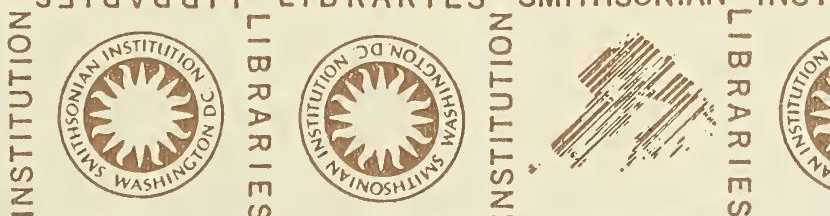

BRAR IES
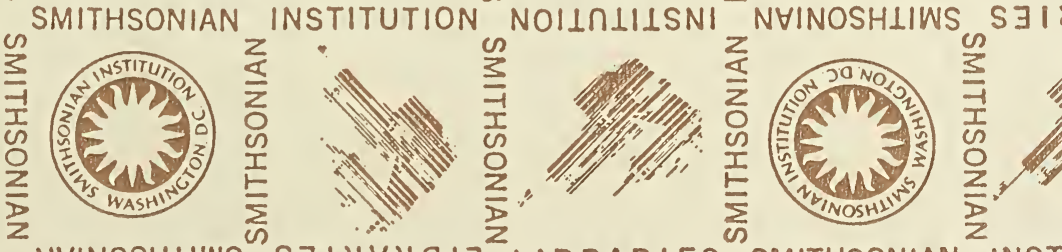

IINLILSNI NHINOSHLIWS

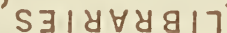

LIBRARIES SMITHSONIAN

INST 



$$
H
$$






\section{$F-5 / 8180$}
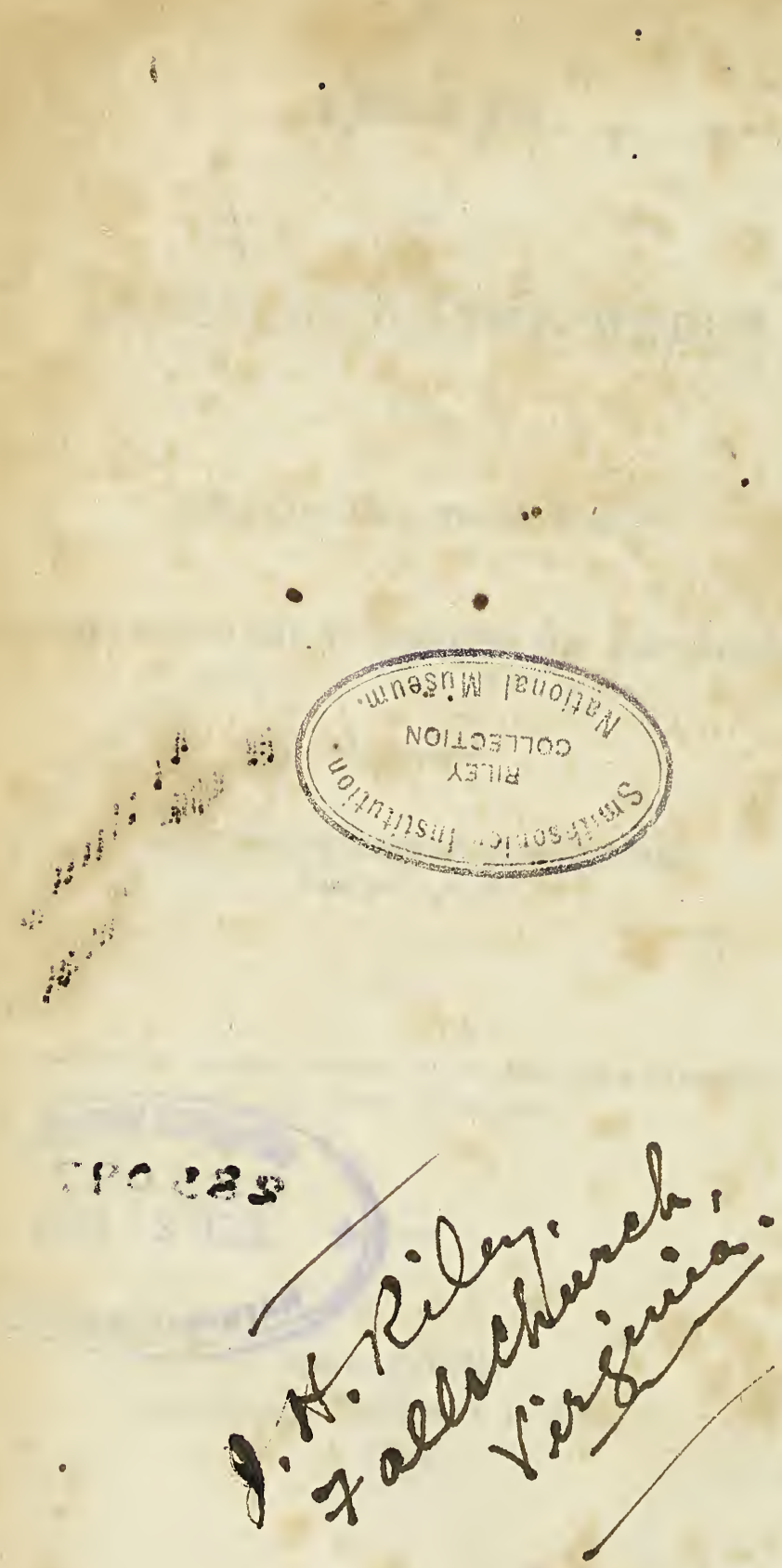
The Genera of North American Birds, and a Synopsis of the SPECIEs found within the territory of the UNITED States/; systematically arranged in Orders and Families. By Charles L. Bonaparte. Read January 24, 1826.

IT was the author's intention to ha rred the publication of the present Synopsis, as announced in the preface to the continuation of Wilson's Ornithology, until the appearance of the concluding volume of that work; when it might, with the attention which time would enable him to bestow upon it, be made more worthy of meeting the public eye. It having been suggested, however, that even in its present state, its publication might facilitate the study of the branch of Natural History to which it relates ; and moreover, thinkiug that it might contribute to the perfection of the future edition, he begs leave to submit it for the consideration of the Lyceum.

No species has been admitted to a place in the following Synopsis, that is not described in the standard work of Wilson, and adopted in our observations on the Nomenclature of . his Ornithology; or that has not been since discovered or ascertained by us to be actually an inhabitant of the United States. The latter will appear in our Natural History of the birds not given by that justly admired author. All other species stated to inhabit the United States, on whatever authority, we regard as apocryphal; and we have no hesitation in declaring, that the discoverer of a bird not noticed here, will render an important service to science by publishing an account of it.

The classification here adopted is that of a general system, the analysis of which we hope to publish shortly : although not entirely new, it in many respects deserves that title. The introduction of new appellations has indeed been avoided throughout, even when they would have been more appro- 
priate; for there can hardly be any new division proposed, for which a suitable name may not be found among the great number which already encumber the science. The names have, therefore, been selected from various authors, though the groups they represent do not in all cases exactly correspond.

We have endeavoured to dispose the species as nearly as possible in a natural series. We are, however, fully aware that organized beings cannot be arranged in a regular and continuous line, but that their relations with each other would be more accurately represented by lines radiating from different centres, uniting and crossing in various directions.

Notwithstanding this general intricacy of affinities, there re, however, several genera, families, and especially orders, that will admit of a disposition in a regular series, and yet remain in strict conformity to nature. It is obvious, for instance, that the ANSEREs must terminate the series of the feathered tribes (as the Cete that of the pilose), that the Grallar. should immediately precede them (occupying the relative position of the Bellue), then the Galline, (which may be compared to $P_{\text {ECORA }}$ ) and still ascending in the natural series, we arrive at the families of the Passerigalli and Columbini, which form an excellent link between Galline and Passeres, and thus connect our two subclasses.

I have separated the feathered tribes into two subclasses, represented by a character drawn from the relative insertion or absence of the hind toe. These divisions seem to be more consonant to nature, than those of land and water birds, the characters of which are not sufficiently precise, and are subject to many exceptions.

The only material change resulting from the adoption of these divisions, is the separation of the GALLIN $\approx$ from the artificial situation they formerly held in the more numerous subclass, in order to place them in our second division; and who will deny that Gaturine is more intimately allied to Grallat 
and Anseres, than to Passeres and Accipitres, notwithstanding the beautiful series of links by which they are connected with the latter?

Our first subclass is monogamous, whereas the second is chiefly polygamous. The first feed their young, which are born naked and with the eyes closed, and from their feeble and helpless nature are confined to the nest; while the offspring of the second division, are able to run from the nest as soon as hatched. This contrast proves the superiority of organization in the former; since it is well known, that those beings, which are most elevated in the scale of nature, require the greatest degree of parental care in their infancy.

The characters of the Orders, and of North American Families, are given in detail; and none are in any case again repeated under the Genera.

In the short specific phrases, we have endeavoured to include such essential and differential characters, as will clearly designate each species, not only from those of this country, but from all others known. Synonyms from all the principal authors were added, to enable the student to refer with readiness to all that has been published relative to the birds of this country; but as they would have occupied too much space in the valuable pages of the Annals of the Lyceum, they are for the present omitted; especially as many of the most important may be found in our Observations on the $\mathcal{N}_{0}$ menclature of Wilson's Ornithology. We have, therefore, only subjoined to each species, the name of the author whose appellation we adopt, together with a reference to the American Ornithology; and a select synonym only in those cases where we have unfortunately been compelled to give a new name to a species already known.

An analytical table, constructed without reference to foreign genera, is prefixed to the synopsis in order to facilitate the search after the genus to which any North American bird may belong. 
The following is a list of the publications we have consuit: ed, with the abbreviations under which they are quoted.

I._L_Linnè, Systema Naturæ. Editio duodecima Vindobonæ. 1767.

Briss.-Brisson, Ornithologia sive Synopsis methodica Avium. Parisiis. 1760.

Gm.-Gmelin, Linnè Systema Naturæ. Editio decima. tertia. Leipsic. 1788.

Lath.-Latham, Index Ornithologicus, sive Systema Ornithologiæ. Londini. 1790. and Supplement 1801.

Ill._-Illigeri Prodromus Systematis Mammalium et Avium. Berolini. 1811.

Cuv._Cuvier, Règne Animal. Paris. $181 \%$.

Vieillot, Histoire Naturelle des Oiseaux de 1'Amè. rique Septentrionale (incomplete work). Paris.

Vieill. 1807, \& the different articles on birds in the Nouveau Dictionnaire d'Histoire Naturelle of Deterville. Paris. 1816--1819.

Temminck, Manuel d'Ornithologie. Paris. 1520. Temm. $\{$ \& Temminck et Laugier, Nouveau Recueil de Planches coloriées d'Oiseaux. Paris 1820-25. (to pl. 360.)

Ranz.-Ranzani, Elementi di Zoologia. Bologna. 182123.*

Latr.-Latreille, Familles Naturelles du Règne Animal. Paris. 1825.

In addition to the above mentioned authors a few others will be occasionally quoted, as Savigny, Meyer, Lacépède, \&c.

* In this judicious compilation, the new zoological modifications are ably and critically discussed. Every good Italian must be grateful to Mr. Ranzani for his successful prosecution of this patriotic and arduous enter. prise, which has long been a desideratum. 
Viers of the Natural Families of the System adopted in the classification of the North American Birds.

Binds are vertebrated, warm-blooded, oviparous animals, formed for flying; breathing by lungs: lungs undivided, attached to the ribs, covered by a membrane perforated with large holes; heart bilocular and biauricular; a corneous edentate bill; skin feathered; two wings and two feet.

In the present state of the science, they form the second class of the first type of the animal kingdom.

\section{SUBCLASS I.}

Hind toe articulated on the same plane with the fore toes, and bearing on the ground its whole length; formed for grasping.

\section{ORDER I. ACCIPITRES.}

Feet ambulatory: bill hooked, with a cere : nails retractile. 1. Vulturini. Head naked.

2. RAPACES. Head feathered.

* Diurni. Eyes lateral. ** Nocturni. Eyes in front.

\section{ORDER II. PASSERES.}

Feet ambulatory, gressorial, or scansorial. TRIBE I. SCANSORES. Toes two before, and two behind.

$\$$ Anterior toes divided, or united only at base.

3. Psittacini. Bill hooked, with a cere: none of the tocs versatile.

4. Frugivori. Outer hind toe versatile, connected with the fore toes by a membrane.

5. Амphibol. Outer hind toe versatile, free.

* Bill ciliated. ** Bill not ciliated.

6. Sagittilingues. Bill straight; none of the toes versatile. 
$\oint \oint$ Anterior toes united to the first joint or beyond.

\%. Syndactyli. Bill straight, entire.

8. Serrati. Bill exceedingly large, curved, serrate.

TRIBE II. AMBULATORES. Toes three before, one behind.

$\oint$ Feet gressorial.

9. Dentriostres. Bill cultrate : tibiæ feathered.

10. Angulirostres. Bill subquadrangular, acuminate : tibix half naked.

$\oint \oint$ Feet ambulatory.

11. Gregarir. Bill robust, conic-acuminate, or cultrate, forming a sinus in the front feathers.

* Bill conic-acuminate. ** Bill cultrate.

12. Sericati. Bill short, depressed : gape very wide : wings and feet moderate.

13. Chelidones. Bill very short, depressed, slender : gape very wide : wings very long : feet remarkably short.

14. Canori. Bill moderate, more or less subulate: outer toe united at base to the middle one.

* Bill depressed. ** Bill robust, convex, compressed. *** Bill subcultrate. $* * * *$ Bill subulate.

15. Tenuirostres. Bill elongated, slender: tongue not extensible. * Anerpontes. ** Epopsides.

16. Anthomyzr. Bill elongated, very slender: tongue extensible.

17. Egithali. Bill short, hard, conic-subulate : hind toe and nail largest.

18. Passerini. Bill short, robust, conic.

19. Columbini. Bill vaulted: nostrils covered by a turgid membrane.

20. PASSERIGalli. Bill vaulted, no turgid membrane. 


\section{SUBCLASS 11 .}

Hind toe articulated higher on the tarsus than the fore toes, incapable of grasping, or wanting.

\section{ORDER III. GALLINE.}

Tarsi rounded, robust, rather short ; tibia wholly feathered: bill short, vaulted.

21. Gallinacer. Fore toes connected at base by a membrane. * Tarsi naked. $\quad * *$ Tarsi feathered.

22. Crypturi. Toes not connected by a membrane.

* Four toed. $\quad * *$ Three toed.

ORDER IV. GRALL死.

Tarsi rounded, slender, elongated; tibiæ almost always partly naked : bill generally elongated.

23. Struthiones. Feet two or three toed; toes divided: no quill feathers.

24. Pressinostres. Bill moderate, rather robust: hind toe wanting or very short.

25. Alectrides. Bill short, stout, subvaulted: toes four. some or all connected.

* Hind toe not touching the ground.

** Hind toe bearing on the ground.

26. Heronir. Bill elongated, stout, robust.

* Hind toe touching the ground only at tip.

** Hind toe bearing on the ground with several joints.

27. Falcati. Bill very long, arcuated: face naked: hind toe bearing on the ground nearly its whole length.

28. Limicolæ. Bill elongated, slender: hind toe hardly touching the ground, or wanting.

29. Macrodactyl. Bill short or moderate: toes divided. very long: hind toe bearing on the first joint.

$$
\text { * Toes simple. * Toes pinnated. }
$$

VOL. II. 
30. Pindatipedes. Bill straight, slender : toes lobated.

31. HyGRoBATE. Bill elongated: toes semipalmated.

\section{ORDER V. ANSERES.}

Tarsi compressed, abbreviated : tibiæ almost always partly naked : toes palmated.

32. LongIPENNES. Toes palmated; hind toe free, or wanting: bill toothless: wings long, acute.

* Nostrils immarginate. ** Nostrils tubular.

33. Lameicosodentati. Toes palmated; hind toe free: bill toothed.

34. Steganopodes. Toes four, all connected by a broad membrane.

* Bill entire. ** Bill serrated.

35. Lobipedes. Toes lobated.

36. Pygopodes. Toes palmated; hind toe free or wanting: bill toothless : wings short, rounded.

* Four toed.

** Three toed.

3\%. Inpennes. Toes palmated; hind toe free, directed forward: no quills nor tail. 


\section{ANALYTICAL TABLE}

OF THE NORTH AMERICAN GENER,

\section{ORDER ACCIPITRES.}

Family Vulturini.

Genus 1. C Athartes.

Family Rapaces.

2. Falco. Eyes lateral : cere obvious.

3. Strix. Eyes in front: cere concealed,

\section{ORDER PASSERES.}

TRIBE I. SCANSORES.

Family Psittacini.

4. Psitucucus.

Family Amphibol.

5. Coccrzus.

Family Sagittilingues.

f. Picus.

TRIBE II. AMBULATORES.

$\S$ Feet gressorial.

Family Angulirostres.

\%. Alcedo.

§§ Feet ambulatory.

Family Gregarir.

\$. Sturnus. Bill straight, depressed, obtuse; edges vertical.

9. Icterus. Bill straight, compressed, acute; edges inflexed.

10. Quiscalus. Bill cultrate, bare.

11. Corvus. Bill cultrate, covered at base with setareous incumbent feathers. 
Family Sericati.

Genus 12. Bonisycilla.

\section{Family Chelidones.}

13. Caprimulgus. Fore toes connected by a membrane; hind toe versatile : tail of ten feathers.

14. Crpselus. Toes divided; hind toe versatile: tail of ten feathers.

15. Hirundo. Hind toe not versatile: tail of twelve feathers.

Family Canori.

16. Muscicapa. Bill depressed, notched, with basal bristles.

17. Icteria. Bill robust, compressed, curved, entire.

18. Vireo. Bill compressed, notched, with basal bristles.

19. Lanuus. Bill curved, with a sharp tooth each side near the tip.

20. Myгтнеra. Bill, at base higher than broad, notched : tarsi elongated.

21. Turdus. Bill rounded-cultrate, at base broader than high.

22. Sylvia. Bill subulate, at base higher than broad.

23. Saxicola. Bill deeply cleft, subulate, at base broader than high and carinated.

24. Antrus. Bill subulate, notched: hind nail long, straightish: two of the scapularies as long as the primaries.

25. Regulus Bill short, subulate, notched, covered at base by a small, rigid, decompound, incumbent feather.

26. Troglodytes. Bill rather elongated, very slender, curved, entire.

Family Tenuirostres.

2\%. Certhis. Bill curved : tail feathers rigid, pointed. 
of the United States.

Genus 28. Sitra. Bill conic-subulate.

Family Anthomyzr.

29. Trochilus.

Family Egrthali.

30. Parus.

Family Passerini.

31. Alauda. Bill conic-attenuated, entire : hind nail long, straightish.

32. Embriza. Upper mandible coarctate, narrower than the lower.

33. Tanagra Bill at base trigonal and somewhat depressed, slightly curved at tip: outer toe united at base to the middle one.

34. Fringinas. Bill perfectly conic, acute ; upper mandible wider than the lower.

35. Prranula. Bill conic-convex, turgid; upper mandible much curved at tip.

36. Loxia. Mandibles crossing each other.

Family Columbint.

3\%. Columba.

\section{ORDER GALILINAE.}

Family Gallinacer.

38. Meleagris. Bill with a cere-like membrane : tarsi naked.

39. Perdix. Bill bare: tarsi naked.

40. Tetrao Bill covered at base with feathers: tarsi feathered.

\section{ORDER GRALLE.}

Family Pressirostres.

41. Charaprius Bill short, rounded, obtuse, some what turgid at tip: hind toe wanting or exceedingly small. 
Genus 42. Strepsilas. Bill oblong-conic: hind toe touching the ground at tip.

43. H年a topus. Bill rather long, compressed at tip : hind toe wanting.

Family Herodir.

44. Grus Hind toe touching the ground only at tip.

45. Ardea Hind toe bearing on the ground with several joints.

\section{Family Falcati.}

46. Tantalus Upper mandible not furrowed, notched. 47. IBIs. Upper mandible furrowed, entire.

Family Limicole.

48. Numenius. Bill very long, arcuated.

49. Tring a. Bill moderate, straight or slightly curved; point depressed, soft and obtuse.

50. Totanus. Bill moderate, straight or slightly recurved; point compressed, solid and sharp.

51. Himantopus. Legs extremely long, slender, flexible; toes three.

52. Limosa. Bill very long, slightly recurved, soft, and obtuse at tip.

53. Scolopax. Bill long, straight, compressed, soft, elevated at base: point obtuse.

Family MACRODACTYLI.

54. Rallus. Toes simple: forehead feathered.

55. Gallinula Toes simple: forehead bald.

56. Fulica. Toes pinnated: forehead bald.

Family Pinnatipedes.

57. Phalaropus.

Family Hygrobate.

58. Recurvirostra. Bill subulate, recurved.

59. Platalea. Bill flattened and orbicular at the point. 60. Phonicoprerus. Bill large, toothed, bent as if broken. 


\section{ORDER ANSERES.}

\section{Family Longipennes. \\ * Nostrils immarginate.}

Genus 61. Rhincopa Lower mandible much longer than the upper, truncated.

62. STERA Bill subulate, straightish, compressed, acute.

63. L:srus. Upper mandible hooked, without a cere : lower gibbous below the point.

64. Lestris. Upper mandible hooked, covered at base by a cere : lower gibbous below the point. ** Nostrils tubular.

65. Procellarta Hind toe only a sharp nail. 66. Diomedea. Feet three-toed; no hind nail.

Family Lamellosodentati.

67. Anas. Bill depressed, obtuse; teeth lamelliform.

68. Mergus. Bill slender, hooked; teeth subulate.

Family Steganopodes.

* Bill entire.

69. Penecanus. Bill much depressed.

70. Phalacrocorax. Bill compressed, hooked, not seamed above: tibiæ wholly feathered.

91. Tachypetes. Bill compressed, hooked, seamed above : tibixe wholly feathered.

* Bill serraied.

72. Sula. Bill stout, straight, compressed; face naked.

73. Рhanton. Bill cultrate: face feathered.

74. Protus, Bill subulate: face naked. 
Family LobIPEDES.

Genus 75. Podoa. Bill serrated.

76. Podiceps. Bill entire.

Family Pygopodes.

* Feet four-toed.

7\%. Colymbus.

$$
\text { ** Feet three-toed. }
$$

\%8. URIA. Bill nearly straight, pointed: nostrils half closed by a feathered membrane.

79. Mormox Bill curved, exceedingly compressed, higher than long: nostrils half closed by a naked membrane.

S0. Alca. Bill curved, exceedingly compressed, longer than high: nostrils half closed by a feathered membrane. 


\title{
THE GENERA
}

OF

\section{NORTH AMERICAN BIRDS,}

\author{
AND
}

A SYNOPSIS OF THE SPECIES FOUND IN THE UNITED STATES,

\section{ORDER I. ACCIPITRES.}

Accipitres, L. Gm. Lath. Cuv. Vieill. Raptatores, Ill. Rapaces, Temm. Ranz. Latr.

BiLL short, robust, compressed; upper mandible hooked, covered at base with a cere; lower shorter, generally obtuse: nostrils patulous, situated in the cere: tongue generally fleshy, thick, obtuse. FeEt strong, muscular; tibiæ fleshy, wholly feathered; tarsi rounded, generally short or moderate; toes, three before and one behind, divided, or connected at base by a membrane; sole rough; nails strong, compressed, incurved, acute, retractile. NECK short : body thick and heavy. Tall of twelve or fourteen feathers.

Female larger and more powerful. Young at first covered with down. Moult annually.

Rapacious : hunting quadrupeds, birds, reptiles, fishes, and insects, or feeding on dead bodies. Patient of hunger, and hardly experiencing thirst. Vision acute. Monogamous: nestling in high trees, rocks, and buildings; laying about four eggs; female only incubating. Flesh not esteemed as food. Analogous to Feræ in Mammalia,

VoL. II. 


\section{FAMILY I. VULTURINI.}

Vulturini, Mll. Vieill. Latr. Accipitres diurni, Cuv.

Rapaces diurni, Ranz.

HEAD and part of the neck naked, former often carunculate; generally a collar of feathers round the neck. Eyes not sunk deep. Crop prominent, naked or woolly. FEET naked; tarsus shorter than the middle toe; outer toes connected at base by a membrane; nails not much incurved, rather obtuse, hardly retractile. Wings elongated, subacuminate.

Young with the head entirely covered with down.

Gregarious ; cowardly ; voracious ; feed on carcasses and filth, very serviceable in hot climates, and protected by law in the cities of the southern states: sometimes prey upon small living animals, reptiles, and birds' eggs. Diffuse a disagreeable odour. Lay but two eggs. Disgorge food from the crop to feed their young.

\section{CATHARTES.}

Vultur, L. Briss. Gm. Lath. Cuv. Sarcoramphus, Duméril. Neophron, Savigny. Cathartes, Ill. Temm. Ranz.

Vultur, Gypagus, Catharista, Vieill.

Bill elongated, straight at base; upper mandible covered to the middle by the cere; nostrils medial, approximate, oval, pervious, naked ; tongue canaliculate, edges serrate. HEaD elongated, depressed, rugose. TARsus rather slender; lateral toes equal; middle one much the longest; inner free; hind toe shortest. First primary rather short; third and fourth longest.

Inhabit both continents.

SUBGENUS CATHARTES.

Bill robust : tail of twelve feathers. Peculiar to America.

1. Cathartes Californianus, Ranz. Blackish; feathers of the collar and breast lanceolate; wings reaching much beyond the tail.

Vultur californianus, Lath. Cathartes vulturinus, Temm. 
Inhabits the territory of the United States beyond the Rocky Mountains; and California.

2. Cathartes Gryphus, Temm. Black; wings varied with white, not reaching beyond the tail; head carunculated.

Female destitute of the caruncle. Young entirely brown.

Vultur gryphus, L. Gypagus griffus, Vieill.

Inhabits the south-western territory of the United States; Mexico, and especially the Andes of Chili and Peru.

3. Сатнaktes papa, Ill. Reddish-white; wings and tail black; nostrils carunculated.

Young dark bluish; belly and sides of the rump whitish.

Vultur papa, L. Gypagus papa, Vieill.

Inhabits the warmest parts of America : appears occasionally in Florida during summer.

4. Cathartes aura, Ill. Black; neck feathered equally all round; wings not reaching beyond the tail; tail rounded; nostrils oval.

Young brown; wing-coverts and secondaries spotted with white.

Turkey Buzzard or Turkey Vulture, Vultur aura, Wils. Am. Orn. ix. p. 95. pl. 75. fig. 1 .

Inhabits throughout the Union, the West Indies and South America; most numerous in the southern states; breeds and winters in New-Jersey; not farther north.

5. Cathartes jota, Nob. Black; neck more feathered above. than below; wings not reaching beyond the tail ; tail slightly emarginate; nostrils linear-oval.

Young entirely brown.

Black Vulture or Carrion Crow, Vultur atratus, Wils. $\mathcal{A}$. Orn. ix. p. 104.pl. 75. fig. 2. Vultur jota, Molina.

Inhabits the continent of America as far north as North Carolina. Forms the transition from the American, to the European subgenus, Percnopterus. 


\section{FAMILY II. RAPACES.}

Nocturni, Accipitrini, Ill. Accipitres diurni, Accipitres noeturni, Cuv. Vulturini, Accipitrini, Egolii, Gypaëti, Vieill. Rapaces diurni, Rapaces nocturni, Ranz.

Vulturini, Accipitrini, OEgolii, Latr.

Head thickly covered with feathers. Tarsus longer than the middle toe; nails strong, sharp, much incurved, very retractile. TAIL of twelve feathers.

Solitary, or in pairs during the breeding season only. Feed on living animals, unless compelled by hunger; seize their prey and carry it in their talons. Lay the food before their young. Expel them from the nest when full-fledged.

\section{FALCO.}

Falco, L. Gm. Lath. Ill. Cuv. Temm. Ranz, Aquila, Accipiter, Briss. Aquila, Falco, Brehm. Daptrius, Zlbycter, Polyborus, Aquila, Haliaëtos, Pandion, Circaëtos, Circus, Buteo, Milvus, Elanus (since. Elanoïdes), Ictinia, Falcos Tinnunculus (since united to Falco), Physeta (since HerpeGotheres,) Harpyia, Spizaëtos, Asturina, Sparvius, Vieill.

BiLL robust ; cere short, coloured, obvious; lower mandible obliquely rounded at tip : nostrils situated at the edge of the cere, Eyss lateral, sunk deep in the head. FEET strong; tarsus of middling length.

Female differing often in colour, and much larger than the male. Young more variegated by spots and lines than the adults : vary greatly from age, and do not receive their perfect plumage until the third or fourth year.

Diurnal. Fly high and soar beyond the reach of vision. Obtain their prey by violence, pouncing upon it sometimes from a great height.

\$1. Bill elongated, straight at base.

Aquila, Briss. Brehm. Aigles proprenent dits, Temm.

Bill with an obtuse lobe each side: head feathers long, 
acuminated. Female similar in colour, though larger than the male.

\section{SUBGENUS 1. AQUILA.}

\section{Aquila, Briss. Meyer. Cuv. Vieill.}

Bill very robust, angular above; cere subhispid; nostrils rounded-elliptical, transverse. Feet very robust; tarsi feather-o ed to the toes; middle toe considerably longest, connected at base by a membrane with the outer; nails large, very sharp and incurved, the middle one pectinated on the inner side. Wings elongated; first primary very short; fourth longest.

The most powerful of the genus, surpassing all others in courage and strength, carrying off even large animals. Inhabit mountainous districts. Sight keen. Sense of smelling imperfect.

6. Falco fulvus, L. Dusky; cere and toes yellow; tail rounded, reaching beyond the wings; three scales only on the last joint of each toe.

Adult : tail fasciated with blackish.

Young : tail white at base, blackish towards the tip.

Ring-tailed Eagle, Falco fulvus, Wils. Am. Orn. vii. p. 13. pl. 55. fig. 1. young.

Inhabits the north, or on the highest mountains of both continents : rare in America.

\section{SUBGENUS II. HALIAËTOS.}

Haliä̈tos, Savigny. Cuv. Vieill.

Bill very robust, convex above; cere subhispid; nostrils Junulated, transverse. Tarsi half feathered, scutellate; toes divided to the base; outer subversatile; nails subequal, beneath canaliculated; the middle one with a deep channel, and the inner side pectinated. Wings elongated; first primary very short; fourth longest.

Chiefly piscivorous; keep generally near the sea-shores, lakes and rivers: their great size and strength enable them to vanquish large animals, birds, and mammalia: participa- 
ting in the habits of the true Eagles: connecting Aquila to Pandion.

7. Falco leucocephalus, L. Brown; head and tail white; tail reaching beyond the wings; bill, feet, and irides, pale yellow.

Young spotted irregularly with darker and paler brown; bill black; irides light brown.

Bald Eagle, Falco leucocephalus, Wils. Am. Orn. iv. p. 89. pl. 36. adult, and Sea Eagle, Falco ossifragus vii. p. 16. pl. 55. fig. 2. young.

Inhabits the northern regions of both continents, chiefly near the sea and other waters; much more frequent in America.

SUBGENUS III. PANDION.

Pandion, Savigny. Cuv. Vieill.

Bill rounded above; cere hispid; nostrils lunulated, oblique, membranaceous on the superior margin. Tarsi naked, reticulated, scales rough; toes divided to the base, the outer versatile; nails equal, rounded beneath, the middle one not pectinated. Wings elongated; first primary equal to the third; second longest.

Cowardly: piscivorous: live near waters, from which, when frozen, they retire to a warmer climate : may be trained to fish for man. Seize their prey in their claws at the surface of the water, or plunge for it : seldom hunt birds. In consequence of their true Falcon-like wings, sail beautifully, and with much ease in the air.

8. Falco halietus, L. Blackish, white beneath; cere and feet bluish.

Fish Hawk, Falco halioetus, Wils. Am. Orn. v. p. 13. pl. 5. fig. 1 .

Inhabits almost every part of the globe near waters; much more common in North America than in Europe. 


\section{Bill curved from the base.}

Accipiter Briss. Falco, Brehm.

* Bill with a sharp tooth each side.

SUBGENUS IV. FALCO.

Falco, Bechstein. Falco, Hierofalco, Cuv.

Faucons proprement dits, Temm. Falco, Tinnunculus, Vieill.

Bill short, curved from the base; lateral tooth closing into an emargination of the lower mandible; cere very short, naked : nostrils rounded, with a central tubercle. Feet strong; tarsi moderate; toes strong, elongated, the anterior connected at base by a membrane; nails long, sharp, incurved. Wings elongated ; first and third primaries equal, second longest; first and second with an abrupt emargination on the inner web near the extremity.

Female about a third larger, differing in colour from the adult male.

Bold : feed chiefly on small birds; seize their prey on the wing : flight vigorous : readily tamed, hence called noble!

$\dagger$ Wings reaching to the tip of the tail : tarsi reticulated.

9. Falco Peregrints, Gm. Blackish; beneath white, spotted with blackish; cheeks with a dilated black spot; middle toe as long as the tarsus; inner web of the first primary only, abruptly narrowed at tip.

Great-footed Hawk, Falco peregrinus, Wils. Am. Orn. ix. p. 120. pl. 76 .

Inhabits the northern portion of both continents; but more common in Europe.

t+ Wings not reaching to the tip of the taib: tarsi scutellated.

10. Falco sparverius, L. Rufous, beneath paler, spotted with black; seven black spots around the head.

Male : upper part of the head, crown excepted, and wingcoverts slate-blue; tail with a single subterminal band.

Female and Young more fasciated and spotted; wing. coverts rufous; tail fasciated. 
American Sparrow-Hawk, Falco sparverius, Wils. Am. Orn. ii.p. 11\% pl. 16. fig. 1. female, and iv. p. 5\% pl. 32. fig. 2. male.

Inhabits throughout North and South America, except in high northern latitudes: wintering in the southern states.

11. Falco columbarius, L. Dusky; beneath whitish, with blackish stripes; tail with four narrow white bands.

Pigeon Hawk, Falco columbarius, Wils. Am. Orn. ii. p. 10\%. pl. $1 \therefore$ fig. 3.

Inhabits the south of the United States; extending its migrations as far north as Hudson's Bay.

*** Bill with an obtuse lobe each side.

SUBGENUS V. ASTUR.

Astur, Bechst. Cuv. Dodalion, Savigny. Autours, Temm. Accipiter, (afterwards Sparvius), Vieill.

Bill strong; lobe of the upper mandible well defined: nostrils rounded or somewhat oval and oblique. Tarsi rather elongated, scutellated; middle toe much longer than the lateral; outer connected at base by a membrane, shorter than the inner: nails long, much incurved, very acute. Wings short; first primary considerably shorter than the second; fourth longest.

Female similar in colour, but a full third larger than the male.

Bold; sanguinary; skimming the earth with great rapidity of flight; seize their prey upon the wing, but never falling upon it from on high, nor soaring into the elevated regions of the atmosphere; and only describing wide circles in the air in the season of their loves.

$\dagger$ Tarsi rather short and robust, (Astures, auct.)

12. Falco palumbarius, L. Blackish; eyebrows whitish; tail fasciated with paler; cere livid yellow. 
Young dusky brown skirted with ferruginous; beneath white lineated with brown; tail with four blackish bands, tipped with white; length more than one foot and a half.

Ash-coloured or Black-capped Hawk, Falco atricapillus. Wils. Am. Orn. vi.p. 80.pl. 5.fig.3. very old; and Young Goshawk, Falco palumbarius, nob. Am. Orn. 2. pl. 10. fig. 1. young.

Inhabits the north of both continents ; more rare in America.

13. Falco Pennsylvanicus, Wils. Dark brown; head streaked with whitish; beneath white thickly spotted on the breast with brown arrow heads; tail short, black, with two bars of white and tipped with whitish; cere and feet yellow.

Broad-winged Hawk, Falco pennsylvanicus, (F. latissimus in Mr. Ord's reprint) Wils. Am. Orn. vi. p. 92. pl. 54. fig. 1. male.

Inhabits the United States, exceedingly rare.

$$
\text { t† Tarsilong, slender, smooth. }
$$

Accipitres, Sparvii, Eperviers, auct.

14. Facco vecox, Wils. (1.) Slate colour, beneath white, barred with ferruginous; tail with four broad bands of black, and tipped with whitish; cere dull green; irides and feet orange.

Young dark brown skirted with ferruginous ; beneath white with oblong ferruginous spots; length about one foot.

Slate-coloured Hawk, Falco pennsylvanicus, W'ls. sim. Orn. vi.p. 13. pl. 46. fig. 1. adult male; and Sharp-shinned Hawk, Falco velox, Wils. Am. Orn. v. p. 116. pl. 45. fig. 1. young female.

Inhabits all parts of North America : common in NewJersey and Pennsylvania, though rare in the time of Wilson.

VoL. II. 
SUBGENUS VI. ICTINIA.

Ictinia, Vieill. Milans, Temm. Buteo, Cuv.

Bill short, narrowed above; upper mandible angularly lobed; lower distinctly notched; cere glabrous: nostrils rounded. Tarsi short, slender, scutellated, feathered for a short space; outer toe connected at base by a membrane; nails short, not very acute. Wings greatly elongated; reaching much beyond the tail ; third primary longest. Tail even.

Bold : feed on small birds, reptiles, \&c. but chiefly on insects. Sail in easy circles at a considerable height in the air. Intermediate between Falco and Milvus, somewhat allied to Buteo.

15. Falco Plumbeus, Gm. Blackish-ash; head, neck, and beneath, considerably paler; tail black; cere black; feet and irides red.

Young bluish-black; head and beneath whitish, spotted with bluish-brown; tail with three white bands beneath; cere yellowish.

Mississippi Kite, Falco mississipiensis, Wils. Am. Orn. ïi. p. 80. pl. 25 . fig. 1. adult male.

Inhabits the Southern States, South America, and Mexico; common on the Mississippi near Natchez.

SUBGENUS VII. ELANUS.

Elanus, Savigny, Cuv. Leach. Milans, Bechst.

Elanoides, Vieill. Milans, Temm.

Bill 'of middling strength, cleft beyond the eyes, much compressed, rounded above ; lobe of the upper mandible obtuse; cere villous : nostrils oval. Tarsi short, thick, reticulated, half feathered in front; toes cleft to the base; nails large, acute. Wings greatly elongated: first and third primaries subequal; first and second strongly. emarginate within, the latter longest.

Timorous, with a comparatively small and weak bill, 
though not so much so as the true kites (Milvus.) Like these, excel in flight, describing graceful circles in the air with a broad expanse of wing. Seldom attempt to take their prey flying, but pounce upon it while it is at rest. Feed on small birds, insects, and particularly reptiles, contenting themselves with dead animal substances.

16. Falco melanopterus, Daudin. Bluish-gray, beneath white; wing-coverts black; tail even.

Black-winged Hawk, Falco melanopterus, nob. Am. Orn. ii. pl. 11. fig.1. adult female.

Inhabits the southern states; also Africa and South America, the south-western part of Asia, the island of Java, and probably India.

17. Falco furcatus, L. White; back, wings and tail, glossy black; tail deeply forked.

Swallow-tailed Hawk, Falco furcatus, Wils Am. Orn. vi. p. 70. pl. 51. fig.2. adult male.

Inhabits common during summer in the southern states; Mexico and South America; exceedingly rare, and only astray in Pennsylvania and farther north.

\section{SUBGENUS VIII. BUTEO.}

Buteo, Bechst. Cuv. Vieill. Buses, Temm.

Bill short, moderately compressed, rather weak; uppei' mandible rounded above, terminating in a long hook, lobe obtuse ; sides of the lower mandible bent inwards ; cere short; nostrils rather large, nearly round; lores almost covered by short bristles: head rather large; neck thick and short; body thick. Tarsus short, thick, scutellated, partially or entirely feathered; outer toes connected at base by a membrane; nails acute, rather weak, those of the inner and hind toe nearly equal and largest. Wings elongated; four first primaries abruptly attenuated at tip on the inner web; the first very short, the fourth longest. Tail moderate, even.

Female larger, but similar in colour. Young widely dif- 
ferent from the adults. By their large head, heavy body, humble flight, and inferior boldness, they in a slight degree resemble Owls. Feed on young rabbits, mice, rats, reptiles, insects, and small birds, which they watch for from their perch, as they cannot successfully chase them on the wing.

$\dagger$ Tarsifeathered, to the toes.

18. Falco tagopus, L. Varied with pale ochre and blackish; a blackish belt on the belly; tail white, black towards the tip, at tip pure white.

Rough-legged Falcon, Falco lagopus, Wils. Am. Orn. iv. p. 59. pl. 33. fig. 1 .

Inhabits the northern parts of both continents: in Pennsylvania only during winter.

19. Falco sancti-johannis, Gm. Black; white round the eye; tail rounded, with narrow bands of pure white, and tipped with dull white.

Young varied with white, brown, and ferruginous.

Black Hawk, Falco niger, (Falco sancti-johannis? in Mr. Ord's reprint) Wils. Am. Orn. vi. p. 82. pl. 53. fig. 1. adult. Id. variety vi. p. 84. pl. 55. fig. 2. young.

Inhabits North America : winters in Pennsylvania, rare.

i† Tarsi partly feathered.

20. Falco boreacrs. Gm. (2.) Dusky; beneath whitish, with blackish hastate spots.

Adult, tail ferruginous, with a black subterminal band.

Young, tail dusky, with several narrow blackish bands.

Red-tailed Hawk, ralco borealis, Wils. Am. Orn. vi. p. 75. pl.52. fig.1. adult; and American Buzzard, or White-breasted Hawk, Falco leverianus, vi. p. 7\%. pl. 52. fig.2. young.

Inhabits throughout North America; common; resident. SUBGENUS IX. CIRCUS.

Circus, Bechst. Lacépède. Vieill. Busards, Temm.

Bịll much compressed, terminating in a long and acute 
hook; lobe strongly marked; edges of the lower mandible inflexed; cere not much extended, more or less pilose; nostrils oblong, transverse, covered in part by the hair; lores pilose: head depressed: body slender. Tarsus elongated, slender, scutellated, feathered for a short space : toes rather long, slender; outer toes connected at base : nails subequal, slender, much incurved, extremely sharp. Wings elongated; first primary shorter than the fifth; third and fourth longest. Tail long, nearly even.

Female and young differing considerably in colour from the male; often with a kind of collar of small rigid feathers surrounding the face, as in Owls. Plumage changing extraordinarily from age.

Bold : somewhat agile; flight graceful; in these respects superior to the Buteones, but inferior to the true Falcons. Do not chase well on the wing. Feed on mice, reptiles, fishes, young birds, and insects. Dwell near marshes and ponds. Build amongst marsh plants.

21. Falco hyemalis, Gm. No collar round the face; wings when closed reaching but little beyond the middle of the tail.

Adult brown skirted with ferruginous; head, neck, tail coverts and beneath, white, spotted with brown; tail barred alternately with dark and light brown.

Young brown and ferruginous; beneath rusty, varied with black and white; wings and tail black, the former spotted, the latter crossed by five bands, and tipped with white.

Winter Falcon, Falco hyemalis, Wils. Am. Orn. iv. p. 73. pl. 35. fig. 1. adult male; and Red-shouldered Hawk, Falco lineatus, Id. vi.p. 86. pl. 53. fig.3. young male.

Inhabits North America: rather common in Pennsylvania during winter.

22. Falco cyaneus, L. A collar round the face; wings 
reaching to three fourths the length of the tail, which is two and a half inches longer; third and fourth primaries equal.*

Adult male bluish grey; rump, inner web of the quill feathers, and beneath pure white; primaries black at the end.

Female and young chocolate brown; rump white; beneath risty; wings and tail on the under side, and two middle tail feathers also above, banded with black and white; lateral with blackish and rusty.

Marsh Hawk, Falco uliginosus, Wils. Am. Orn. vi. p. 67. pl. 51. fig. 1. young female; and nob. Am. Orn. ii. pl. 11. fig. 1. adult male.

Inhabits both continents. The young only are common in Pennsylvania and the northern parts of this continent, whence they migrate in winter to the south.

\section{STRIX.}

Strix, L. Briss. Gm. Lath. Ill. Cuv. Vieill. Temm. Ranz. Asio, Briss. Surnia, Bubo, Strix, Duméril.

Noctua, Scops, Bubo, Syrnium, Strix, Savigny.

Bill very short, cleft to the eyes, compressed, much curved; upper mandible rounded above, dilated on the margins, entire, terminating in an acute hook; cere small, soft, concealed by incumbent setaceous feathers; lower mandible notched, obtuse : nostrils perforated on the anterior edge of the cere, rounded, open, concealed by the porrect bristles: tongue thick, fleshy, somewhat canaliculated, papillous at base, emarginate at tip : eyes very large, directed forwards, with a nictitating membrane; orbits large, surrounded by long, slender, radiating feathers anteriorly almost covering the bill, and posteriorly concealing the ears: head large; face large, surrounded by a collar of small rigid elevated feathers : body generally thick, short, and heavy. TARSI generally short

* By these characters, ornithologists will perceive that F. uliginosus, Wils. is the young of F. cyaneus, and not of F. cineraceus. 
and covered with feathers; toes entirely divided; the outer versatile; hind toe shortest; nails strong, very sharp, re markably retractile. WINGs ample, subacute; first primary short, second a little shorter than the third which is longest: first three primaries generally with loose recurved barbs on the outer edge.

Young with a darker face, so as to appear masked; but after the first moult resembling the adults.

Solitary: nocturnal: hunt during the evening and night, - (with the exception of a few species which are diurnal) and see well in the dark. Eyes resplendent, pupil very large, contractile; dazzled by the light of day; moving awkwardly when exposed to it: hearing acute: feathers soft and loose; fly short distances without noise, and pounce upon their prey unexpectedly; feed on small birds, mice, bats, and insects, chiefly nocturnal lepidoptera; swallow their prey alive, and cast up the indigestible portions in small pellets; voice disagreeable, and believed by the superstitious to be of bad augury; breed in fissures of rocks, or in holes of old trees, Eggs from two to six. Analogous to the mammiferous genus Felis.

Spread all over the globe.

\section{\$1. Bill curved from the base.} SUBGENUS I. SURNIA.

Surni , Dumiril. Noctua, Scops, Syrnium, Cuv.

Opening of the ears oval and of moderate size, not operculated; disk of slender feathers, rather small and not remarkably distinct.

Approaching nearer to Falco than any other subgenus.

$$
\uparrow \text { Head without tufts of feathers (Noctua, Cuv.) }
$$

Feathered to the claws; quill feathers with the outer webs not recurved or loose at their tips. Tail reaching beyond the wings. The North American species are, all diurnal.

23. Strix FUNeReA, Gm. Blackish-brown, thickly spotted 
with white; beneath barred with white and brown; tail with several narrow white bands, cuneiform, reaching three inches beyond the wings; feet thickly covered with long feathers; bill yellow:

Hawk Owl, Strix hudsonia, Wils. Am. Orn. vi.p. 64. pl. 50 . fig. 6.

Inhabits the north of both continents : extremely rare, and only in cold winters as far south as Pennsylvania.

24. Strix nyctea, L. White, more or less spotted and barred with dusky according to sex and age; tail rounded, reaching but little beyond the wings; feet thickly covered with long feathers; bill black.

Snow Owl, Strix nyctea, Wils. Am. Orn. iv. p. 53. pl. 32. fig. 1. male.

Inhabits the north of both continents, whence it descends during winter to the more temperate regions, farther to the south in America than in Europe; not uncommon.

25. Strix cunicularia, Molina. (3.) Cinnamon-grey spotted with whitish; beneath white, spotted with cinnamon-brown; tail even, reaching but little beyond the wings; feet covered with short scattered bristles.

Burrowing Owl, Strix cunicularia, nob. Am. Orn. i. p. 68. pl. \% fig. 2.

Inhabits near the Rocky Mountains ; common : found also in South America

†† Head with erectile tufts of feathers (Scops, Bubo, Cuv.)

Nocturnal.

26. Strix asio, L. Dark brown (young tawny red) mottled with black, pale brown and ash; wings spotted with white; beneath white, mottled with black and brown; tail even, reaching to the tip of the wings; feet thickly covered with short feathers nearly to the claws.

Mottled Owl, Strix novia, Wils. Am. Orn. iii. p. 16. pl. 19. fig.1. adult, and Red Owl, Strix asio, id.v.p. 83. pl. 42. fig. 1. young. 
Inhabits North, and probably South America, as we strongly suspect Strix choliba, Vieill., a species taken from D'Azara, to be the present. Common in Pennsylvania and New Jersey in the autumn : retiring to the north in summer.

\section{SUBGENUS II. ULULA.}

Bubo, Syrnium, Sav., Otus, Ulula, Bubo Syrnium Cuv.

Conch of the ear vèry large, extended semicircularly from the bill to the top of the head, with a membranaceous operculum; disk of slender feathers well marked and perfect; feet thickly covered to the claws with short feathers. Nocturnal.

- † Head tufted. (Bubo, Otus, Cuv.)

27. Strix virginiana, Gm. (4.) Mottled; primaries and tail feathers banded with black and dusky; ${ }^{*}$ auricular conch restricted; wings not reaching to the tip of the tail: very large.

Great horned Oul, Strix virginiana, Wils. Am. Orn. vi. p. 52. pl. 50. fig. 1 .

Inhabits more or less common throughout America, principally in deep swampy woods: connects admirably the two subgenera Surnia and Ulula.

28. Strix orus, L. Mottled; primaries banded with ferruginous; tufts long; wings reaching beyond the tail.

Long-eared Owl, Strix otus, Wils. Am. Orn. vi. p. 73. pl. $51 \cdot$ fig. 3.

Inhabits both continents; common in Pennsylvania, especially in the autumn : resident.

29. Strix вrachyotos, Gm. Whitish-ferruginous, spottéd with dark brown; tufts short, inconspicuous; wings reaching to the tip of the tail.

Female more intensely ferruginous.

\section{Vor. II.}

* But not with ferruginous as in S. bubo of Europe, 
Short-eared Owl, Strix brachyotos, Wils. Am. Orn. iv. p. 64. pl. 33. fig.3. male.

Inhabits the north of both continents ; in winter as fal south as Pennsylvania; breeds to the north.

$$
\text { t† Head not tufted (Ulula, Cuv.) }
$$

30. Strix nerurosa, L. Pale brown with transverse whitish spots ; beneath whitish, neck and breast with transverse bars, belly and vent with longitudinal streaks, of brown; tail reaching beyond the wings; bill yellow.

Barred Owl, Strix nebulosa, Wils. Am: Orn. iv. p. 61. pl. s3. fig. 2.

Inhabits the north of both continents, extending farther to the south in this: common in Pennsylvania and New Jersey, especially during winter.

31. Strix Acadica, Gm. (5.) Dark brown, spotted with white; beneath whitish spotted with reddish-brown; tail short, reaching about to the tip of the wings: very small.

Little Owl, Strix passerina, Wils. Am. Orn. iv. p. 61. pl. 34. fig. 2 .

Inhabits the north of both continents, but more common in America, in the northern and middle states : resident in Pennsylvania and New-Jersey; more frequent towards the sea.

\section{\$. Bill straight at base.}

SUBGENUS III. STRIX.

Strix, Savigny. Cuv.

Auricular conch as large as in the preceding, with a still larger operculum ; disk much dilated; bill elongated, curved only at tip; tarsus thickly feathered; toes covered by scattered bristles; head not tufted. Nocturnal.

32. Strix flammea, L. Yellowish-tawny, with small spots of white; beneath whitish with blackish points; wings reaching two inches beyond the tail ; bill whitish.

White or Barn Owl, Strix flammen, Wils. Am. Onn. ri. p. 5\%. pl. 50.fig.s. 
Inhabits the north of both continents, but far less frequent in America; seldom observed in Pennsylvania and New Jersey, except in remarkably cold winters. (6.)

\section{ORDER II. PASSERES.}

Passeres, Pica, Accipitres, L. Gm. Passeres, Pica, Columba, Lath.

Scansores, Ambulatores, Rasores, Ill.

Passereaux, Grimpeurs, Gallinacés, Cuv. Sylvicolce, Vieill.

Omnivores, Insectivores, Granivores, Zygodactyli, Anisodactyli, Alcyones, Chelidones, Columba, Temm.

Passeri, Rampicanti, Galline, Ranz. Passeres, Scansores,

Passerigalli, Latr.

BiLr generally short or of middling length, subconic. Feet short or moderate; tibia fleshy, wholly feathered (Alcedo, Merops, Grallaria excepted); tarsi rounded ; toes four, very rarely three, entirely cleft, (Caprimulgus, Musophaga, Penelope excepted) disposed $2-2,3-1,2-1$; hind toe articulated with the tarsus on a level with the rest, bearing on the ground its whole length; nails usually slender, compressed, somewhat retractile, incurved, acute. NECK short or moderate : body slender, compressed. TAIL mostly of twelve feathers, rarely of eight, ten, or fourteen.

Female generally smaller.

Feed on insects, seeds, fruits and berries, some large species also on eggs, small birds and fishes. Monogamous: both sexes construct the nest, sit on the eggs, and rear the young; the male feeds his mate while sitting: nests of some species constructed with great art: eggs generally about five, but vary from two to more than twelve. Young feed from the mouth of the parent, only leave the nest when able to fly, and are afterwards fed until able to provide for themselves. Many species possess great powers of voice, and excel all other birds in singing. 
TRIBE I. SCANSORES.

Zygodactyli, Vieill. Order Scansores, Ill. Cuv. Ranz. Latr. Order Zygodactyli, Temm.

Toes two before and two behind; inner hind toe rarely wanting.

\section{FAMILY III. PSITTACINI.}

Psittacini, Ill. Vieill. Latr. Antilambani, Ranz.

Order Prehensores, Blainville.

Bicl short, large, extremely hard and robust, very high, somewhat compressed, convex above and below, with a cere at base; both mandibles moveable; upper curved from the base, hooked at tip, margins angular; lower shorter, recurved at tip, truncate : nostrils basal, orbicular, perforated in the cere, open : tongue fleshy, thick, entire, rounded at tip, sometimes penicillated. FEet short, robust; tarsus naked, reticulated, shorter than the outer toe; fore toes united at base, opposable to the hind ones; outer hind toe not versatile; sole broad and flat; nails incurved, rather large and acute. Wings large; three outer primaries subequal. TAIr. of twelve feathers, more or less rounded.

Female generally similar to the male. Young differing greatly from the adult, and changing repeatedly before attaining their full plumage. Colours brilliant.

Dwell in forests; noisy, more particularly at the rising and setting of the sun. Climb by means of the bill and feet; and in some species with the assistance of the tail. From the conformation of the feet they supply the place of hands. Feed on fruits and seeds, breaking the hardest pericarps with their powerful bill. Build in cavities of trees; some in the bifurcation of large limbs; lay from two to four eggs twice a year. Macerate the food for their young. Easily tamed; omnivorous in captivity; some learn with facility to articulate many words. Analogous to the mammiferous family Simiæ: oughtperhaps to be placed at the head of the feathered 
tribe, as the most perfect and intelligent; seem, however, to form the link between Passeres and Accipitres, as the Columbini between Passeres and Gallinæ: certainly as ordinately distinct as that group of birds.

Abound in the warm climates of both continents. No species found in Europe; one in the United States.

\section{PSITTACUS.}

Psittacus, L. Briss. Gm. Lath. Cuv. Temm. Psittacus, Pezoporus, Ill. Psittacus, Macrocercus, Plyctolophus, (since Cacatua) Vieill. Solenoglossus, Psittacus, Pezoporus, Ranz.

\section{SUBGENUS PSITTACUS.}

Psittacus, Vieill.

Upper mandible furnished internally with a transverse process near the tip.

33. Psittacus carolinensis, L. Green; head and neck yellow; forehead and cheeks orange; tail elongated, cuneiform.

Young destitute of the yellow colour.

Carolina Parrot, Psittacus carolinensis, Wils. Am. Orn. iii. p. 89. pl. 26. fig. 1.

Inhabits the southern and western states: gregarious: common.

\section{FAMILY IV. AMPHIBOLI.}

Amphiboli, Serrati, Ill. Barbati, Imberbi, Vieill. Pogonofori, Agenii, Ranz. Pogonorynchi, Cuculides, Latr.

BiLL of middling length and strength, slightly curved at tip : tongue short, simple. FEET short or moderate; tarsi annulated; fore toes entirely cleft; outer hind toe versatile. TAIL of from eight to twelve feathers.

\section{COCCYZUS.}

Cuculus, L. Briss. Gm. Lath. Ill. Cuv. Couas, Le Vaillant. Coccyzus, Vieill. Temm. Ranz. Cuv. (as a subg.)

BiLL glabrons, rather robust, long, compressed, carinated 
above and beneath ; margins entire; both mandibles curveas from the base; upper a little longer : nostrils basal, lateral, oval, half closed by a naked membrane : tongue short, narrow, acute. FeEt slender; tarsus naked, much longer than the longest toe; nails short, but little incurved. WINGS short, rounded; spurious feather short; third, fourth and fifth primaries longest. TaIL moderate or elongated, rounded or cuneiform, of ten feathers.

Inhabit the warmest parts of both continents: none in Europe: two in North America during summer. Replace here Cuculus of the old continent, from which they differ, especially in habits. Build a nest in hollow trees, and breed up their young; reside in dense forests; seldom alight on the ground; feed on insects and berries.

34. Coccrzus americanus, Nob. Greenish-drab, beneath white; inner vanes of the primaries reddish-cinnamon; lower mandible and eyelids yellow.

Yellow-billed Cuckoo, Cuculus carolinensis, Wils.Am. Orn. iv. p. 13. pl. 28. fig. 1 .

Cuculus americanus, L. Coccyzus pyropterus, Vieill.

Inhabits common in the United States where it breeds: winters in tropical America.

35. Coccyzus erythrophthalmus, Nob. Greenish-drab, beneath white ; no cinnamon colour on the wings; bill entirely black; eyelids red, naked.

Black-billed Cuckoo, Cuculus erythrophthalmus, Wils. Am. Orn. iv. p. 16. pl. 23. fig. 2.

Inhabits common in the United States where it breeds: winters in tropical America. (7.)

\section{FAMILY V. SAGITTILINGUES.}

Sagittilingues, Ill. Macroglossi, Vieill. Beloglossi, Ranz. Proglossi, Latr. Second family of the Zygodactyli, Temm.

BrLustraight, seldom a little curved at tip; conic-elongated, 
acute; margins entire : tongue extremely long, extensible, lumbriciform. FeET short, robust; tarsus annulated; fore toes united at base; hind toes divided; outer not versatile; inner rarely wanting. TAIL of from ten to twelve feathers.

Reside chiefly in forests and orchards : climb upwards with great facility : feed on insects, especially such as lie concealed under the bark of trees; obtain these by means of their tongue, which is acute and hard at tip, and covered by a glutinous secretion. Build in the cavities of trees; breed once a year; eggs $3-8$; young taught to climb at first : not easily domesticated.

\section{PICUS.}

Picus, L. Briss. Gm. Lath. Ill. Cuv. Vieill. Temm. Ranz. Picus, Picoides, Lacépìde.

BrLu robust, straight, pyramidal-polyedral, cuneate at tip; mandibles subequal, upper rather longer: nostrils basal, oval, open, partly covered by setaceous incumbent feathers: tongue mucronate at tip, with retrorse bristles. INNER HIND TOE shortest, rarely rudimentary or wanting; nails arcuated, acute. Wings moderate; spurious feather short; third and fourth primaries longest. TAIL cuneiform, of twelve feathers, very rigid and acute; outer feather very short, sometimes obsolete or totally wanting.

Female resembling the male, though easily distinguished. Young sometimes very different.

Live in woods; solitary, timid, and laborious: smaller American species far less shy than those of Europe. Climb with admirable agility on the trunks of trees, their sharp nails enabling them to adhere to the bark, and the rigid tail serving for a support : seldom walk on the ground or stand on the branches of trees. Excavate dead trees, but seldom living ones. Hearing acute, directing them to the position of their prey beneath the bark, consisting principally of larvæ which they extract by cutting through the bark with repeated blows of the bill producing a stridulous sound, startling in the silence of 
forests. Hunger sometimes compels them to eat fruits, which a few species prefer. The more powerful prepare for their nests by perforating the wood, but the weaker are content with ready made holes.

Inhabit almost every country of the globe.

* Feet four toed.

$\dagger$ Bill somewhat curved.

36. Prcus aurates, L. Brownish, barred with black; beneath yellowish-white, spotted with black : a black crescent on the breast; a red occipital band; wings and tail beneath, and shafts of all the larger feathers golden yellow.

Male, mustaches black. Female, no mustaches.

Young dirty gray, without the red band a d black crescent. Gold-winged Woodpecker, Picus auratus, Wils. Am. Orn. i. p. 45. pl. 3. fig. 1. male.

Inhabits common in all North America, where it breeds and is resident, though partially migrating; most numerous in spring and autumn. Alights on branches, but climbs well.

t† Bill straight.

a. Crested.

37. Prcus principalrs, L. Black; crest red and black; secondaries, rump, and a stripe each side, white; bill white.

Female and young, crest totally black.

Ivory-billed Woodpecker, Picus principalis, Wils. Am. Orn. iv. p. 20. pl. 29. fig. 1. male.

Inhabits the southern states and Mexico: common, resident.

38. Picus pileatus, L. Brownish-hlack; crest red; chin, a stripe each side of the neck, base of the quill feathers, and under-wing coverts, white; bill black.

Male, mustaches red. Female and young, mustchoes dusky. 
Pileated Woodpecker, Picus pileatus, Wils. Am. Orn. iv. p. 27. pl. 23. fig. 2. male.

Inhabits North America from Canada to Mexico: more common in the north.

\section{b. Not crested.}

39. Picus entrhocephalus, L. Head, neck, and throat crimson; back, wings and tail, black; secondaries, rump and all beneath, white.

Young varied with blackish and dull gray; no red; beneath whitish ; rump, secondaries, and margins of the primaries white.

$\boldsymbol{R}$ d-headed Woodpecker, Picus erythrocephalus, Wils. Am. Orn. i. p. 142. pl 9. fig. 1. adult

Inhabits all North America; much more numerous during summer in the middle states.

40. Picus carolinus, L. Striped with black and white; head and, neck above red; cheeks beneath parts pale buffash; belly tinged with red.

Female and young, fore part of the head destitute of red; but little red on the belly.

Red-bellied Woodpecker, Picus carolinus, Wils. Am. Orn. i. p. 113. pl. 7. fig. 2. male.

Inhabits throughout North America.

41. Picus varius, L. Varied with black and white; back spotted with yellow; crown and throat red; breast and belly yellow.

Female, throat and occiput whitish.

Young varied with dull gray, black and white; a broad white band across the wings; belly yellowish.

Yellow-bellied Wondpecker, Picus varius, Wils. Am. Orn. i.p. 147. pl. 9. fig. 2. male; and nob. Am. Orn. i. p. 75. pl. 8. fig. 1. 2. young in different states.

Inhabits all North America in plenty, from near the pole to the equator: migratory in unfavourable seasons.

VoI. II. 
42. Picus viluosus, L. Varied with black and white; beneath white; back with long, slender, loose feathers; outer tail feathers totally white.

Male, a red occipital band. Female, occipital band black.

Hairy Woodpecker, Picus villosus, Wils. Am. Orn.i.p. 150. pl. 9. fig. 3. male.

Inhabits all North America from Georgia to near the Arctic circle : common.

43. Picus pubescens, L. Varied with black and white; beneath white; back with long, slender, loose feathers; outer tail feathers white, with four black spots.

Male, a red occipital band. Female, occipital band black.

Downy Woodpecker, Picus pubescens, Wils Am. Orn. i. p. 153. pl. 9. fig. 4. male.

Inhabits throughout North America; common. The smallest of the North American species.

44. Picus querulus, Wils. Varied with black and white; back barred with white; beneath white; outer tail feathers white spotted with black.

Male, a short red line each side of the head.

Female, destitute of the red line.

Red-cockaded Woodpecker, Picus querulus, Wils. Am. Orn. ii. p. 103. pl. 15. fig. 1. male.

Inhabits to the southward of Virginia : common.

45. Picus torquatus, Wils. Black glossed with green; front, chin and cheeks, dark red; collar round the neck, and breast silvery white; belly glossy vermilion.

Lewis' Woodpecker, Picus torquatus, Wils. Am. Orn. iii. p. 31. pl. 20. fig. 3.

Inhabits west of the Mississippi : common.

$$
\text { * Three-toed 2-1. }
$$

46. Picus trinactrues, L. Varied with black and white; neck before and breast, pure white; tarsus feathered.

Male, top of the head golden-yellow.

Female, top of the head silvery white, with fine black lines. 
Picus hirsutus Vieill. Ois. pl. 124. adult male.

Inhabits high northern latitudes of both continents; rarely seen in the United States. Unlike other northern birds, not extending so far south in America as in Europe. (8)

TRIBE II. AMIBULATORES.

Anisodactyli, Vieill. Order Ambulatores, Ill. Order Passeres, Cuv. Ranz. Orders Onnivures, Insectiveres, Granivores, Anisodactyli, Alcy'nes, Chelidones, Columba, Temm. Orders Passeres, Passericalli, Latr.

Toes $3-1$, none of the anterior versatile: very rarely $2-1$, the inner wanting.

\section{FAMILY VI. ANGULIROSTRES.}

Angulirostres, Ill. Syndactyli, Cuv. Latr. (not Ill. nor Runz.) Pelmatodes, Vieill. Ranz. Order Alcyones, Temm.

BicL elongated, acute, angulated: tongue short, simple. FEET very short; tibiæ partly naked; tarsi reticulated; middle toe united to the outer, at least to the second joint, and to the inner to the first; the latter rarely wanting.

Female and young hardly differing from the adult male.

Reside near water. Fly remarkably well; rest on trees or on stones, hardly ever on the ground; feet too short for walking or leaping. Feed on insects which they take on the wing, or on fishes, which they seize near the surface of the water. Breed in holes on the banks of streams: eggs numerous. Voice harsh. Not easily tamed.

\section{ALCEDO.}

Alcedo, L. Gm. Lath. Ill. Cuv. Vieill. Ranz.

Ispida, Briss. Alcedo, Ceix, Lacep. Alcedo, Dacelo, Leach. Temm.

BiLL elongated, cleft to the eyes, robust, straight, tetragonal, compressed, acute ; margins finely crenate-fimbriate; upper mandible but little longer than the lower, carinate, 
rarely somewhat curved at tip; lower nearly straight, little recurved at tip: nostrils basal, approximated, oblong, oblique, more than half closed by a naked membrane : tongue very short, fleshy, depressed, narrowed and acute at tip. FEET robust; tarsus one half shorter than the middle toe, which is nearly equal to the outer ; inner considerably shorter than the middle one, rarely wanting; hind toe wide at base, nearly equal to the inner : nails incurved, compressed, channelled beneath, that of the middle toe largest and dilated interiorly. Wings rather short; first and second primaries a little shorter than the third, which is longest.

Body thick, compact; head large, elongated: plumage close, glossy. Moult annually.

Solitary. Abstemious : feed on insects, crustacea, mollusca, and principally small fishes, which they watch for from a perch, catch with admirable dexterity and swallow entire, afterwards casting up the scales and other indigestible parts in the form of pellets. Fly with celerity short distances, skimming the surface of the water or land.

Spread all over the globe, abounding most in warm climates; one species in Europe, and one in the United States.

47. Alcedo alcron, L. Crested; bluish-slate; breast with a ferruginous band; spot before and behind the eyes, a large collar round the neck, and the vent, white.

Belted King-fisher, Alcedo Alcyon, Wils. Am. Orn. iii. p. 59. pl. 23. fig. 1 .

Inhabits common from Hudson's Bay to the equator, and probably still farther south: migrating in cold and temperate regions.

FAMILY VII. GREGARII.

Gregarii, Coraces, 77 . Conirostres, Cuv. Latr. Textores, Leimonites, Coraces, Carunculati, Paradisei, Vieill. Ifanti, Metrioramfi, Plercoramfi, Ranz. Order Omnivores, Temm.

BıL moderate, hard, robust, straight, acuminate, acute, forming a sinus in the frontal feathers or cultrate; edges 
sharp: nostrils basal, partly covered: tongue not elongated nor extensible, bifid or emarginate at tip. FEeT rubust; tarsi annulated, naked, inner toe free; hind toe more or less elongated, thick; nails compressed, acute. WINGs moderate, or but little elongated; primaries acute at tip.

Omnivorous. Gregarious, at least for a part of the year; live in forests, but chiefly meadows and fields; alight equally on trees and on the ground. Build in trees, some also on cliffs and in houses. Flesh generally hard, unpalatable. Voice harsh and unpleasant. Plumage of several eminently distincuished by colour and texture. For the most part easily tamed and taught to articulate words.

GREG ARII

Bill conic-elongated, entire, forming a sinus in the front feathers. Outer and middle toes united at base. Tail of twelve feathers.

\section{STURNUS.}

Sturnus, L. Briss. Gm. Lath. 1ll. Cuv. T'emm.

Sturnus, Sturnella, Vieill. Sturnus, Amblyramphus, Leach.

BiLl conic-subulate, depressed, rather obtuse at tip; margins vertical; upper mandible somewhat rounded above; lower a little shorter, narrow, compressed : hardly ascending, nostrils oval-elongated, half closed by an arched membrane: tongue cartilaginous, depressed, narrowed, acute and bifid at tip. Tarsus subequal to the middle toe; outer hardly longer than the inner; hind toe stoutest : hind nail longest and largest.

Female hardly distinct. Young differing from the adult. Colours more brilliant in spring, though the moult is annual.

Feed chiefly on insects which they seek in fields and meadows, principally on the ground: some species follow the path of oxen and sheep with this view, and often alight on their backs. Build in holes of trees, houses, \&c. and the American species in tufts of grass. 
Found in all parts of the globe : not numerous in species : arranged in several families by different authors.

SUBGENUS STURNELLA.

Sturnella, Vieill. Sturnus, Alauda, Auct. Cassicus, Daud.

Frontal sinus deep, rounded. Hind toe as long as the middle one, much longer and stouter than the lateral. Wings rather short, somewhat rounded; no spurious feather; first and fifth primaries subequal; second, third, and fourth longest : two of the secondaries much elongated.

Peculiar to America. Connecting Sturnus with Icterus by the subgenus Cassicus : somewhat allied to Alauda (family Passerini.)

48. Sturnus ludovicianus, L. Beneath, and line over the eye yellow; a black pectoral crescent; four lateral tail feathers white.

Meadow Lark, Alauda magna, Wils. Am. Orn. iii.p. 20. pl. 19. fig. 2.

Inhabits meadows and fields throughout the Union: common.

\section{ICTERUS.}

Icterus, Briss. Daud. Temm. Panz. Oriolus, Tanagra. L. Gm. Lath. Xanthornus, Pallas. Xanthornus, Icterus, Lacep. Oriolus, Cassicus, Ill. Cassicus, Cuv. Pendulinus, Yphantes, Agelaius, Cassicus, Passerina, Vieill.

BiLl conic-subulate, compressed, rarely a little curved, rounded above, very acute; margins irflexed, those of the lower mandible angular near the base : nostrils oval, covered by a membrane: tongue cartilaginous, acute and bifid at tip. Tarsus rather longer than the middle toe; inner toe but little shorter than the outer, and nearly equal to the hind one ; middle toe longest; hind nail twice as large as the others. Wings sub-acuminate; first primary but little shorter than the third and fourth, which are longest. 
Female differing widely from the male, and often much smaller. Young very like the female. Generally moult once a year, but the colours more brilliant in spring; in winter the plumage of the male is somewhat like that of the female.

Gregarious. Omnivorous. Build in trees. Walk rather quick, with the body almost erect. Flight vigorous. Flesh not esteemed.

Numerous in species, and exclusively American: some short, thick-billed species approaching the genus Fringilla, (family Passerini) others with slender bills are allied to Dacnis, subgenus of Sylvia, (family Canori) whilst others again are related to Quiscalus, to Sturnus, \&c.

\section{SUBGENUS II. ICTERUS.}

Xanthornus, Cuv. Genera Pendulinus, Yphantes, Vieill. Bill comparatively slender, slightly bent towards the tip; frontal sinus acute, not deep.

Female about equal in size to the male.

Not constantly gregarious: frequent the woods. Feed chiefly on insects and berries. Solitary when breeding. Build pensile nests, admirably constructed. Allied to the subgenus Dacnis.

49. Icterus baltimore, Daud. Tail nearly even.

Male orange; head, neck above, back, wings and tail, black; lateral tail feathers widely orange at tip.

Female and young, the orange pale; the black dull and pale, and mottled with dull orange; tail orange.

Baltimore Oriole, Oriolus baltimore, Wils. Am. Orn. i. p. 23. pl.1. fig.3. male; and vi. p. 88. pl. 53. fig. 4. female.

Inhabits all parts of the United States in summer : rather common: winters in tropical America.

50. Icterus spurius, Nob. Tail cuneiform.

Male, chesnut; head and neck, back, wings and tail, black.

Female and young of one year, olive-green, beneath yellow ; wings and tail dusky. 
Young male over one year, the same, with the throat black.

Orchard Oriole, Oriolus mutatus, Wils. Am. Orn. i.p. 64 . pl. 4. fig. 1. female, fig. 2. male two years old, fig. 3. male three years old. fig. 4. adult male. Oriolus spurius, $L$.

Inhabits all parts of the union in summer : rather common.

SUBGENUS III XANTHORNUS.

Xanthornus, Cuv. Genus Agelaius, Vieill.

Bill robust, straight; sinus angle acute, not deep.

Female half the size of the male.

Constantly gregarious: avoid woods, living chiefly in meadows. Feed principally on insects and seeds. Build in society; nests not constructed with much art.

51. Icterus pheniceus, Daud. Black; lesser wing-coverts red.

Young and autumnal male, feathers skirted with rufous.

Female and very young, blackish varied with whitish.

Red-winged Starling, Sturnus prodatorius, Wils. Am. Orn. iv.p. 30.pl. 30. fig. 1. male in summer dress fig. 2. female.

Inhabits the whole of North America in very numerous flocks: departing from the northern states in winter.

52. Icterus xanthocephalus, Nob. Black; head, neck and breast yellow-orange; a white spot on the wing.

Female and young dark brown; wings immaculate; throat whitish; a rounded yelluw patch on the breast.

$\boldsymbol{Y}$ fllow-headed Troopial, Icterus icterocephalus $\mathcal{N o b . ~ A m . ~}$ Orn. i.p. 26. pl. 4. fig. 1. male. fig.2. female.

Inhabits the western territory of the United States, Mexico, and South America: common.

\section{SUBGENUS IV. EMBERIZOIDES.}

Passerina, Vieill. Fringilla, Emberiza, Sturnus, Oriolus, Tanagra, \&c. auct.

Bill short, thick, conic, not much acuminated, straight; frontal sinus acute, not deep.

Intimately allied to Fringilla; though still more closely related to the preceding subgenus. 
i3. ICterus Pecoris. Temm. Glossy black; head and neck. deep silky drab.

Female sooty-brown, beneath pale.

Young similar, the breast spotted.

Cow Bunting, Emberiza pecoris, Wils. Am. Orn. ii.p. 145 . .pl. 18. fig. 1. male. fig. 2. female. fig. 3. young.

Inhabits in summer, Canada and the northern states, in winter the southern and Mexico: found also in South Amme rica : common: migrating in large flocks. The only species known, that, like the European Cuckoo, deposits its eggs in the nests of other birds: like the European Starling it follows cattle and alights on their backs. Intimately allied to the preceding subgenus, to which it may with propriety be united.

54. Icterus agripennis, Nob. Tail feathers very acute.

Adult male in spring dress, hlack; hind head crean colour; scapulars, rump, and tail coverts, white.

Female, young, and male, in summer, autumn, and winter dress, varied with brownish-black and reddish-olive; beneath. dull yellow.

Rice Bunting, Emberiza oryzivora, Wils. Am. Orn. ii. p. 48. pl. 12. fig. 1. male in spring dress. fig. 2. female.

Inhabits the whole United States during summer : common: wintering in tropical America. Breeds north of the fortieth parallel.

Anomalous: strictly intermediate between Fringilla (Family Passerini) and Icterus, (Family Gregarii) : particularly related to the acute-tailed North American Fringillæ. Toes very long, and tail, formed like that of the Woodpecker, often used in the same manner for the purpose of climbing on the reeds and rice.

CORACES.

Bill cultrate, edges sharp. Outer toe free, or hardly united at base to the middle one.

Vor. II. 


\section{QUISCALUS.}

Gracula, Oriolus, Turdus, Corvus, L. Gm. Lath. Picas Icterus, Briss. Ictcrus, Ill. Temm. Ranz. Quiscalus, Penduïnus, Agelaius, Vieill. Sturnus, Daud. Cassicus (Icterus), Ploceus, Cuv. Chalcophanes! Temm.

BrLl bare, compressed from the base, entire; edges angular, very sharp, hardly inflexed : upper mandible prolonged :o an acute angle on the front, curved from the middle, projecting considerably over the lower, with an osseous carina within : nostrils oval, half closed by a membrane : tongue cartilaginous, flattened, lacerated on the sides, bifid at tip. Tarsus a little longer than the middle toe; lateral toes subequal, the inner free, the outer united at base with the middle one. Wings moderate : first primary equal to the fifth, and but little shorter than the second, third, and fourth, which are longest. 'TAIL of twelve feathers, more or less rounded.

Male glossy black, immaculate; female (one species excepted) brownish, beneath whitish-brown. Young differing from the adult. Moult annually, but by the tips of the feathers wearing off, one species undergoes a change.

Gregarious in large flocks; retire in winter to hot climates. Build socially in trees; lay about five eggs. Flesh unpalatable.

55. Quiscalus major, Vieill. Glossy-black; tail cuneiform, reaching beyond the wings nearly five inches; osseous carina small : length sixteen inches.

Female light brown, beneath and eye-brows whitish: length twelve and a half inches.

Great Crow-Biackbird, Quiscalus major, nob. Am. Orn. i. p. 35. pl. \& fig. ! male. fig. . female.

Inhabits the southern states, principally on the sea coast, Mexico, and the West Indies : common.

56. Quiscalus versicolor, Vieill. Glossy-black : tail cunei- 
form, reaching beyond the wings nearly three inches; osseous carina large: length eleven and a half inches.

Female similar to the male, but less brilliant: length eleven inches.

Purple Gralile, Gracula quiscala, Wils. Am. Orn. iii. 2) 44. pl. 21. fig. 4. male and Common Crow-Blackbird, Quiscalus versicolor, nob. Am. Orn. vol. i. p. 42. pl. 5. fig. 1. female.

Inhabits throughout the United States; wintering in the south : common.

5\%. Quiscalus Ferrugrnets, nob. Glossy-black, more or less skirted with ferruginous; tail nearly even : length nine inches.

Female nearly equal to the male; head, neck and breast, ferruginous-brown; belly and rump ash.

Rusty Grakle, Gracula ferruginea, Wils. Am. Orn. vol. iii. p. 41. pl. 21. fig. 3. male in spring.

Inhabits throughout the United States, winters in the south: extends its migrations as far north even as to the Arctic circle: rather less common than the preceding. (9.)

\section{CORVUS.}

Corvus, L. Gm. Laih. Cuv. Ill. Temm. Ranz.

Corvus, Pica, Garrulus, Briss. Vieill.

BrLL covered at base with setaceous incumbent porrect feathers, straight, convex, cultrate-compressed; upper mandible curved at tip ; lower somewhat shorter, carinated on the sides, iittle ascending at tip: nostrils basal, patulous, covered by the incumbent feathers: tongue short, cartilaginous, acute and bifid at tip. TArsus hardly longer than the middle toe; toes separated almost to the base, middle one longest, inner shorter than the outer, and subequal in length to the hind toe: nails moderate, acute, beneath canaliculate, and sharp edged; hind one generally longer. Wings subelongated, acute; first primary short; third or fourth longest. Tais of twelve sicathers. 
Female hardly distinct in colour from the male. Young somewhat different from the adult before the first year. Moult annually. Very shy, suspicious, avoid snares; sense of smelling acute.

Live in forests and fields, generally in scattered flocks. Several migrate. The larger species occasionally prey on small birds, and are very fond of eggs. Build in high trees, rocks, or fissures of old edifices. Lay only once in the year; eggs 3-8. Easily tamed, susceptible of attachment; capable of articulating words; purloin and conceal small articles not useful to themselves.

Spread all over the globe.

SUBGENUS I. CORVUS.

Corvus, Briss. Vieill.

Bill thick, robust. Head feathers not erectile. Tail moderate, even, or slightly rounded. Colours black, not variegated.

Walk gravely. Flight elevated, long sustained.

58. Corvus corax, L. Black; back glossed with bluishpurple; tail much rounded, reaching two inches beyond the wings; third primary longest: length twenty-six inches.

Raven, Corvus corax, Wils. Am. Orn. ix. p. 113. pl. 75 . fig. 3.

Inhabits almost every part of the globe : rare in Pennsylvania, but numerous in the interior of the United States, and to the north near the lakes.

59. Convus corone, L. Purplish-black, glossy; tail slightly rounded, reaching but little beyond the wings; tail-feathers acute; fourth primary longest; first equal to the ninth: length eighteen and a lalf inches.

Crow, Corvus corone, Wils. Am. Orn. iv. p. 79. pl. 36. fig. 3.

Inhabits both continents, very common : more frequent in the northern and middle states than in the southern. 
60. Corvus ossifragus, Wils. Glossy-black; chin naked; tail slightly rounded, reaching more than one inch beyond the wings; fourth primary longest; first much shorter than the ninth : length sixteen inches.

Fish Crow, Corvus ossifragus, Wils. Am. Orn. v. p. 2\% pl. 37. fig.2.

Inhabits the sea coast, pond and river shores of the southern, western, and middle states, during summer : rather rare.

61. Corvus columbianus, Wils. Light silky drab; wings and tail glossy black; secondaries white at tip ; outer tail feathers white.

Clark's Crow, Corvus columbianus, Wils. Am. Orn. iii. p. 29. pl. 20. fig. 2 .

Inhabits the shores of the Oregan : common.

SUBGENUS II. PICA.

Pica, Briss. Vieill.

Head feathers not erectile. Tail very long, cuneiform. Colours generally black and white, sometimes variegated.

Advance by small leaps. Flight generally low, not promtracted.

62. Corvus prca, L. Glossy-black; belly, primaries on the inner web, and scapulars, white; tail about ten inches long.

Magpie, Corvus pica, Wils. Am. Orn. iv.p. 75. pl.35. fig.2。

Inhabits both continents, but much more limited in its range in America, being confined to the northern and western regions. (10.)

SUBGENUS III. GARRULUS.

Garrulus, Briss. Vieill.

Bill rather short, straight; upper mandible somewhat inflected at tip; lower navicular. Head feathers erectile. Wings not reaching to the tip of the tail. Colours brilliant, more or less of blue. 
Garrulous, noisy, inquisitive. Advance by leaps. Flight generally neither protracted nor elevated.

63. Convus cristatus, L. Crested, blue; beneath whitish with a black collar; wing-coverts transversely lineated with black; tail cuneiform.

Blue Jay, Corvus cristatus, Wils. Am. Orn. i. p. 11.pl.1. fig. 1 .

Inhabits every part of North America, more abundant in the northern and middle states; during winter only in the southern.

64. Corvus floridanus, Bartram. Not crested; bright azure; back brownish; beneath whitish-grey; tail subcuneiform.

Florida Jay, Corvus floridanus, nob. Am. Orn. pl. 13. fig 1. Crarrulus cyaneus and carulescens, Vieill.

Inhabits Florila and the neighbouring states to Kentucky.

65. Corvus canadensis. L. Blackish-plumbeous; hind head black; forehead, collar, beneath, and tip of the tail brownishwhite.

Canada Jay, Corvus canadensis, Wils. Am. Orn. iii. p. 33. pl. 21. fig. 1.

Inhabits the colder parts of North America. Rare in the United States, appearing during winter in the northern section only.

\section{FAMILY VIII. SERICATI.}

Sericati, Coruces, Ill. Dentirostres, Cuv. Baceivori, Myiotheres, Vieill. Euristomi, Ranz. Latirostres, Latr. Orders Insectivores, Omnivores, Temm.

Bicl short, robust, dilated, depressed nearly to the tip; upper mandible curved, almost always notched; gape large. FEeT of middling length, somewhat robust; tarsi annulated, naked; hind toe somewhat broad and flat, nails incurved, well proportioned to the toes. WINGS moderate, not acute. TAIs of twelve feathers. 
Gregarious; very sociable; feed on insects and berries. Build without much art. Voice weak and but little modulated.

Form a singular but well defined link between Coraces and Chelidones.

12. BOMBYCILLA.

Ampelis, L. Gm. Lath. Turdus, Briss. Corvus, Ill.

Bombycivora, (subgen.) Cuv. Temim. Bombyciphora, Meyer. Bomb, cilla, Vieill. Ranz. Nob. obs.

BiLc trigonal at base, somewhat compressed towards the tip, notched: upper mandible with an obtuse ridge, curved and acute at tip; lower hardly shorter, compressed, somewhat swelling out at base, recurved, notched, and rather acute at tip ; nostrils basal, oval, patulous, covered by small incumbent setaceous feathers : tongue cartilaginous, broad at tip, lacerated. Tarsus almost equal to the middle toe, which is united at base to the shorter outer toe; inner free, shorter than the outer, almost equal to the hind toe, but more slender; nails acute, middle one almost equal to the hind nail, but more slender at tip. Wings with spurious feather extremely short; first and second primaries longest.

Female similar to the male, crested; adults with small red oblong appendages, like red sealing wax, at the tip of the secondaries. Plumage of a very fine silky and glossy texture, lying extremely close. Moult annually.

live in numerous flocks. Wandering: perform great journeys; not shy, simple, and easily tamed. Feed chiefly on juicy fruits. Build in trees; lay twice a year; eggs about 5 .

Composed of but two species, one American, and the other European and Asiatic.

66. Bombycilla carolinensis, Briss. Drab; chin, frontlet and line over the eye, black; belly yellow; vent white; wings and tail blackish, the latter tipped with yellow.

Cedar Bird, Ampelis americana, Wils. Am. Orn. i. n. $10 \%$ pl. 7. fig. 1. Bombycilla, cedrorum, Vieill. 
Inhabits all North America; more common in the northern and middle states; in winter also in the southern, Mexico, and even Cayenne.

\section{FAMILY IX. CHELIDONES.}

Hiantes, Ill. Fissirostres, Cuv. Chelidones, Vieill. Ranz. Latirostres, Latr. Order Chelidones, Temm.

BinL very small, much depressed, very wide at base; up. per mandible incurved, compressed at tip : gape very large. Feer very short and slender; tarsi annulated; toes short; nails short, arcuated, more or less slender and acute. Wings greatly elongated, very acute.

Female and young generally differ but little from the adult male. Moult annually.

Feed exclusively on insects, which they swallow flying. Migrate to tropical countries in winter. Flight very rapid and protracted: hardly walk. Vision acute, diurnal or nocturnal. Voice destitute of harmony or modulation.

\section{NOCTURNAL.}

Head very large; eyes and ears very large. Middle toe nail pectinated on the inner side. Plumage loose, soft, and light.

\section{CAPRIMULGUS.}

Caprimulgus, L. Briss. Om. Lath. Cuv. Ill. Temm. Ràz: Caprimulgus, Nyctibius, Vieill.

Bict extremely short, feeble, cleft beyond the eyes; upper mandible almost always surrounded by divergent bristles, somewhat hooked at tip; lower somewhat recurved at tip; margins vertical or turned outwards: nostrils basal, wide, partly closed by a feathered membrane, leaving generally a tubular opening: tongue very small, cartilaginous, more or less acute, narrow, entire. Tansi partly feathered; fore toes connected to the first joint by a small membrane; middle toe generally much longer than the lateral and pos- 
terior, the latter slender, versatile : nails very short, canaliculated beneath. First primary shorter than the second and third, which are longest. TAIL of ten feathers.

Female easily distinguished from the male. Young similar to the adult. Moult once or twice in the year. Plumage dull, generally consisting of a mixture of gray, reddishbrown and blackish, with some white spots.

Solitary; shy; live in forests ; abrupt in their motions; fly rapidly about in the twilight and in the night, when their vision is more acute; conceal themselves in the day, except in cloudy weather; flight silent, owing to the softness of the feathers. Hunt insects, principally nocturnal lepidoptera, with a patulous mouth. In the breeding season rustle their wings like the doves; remarkably constant. Lay one or two large eggs on the ground without any nest, rarely in a hollow tree or cleft rock. Voice unpleasant, monotonous. Sometimes when flying utter a noise, probably produced by the air rushing into their open mouth, and circulating in the body.

Inhabit all parts of the globe, but chiefly America. Analo gous to Strix.

67. Caprinulgus carolinensis, $\mathrm{Gm}$. Bristles shorter than the bill; tail rounded, reaching an inch beyond the wings; three outer tail feathers white on the inner web at tip: length twelve inches.

Female, with the tip of the three outer tail feathers dark ochreous.

Chuck-wills-widow, Caprimulgus carolinensis, Wils. Am. Orn. vi. p. 95. pl.54. fig. ..

Inhabits the southern states during summer : rather common.

68. Caprimulgus vocinerus, Wils. Bristles much longer than the bill; tail much rounded, reaching one half beyond the wings; primaries mottled.

VoL. II. 
Male, three outer tail feathers pure white at tip.

Female, tip of the outer tail feathers ochreous.

Whip-poor-will, Caprimulgus vociferus, Wils. Am. Orn.v. p. 71. pl. 41. fig. 1. male, 2. female, 3. young recently hatched. C. virginianus, Vieill. nec auct.

Inhabits the United States during summer : far less common than the following in the middle and northern states.

69. Caprimulgus virginianus, Briss. Bill without bristles; tail forked, not reaching to the tips of the wings; primaries plain blackish, with a white spot.

Male, triangular spot on the throat, and band on the tails white.

Night-Hawk, Caprimulgus americanus, Wils Am. Orn. v. p. 65. pl. 40. fig. 1. male. 2.female. C. popetue, Vieill.

Inhabits the United States during summer, common in the middle states.

\section{DIURNAL}

Eyes and ears moderate. Plumage close and compact. Middle toe nail not pectinated.

\section{CYPSELUS.}

Hirundo L. Briss. Cim. Lath. Cuv. Hirundo, Cypselus, 1ll. Vieill. Ranz. Apus, Scopoli. C'uv. (subg.) Nicropus, Wolf. Meyer. Brachypus, Meyer. Cypselus, Temm.

BiLc extremely short, triangular, cleft to the eyes; upper mandible slightly notched near the tip, which is rather obtuse; lower somew hat shorter, and a little recurved at tip: nostrils lateral, approximate, large, partly covered by a feathered membrane, leaving a small tubular aperture : tongue short, wide, cartilaginous, bifid at tip. FEET remarkably short; toes divided; hind toe versatile, generally directed forward; middle toe a little longer than the Jateral subequal ones; hind toe shortest : nails very retractile, beneath canaliculated; the middle one largest; hind nail smallest: 
Wings extremely long; first primary a little shorter than the second, which is longest TAIL of ten feathers.

Female and young hardly differing from the adult male. Moult annually.

Build in clefts of high rocks and buildings; nests constructed of small twigs, agglutinated together by a viscous substance secreted in the mouth. Flight horizontal and very rapid; rise from the ground with difficulty on account of their very short feet: cling firmly by their claws.

Spread all over the globe.

70. Cypselus pelasgius, Temm. Deep sooty-brown ; chin and line over the eye dull whitish; wings extending one and a half inches beyond the tail; tail even, feathers mucronate.

Chimney Swallow, Hirundo pelasgia, Wils. Am. Orn. v. p. 48. $n l$. 39. fig. 1 .

Inhabits chimneys in all the United States during summer : common : does not extend very far north.

\section{HIRUNDO.}

Hirundo, L. Briss. Gm. Lath. Ill. Cuv. Vieill. Temm. Ranz.

Bill triangular, cleft nearly to the eyes, with a few scattered bristles at the base; upper mandible notched; lower shorter, a little narrower, acute, and nearly straight to the tip: nostrils basal, oblong, posteriorly closed by a membrane, and covered by the frontlet feathers: tongue short, cartilaginous, bifid at tip. TARsus short, slender; middle toe longer than the subequal lateral ones, united with the outer to the first articulation; inner toe free, generally longer than the hind toe, which is not versatile : middle toe nail largest. First primary longest. Tail of twelve feathers, almost always forked.

Female and young often resemble the adult male. Moult annually. 
Social: assemble in large flocks to migrate; live generally in families, constructing their nests together, and often assist each other in the work. Some build in hollow trees, chimneys, and even on the ground; nest artfully constructed, composed of materials that harden by drying, and lined within with feathers and other soft substances : rear usually several broods in a year; both sexes nurse the young. Frequent watery places in pursuit of winged insects, which they take with agility. Skim over the water, drink and wash themselves without alighting. Ascend to the elevated regions of the atmosphere in fair weather ; before rain fly moderately high, and after skim the earth.

Inhabit every part of the globe.

71. Hrrundo purpurea, L. Bluish-purple, glossy; wings and forked tail blackish.

Female and young bluish-brown; belly whitish.

Purple Martin, Hirundo purpurea, Wils. Am. Orn. v. p. 58 . pl. 3?. fig. 1. male. 2. female.

Inbabits the whole continent of America: common during summer throughout the United States.

72. Hirundo rufa, Gm. Above and band on the breast steelblue; front and beneath rufous; tail forked; a white spot on the lateral feathers, outer ones much narrowed and elongated.

Barn Swallow, Hirundo americana, Wils. Am. Orn. v. p. 34. pl. 33. fig. 1. male. 2. female.

Inhabits the United States during summer: common.

73. Hirundo fulva, Vieill. Blue-black, beneath brownishwhite; throat, front and rump ferruginous; tail even.

Fulvous or Cliff Swallow, Hirundo fulva, Nub. Am. Orn. $i$. p. 63. pl. \% fig. 1 .

Inhabits during summer the western parts of the United States, advancing every year more to the eastward: very 
numerous near the Rocky Mountains, and extending far to the north.

74. Hrrundo вicoror, Vieill. Dark greenish-blue, beneath white; tail forked; tarsi naked.

Green-blue, or White-bellied Swallow, Hirundo viridis, Wils. Am. Orn. v. p. 44. pl. $38 . \mathrm{fg}$.3.

Inhabits the United States during summer: less common than the Hirundo rufa.

75. Hirundo riparia, L. Above, and band on the breast, cinereous-brown; beneath white; tail forked; tarsi naked, with a few tufts of downy feathers behind.

Bank Swallow, or Sand Martin, Hirundo riparia. Wils. Am. Orn. v.p. 46. pl. 38. fig. 4 .

Inhabits both continents on high sandy banks, in large communities: during summer only in the United States: common.

\section{FAMILY X. CANORL.}

Dentirostres, Cuv. Latr. Myiotheres, Colluriones, Cannri, Canori, Ill. Ancrpontes, Vicill. Piezoramfi, Lafioramfi, Metrioramfi, Collurioni, Ranz. Order Insectivores, T'emm. Oscines, Brehm.

BiLu short, or moderate; upper mandible almost always notched and curved near the tip. TArsi annulated, naked; middle toe united at base to the outer. Wings moderate. TAIL of twelve feathers.

Insectivorous: some feed also on berries. Build their nests in woods and thickets; breed several times a year; eggs rather numerous. Generally excel in song. Flesh palatable.

\section{MUSCICAPA.}

Muscicapa, Lanius, L. Gm. Lath. Muscicapa, Briss. 11 l. Muscicapa, Tyrannus, Muscivora, Lacep. Cuv. Muscipeta, Cuv. Muscicapa, Muscipeta. Temm Runz. Muscicapa, Tyrannus, Allecturus? Platyrynchos, Vieill. 
BiLL moderate, robust, subtrigonal, depressed, with elongated bristles at base; upper mandible inflected at tip, notched; lower shorter, somewhat flattened beneath, straight, or a little recurved at tip: nostrils basal, lateral, rounded, patulous, partly covered by the bristles: tongue depressed, ciliated at tip. FEex rather short, slender; tarsus equal, or rather longer than the middle toe; inner toe free, or united only at base : nails acute, moderate; hind nail more incurved than the others, larger than that of the middle toe. WINGS rather long, subacute, the spurious feather short or wanting; second and third, or third and fourth primaries longest. TaIL rather long.

Younc differ from the adult only during the first year. Some moult once, others twice a year; after the second moult the male assumes the humble dress of the female. Females of those that moult once a year, similar to their males.

Taciturn; solitury; untameable. Perch on the highese branches of trees, whence they watch for insects; pursuing chiefly diptera, and taking them on the wing with great agility; seldom descend to the ground. Build in woods. Widely distributed over the globe: abounding most where insects are most numerous, and, by preventing their excessive increase, may be considered as benefactors of man. Migratory in temperate and cold regions.

\section{* Larger species. (Tyranni of authors.)}

Bold; attacking and driving victoriously from their nests the most powerful birds of prey.

76. Muscicapa tyrannus, Briss. Blackish, beneath whitish; tail even, black, tipped with white.

Adult, a fulvous spot on the crown. Young without the spot.

Tyrant Flycatcher, or King Bird, Muscicapa tyrannus, Wils. Am. Orn. ii. p. 67. pl. 13. fig. 1.

Inhabits during summer throughout the United States: common. 
7\%. Muscrcapa Crinita, L. Greenish; throat ash ; belly yellow ; wing and tail feathers ferruginous on the inner webs.

Great-crested F/ycatcher, Muscicapa crinita, Wils. Am. Orn. ii. p. 75. pl. 13. fig.2.

Inhabits throughout the United States during summer: rather common.

73. Muscicapa verticalis, Nob. Head and throat ash; a small o ange spot on the crown ; belly yellow ; tail blackish, exterior feather white on the outer web.

Arkunsaw Flycatcher Muscicapa verticalis, Nob. Am. Orn. i.p. 18. pl. 2. fig.2. Tyrannus verticalis, Say.

Inhabits the Arkansaw region near the Rocky Mountains, during summer.

79. Muscicapa savana, Nob. Cinereous; head black; a fulvous spot on the crown; beneath white; tail ten inches long, extremely forked, black.

Fork-tailed Flycatcher, Muscicapa savana, Nob. Am. Orn. i. p. 1. pl. 1. fig. 1 .

Muscicapa tyrannus, L. Tyrannus savana, Vieill.

Inhabits South America : an accidental visiter in the United States.

80. Muscicapa forficata, $\mathbf{G m}$. Light cinereous; beneath white; axillary feathers scarlet; tail greatly elongated, extremely forked, black; outer feathers chiefly rosaceous.

Swallow-tailed Flycatcher, Muscicapa forficata, Nob. Am. Orn. i.p. 15. pl. 2. fig. 1.

Inbabits the trans-Mississippi territories, south-western states, and Mexico.

** Smaller species (Muscicapa, Muscivora, and Muscipeta of authors.)

81. Muscicapa saya, Nob. Dull cinnamon-brown; belly rufescent; tail nearly even; first primary longer than the sixth.

Say's Flycatcher, Muscicapa saya, Nob. Am. Orn. i. p. 20. pl. 2. fig. 3. 
Inhabits near the Rocky Mountains.

32. Nuscicapa fusca, Gm. Dark olive-brown, head blackish ; beneath pale ochreous; bill entirely black; tail emarginate, exterior feather whitish on the outer web.

Pewit Elycatcher, Muscicapa nunciola, Wils. Am. Orn. ii. p. 78. pl. 13. fig. 4 .

Inhabits during summer the northern and middle states, a few wintering in the southern: common.

83. Muscicapa virens, L. Brownish-olive, beneath pale ochreous; bill black, beneath yellow; tail emarginate; second primary longest.

Wood Pewee Flycatcher, Muscicapa rapax, Wils. Am. Orn. ii. p. 81. pl. 13. fig. 5.

Inhabits every part of the United States in summer: common.

84. Muscicapa acadica, Gm. Olive-green, beneath yellowish white ; bill black, flesh colour beneath ; tail slightly rounded; third primary longest.

Small green-crested Flycatcher, Muscicapa querula, Wils. Am. Orn. ii. p. 77. pl. 13. fig. 3.

Inhabits all the United States during summer: rather rare.

85. Muscicapa Ruticilia, L. Black; belly white; sides of the breast, base of the primaries and tail feathers, the two middle ones excepted, orange.

Female, young, and autumnal male, greenish-olive; head cinereous; beneath whitish ; sides of the breast, and base of the tail feathers, yellow.

American Redstart, Muscicapa ruticilla Wils. Am. Orn. $i$. p. 103. pl. 6. fig. 6. adult male, v. p. 119. pl. 45. fig. 2. young.

Inhabits all the United States during summer. Common.

17. ICTERIA.

Muscicapa, Gm. Lath. Turdus, Briss. Ampelis, Sparrman. Tanagra, Desmarest. Pipra Wils. Icteria, Vieill. 
Bicl robust, elongated, convex, curved, compressed, entire, pointed, with divergent bristles at base; mandibles subequal, edges somewhat inflexed: nostrils rounded, obvious, half covered by an arched membrane : tongue cartilaginous, slightly bifid at tip. InNer toe free. First primary a little shorter than the second, third, and fourth, which are longest.

Female similar to the male in colour.

Feed on insects and berries. Conceal themselves in thick bushy places. Alight on the ground, but always near their hiding places, to which they retire as soon as observed. Song greatly varied. Flight irregular.

Peculiar to America; composed of but one species. Intermediate between Muscicapa and Tanagra, but well placed between Turdus and Vireo.

36. ICteria viridis, Nob. Greenish-olive; throat and breast yellow; belly and line encircling the eyes, white.

Yellow-breasted Chat, Pipra polyglotta, Wils, Am. Orn. i. p. 90. pl. 6. fig. ?.

Muscicapa viridis, Gm. Icteria dumicola, Vicill.

Inhabits during summer all parts of the United States: common : winters in tropical America.

18. VIREO.

Muscicapa, Tanagra, L. Grm. Lath. Muscicapa, Briss. I'emm. Vireo, Muscicapa, Sylvia, Vieill.

BiLl rather short, a little compressed, with bristles at base ; upper mandible curved at tip, strongly notched; lowelshorter, recurved at tip : nostrils basal, rounded : tongue cartilaginous, bifid at tip. Tarsus longer than the middle toe. Wings subacute; second or third primary longest.

Female differing but little from the rnale. More or less tinged with green.

Usually insectivorous, but sometimes feeding on berries. Live chiefly on trees, and rarely alight on the ground.

Vor. II. 
Migrate in winter to tropical climates. The greater number sing sweetly.

Peculiar to America. Closely allied to Tamnophilus orz one side, to Muscicapa on another, Sylvia on a third, and Tanagra on a fourth, thus uniting the two families Canori and Passerini. Some of the species correspond to Tamnophilus, in the form of the bill and feet, and differ only in that. of the wings.

8\%. Vireo flavifrons, Vieill. Yellow-olive; throat, breast, frontlet and line round the eye yellow; belly white; wings bifasciate with white, and with the tail blackish.

Yeliow-throated Flycatcher, Muscicapa sylvicola, Wils. Am. Orn. ii.p. 117. pl.\%. fig. 3 .

Inhabits forests during summer : rather common.

88. Vireo solitarius, Vieill. Olive-green; head bluish-gray; line round the eye white; breast pale cinereous; belly white, yellow each side; wings bifasciate with white, and with the tail blackish.

Solitary Flycatcher, AIuscicapa solitaria, Wils. Am. Orn. ii. p. 143. pl. 17. fig. 6 .

Inhabits the southern and middle states during summer: very rare.

89. Vireo noveroracensis, Nob. Yellow-olive; beneath white, sides yellow; line round the eye, and spot near the nostrils, rich yellow; wings bifasciate with pale yellow, and with the tail blackish ; irides white.

White-eyed Flycatcher, Muscicapa cantatrix, Wils. Am. Orn. ii. p. 166. pl. 18. fig. 6 .

Muscicapa noveboracensis, Gm. Vireo musicus, Vieill.

Inhabits the United States during summer, proceeding gradually from the south to the north as the season advances: common.

90. VIreo gilvus, Nob. Pale-green olive; head slightly in- 
clining to ash; line over the eye and all beneath, white; wings dusky, without bands; bill short; irides brown.

Warbling Flycatcher, Muscicapa melodia, Wils. Am. Orn. v. p. 85. pl. 42. fig. 2. Muscicapa (since Sylvia) gilva, Vieill.

Inhabits during summer throughout the union: not very common.

91. Vireo olrvacers, Nob. Yellow-olive; crown ash, with a black lateral line; line over the eye; and all beneath white; wings without bands; bill elongated; irides red.

Red-eyed Flycatcher, Muscicapa olivacea, Wils. Am. Orn. ii. p. 55. pl. 12. fig. 3. Muscicapa olivacea, $L$.

Inhabits every part of the United States during the warm and temperate season: common. Forms the link between Vireo and Sylvia.

\section{LANIUS.}

Lanius, L. Briss. Gm. Lath. Ill. Cuv. Vieill. Temm. Ranz.

Bilc moderate, robust, straight, much compressed, base with rigid, porrect bristles: upper mandible rounded above, hooked at tip, acute, with an acute tooth each side near the tip; lower shorter, acute, notched and toothed near the tip; nostrils basal, lateral, half closed by a vaulted membrane: tongue short, triangular, lacerated at tip. FEET robust; tarsus longer than the middle toe, lateral ones nearly equal; inner free; hind toe wide, at base beneath lattened, more robust than the others, a little shorter than the lateral : nails moderate, compressed, acute; that of the hind toe largest. Wings moderate; spurious feather very short; second and third primary longest. TAIL of twelve feathers:

Female and young of the American species hardly differ from the adult males. Some species moult once, others twice in the year.

Distrustful : courageous: sanguinary. Feed on insects and small birds : take their stand on high limbs whence they watch for prey; hold it while feeding in one foot, standing 
on the other. Attack the most powerful of the feathered tribe, which they drive from their nests. Live in families. Build in trees and bushes; lay 5-7 eggs. Flight short, rapid and irregular: wag the tail. Voice loud, stridulous : imitate the song of other birds.

Found in all parts of the globe, except South America. Resemble the Accipitres, especially in habits; notwithstanding allied to Corvus, but much more closely to Turdus, Myiothera, and other small, feeble birds.

92. Lanius septentrionalis, Gm. (11.) Light slate; beneath white, undulated with brown ; frontlet whitish; wings and tail black; tail feathers, excepting the two middle ones, partly white ; third primary longest ; fourth equal to the second.*

Great American Shrike or Butcher bird, Lanius excubitor, Wils. Am. Orn. i. p. 7. pl. 5. fig. 1. Lanius borealis, Vieill.

Inhabits north of both continents : in winter only in Pennsylvania: rather rare.

93. Lanius ludovicianus, L. Dark slate; beneath white; frontlet black; wings and tail black; tail feathers, four middle ones excepted, partly white; second primary longest; first and fifth equal. $\dagger$

Logger-head Shrike, Lanius carolinensis, Wils. Am. Orn. iii. p. 5\%.pl. . fig.8. Lanius ardosiaceus, Vieill.

Inhabits the southern states.

20. MYIOTHERA.

Turdus, Lanius, L. Gm. Lath. Briss.

Myiothera, Ill. Cuv. Temm. Ranz. Myrmecophaga, Lacep. Myrmothera, Tamnophilus, Vieill.

: In Lanius excubitor of Europe, the second is longest, and the fourth considerably shorter.

$\uparrow$ In Lanius excubitor, and Lanius septentrionalis, the first primary is equal to the sixth. 
Bruc moderate or elongated, much compressed, higher than wide at base, straight or slightly curved; upper mandible a little vaulted, notched and curved at tip; lower a little shorter, straight, notched, ascending at tip, acute: nostrils basal, oval, half closed by a membrane : tongue short, generally somewhat bristled at tip. Tarsus rather slender, very long or moderate; lateral toes subequal, shorter than the middle one, which is united at base with the inner, and to the outer as far as the first articulation; hind toe a little longer and more robust than the inner: nails moderate, incurved, acute; the hind one largest. Wings short, rounded; first primary shortest; the following gradually longer to the fourth or fifth, which is longest. TAIL very short and even, or moderate and much rounded.

Female larger than the male, and, with the young differing considerably in colour from the adult male.

Live generally in families or small troops, different species in company, in dry uninhabited countries, principally dense forests. Feed exclusively on insects, especially ants. Run swiftly on the ground, and leap with agility; seldom alighting, and then on the lowest branches of trees. Flight low and short. Voice harsh and peculiar. Flesh oily and unpalatable. Tropical; chiefly American. Allied to Turdus by Pitta on one side, to Lanius by Tamnophilus on another, and to Troglodytes on a third.

94. Myiothera obsoleta, Nob. Dusky-brownish, undulated with pale; beneath whitish, marked with brown; tail two inches long, rounded, ferruginous-yellow at tip; bill very slender, slightly curved, one inch long; tarsus seven-eighths of an inch.

Rocky Mountain Ant-catcher, Myiothera obsoleta, Nob. Am. Orn. i. p. 6. pl. 1. fig 2. Troglodytes obsoleta, Say.

Inhabits near the Rocky Mountains. Placed on the extreme limits of the genus, near Troglodytes, 


\section{TURDUS。}

Turdus, L. Briss. Gm. Lath. Cuv. Vieill. Temm. Rans.

BicL moderate, much compressed except at base, roundedcultrate, furnished with bristles; upper mandible slightly curved, generally notched; lower shorter, straight, almost rounded : nostrils basal, rounded, half closed by a naked mem. hrane; tongue depressed, cartilaginous, fimbriated, emarginate at tip. Feet rather robust; tarsus longer than the middle toe; inner toe free, hardly longer than the hind one, which is as robust as the middle toe : nails moderate, compressed, incurved, acute; the posterior hardly larger than the middle one. Wings short or moderate; spurious feather short; first and second primaries, second and third, sometimes third, fourth, and fifth, longest; secondaries somewhat rounded at tip ; scapulars hardly longer than the secondaries.

Female and young generally differ little from the male Young more spotted. Moult annually.

Gay. Solitary; several, however, migrate in flocks. Feed on insects and berries. Some eminently distinguished for their admirable song and delicious flesh.

Found in all countries and climates. Allied to the Family Gregarii by Sturnus, and more particularly by Acridotheres; but evidently belonging to this family; closely related to Sylvia, Myiothera, Pitta and Saxicola.

SYIJVANI.

Live and build in woods, thickets and orchards; eggs 4-6. Migrate in flocks. Feed principally on berries, except when bringing up their young.

95. Turdus polyglotros, $L$. Cinereous; beneath and eyebrows whitish; tips of the coverts, primaries at base, and lateral tail feathers, white; tail cuneiform.

Mocking Bird, Turdus polyglotus, Wits. Am. Orna $\ddot{i}_{i_{s}}$ 3. 13. pl. 10. fig. I. 
Inhabits America from New-England to Brazil : rare, and migratory north of the Delaware : common, and resident south.

95. Turdus felivox, Vieill. Deep slate, beneath paler; vent xufous; crown and tail black, the latter rounded.

Cat Bird, Turdus lividus, Wils. Am. Orn. ii. p. 90. pl. 20. fig.3. Muscicapa carolinensis, $\boldsymbol{L}$.

Inhabits during summer throughout North America : very common.

97. Turdus migratorius, L. Dark ash; beneath rufous; head and tail black, two lateral feathers white at the inner tip.

Robin, Turdus migratorius, Wils. Am. Orn。, i. p. 35. pl.2. fig. 2.

Inhabits all North America : extremely common the latter part of autumn, when it arrives from the north in large flocks : a few winter in Pennsylvania.

98. Turdus rugus, L. Reddish-brown; beneath whitish, spotted with black; tail very long, rounded; wings bifasciate with whitish; bill long, entire.

Ferruginous Thrush, Turdus rufus, Wils. Am. Orn. ii。 p. 83. pl. 14. fig. 1 .

Inhabits throughout North America in summer : common: a few resident in the southern states.

99. Turdus mustelinus, $\mathrm{Gm}$. Brown-fulvous, inclining to reddish on the head, and to olive on the rump and tail; beneath white, spotted with blackish; tail short, slightly emarginate; bill moderate.

Wood Thrush, Turdus melodus, Wils. Am. Orn. i. p. 35 . pl. 2. fig. 1.

Inhabits all North America in summer : common : none wintering within the boundaries of the United States.

100. Turdus minor, $\mathrm{Gm}$. Olive-brown, inclining to reddish on the tail; beneath whitish, spotted with dusky on the 
breast and under the wings; tail short, emarginate; bill short.

Hermit Thrush, Turdus solitarius, Wils. Am. Orn. v.p. 95 . pl. 43. fig. 2.

Inhabits all North America in summer : common : resident in the southern states.

101. Turdus wilsonn, Nob. Tawny-brown; beneath white, with brown spots on the throat; tail short, nearly even, the feathers pointed; bill short.

Tawny Thrush, Turdus mustelinus, Wils. Am. Orn. v. p. 98. pl. 43. fig. 3 .

Inhabits all North America, remaining but a few days in Pennsylvania and New Jersey: rather common: breeding in the north; wintering in the south.

\subsection{SYLVIA.}

Motacilla, L. Gm. 1ll. Ficedula, Briss. Sylvia, Scopoli. Lath. Temm. Ranz. Sylvia, Dacnis, (subgenus of Cassicus) Cuv. Sylvia, Mniotilta, Vieill.

Bils slender, straight, subulate, higher than wide at base, furnished with bristles; lower mandible straight: nostrils basal, lateral, oval, half closed by a membrane: tongue cartilaginous : lacerated at tip. FEET slender; tarsus longer than the middle toe; inner toe free; hind toe moderate; nails moderate, compressed, incurved, acute; the posterior shorter than the toe. Wings moderate or short; spurious feather generally short; first and second primaries, second and third, or third and fourth, longest; scapulars considerably shorter than the quill feathers.

Female generally distinguished by a less vivid plumage. Young generally similar to the parents after the first moult. Moult once, some species twice, in the year.

Sprightly. Inhabit forests : migrate from south to north in spring. Feed on insects which they generally take on the 
branches of trees, or pick off from the leaves; seek for worms on the ground; sometimes eat berries. Many sing delightfully.

Spread all over the globe. By some species united to Turdus, Muscicapa and Saxicola, and, by the subgenus Dacnis, connected with Icterus (Family Gregarii), by Regulus to Parus (Family Ægithali), by Troglodytes to Myiothera and even Certhia (Family Tenuirostres), by Anthus to Alauda (Passerini), to which Family it is also connected by some slender-billed Tanagræ. Some species are so closely allied to Vireo, Muscicapa, Turdus, Saxicola, \&c. that they might be placed with almost equal propriety in either. .

\section{SUBGENUS I. SYLVIA.}

Upper mandible slightly curved and notched near the tip. 102. Sylvia Aurocapilza, Nob. Olivaceous; crown brownishorange, margined each side by a black line; beneath white, breast spotted with blackish.

Golden-crowned Thrush, Turdus aurocapillus, Wils. Am. Orn. ii. p. 88. pl. 14. fig. 2. Motacilla aurocapilla, $\boldsymbol{L}$.

Inhabits all the United States during summer, in woods: winters in Mexico and the West Indies: breeds in Pennsylvania : rather common.

103. Sylvia noveboracessis, Lath. Olive-brown; beneath and line over the eye yellowish-white; breast spotted with blackish.

Water Thrush, Turdus aquaticus, Wils. Am. Orn. iii.p. 66 . pl. . 23. fig. 5 .

Inhabits all parts of the United States during summer: common in Louisiana, Tennessee, \&c. ; rather rare in Pennsylvania and New-Jersey, where it appears but a few days in May, on its way north, and on its return in August.

104. Sylvia coronata, Lath. Slate, streaked with black;

VoL. II. 
beneath white, breast spotted with black; crown, sides of the breast, and rump yellow; wings bifasciate with white, and with the tail, black; three lateral tail feathers spotted with white.

Winter plumage brownish-olive; beneath dirty white; yellow of the breast and crown obsolete.

Young, without black or yellow.

Yellow-rump Warbler, Sylvia coronata, Wils. Am. Orn. ii. p. 138. pl.17. fig. 4. summer plumage; and v.p. 121. pl.45. fig.3. winter plumage.

Inhabits all the United States during summer; common: passes through Pennsylvania in the spring whilst in full plumage, and returus in flocks in the autumn in its humble dress : winters in the southern states: breeds in the north and in the mountains.

105. Sylvia palmarum, Lath. Brown-olive; crown rufous; line over the eye, and all beneath, rich yellow; breast streaked; two lateral tail feathers white on the inner tip.

Winter plumage considerably duller; rufous of the crown obsolete; beneath yellowish-white.

Palm Warbler, Sylvia palmarum, Nob. Am. Orn. ii.pl. 10. fig.2. adult male in summer dress, never noticed before.

Inhabits Florida and the West Indies : common : resident : rare and transitory visitant in the middle and northern states, where it is only observed in early spring.

106. Sylvia maculosa, Lath. Crown ash; rump and beneath rich yellow; breast spotted with black; wings bifasciate with white, and with the tail, black; lateral tail feathers white on the middle of their inner vanes.

Black and Yellow Warbler, Sylvia magnolia, Wils. Am. Orn. iii.p. 63. pl. 23. fig.2. adult male.

Inhabits all the United States during summer : rare: re- 
mains only a few days in Pennsylvania, on its way to and from its breeding places.

107. Sylvia maritima, Wils. Yellow-olive, streaked with black; crown and line through the eyes black; cheeks and beneath yellow; breast spotted with black; wings with a broad white band; three lateral tail feathers with a spot of white.

Female dull-olive; beneath whitish spotted with dusky.

Cape May Warbler, Sylvia maritima, Wils. Am. Orn. vi. p. 99. pl. 51. fig. 8. male; and Nob. Am. Orn. i. p. 32. pl. 3. fig. 3. female.

Inhabits Pennsylvania and New Jersey, a few days only in the spring and autumn; very rare.

108. Sylvia pardalina, Nob. Cinereous-brown; crown dappled with black; beneath and line over the eyes yellow; breast spotted with black; tail immaculate.

Canada Flycatcher, Muscicapa canadensis, Wils. Am. Orn. iii. p. 100. pl. 26. fig. 2. male.

Inhabits throughout the United States during summer: rare, especially in the Atlantic States; seen in Pennsylvania but a few days in spring and autumn: breeds to the north.

109. Sylvia mitrata, Lath. Yellow-olive; head and neck black; forehead and cheeks, and body beneath, yellow ; three lateral tail feathers white on one half of their inner webs.

Hooded Flycatcher, Muscicapa cucullata, Wils. Am. Orn. iii. p. 190. pl. 26. fig. 3. male.

Inhabits the United States during summer only : rare north of Maryland; common to the south.

110. Sylvia Pensilis, Lath. Light slate; frontlet, ear-feathers, lores and above the eyes black; throat and breast yellow; belly and line over the eye white; wings and tail black varied with white. 
Yellow-throated Warbler, Sylvia flavicollis, Wils. Am. Orn. ii.p. 54. pl. 12. fig. 6 .

Inhabits the northern parts of the United States during summer : extremely rare as far north as Pennsylvania : winters in the West Indies.

111. Sylvia virens. Lath. Yellowish-green; front, cheeks, sides of the neck, and line over the eye, yellow; beneath white; throat black; wings bifasciate with white, and with the tail, dusky; three lateral tail feathers marked with white.

Black-throated green Warbler, Sylvia virens, Wils. Am. Orn. ii. p. 127. pl. 17. fig. 3 .

Inhabits the United States during summer; in Pennsylvania a few days only in the spring on their way northward, and in the autumn on their return; rather rare.

112. Sylvia blackburnia, Lath. Head striped with black and orange; throat and breast orange, bounded by black spots; wings with a large white spot; three lateral tail feathers white on the inner web.

Blackburnian Warbler, Sylvia Blackburnic, Wils. Am. Orn. iii. p. 64. pl. 28. fig. 3 .

Inhabits the United States during summer; for a few days only in the spring and autumn in Pennsylvania : rare.

113. Sylvia icterocephala, Lath. Crown yellow; beneath white; sides, from the bill, chesnut; wings bifasciate with yellow; three lateral tail feathers marked with white.

Female destitute of chesnut on the sides.

Chesnut-sided Warbler, Sylvia Pennsylvanica, Wils. Am. Orn.i.p. 99.pl. 14. fig. 5 .

Inhabits the United States during summer; a few days only in Pennsylvania in spring and autumn : rare.

114. Sycvia castanea, Wils. Forehead and cheeks black; crown, throat, and sides under the wings, chesnut; wings bifasciate with white; three lateral tail feathers marked with white. 
Bay-breasted Warbler, Sylvia castanea, Wils. Am. Orn. ii. p. $9 \%$ pl. 14. fig. 4 .

Inhabits the United States in summer; in Pennsylvania a few days only in spring and autumn: rare.

115. Sxlvia Striata, Lath. Crown black; cheeks and beneath white; wings bifasciate with white, and with the tail blackish; three lateral tail feathers marked internally with white.

Female and young dull yellow-olive, streaked with black and slate; beneath white; cheeks and sides of the breast tinged with yellow.

Black-poll Warbler, Sylvia striata, Wils. Am. Orn. iv. p. 40. pl. 30. fig. 3. male; and vi.p. 101. pl. 54. fig. 4. female.

Inhabits the United States during summer: rather common.

116. Sylvia varia, Lath. Varied with black and white; crown striped with black; belly pure white.

Male, throat black.

Female and young, throat greyish-white.

Black and white Creeper, Certhia maculata, Wils. Am. Orn. iii. p. «3. pl. 19. fig. 3 .

Inhabits the United States during summer : common.

Forms an immediate link (without Troglodytes) with Certhia, of which it has some of the characters, and all the habits. The genus Mniotilta of Vieillot is formed for its reception.

117. Sruvia prvus, Lath. Olive-green; beneath yellow; vent white; wings bifasciate with white, and with the tail, brown; three lateral tail feathers with a broad white spot near the tip ; lores not black.

Female brown, tinged with olive-green on the back; beneath pale yellowish.

Pine creeping Warbler, Sylvia pinus, Wils. Am. Orn. iii. p. 25. pl. 19. fig. 4 .

Inhabits pine woods of the southern states, common, resident; and New Jersey in summer, rare. 
Resembles Certhia in habits. Misled by Edwards, authors have confounded it with Sylvia solitaria, Wils. from which their description is taken.

118. Sylvia parus, Wils. Black, with a few yellow-olive streaks; head above yellow, dotted with black; line over the eye, sides of the neck, and breast yellow; belly paler, streaked with dusky; wings bifasciate with white, and with the tail black; three lateral tail feathers white on their inner vanes.

Hemlock Warbler, Sylvia parus, Wils. Am. Orn. v. p. 114. pl. 44. fig. 3. male.

Inhabits the great pine swamps of Pennsylvania during summer : rare.

119. Sylvia tigrina, Lath. Yellow-olive; front, cheeks, chin, and sides of the neck, yellow; breast and belly pale yellow, streaked with dusky; wings bifasciate with white, and with the rounded tail black; two lateral tail feathers white on the inner vane from the middle.

Blue mountain Warbler, Sylvia montana, Wils. Am. Orn. u. p. 113. pl. 41. fig. 2. male.

Inhabits the United States during summer : rare.

120. Sylvia rara, Wils. Verditer-green; lores, line over the eye, and all beneath pale cream colour; wings bifasciate with white, and with the emarginated tail, brownishblack; three lateral tail feathers with white on the outer vanes.

Blue-green Warbler, Sylvia rara, Wils. Am. Orn. iii. p. 119. pl. 2\%. fig. 2 .

Inhabits in April on the banks of Cumberland River : very rare.

121. Sylvia discolor, Vieill. Olive; beneath yellow; spotted with black; wings bifasciate with yellow, and, with the tail, brownish-black; three lateral tail feathers broadly spotted with white.

Male, a black crescent under the eye. 
Female, less spotted, and without the crescent.

Prairie Warbler, Sylvia minuta, Wils. Am. Orn. iii. p. 87. pl. 25. fig. 4.

Inhabits the southern parts of the United States, particularly the borders of Kentucky: rare : winters in the West Indies.

122. Syrvia estriva, Lath. Greenish-yellow; forehead and beneath, yellow; breast and sides streaked with dark red; lateral tail feathers interiorly yellow.

Young greenish above; throat white.

Blue-eyed Yellow Warbler, Sylvia citrinella, Wils. Am. Orn. ii.p. 111. pl. 15. fig. 6 .

Inhabits North America as high as the Arctic circle during summer : very common.

123. Sylvia petechia, Lath. Yellow-olive, streaked with dusky; beneath and line over the eye yellow; breast streaked with dull red; crown reddish; wings and tail blackish, edged with olive.

Female, young, and adult male in winter, destitute of the red cap.

Yellow Red-poll Warbler, Sylvia petechia, Wils. Am. Orn. iv. p. 19. pl. 28. fig. 4. adult male in spring.

Inhabits the United States during summer : resident in the most southern states: rare. Specifically distinct from the preceding?

124. Sylvia Americana, Lath. Bluish; inter-scapulars yellow-olive; throat yellow; belly white; wings bifasciate with white; lateral tail feathers marked interiorly with white.

Male, front yellow, with a black crescent; breast tinged with orange.

Female, no crescent nor orange on the breast.

Young brownish-gray; beneath dirty whitish.

Blue Yellow-back Warbler, Sylvia pusilla, Wils. Am. Orn. iv. p. 17. pl. 28. fig. 3.

Inhabits the United States during summer : common. 
125. Sylvia canadensis, Liath. Slate colour; beneath white; cheeks and throat black; a white spot on the wings; three lateral tail feathers with white on the inner web.

Black-throated blue Warbler, Sylvia canadensis, Wils. Am. Orn. ii. p. 115. pl. 15. fig. $\%$

Inhabits North America : transient visitors from the south, where they winter, to the north where they breed: rather rare.

126. Srrvia Agilis, Wils. Yellow-olive; beneath yellow; throat pale ash.

Female, throat dull buff.

Connecticut Warbler, Sylvia agilis, Wils. Am. Orn. $v$. p. 64. pl. 39. fig. 4 .

A spring visitant in Pennsylvania, New-York, and NewEngland : rare.

12\%. Sylvia formosa, Wils. Olive-green; beneath, and line over the eye, yellow; crown deep black, spotted behind with light ash ; lores, and spot curving down the neck, black.

Female destitute of the curved spot.

Kentucky Warbler, Sylvia formosa, Wils. Am. Orn. iii. p. 85. pl. 25. fig. 3 .

Inhabits the south-western part of the union, from Kentucky to New Orleans, during summer : common.

128. Syrvia autumanars, Wils. Olive-green; back streaked with dusky ; beneath, and cheeks dull yellowish; belly white; wings bifasciate with white, and with the tail blackish, each feather edged with white; three lateral tail feathers white near the tip.

Autumnal Warbler, Sylvia autumnalis, Wils. Am. Orn. iii. p. 65. pl. 23. fig. 4.

Passes through Pennsylvania in the spring : rare: more common on its return in October.

129. Sylvia trichas, Lath. Green-olive; beneath yellow; front and wide patch through the eye black, bounded above by bluish-white. 
Female and young dull olive ; beneath dull yellow.

Maryland Yellow-throat, Sylvia marylandica, Wils, Am. Orn. i. p. 88. pl. 6. fig. 1. male; and ii. p. 163. pl. 18. fig. 4. female.

Inhabits the United States during summer : very common : winters in the southern states.

130. Sylvia philadelphia, Wils. Deep greenish-olive; head slate; breast with a crescent of alternate white and black lines; belly yellow.

Mourning Warbler, Sylvia Philadelphia, Wils. Am. Orn. ii.p. 101. pl. 14. fig. 6 .

Found but once in Pennsylvania during summer. An accidental variety of the preceding?

131. Sxuvia sphagnosa, Nob. Deep green-olive; beneath pale ochreous; wings with a triangular spot of yellowish-white; three lateral tail feathers with a whitish spot on the inner vanes.

Pine swamp Warbler, Sylvia pusilla (leucoptera), Wils. Am. Orn. v. p. 100. pl. 43. fig. 4.

Inhabits pine and hemlock swamps in summer; not uncommon.

132. Sylvia azurga, Stephens. Verditer-blue; beneath and line over the eye white; wings bifasciate with white, and, with the tail, black; tail feathers with a white spot.

Carulean Warbler, Sylvia carulea, Wils. Am. Orn. ii. p. 141. pl. 17. fig. 5. male; and Nob. Am. Orn. ii. pl. 11. fig. פ. femile.

Inhabits the northern and middle states in summer : rare in the Atlantic states: common in the western.

133. Sruvia Carulea, Lath. Bluish-gray; beneath bluishwhite; tail longer than the body, rounded, black; outer tail feathers nearly all white, two next tipt with white.

Blue-gray Flycatcher, Muscicapa carulea, Wils. Am. Orn. ii. p. 164. pl. 18. fig. 5.

VOI. II. 
Inhabits the United States in summer : rather common: somewhat rare north of Pennsylvania. Allied to Muscicapa.

134. Sycvia minuta, Nob. Dull yellow-olive; beneath pale yellow; wings and tail dusky-brown; wing-coverts tipt with white; two lateral tail feathers with a white spot on the inner vane.

Small-headed Flycatcher, Muscicapa minuta, Wils. Am. Orn. vi. p. 62. pl. 50. fig. 5. (not his.Sylvia minuta.)

Inhabits the southern and middle states in summer: exceedingly rare in Pennsylvania, less so in New Jersey.

Perhaps not of this genus, but still less a Muscicapa.

135. Sylvia wirsonir, Nob. Olive-green; crown black; front, line over the eye and all beneath, yellow.

Female dull yellow-olive.

Green Black-capt Flycatcher, Muscicapa pusilla, Wils. Am. Orn. iii. p. 103. pl. 26. fig. 4 .

Inhabits the swamps of the southern parts of the United States during summer : rarely in the lower parts of Delaware and New Jersey.

SUBGENUS II. DACNIS.

Dacnis (of Cassicus), Cuv. Pit-pits, Vieill.

Bill thick at base, rounded, pointed, quite straight, entire.

Active, industrious; creeping and hanging by the claws: partaking much of the character of Parus in their habits, voice and action. The stout billed species pass insensibly to the slender billed Icteri and Tanagræ.

136. Sybvia vermivora, Lath. Bright olive; head striped with black and buff; beneath dirty buff; bill long, stout.

Worm-eating Warbler, Sylvia vermivora, Wils. Am. Orn. iii. p. 74. pl. 24. fig. 4.

Inhabits the southern states in summer ; extending its migrations to the middle states; rare in Pennsylvania.

13\%. Syzvia protoxotarius, Lath. Yellow; back and small 
wing-coverts olive; wings, rump, and tail-coverts lead-blue; lateral tail feathers with a spot of white; bill long, stout.

Prothonotary Warbler, Sylvia protonotarius, Wils. Am. Orn. iii. p. 72. pl. 24. fig. 3.

Inhabits the southern states in summer ; common : extremely rare in Pennsylvania.

138. Sylvia solitaria, Wils. Olive-green; forehead, and all beneath, yellow; lores black; wings bifasciate with whitish, and with the tail slate; three lateral tail feathers white on the inner web.

Blue-winged Yellow Warbler, Sylvia solitaria, Wils. Am. Orn. ii. p. 109. pl. 15. fig. 4.

Inhabits the United States in summer : rather rare.

Erroneously described for the Sylvia pinus by authors.

139. Sylvia chrysoptera, Lath. Dark slate; crown and wingcoverts golden-yellow; beneath white; throat and band through the eye black.

Female olive; front and wing-coverts yellow; breast and over the eye, dusky. .

Golden-winged Warbler, Sylvia chrypsoptera, Wils. Am. Orn. ii. p. 113. pl. 15. fig. 5. male; and Nob. Am. Orn. p. 12. pl. 1. fig. 3. female.

Inhabits the United States during summer: appear in Pennsylvania a few days in spring and autumn : rare.

140. Sylvia peregrina, Wils. (12) Yellow olive, bluish on the head; line over the eye pale yellow ; beneath whitish; wings without bands; bill very short.

Tennessee Warbler, Sylvia peregrina, Wils. Am. Orn. iii. p. 83. pl. 25. fig. 2.

Inhabits Tennessee during summer : rare.

141. Sylvia rubricapilia, Wils. Greenish-olive; head and neck light ash; crown dotted with deep chesnut; beneath yellow; belly white; wings without bands. 
Nashville Warbler, Sylvia ruficapilla (rubricapilla), Wils. Am. Orn. ini. p. 120. pl. 27. fig.3.

Inhabits Tennesse, and the neighbouring states, in summer; rare: occasionally visits Pennsylvania in the spring.

142. Sylvia celata, Say. Greenish-olive; crown with a fulvous spot; beneath olive-yellow; vent yellow; wings without bands.

Orange-crowned Warbler, Sylvia celata, Nob. Am. Orn. i. p. $45, \mu ., 5 ., f i \cdot 2$.

Inhabits Missouri in summer : rather common.

23: SAXICOLA.

Motacilla, L. Gm. Cuv. Ill. Ficedula, Briss. Sylvia Lath. Saxicola, Bechst. Temm. Ranz. Wnanthe, Vieill. Vitifiort, Ste ${ }^{\prime}$ hens.

BiLc short, straight, slender, subulate, wider than high at base, cleft nearly to the eyes, furnished with bristles at base; edges inflexed; upper mandible carinated, curved at tip, notched, somewhat obtuse; lower shorter, straight, entire, acute: nostrils basal, lateral, oval, partly closed by a membrane: tongue cartilaginous, emarginate at tip. TARsus rather long and slender; toes moderate; inner free; hind toe a little shorter than the inner, but more robust; hind nail stoutest, shorter than the toe, arcuated. Wings rather long; second and third primaries longest.

FeMale generally resembling the young, and differing considerably from the male. Moult annually, but from the wearing away of their feathers, their spring dress is brighter than that of autumn.

Timid; restless. Reside in open and principally stony countries; live in families or small flocks. Feed chiefly on insects, which they take with great agility of wing. Build on the ground amongst stones, grass, or in holes in fences and trees; eggs 4-5, bluish. Some are always on the ground, 
running in pursuit of flying insects; others alight on small bushes, tops of trees, fences, \&c. seldom on lower branches. Tail continually in motion.

Hitherto considered as peculiar to the old continent. In form of bill and activity in catching insects allied to Muscicapa; closely related to Sylvia, the American species particularly; and comes also very near to that section of Turdus called Saxicolæ.

143. Saxicola stalis, Nob. Blue; beneath ferruginous; belly white.

Female considerably duller.

Young, dusky, spotted with white; beneath dull whitishgray, varied with disky; wirgs and tail bluish.

Blue bird, Sylvia sialis. Wils. Am. Orn. i. p. 56. pl. 3 fig. 3. adult male. Motacilla sialis, $L$. Wnanthe sialis, Vieill.

Inhahits North America during spring, summer, and autumn, as well as the West Indies, Mexico, and South America, where it winters : very common : a few resident in the southern states.

\section{ANTHUS.}

Alauda, L. Gm. Lath. Ill. Motacilla, Cuv.

Anthus, Bechst. Temm. Vieill. Ranz.

BiLL straight, slender, subulate, destitute of bristles ; edges somewhat inflexed in the rniddle; upper mandible carinated at base, then rounded, notched and declining at tip; lower shorter, quite straight: nostrils basal, lateral, oval, half closed by a membrane: tongue cartilaginous, bifid at tip. Feet slender; tarsus longer than the middle toe; inner toe free; hind toe shortest, nail almost always long, straightish. Wings moderate; no spurious feather; first, second and third primaries longest; secondaries emorginate at tip; two of the scapulars nearly equal to the longest primaries. TaIL elongated, emarginated. 
Female and young generally much like the adult male, which assumes somewhat more brilliant colours only during a few days of the breeding season. Moult annually.

Frequent open fields, cultivated grounds, \&c. near the water; the greater part of the species never alight on trees. Feed exclusively on insects. Build on the ground. Move the tail vertically like the Motacillæ. Sing when rising on the wing like the Alaudæ.

Species few, but spread all over the globe. Closely allied to Motacilla in form and habits; to Alauda in colour and structure of the hind nail; exactly intermediate between the two ; thus connecting the two families Canori and Passerini, though remotely distinct from the latter.

144. Anthus spinoletta, Nob. Beneath, and line over the eye, pale rufous; breast spotted with black; tail feathers blackish, the outer half white, the second white at tip; hind nail long, arcuated.

Brown Lark, Alauda rufa, Wils. Am. Orn. v. p. 89.pl. 42. fig 4. Alauda spinoletta, L. Anthus aquaticus, Bechst.

Inhabits the north of both continents ; during winter only in the United States : not very frequent in Pennsylvania.

\section{REGULUS.}

Motacilla, L. Gm. Ill. Cuv. Parus, Briss. Sylvia, Lath. Temm. Ranz. Regulus, Ray, Vieill. Boie. Brehm.

BiLL short, straight, very slender, subulate, compressed from the base, narrowed in the middle, with bristles at base; edges somewhat inflexed; upper mandible finely notched, and a little curved at tip : nostrils basal, oval, half closed by a membrane, covered by two small, porrect, rigid, decompound feathers : tongue cartilaginous, bristly at tip. FEeT slender; tarsus longer than the middle toe; lateral toes subequal; inner free; hind toe stoutest, with a larger and thicker nail. Wings short, rather acute; spurious feather 
very short; third and fourth primaries longest; first and seventh equal. TalL emarginate.

Fenale differs but little from the male; young considerably duller. Moult annually. Feathers long and setaceous; those of the head when separated, discovering a bright spot on the crown.

Delight in cold weather, though chiefly insectivorous. Agile; take their prey on the wing, or on trees, hanging to the extremities of flexible branches in search of small insects in the flowers, and on the leaves. Nest constructed with great art, and affixed to pensile branches; lay once or twice a year; eggs numerous, sometimes twelve..

Inhabit the north of both continents ; very small, in Europe the smallest of all birds. Intermediate between Sylvia and Parus ; closely allied to both.

145. Regulus calendula, Stephens. Olivaceous; beneath whitish; crown vermillion, not margined with black.

Ruby-crowned Wren, Sylvia calendula, Wils. Am. Orn.?. p. 83. pl. 5 fig.3. Regulus rubineus Vieill.

Inhabits North America except in winter; extending its migrations to Greenland; seldom observed in the middle states during summer, as it breeds far to the north; passing north in spring; common on its return in autumn.

146. Regulus cristatus, Vieill. Olivaceous; beneath whitish; crown orange, margined with black; cheeks pale grayish; bill slender from the base.

Female, crown lemon-yellow.

Golden-crested Wren, Sylvia regulus, Wils. Am. Orn. $i$. p. 126. pl. 8. fig. 2. male; and Golden-crowned Gold-crest, Regulus cristatus, Nob. Am. Orn. i.p. 22. pl. 2. fig. 4. female.

Widely extended in both continents; in Pennsylvania observed in April, autumn, and early winter only: breeds in the north: common, 
26. TROGLODYTES.

Motacilla, L. Gm. Cuv. Ill. Sylvia, Lath. Temm. Ranz Troglodytes, Th yothorus, Vieill.

BisL very slender, subulate, somewhat arched and elongated, acute, compressed, entire ; mandibles equal: nostrils basal, oval, half closed by a membrane, obvious : tongue cartilaginous, slender, terminated by two or three small, rigid bristles. FEET slender; tarsus longer than the middle toe; inner toe free; posterior with a larger nail. Wrings short, concave, rounded, with a spurious feather ; third, fourth, and fifth primaries longest.

Female and young hardly difier in plumage from the adult male. Moult annually. Plumage dull, thick, and long. Body rounded.

Active and eccentric in their movements : tail constantly erected. Fond of prying into caves and dark places : hide in thickets and brambles. Feed exclusively on insects, which they seek among dead branches, wood-piles, \&c. Nest constructed with much art; eggs rather nnmerous.

SUBGENUS I. TROGLODYTES.

Troglodytes, Vieill.

Bill slender from the base. Hind toe equal to the inner. Spurious feather moderate.

Almost domestic, building on or near houses. Sing agreeably.

Found in both continents.

147. Trog Lodytes ænon, Vieill. Brown, banded with biack; beneath dull grayish, with obsolete bands; tail long, rounded.

House Wren, Sylvia domestica, Wils. Am. Orn. i. p. 129. pl. 8. fig. 3. Sylvia furva? Lath. (13.)

Inhabits throughout the Union during summer: common. 
148. Troglodytes europeus, Leach. Brown, banded with black; beneath dull rufous-grayish with obsolete bands; tail very short.

Winter Wren, Sylvia troglodytes, Wils. Am. Orn. i. p. 139. pl. 8. fig. 6 Trogiodytes hyemalis, Vieill. (14.)

Inhabits both continents; in America less common, and retiring to the north in summer.

SUBGENUS II. THRYOTHORUS.

Thryothorus, $V$ ieill.

BiLL rather thick at base. Hind toe slender, longer than the inner. Spurious feather elongated, broad.

Keep chiefly in watery places, amongst reeds and aquatic plants, which they grasp, ascending the stem by hops. Voice unpleasant, harsh.

Peculiar to America. Closely allied to Certhia and other Tenuirostres.

149. Troglodytes ludovicianus, Nob. Reddish-brown ; wings and tail barred with black ; beneath light rusty ; a yellowishwhite stripe over the eye.

Great Caroline Wren, Certhia Caroliniana, Wils. Am. Orn. ii.p. 61.pl. 12. fig. 5. Sylvia ludoviciana, sp. 150. Lath.

Inhabits the southern sta es; common; resident : only a summer visitant in the middle states; rare in Pennsylvania, more common in New Jersey.

150. Trog lodytes palustris, Nob. Dark-brown; crown black; neck and back, black, streaked with white; a white stripe over the eye; beneath silvery-whitish; vent tinged with brown.

Marsh Wren, Certhia palustris, Wils. Am. Orn. ii. p. 58. pl. 12. fig. 4. Thryothorus arundineus, Vieill.

Inhabits reeds and other aquatic plants during summer; common; winters south of the United States.

VoL. II. 
FAMILY XI. TENUIROSTRES.

Tenuirostres, Pygarrhici, Gregarii, Ill. Tenuirostres,

Conirostres, Cuv. Latr. Anerpontes, Epopsides, Vieill.

Anerponti, Epopsipi, Ranz. Order Anisodactyli, Temm.

BiLl elongated, or moderate, subarched, subulate-filiform, entire, acute, or cuneate at tip : tongue short, not extensible. FEET moderate; tarsus annulated, naked; hind toe generally longer and more robust than the others; outer flattened, united at base to the middle one: nails long, incurved. Wings moderate, never acute.

Solitary. Feed on insects, which the greatest part pick out from holes and fissures of trees. Build generally in hollow trees, or cleft rocks, hardly constructing a nest. Some climb on a vertical surface with admirable facility, by means of their robust, acute nails. Incapable of being domesticated, though quite familiar when at liberty, permitting a very near approach. Voice unpleasant.

Allied to the Sagittilingues by the genera Sitta, Dendrocolaptes, and even Certhia ; and to the Egithali by the genus Sitta; but, as a whole, connects admirably the Canori and the Anthomyzi.

\section{CERTHIA.}

Certhia, L. Gm. Lath. Briss. 1ll. Cuv. Temm. Vieill. Ranz.

Bilc shorter than the head, arched, entire, compressedtrigonate, extremely slender, acute : nostrils basal, placed in grooves, half closed by a small membrane: tongue cartilaginous, acute and horny at tip. FEet slender; tarsus longer than the middle toe; inner free and somewhat shorter than the outer; hind toe more robust and longer than the others: nails slender, elongated, incurved, compressed, very acute; that of the hind toe largest. WINGS short; spurious feather short; third and fourth primaries longest; first shorter than 
the seveuth. Tall cuneiform, composed of twelve feathers, elastic, rigid and acuminate.

Female and young hardly differing from the male. Moult annually.

Solitary, or in families or small flocks; frequenting woods and orchards. Climb upwards and downwards on the trees, the rigid tail serving as a support. Feed exclusively on insects, their larvæ and eggs, which they seek for in the crevices and mosses of the bark. Lay twice a year in hollow trees; eggs from three to nine.

Species few, but widely disseminated. Closely allied to the following family, species of which formed part of it as constituted by Linnè, \&c. Intimately allied to the Canori by some North American species of the genus Troglodytes.

151. Cerrthia familiaris, L. Dark-cinereous, varied with whitish, brown and fuscous; beneath white; rump and tail rusty-brown.

Brown Creeper, Certhia familiaris, Wils. Am. Orn. $i$. p. 122. pl. 8. fig. 1 .

Inhabits the north of both continents; more common in Europe and in the western and northern states, than in Pennsylvania, which it visits only in the autumn and winter.

\section{SITTA.}

Sitta, L.Briss. Gm. Lath. 1ll. Cuv. Temm. Ranz.

Sitta, Neops, Vieill.

BiLc moderate, very hard, conic-subulate, subrounded, a little compressed, straight, cuneate at tip; edges sharp; mandibles equal, lower generally recurved from the middle : nostrils basal, orbicular, open, half closed by a membrane, usually covered by setaceous incumbent feathers: tongue short, cartilaginous, depressed and wide at base, emarginatelacerated and horny at tip. FEET robust; hind toe stout, elongated, with a very robust, aduncate, acute nail. Wings 
moderate; spurious feather short ; second, third and fourth primaries longest. TAIL rather short, of twelve feathers broad aud rounded at tip.

Sexes similar: young differing but little from the adult. Moult once a year.

Participate in the habits of the Pici, of the Certhiæ, and of the Pari. Dwell in woods : climb the trunk and branches of trees, both ascending and descending. Feed principally on insects and larva, which they extract from trees in the manner of the Woodpeckers; when pressed by hunger perforate nuts and fruits with their bill. Build in hollow trees; eggs numerous.

Inhabit all cold and temperate countries. Closely related to Parus, from which the Anthomyzi ought not to separate them.*

152. Sitta carolinensis, Briss. Plumbeous; head and neck above black; beneath pure white; vent light ferruginous; lateral tail feathers black and white.

Young, head plumbeous.

White breasted black-capped $\mathcal{N}$ uthatch, Sitta carolinensis, Wils Am. Orn. i. p. 40. pl. 2. fig. 3.

Inhabits throughout North America : common : resident.

153. Sitra canadensis, L. Plumbeous; head and neck above, and line through the eye, black; beneath rusty; lateral tail feathers black and white.

Young, head plumbeous.

White-breasted black-capped Nuthatch, Wils. Am. Orn. $i$. p. 40. pl. 2. fig. 4 .

*Authors disagree respecting the collocation of this genus. Cuvier and Illiger, attending only to the character of the bill, place it near Sturnus; but almost all other authors, with much more propriety, arrange it with Dendrocolaptes and Certhia, between which genera its natural station seems to be. 
Inhabits throughout the union : less common than the preceding species : migratory.

154. Sitta pusilla, Lath. Plumbeous; head and neck above light brown; beneath dull white; lateral tail feathers black, tipped with slate, and crossed with a streak of white.

Brown-headed Nuthatch, Sitta pusilla Wils. Am. Orn. ii. p. $105 \cdot$ pl. 15. fig. 2 .

Inhabits the southern states: rather common: resident.

\section{FAMILY XII. ANTHOMYZI.}

Anthomyzi, Vieill. Ranz. Suspensi, Tenuirostres, Ill. Tenuirostres, Cuv. Latr. Order Anis dactyli, Temm.

BiLL elongated or moderate, slender, entire, very acute, or tuhulous at tip: tongue long, slender, fibrous, extensible. FEET short, or moderate, slender; tarsus annulated, naked, or half feathered; hind toe slender, shorter than the inner; the latter united at base to the middle one. TAIL of ten or twelve feathers.

Moult semi-annually. Plumage generally brilliant.

Feed chiefly on the nectar of flowers, which they suck by means of their long and extensible tongue; some species also partly on insects. Some construct their nest with much art, and lay several times a year. Generally no voice. Difficult to domesticate.

\section{TROCHILUS.}

Trochilus, L. Gm. Luth. Ill. Cuv. Temm. Vieill. Ranz. Polytmus, Mellisuga, Briss. Trochilus, Orthorhyncus, Lacep. Dum. Dumont.

Bill elongated, incurved, recurved or straight, (3 subg.) slender, rounded, depressed at base where it is as wide as the front, acute at tip; edges of the upper mandible covering the lower, the bill thus forming a tube; mouth very small: nostrils basal, linear, covered behind by a turgid membrane: tongue greatly elongated, very extensible, entire at base, 
divided into two filaments from the middle to the tip. FeET very short; tarsus slender, shorter than the middle toe, generally more or less feathered; fore toes almost entirely divided; hind toe somewhat larger than the middle one: nails short, much incurved and retractile, compressed, acute; hind one often shorter than the others. WINGs very long, acute; first primary falcate, longest, the others regularly decreasing. Talc almost always composed of ten feathers.

Differ considerably in appearance according to age, sex, and season. Colours exceedingly brilliant, like those of metals and precious stones.

Solitary. Flight extremely rapid; whilst feeding remain stationary in the air, by means of the horizontal motion of their wings. Produce a humming sound in flight. Walk with difficulty; alight and sleep only on large limbs. Nest attached to a branch or a leaf, hemispherical or conic, lined with down, and covered externally with lichen; eggs two, whitish.

Peculiar to America; almost exclusively tropical.

\section{SUBGENUS MELLISUGA.}

Mellisuga, Briss. Orthorhyncus, Lacépéde.

Bill straight.

155. Trосніцus colubris, L. Golden-green; tail forked, black; three outer tail feathers ferruginous-white at tip.

Male, throat ruby. Female and young, throat whitish.

Humming-bird, Trochilus calubris, Wils. Am. Orn.ii.p. 26. pl. 10. fig. 3. male. fig. 4. female.

Inhabits the United States in summer; winters in Mexico, the West Indies and South America : common.

FAMILY XIII. AGITHALI.

Passerini, Canori, Ill. Dentirostres, Conirostres, Cuv.Latr. Fithali, Antriades, Vieill. Egitali, Ranz.

Orders Granivores, Insectivores, Temm. 
BiLl short, rather robust, straight, compressed, conicsubulate : nostrils basal, half closed by a membrane, and covered by small incumbent feathers. FeET rather robust; tarsus annulated, naked; outer toes united at least to the base; hind toe and nail largest. TAIL of twelve feathers.

Lively and active; live in woods and on trees; suspend themselves by the claws to the underside of the branches, some climbing up and down. Feed chiefly on insects, and sometimes on fruits. Breed usually in holes of trees; very few build skilfully; eggs numerous. Voice unpleasant.

Remotely distinct from the Anthomyzi. But these being taken out of the linear series, connects beautifully the Tenuirostres, by Sitta, to the Passerini.

\section{PARUS.}

Purus, L. Briss. Gm. Lath. 1ll. Cuv. Vieill. Temm. Ranz. Parus, EEgithalus, Mystacinus, Boie.

BILL short, straight, robust, conic-subulate, compressed, entire, acute, with bristles at base; upper mandible longer, rounded above, slightly curved : nostrils basal, small, rounded, concealed by the small incumbent frontlet feathers: tongue truncated and quadrifid at tip, or entire and acute. FEET rather robust ; tarsus a little longer than the middle toe; lateral toes subequal; inner free; outer hardly united at base to the middle one; hind toe more robust : nails rather large, much compressed and acute; hind one largest. Wings moderate; spurious feather short or moderate; second, third, fourth and fifth primaries, subequal and longest.

FeMaLe and young generally differing but little from the adult male. Moult annually. Plumage long, slender.

Familiar; agile; inquiet; leaping irregularly from branch to branch, from which they often suspend themselves. Live in families, in woods and orchards, sitting on trees or marsh weeds. Feed on grains, fruits, insects and their larvæ, in search of which they sometimes injure the buds of trees; perforate seed vessels to obtain the grain; some 
feed also on flesh, often perforating the skulls of sickly birds, even of their own species, and eat the brain. Pugnacious; attacking much larger birds, and often killing weaker ones; defend their young courageously. Breed once a year; eggs numerous, in some species eighteen or twenty. Voice unpleasant, garrulous. Flesh bitter, unpalatable. Easily tamed, and fed with cheese and nuts in the aviary.

Inhabit all climates, except South America.

156. Parus bicolor, L Crested; plumbeous; beneath whitish; flanks tinged with dull reddish-orange.

Crested Titmouse, Parus bicolor, Wils. Am. Orn i. p. $13 \%$ pl. 3. fig. 5 .

Inhabits North America as far north as Greenland : rather rare in Pennsylvania; more common in northern regions.

15\%. Parus articapillus, L. Not crested; plumbeous; crown, cervix and throat black; cheeks and beneath whitish; tail two inches long.

Young, crown dirty brownish.

Black-capt Titmouse, Parus atricapillus, Wils. Am. Orn. i. p. 134. pl. 8. fig. 4 .

Inhabits the continent of North America; more common in the northern regions: common. Exceedingly allied to Parus palustris of Europe.

\section{FAMILY XIV. PASSERINI.}

Passerini, Ill. Conirostres, Dentirostres, Cuv. Latr. Granivores, Pericalles, Canori, Vieill. Conoramfi, Ranz. Order Granivores, Temm.

BiLl short, robust, conic, slightly curved at tip; edges generally entire: nostrils basal. FEeT moderate; tarsus rather slender, annulated, naked; inner toe free; outer free, or united at base only : nails moderate, compressed, incurved, acute. Wings rather short. TaIL of twelve feathers. 
Moult annually. Some have rich colouring in the spring, and assume the humble dress of the female in autumn.

Granivorous; separating the grain from its envelope: some feed occasionally on insects, and nourish their young with them. Few build very skilful nests. Generally migratory in the temperate climates of North America and Europe: some migrate in large flocks in autumn. Many sing well. Flesh generally palatable.

Allied to the Egithali by the genus Parus; but much more intimately to the Gregarii, which exhibit an insensible passage, by the short thick-billed Icteri, to Fringilla.* Intimately related also to the Canori by Alauda, which is so closely allied to Anthus, that no natural series ought to separate them.

\section{ALAUDA.}

Alauda, L. Briss. Gm. Lath. Ill. Cuv. Temm. Vieill. Ranz.

BiLL rather short, somewhat robust, straight, conic-attenuated, acute, with briștles at base; upper mandible convex, entire; lower hardly shorter, compressed: nostrils basal, oval, with an arched membrane, covered by the porrect feathers of the frontlet: tongue cartilaginous, bifid. TARSUS not very slender, longer than the middle toe ; toes free; hind toe thickest, and nearly equal to the outer : hind nail nearly straight, acuminate, generally longer than the toe. WiNGS moderate; spurious feather very short; second and third primaries longest; first and fourth subequal; secondaries emarginate at tip; two of the scapulars nearly as long as the primaries. Tall generally emarginate.

* The African genus Ploceus is another link between the two families, as it may be placed with equal propriety in either, though, on account of its habits, we, with Vieillot, place it in Gregarii.

TOL. II. 
Fenale and young hardly different from the adult male. Moult annually. Feathers of the head more or less erectile.

Live in flocks ; build and dwell almost exclusively on the ground; eggs, 4-6. Feed on seeds, herbs, rarely on insects : fond of dusting themselves. Fly well : run rapidly: tail motionless. Suspend themselves aloft in the air, singing sweetly. Flesh excellent.

Widely spread over the globe.

158. Alauda alpestris, L. Reddish-drab; beneath whitish ; a broad patch on the breast and under each eye, and lateral tail feathers, black; two outer exteriorly white.

Shore Lark, Alauda alpestris, Wils. Am. Orn. i. p. 85. pl.5. fig. 4 .

Inhabits the north of both continents ; much more common and migrating farther south in America : only a winter visitant in the southern and middle states.

\section{EMBERIZA.}

Emberiza, L. Briss. Gm. Lath. Ill. Cuv. Temm. Ranz. Emberiza, Passerina, Vieill.

BiLl short, robust, conic, somewhat compressed, entire ; margins narrowed in, and near the base, a little angular; upper mandible rounded above, acute, smaller and narrower than the lower; palate with a longitudinal bony tubercle; lower mandible rounded beneath, very acute : nostrils basal, small, rounded, open, partly covered by the frontal feathers : tongue thick, divided at tip. Tarsus about equal to the middle toe; lateral toes equal; outer united at base to the middle one ; hind toe hardly thicker than the fore toes and as long as the lateral. Wings moderate; first primary almost equal to the second and third, which are longest. TaIL even or emarginate.

Female differ from the male. Young resemble the female, but darker and more deeply spotted. European and North American species moult annually. 
Live in pairs or in small families. Feed on farinaceous seeds and sometimes insects, which they kill with their bill previously to swallowing them. Build in low bushes and grass; breed several times a year; eggs, 4-6. Song limited.

Widely spread in temperate countries.

SUBGENUS PLECTROPHANES.

\section{Genus Plectrophanes, Meyer.}

Hind nail long and almost straight. Palatine tubercle obtuse, not very conspicuous. First and second primaries longest.

Though moulting but once a year, differ much in plumage from season, owing to the tips of the feathers wearing away.

Live in open countries, plains, mountains, and desert regions, never in forests or thickets. Run rapidly. Resemble Alauda by the hind nail and habits : connect Emberiza with Fringilla, by Spiza.

159. Emberiza mivalis, L. Primaries white, six outer ones exteriorly black; tail black, three lateral feathers white at base.

Male in full dress, head, neck, and beneath white.

Female, young, and male in winter dress, the white parts tinged with rufous.

Snow-bunting, Emberiza nivalis, Wils. Am. Orn. iii.p. 36 . pl. 21. fig. 2. female in winter dress.

Inhabits northern regions of both continents, to the pole; breeds in the arctic circle; rare, and wintering only in the middle states.

\section{TANAGRA.}

Tanagra, L. Gm. Lath. Ill. Cuv. Temm. Ranz. Tangara, Briss. Nemosia, Tanagra, Saltator, Ramphocelus, Pyranga, Tachyphonus, Vieill. 
Biul short, robust, hard, conic-compressed, trigonate and somewhat depressed at base; upper mandible obtusely carinated, curved and notched at tip, longer and wider, and overhanging the lower; lower somewhat turgid towards the middle, with the edges inflexed: nostrils basal, lateral, rounded, open, partly covered by the frointlet feathers: tongue short, cartilaginous, acute, bifid at tip. Tarsus rather longer than the middle toe; inner rather shorter than the outer, which is united at base to the middle one; 'hind toe robust, equal in length to the inner; hind nail largest. WI moderate; three first primaries subequal, longest.

Female and young difier extremely from the male, in full plumage, which is subject to extraordinary changes, according to the season. Moult semi-annually : colours very brilliant.

Active : incautious. Solitary or in families: reside in woods and dry places. Feed indifferently on "seeds, berries, and insects, which latter they take on the wing, or seek carefully among the branches of trees. Build on trees of middling height. Abrupt in their motions : seldom descending to the ground, and then proceeding by hops: flight brisk. Voice not modulated, unpleasant.

Peculiar to America; chiefly between the tropics.

By the relations of some of the species, passes into many other genera, such as Fringilla, Muscicapa, Lanius, Icterus, Quiscalus, Vireo, and even Sylvia; and may be divided into six subgenera or sections, of which but one is found, during summer, within the limits of the United States.

SUBGENUS PYRANGA.

Tangaras Cardinals, Cuv-Genus Pyranga, Fieill.

Upper mandible with an obtuse tooth each side, near the middle. 
160. Tanagra rubra, L. Red; wings and emarginate tail black; base of the plumage ash, then white.

Female, young and autumnal male, green; beneath yellow; wings and tail blackish.

Scarlet Tanager, Tanagra rubra, Wils. Am. Orn. ii. p. 42. pl. 11. fig. 3. male, fig. 4. female.

Inhabits, during summer, all North America, where it breeds; winters in tropical America.

161. TaNigra enstivi, Gm. Red; inner vanes and tips of the quill feathers dusky; tail even.

Female, young, and autumnal male, yellow-olive.

Summ Red-bird, Tanagra astiva, Wils. Am. Orn.i. p. 95. pl. 6. fig.3. male, fig. 4. female.

Inhabits the southern and middle states during summer: rare in the latter; common in the southern and south-western, Mexico, \&c.

162. TANagra LUdoviciana, Wils. Greenish-yellow; anterior part of the head light scarlet; back, wings, and tail, black; wings bifasciate with yellow.

Louisiana Tanager, Tanagra ludoviciana, Wils. Am. Orn. iii, $p, 27 . p l$. 20. fig. 1 .

Inhabits territories beyond the Mississippi, in the extensive plains of Missouri, between the $O$ sage and Mandan nations.

\section{FRINGILLA.}

Fringilla, Loxia, Emberiza, L. Gm. Lath. Fringilla.Ill. Cuv. Temm.Ranz. Carduelis, Passer, Coccothraustes, Hortulanus, Briss. Coccothraustes, Fringilla, Linaria, Passerina, Arremon, Pipilo, Vieill.

BILL' short, robust, conic on all sides, usually entire ; upper mandible wider than the lower, somewhat turgid, a little inclined at tip; edges of the lower angular towards the base: nostrils basal, rounded, open, covered by the frontlet 
feathers : tongue thick, cylindrical, acute, compressed and bifid at tip. FeET moderate; tarsus shorter than the middle toe; toes free; lateral toes subequal; hind toe hardly shorter than the inner; hind nail largest. Wings rather short ; first and second primaries but little shorter than the third or fourth, which is longest.

Female differ from the male principally in the breeding dress. Young, after the first season, resemble the adult. European and North American species chiefly moult once a year.

Live in woods, bushes, and orchards ; alighting generally on the branches of trees, sometimes on the ground; travel in flocks. Breed in trees and thickets; have several broods annually. Many excel in song: easily tamed and kept in cages. Flesh good.

Spread all over the earth.

I divide them into four subgenera, which, however, pass insensibly into erch other.

$\$ 1$. Palate rather prominent, sometimes with the rudiment of a tubercle.

SUBGENUS. 1. SPIZA.

Spiza, Nob. Obs. Nom. Wils. Orn.

Genera Passerina, Fringilla, Emberiza, Vieill.

Edges of the lower mandible narrowed in.

Connects Fringilla with Emberiza, especiallyPlectrophanes, by the greater part of the species, and with Tanagra by a few, which might perhaps constitute a subgenus by themselves. + Species forming the passage to Tanagra. Bill subincurved.

163. Fringilda amana, Nob. Verdigris-blue; beneath white; breast pale ferruginous; wings bifasciate with white; bill notched.

Lazuli Finch, Fringilla amona, Nob. Am. Orn. i. p. 61. pl.6. fig.4. Kimberiza amana, Say. 
Inhabits near the Rocky Mountains, in summer: rare.

164. Fringilda cravea, Wils. Blue; wings and tail-feathers black, edged with blue.

Female, light flaxen, beneath and cheeks clay colour.

Young and autumnal male, like the female, but more or less tinged with bluish.

Indigo-bird, Fringilla cyanea, Wils. Am. Orn. i.p. 100. pl. 6. fig.5. male; and Nob. Am. Orn. ii. pl. 11. fig.3. female.

Inhabits all the United States during summer; common: winters in Mexico.

165. Fringilla ciris, Temm. Red; head and neck above purplish-blue; back yellowish-green; wings dusky red; lesser coverts purple; greater, and tail, green.

Female and young of the first season (the latter changes gradually until the fourth or fifth year), green-olive; beneath naples yellow.

Painted Bunting Emberiza ciris, Wils. Am. Orn. iii, p. 68. pl. 24. fig. 1. male, fig. 2. female.

Inhabits the southern parts of the United States during summer; common in Louisiana and Georgia; rare in North Carolina.

†† Species forming the passage to Emberiza.

166. Fringilda americana, Nob. Breast, line over the eye and 3 the lower angle of the bill, yellow; chin white; throat with a black patch.

Female, without the black patch.

Black-throated Bunting, Emberiza americana, Wils. Am. Orn. i. p. 54. pl. s. fig. 2.

Emberiza americana and Fringilla flavicollis, Gm. Lath.

Inhabits the United States in summer : common.

167. Fringilla leucophris, Temm. Head white, line surrounding the crown and through each eye black; beneath pale ash; vent pale ochreous.

White-crowned Bunting, Emberiza leucophrys, Wils. Am. Orn. iv. p. 49. pl. 31. fig. 4 . 
Inhabits the northern and middle states during winter: rare : common at Hudson's Bay.

168. Fringilla grammaca, Say. Head striped with black and white; tail rounded, lateral feathers partly white.

Lark Finch, Fringilla grammaca, Nob. Am. Orn. i. p. 4\% pl. 5. fig. 2 .

Inhabits the western regions between the Mississippi and the Rocky Mountains; and Mexico.

169. Fringilla pensyevairica, Lath. (15.) Head striped with black and white; a yellow line from the eye to the nostrils; cheeks and breast cinereous; throat and belly white.

White-throated Sparrow, Fringilla albicollis, Wils. Am. Orn. iii. p. 51. pl. 22. fig. 2 .

Inhabits the middle and southern states in winter; more frequent to the north : common.

170. Fringilla graminea, Gm. Breast and flanks spotted with brown; lesser wing-coverts bright bay; two outer tail feathers partly white.

Bay-winged Bunting, Emberiza graminea, Wils. Am. Orn. iv. p. 51.pl. 31. fig. 5 .

Inhabits throughout the Union; wintering in the southern states; common.

171. Fringrlla melodia, Wils. Crown dark chesnut, diyided by a dirty white line; breast and flanks spotted with blackish; tail rounded; first primary shorter than the second.

Song Sparrow, Fringilla melodia, Wils. Am. Orn. ii. p. 25. pl. 16. fig. 4. Fringilla fasciata? Gm. (16.)

Inhabits throughout the Union; common : the greater part resident in the middle states; only during winter in the southern states.

172. Fringilla Savania, Wils. Eye-brows and auriculars yellow ; breast and flanks spotted with blackish ; tail emarginate ; first primary equal to the second. 
Savannah Finch, Fringilla savanna, Wils. Am. Orn. iv. p. 72. pl. 34. fig. 4. male; and iii. p. 55. pl. 22. fig. 3. female.

Inhabits near the Atlantic coast from Savannah to NewYork : common : resident.

173. FringiLta hyemalis, L. nec auct. Blackish; belly, and lateral tail feathers, white; bill whitish.

Snow-bird, Fringilla nivalis (hudsonia), Wils. Am. Ora. ii. p. 129. pl. 16. fig. 6 .

Inhabits throughout the Union, during winter; very common : retiring north in summer.

147. Fringirla passerina, Wils. Breast pale ochre; line from the nostrils over the eye, shoulder, and lesser coverts, yellow; tail feathers subacute, outer partly whitish.

Yellow-winged Sparrow, Fringilla passerina, Wils. Am. Orn. iii. p. 76. pl. 24. fig. 5. Fringilla savanarum? Gm. Lath. Fringilla caudacuta? ? Lath.

Inhabits during summer in the middle and northern states: rather rare.

175. Fringilla canadensis, Lath. Crown reddish-chesnut; stripe over the eye, sides of the neck, chin and breast, pale ash; wings bifasciate with white; bill black, lower mandible yellow.

Tree Sparrow, Fringilla arborea, Wils. Am. Orn. ï. p. 123. pl. 16. fig. 3. Fringilla monticola, $\mathbf{G m}$.

Inhabits arctic America, wintering throughout the Union: common.

167. Fringitla socialis, Wils. Frontlet black; crown chesnut; chin and line over the eye, whitish; breast and sides of the neck, pale ash ; bill entirely black.

Chipping Sparrow, Fringilla socialis, Wils. Am. Orn. $\ddot{i}$, p. 127. pl. 16 fig. 5 .

Inhabits the middle and northern states; passes to the southern in winter.

VOL. II. 
177. Fringinla pusirla, Wils, Crown deep chesnut, with drab streak; cheeks, line over the eye, throat and breast, brownish clay; bill reddish-cinnamon.

Field Sparrow, Fringilla pusilla, Wils.Am. Orn. ii.p. 121. pl. 16. fig. 2 .

Inhabits, during summer, the middle and northern states; winters in the southern: common.

168. Fringlela palustris, Wils. Front black; crown bay; a whitish spot between the eye and nostril; sides of the neck, and breast, dark ash; tail emarginate, lobes rounded; bill dusky, lower mandible bluish.

Swamp Sparrow, Fringilla palustris, Wils. Am. Orn。 iii. p. 49. pl. 22. fig. 1. adult male.

Inhabits swamps and river shores; during summer in the northern and middle states ; winters in the southern : common.

179. Fringilla caudacuta, Wils. nec Lath. Two stripes of brownish-orange each side of the head; breast pale buff with small black spots; tail cuneiform, feathers acute.

Sharp-tailed Finch, Fringilla caudacuta, Wils. Am. Orn. iv. p. 70. pl. 34. fig. 3. Oriolus caudacutus, Gm. Lath.

Inhabits the sea-coast from New-York to Georgia ; not rare.

180. Fringilla maritima, Wils. Streak over the eye, and edge of the shoulder, yellow; breast cinereous; tail cuneiform; bill elongated.

Sea-side Finch, Fringilla maritima, Wils. Am. Orn.iv. p. 68. $p l$. 34. fig. 2 .

Inhabits marshy grounds on the Atlantic coast; rather common. The last three species, but especially the two latter, have a peculiar form and general habit, which might entitle them to a separate subgenus or section. 


\section{$\$ 2$. Palate scooped and grooved.}

SUBGENUS II. CARDUELIS.

Carduelis, Linaria Cuv. Section Longicones, Temm.

Genus :arduelis, Briss. Genera Fringilla, Linaria, Vieill.

Bill subelongated, narrower than the head, straight, compressed : both mandibles acute.

181. Fringilla tristis, L. Wings black, varied with white; tail feathers black, interiorly white at tip.

Male, in summer dress, yellow; crown black.

Female, young, and autumnal male, brown-olive ; beneath yellowish-white.

Yellow-bird or Goldfinch, Fringilla tristis, Wils. Am. Orn. i. p. 20 l. 1. fig. 2. adult male in summer dress; and $\mathcal{N o b}$. Am. Orn. i. p. 5\%. pl. is. fig. 4. female.

Inhabits the United States, Mexico, and South America, extending northward to the Arctic regions; generally leaves the northern and middle states during winter : common.

182. Fringilla psaltria, Say. Olivaceous; beneath wholly yellow; crown, wings 'and tail, black; wings varied with white; three outer tail feathers white on the middle of the inner web.

Arkansaw Siskin, Fringilla psaltria, Nob. Am. Orn. i. p. 54. pl. 6. fig. 3. male.

Inhabits Missouri and Arkansaw.

183. Fringilda pinus, Wils. Flaxen, streaked with black; wings bifasciate with cream colour; shafts of the wing feathers rich yellow; lateral tail feathers yellow at base.

Pine Finch, Fringilla pinus, Wils. fim. Orn. ii. p. 133. pl. 57. fig. 1. winter plumage.

Inhabits the northern regions; a visitant in the middle and southern states, during winter: rare. 
184. Frivgilua linaria, L. Dusky-gray; beneath whitish; frontlet and chin black; head, neck, and rump (in perfect males), tinged with crimson; wing and tail feathers blackish, margined with whitish.

Lesser Red-poll, Fringilla linaria, Wils. Am. Orn.iv. p. 42. pl. 30. fig. 4. male; and ix. p. 126.

Inhabits the north of both continents ; visiting the temperate climates in winter; rare in Pennsylvania, but in some years appearing in large flocks.

Pyrgita, Fringilla, Vidua, Cuv. Genus Passer, Briss. GenusFringilla,Vieill. SectionsBrevicones, Laticones, Temm. Bill short, narrower than the head, perfectly conic.

185. Fringilla iliaca, Merrem. Mottled with reddish-brown and cinereous; beneath white, with large reddish-brown blotches; tail bright ferruginous.

Fox-coloured Sparrow, Fringilla rufa (ferruginea), Wils. Am. Orn. iii. p. 53. pl. 22. fig. 4 .

Inhabits the northern regions; visiting the middle and southern states in winter : common.

186. Fringilla erythrophthalma, L. Black; belly white; flanks and vent bay; tail rounded, three outer feathers partly white; bill black.

Female, reddish-brown where the male is black.

Towhe Bunting, Emberiza erythrophthalma, Wils. Am. Orn. ii. p. 35. pl. 10. fig. 5. male; and vi. p. 90. pl.53. fig. 5. female.

Inhabits throughout the Union during summer; wintering also in the southern states: common. Somewhat anomalous. (17.) 
SUBGENUS IV. COCCOTHRAUSTES.

Coccothraustes, Cuv. Loxia, L. Gm. Lath. Genus Cocsothraustes, Briss. Vieill. Section Laticones, Temm.

Bill very robust, at base as wide as the front, slightly curved at tip, more or less turgid on the sides.

187. Frivgidza cardinalis, Nob. Crested, red, beneath brighter; capistrum and throat black; bill red.

Female and young, drab; beneath reddish-drab; tip of the crest, wings and tail, red; capistrum and chin, light ash.

Cardinal Grosbeak, Loxia cardinalis, Wils. Am. Orn. ii. p. 38. pl. 11. fig. 1. male, fig. 2. female.

Inhabits from New-England to Carthagena, and in the West Indies; more numerous east of the Alleghanies : common and resident in the southern states, and in the lower parts of Pennsylvania.

188. Fringilla vespertina, Cooper. Front and line over the eye, yellow ; crown, wings and tail, black; secondaries and inner great coverts, white; bill yellow.

Evening Grosbeak, Fringilla vespertina, Nob. Am. Orn. ii. pl. 14. fig. 1 .

Inhabits the North-western Territory and Canada.

189. Fringilla ludoviciana, Nob. Black; breast and inferior wing-coverts rosaceous; belly, band on the wing, base of the primaries, and three outer tail-feathers partly, white; bill white.

Female and young, varied with pale flaxen, dark olive, and whitish; no rose colour, and less white on the wings.

Rose-breasted Grosbeak, Loxia rosea (ludoviciana), Wils. Am. Orn. ii. p. 135. pl. 17. fig. 1. male; and Nob.Am. Orn. ii. p. 14. fig. 2. female. 
Loxia ludoviciana,L.Gm.Lath. Fringilla punicea, Gm. Lath.

Inhabits the northern states, and occasionally in winter, the middle: rare.

190. Fringlula carulea, Nob. Blue; lores, frontlet, wings and tail, black; wings skirted with chesnut; bill bluish.

Blue Grosbeak, Loxia carulea, Wils. Am. Orn. iii.p. 17. pl. 24. fig. 6 .

Inhabits America from Brazil to Virginia ; visits Pennsylvania occasionally in summer: rare.

191. Fringilla purpurea, Gm. Rosaceous; back streaked with dusky; belly white; tail emarginate.

Female and young, brown-olive, streaked with dusky; no rosaceous ; beneath whitish, streaked with olive-brown.

Autumnal male, the same as the female, but the rump strongly tinged with yellow.

Purple Finch, Fringilla purpurea, Wils. Am. Orn. i. p. 119. pl. \%. fig. 4. adult male in full plumage; and v.p. $8 \%$ pl. 42. fig. 3. male in winter plumage.

Inhabits the United States, during winter; breeds in the North of America, whence they arrive in Pennsylvania in large flocks, in the autumn, and return from the south in April : rather rare. Hardly belonging to the present subgenus, but rather to Fringilla; placed here however on account of its close affinity to the following species of Pyrrhula.

\section{PYRRHULA.}

Loxia,L. Gm. Lath. Fringilla, Ill. Meyer (subg. Pyrrhula). Pyrrhula, Briss. Temm. Ranz. Fringilla (subg. Pyrrhula), Corythus, Cuv. Pyrrhula, Strobilophaga, Vieill.

BucL very short, robust, conic-convex, turgid ; upper mandible rather rounded above, dilated each side so as to cover 
the margins of the lower, acute and much incurved at tip; palate smooth and scooped; lower mandible shorter, straight, rather obtuse: nostrils basal, lateral, small, rounded, entirely or partially covered by the incumbent feathers of the frontlet: tongue thick, somewhat fleshy, rather obtuse, entire. Tarsus shorter than the middle toe, which is united at base to the outer; lateral toes subequal; inner hardly longer than the hind one, which is strongest : hind nail largest. Wings rather short, acute; first primary equal to the fifth ; second, third, and fourth longest. TaIL hardly emarginate.

Female differs considerably from the male. Generally moult twice a year.

Live in forests. Feed on seeds, drupes, nuts, which they break, as well as on buds and germs of trees. Build in trees, thickets : lay $4-5$ eggs.

Spread all over the globe.

So closely allied to Fringilla by intermediate species, that it ought perhaps only to be considered as a subgenus.

193. Prrrhula frontalis, Nob. Dusky-brownish; head, neck, breast and rump, vivid crimson; belly whitish, streaked with dusky; tail nearly even.

Female dusky-brown, feathers edged with whitish; no crimson; beneath whitish, streaked with dusky.

Crimson-necked Bull-finch, Pyrrhula frontalis, Nob. Am. Orn. i. p. 49. pl. 6. fig. 1. male, fig. 2. female.

Fringilla frontalis, Say. nec Lath.

Inhabits during summer near the Rocky Mountains. Most closely allied to the preceding as a species, though generically distinct.

193. Pyrrhula enucleator, Temm. Wings bifasciate with white, and with the tail, black, the feathers edged with whitish. 
Adult male, head, neck, and beneath, orange.

Young male, the same parts and the rump, red.

Female, top of the head and rump, brownish-orange; beneath cinereous, slightly tinged with orange.

Pine Grosbeal, Loxia enucleator, Wils. Am. Orn. i. p. 30. pl. 5. fig. 2. young male about one year old.

Inhabits the cold regions of both continents, whence it occasionally visits temperate climates in winter : very rare in Pennsylvania. Forms the link between Pyrrhula and Loxia, to the species of which it is closely allied by its habits, and by its unusual change of plumage.

\section{LOXIA.}

Loxia, Briss. L. Gm. Lath. Ill. Cuv. Temm. Vieill. Ranz.

Crucirostra, Daud. Meyer. Nilson.

Curvirostra, Scopoli. Duméril. Wilson. Brehm.

BILl robust, convex, mandibles crossing each other and compressed towards the tip : nostrils basal, small, rounded, covered by the small, incumbent frontlet feathers: tongue cartilaginous, short, entire, acute at tip. TArsus subequal to the middle toe ; toes divided ; lateral subequal, considerably shorter than the middle one : hind nail largest, much incurved. Wings moderate, acute; first and second primaries longest. TAIL emarģinate.

Female and young differ considerably from the adult male, and from each other; the young also, according to age, and the adult, to season; although they moult but once a year.

Habits similar to those of the Fringillæ and Pyrrhula. Keep principally in pine forests. Feed on nuts, and seeds of trees of the pine family, from the cones of which their singular bill is well formed for extracting them. According to authors, build and reproduce during winter in our 
temperate climates; return to the arctic regions on the approach of summer; migrating at irregular periods, and then appearing in great numbers in certain countries. Agile; not timorous; easily tamed at all ages.

Confined to northern regions.

194. Loxia curvirostra, L. Wings without bands; bill as long as the middle toe; point of the lower mandible crossing the top of the bill.

Adult male greenish yellow; rump yellow.

Female and young before the first moult, greenish; rump yellowish; beneath whitish, streaked with dusky.

Young male after the first moult, red.

American Crossbill, Curvirostra americana, Wils. Am. Orn. iv: p. 44. pl. 31. fig. 1. young male! fig. 2. adult male?

Inhabits the high northern latitudes of both continents; migrates during winter to the northern and middle states, where a few breed : rather common. (18.)

195. Loxia levcoptera, $\mathrm{Gm}$. Wings bifasciate with white.

Different states as in the preceding.

White-winged Cross-bill, Curvirostra leucoptera, Wils. Am. Orn. iv. p. 48. pl. 41. fig. 4. young male; and Nob. Am. Orn. ii. pl. 14. fig. 3. female.

Inhabits the northern parts of America; migrating in winter to the temperate regions of the northern and middle states : rare.

\section{FAMILY XV. COLUMBINI.}

Order Columbr, Lath. Temm. Order Giratores, Blainville. Order Columbini, Stephens. Pigeons (Family of Gallina), Cuv. Columbini, Ill. Vieill. Latr. Girunti, Ranz.

Bicl short, straight, compressed; upper mandible vaulted, more or less attenuated in the middle, turgid and curved at tip, dilated so as to cover the lower, with a soft, fleshy,

Vou. II. 
protuberant membrane, at base : nostrils medial, longitudinal, perforated in the membrane anteriorly : tongue rather short, acute, entire. FEET short, rather robust; tarsi reticulated; toes divided; hind toe twice as long as the inner : nails incurved, acute. Wings moderate. TAIL of twelve or fourteen feathers.

Female generally similar to the male. Young differ considerably before the first moult. Moult annually. Feathers strong.

Live in high trees in woods, or on high buildings, generally in societies. Feed on seeds, principally cereal and leguminous, sometimes on fruit : retain the aliment in the crop, where it is prepared for digestion. The greater part build in elevated situations; nest loose, flat, formed of small twigs, and wide enough to contain both sexes; lay generally two eggs, several times in the year. Feed their young by regurgitating into the mouth the grains macerated in their crop. Pair for life, but congregate in flocks in the autumn. Make a rustling with their wings in the breeding season: male ad. dresses his mate by uttering a peculiar note, by billing, and by various evolutions. Drink at one draught, immerging the bill. No song; voice merely a simple cooing.

Inhabit all climates; species far more numerous in hor countries. Almost equally related to Passeres and Gallinæa

37. COLUMBA.

Columba L. Briss. Gm. Lath. 1ll. Cuv. Temm. Columba, Lophyrus, Vieill. Columba, Vinago, Goüra, Stephens. Ranzani.

SUBGENUS I. COLUMBA.

Genus Columba, Stephens. Ranz.

1. Bill moderately robust, straight, turgid at tip. Tarsi 
wather short. Wings long, acute; first primary somewhat shorter than the second, which is longest.

Live in wooded countries. Build in high trees or in hollow trunks : nest composed of sticks, dried leaves, feathers, \&c. Live in pairs constantly: lay two eggs on which both sexes sit, and afterwards nurse the young. Flight rapid, accompanied with noise.

$$
\text { + Tail short, even, of twelve feathers. }
$$

196. Columba fasciata, Say. Purplish-cinereous; a white band on the nucha; tail with a blackish band near the middle; bill yellow, black at tip.

Band-tail Pigeon, Columba fasciata, Nob. Am. Orn. $i$. p. 77. pl. 8. fig. 3 .

Inhabits the Rocky Mountains near the Arkansaw river.

197. Columba leucocephala, L. Slate-blue; crown white; bill red, whitish at tip.

White-crowned Pigeon, Columba leucocephala, Nob. Am. Orn. ii. pl. 15. fig. 1. female.

Inhabits the West Indies and Mexico, and the Bahama Islands ; an early spring visitor in Florida, where it breeds; common on the Florida keys.

198. Columba zenaida, Nob. Brownish-ash; beneath vinaceous; an amethystine spot under each ear; tail with a black band; three lateral feathers pearl-grey at tip.

Zenaida Dove, Columba zenaida, Nob.Am. Orn. ii. pl. 15. fig. 2. female.

Inhabits the Florida keys early in the spring : rare. (19.)

$$
\text { t† Tail long, cuneiform. }
$$

199. Columba carolinensis, L. Forehead and breast vinaceous ; a black spot under each ear ; tail of fourteen feathers : four lateral black near the tip, and white at tip.

Carolina Pigeon, or Turtle Dove, Columba carolinensis. Wils. Am. Orn. v. p. 91. pl. 43. fig. 1. 
Inhabits the United States during summer; common; wintering chiefly in the southern states.

200. Columba migratoria, L. Bluish-slate; belly white; throat, breast and sides, vinaceous; tail black, of twelve eathers; five lateral whitish.

Female paler; breast cinereous-brown.

Young dull dirty gray, spotted with whitish.

Passenger Pigeon, Columba migratoria, Wils Am. Orn. v. p. 102. pl. 44. fig. 1. male.

Inhabits North America east of the Rocky Mountains, exceedingly numerous : less abundant in the Atlantic states.

SUBGENUS II. GOURA.

Genus Goüra, Stephens. Ranz. Columba, Lophyrus, Vieill. Columbi-Gallina, Le Vaill. Cuv. Temm.

Bill slender, flexible, hardly turgid at tip ; upper mandible furrowed on the sides : nostrils small, orbicular, situated in the furrow. Tarsi rather long. Wings short, rounded, concave; first primary shorter than the fifth; third longest. Tail of twelve feathers.

In structure and habits approach nearer to the Gallinæ than their congeners. The greater number of species keep generally on the ground, where they build. The young of some species are said to run from the nest as soon as hatched, and not to require the care of the parents.

201. Columba passerina, L. Scapulars with dark spots; tail rounded, lateral feathers black, tipped and edged with white; bill black at tip, and with the feet, yellow.

Ground Dove, Columba passerina, Wils. Am. Orn. vi. p. 15. pl. 46. fig. 2. male, fig. 3. female.

Inhabits the southern states, during summer; found also in Mexico and the West Indies : numerous. 


\section{ORDER III. GALLINAE.}

\section{Galline, L. Gm. Lath. Cuv. Temm. Ranz.}

Rasores, Iil. Gallinacei, Vieill. Latr.

BiLL short, hard, convex ; upper mandible vaulted, curved, the margins projecting over the lower : nostrils lateral, half covered by an arched, cartilaginuus, membrane. Head small : neck rather short, thick: body massive, but slightly compressed. FeEt stout, covered by a rough coriaceous skin; tibiæ fleshy, wholly feathered; tarsus short or moderate, rounded; toes thick, moderate, scabrous beneath, three before and generally one behind, articulated with the tarsus higher than the rest, hardly touching the ground at tip; sole callous : nails moderate, somewhat obtuse, convex, but little incurved, not in the least retractile. WINGs generally short, rounded, concave; quills stiff and curved. TAIL of from ten to eighteen feathers, very rarely wanting.

Female: smaller, differing considerably from the male; in most species much less brilliant in plumage. Young at first covered with thick down, gradually replaced by feathers. Moult generally but once in the year. Contains the most beautiful of birds.

Keeping on the ground: scratching the earth: dusting themselves. Granivorous : searching for corn and other seeds, and feeding sometimes on garden vegetables, berries, buds of trees, and insects : macerate their food in their muscular crop ; aiding digestion by means of small stones, \&c. Chiefly polygamous : females alone attending to the nest, incubation, and education, the males of most species hardly assisting : nest on the ground, inartificially composed of a few straws: lay several times in the year; eggs numerous : chicks 
running about as soon as hatched and picking up the food indicated by the mother, and remaining under her charge until autumn, or even the following spring. Run swiftly: take wing with difficulty; flight low, whirring, limited : but very few undertake long periodical journeys. Voice unpleasant, crowing, cackling, or whistling. Flesh edible, gustful food; in domesticity, poultry ; when wild, game. Analogous to Pecora among Mammalia.

\section{FAMILY XVI. GALLINACEI.}

Gallinacei, Ill. Nudipedes, Plumipedes, Vieill. Razzolanti, Ranz. Tetradactyli, Latr.

Bill thick : nostrils basal. Fore 'Toes connected at base by a membrane. Neither hind toe, nor tail ever wanting.

\section{MELEAGRIS.}

Meleagris, L. Gm. Lath. Ill. Cuv. Vieill. Temm. Raßz. Gallopavo, Briss. Cynchramus, Moehring.

BiLL entire, covered at base by a naked, cerelike membrane prolonged into a pendulous, fleshy, conic, erectile, hairy, caruncle : nostrils oblique, situated in the cere : tongue fleshy, entire. HEAD very small, naked, carunculate, as well as half of the neck : throat with a longitudinal, carunculous appendage : a pendulous bristly tuft on the inferior portion of the neck. Feet somewhat elongated. Tarsus naked, clypeate, furnished with an obtuse spur in the male; toes scutellated; hind toe half as long as the lateral equal ones; middle toe much the longest: sole granulated: nails oblong, wide, obtuse rounded above, perfectly plane beneath. Wings not reaching beyond the origin of the tail ; first primary shortest; 
second and ninth subequal; fourth and fifth longest. TaIc of from fourteen to eighteen wide feathers, capable of being vertically expanded.

Female considerably smaller and widely different from the male. Young; at first, similar to the female, destitute of the bristly tuft. Feathers very long, truncated. Colours varying in richness according to the incidence of light.

Gregarious ; forming large flocks. Live generally in forests, roosting on the branches of large trees : noisy at the dawn of day. Feed principally on maize and acorns, also on other vegetable, and even animal, substances. Courting their mates by strutting, puffing, wheeling, \&c.; very pugnacious in the breeding season. Easily secured and domesticated. Flesh exceedingly good and much esteemed.

Peculiar to North America; composed of but two species.

202. Meleagris gallopavo, L. Primaries dull blackish, banded with white; tail of eighteen feathers, ferruginous, skirted with black, and with a black subterminal band.

Male varying from black to refulgent coppery.

Female and young, dusky-gray, with but few metallic reflections.

Wild Turkey, Meleagris gallopavo, Nob. Am. Orn. i. p. 79. pl. 9. male and female.

Inhabits all North America to the Rocky Mountains : common in the western and southern states; nearly destroyed in the eastern and northern: domesticated throughout the world, producing endless varieties.

39. PERDIX.

Perdix, Briss. Lath. 1ll. Vieill. Temm.

Tetrao, L. Gm. Cuv. Perdix, Coturnix, Ranz.

BiLL entire, bare : membrane of the nostrils naked: tongue, fleshy, entire, acute. HEAD wholly feathered; often a naked space round the eye. FEeT naked; tarsus clypeate- 
scutellate; toes scutellated; hind toe less than half as long as the inner: nails somewhat compressed, incurved, and acute. TaIL short, rounded, deflexed, of from twelve to eighteen close feathers.

Femal b but very little smaller and not greatly differing from the male, yet easily distinguished. Young, after the first year, similar to the adult. Moult annually.

Reside in fields among high grasses, stubble, \&c. Not avoiding the proximity of man; attracted by cultivation,

Found all over the world: abounding most in warm and temperate climates, and much pursued as game every where. Composed of four subgenera.

SUBGENUS ORTYX.

Ortyx, Stephens. Colins, Buff. Cuv. Temm. Vieill.

Bill short, thick, higher than wide; upper mandible curved from the base : no naked skin round the eye. Tarsi destitute of spur or tubercle in both sexes. Wings rounded; third and fourth primaries longest. Tail of twelve feathers, longer than the coverts.

Alight on bushes, hiding and roosting in trees. Monogamous: male keeping watch while the female sits, and guiding the chicks carefully, warning them of danger by a cry. Gregarious until the time of pairing.

Peculiar to America, where the other three subgenera have no representatives.

203. Perdix virginiana, Lath. Crestless; cinnamon-browi varied with black and white; throat white banded with black; bill black; feet ash.

Female and young, stripe over the eye and throat, yellowish. Quail, or Partridge, Perdix virginiana, Wils. Am. Orn. vi. p. 21. pl. 47. fig. 2. male.

Inhabits common throughout North America as far as the Rocky Mountains. 
204. Perdix calrfornica, Lath. Crested; cinereous-brown, varied with yellowish; throat black, bounded with white.

Female lighter, destitute of black.

Tetrao californicus, Nat. Misc. tab. 345.

Inhabits, common beyond the Rocky Mountains, especially the shores of the Oregon, and California.

40. TETRAO.

Tetrao, L. Gm. Lath. Ill. Cuv. Temm. Ranz.

Lagopus,Briss. Urogallus,Scopoli. Tetrao,Lagopus, Vieill.

BiLI entire, feathered at base; upper mandible curved from the base; membrane covering the nostrils feathered: tongue short, fleshy, acuminate, acute: eye-brows naked, reddish, papillous. FEET moderate; tarsus feathered, spurless in both sexes; toes scutellate; hind toe half as long as the inner; nails incurved, acute, generally somewhat flat and obtuse. Wivgs short, rounded, concave; first primary shorter than the sixth; third and fourth longest. TaIL moderate, of sixteen or eighteen broad close feathers.

Female of the larger species widely different from the male, these being glossy blackish, whilst the former are varied with black and rufous: those of the smaller mottled species differing but little in plumage. Young of the first year similar to the female, moulting twice before they attain their full plumage. Moult twice in the year ; some changing very remarkably at different seasons.

Wild; shy, almost untameable. Live in families : dwell in forests, barren countries, far from man and cultivation : alight on trees. Feed almost exclusively on berries, buds, and leaves. Polygamous : male abandoning the female as soon as fecundated, and leaving to her the whole care of the progeny: eggs from eight to fourteen. Voice sonorous. Flesh delicious.

VoL. II. 
Confined to the cold and temperate climates of the northern hemisphere.

Tetrao, Vieill, Coqs de bruyères, Cuv. Bonasa, Stephens. Lower portion of the tarsus, and toes naked. Not varying much with the seasons.

Live in dense forests of different kinds of trees.

205. Tetrao unberrus, L. Crested; mottled; tail elongated, rounded, of eighteen feathers, ferruginous, varied with black, and with a black subterminal band; toes pectinated.

Male, sides of the neck with a ruff of large black feathers.

Female and young, ruff smaller, dark brown.

Ruffed Grous, Tetrao umbellus, Wils. Am. Orn. .vi. p. 45. pl. 49. male.

Inhabits common throughout the Union, Canada, and higher northern latitudes, in woody countries, especially mountainous pine districts.

SUBGENUUS II. TETRAO.

Tetrao, Vieill. Coqs de bruyères, Cuv.

Tetrao, Bonasa, Stephens.

Tarsus wholly feathered, toes naked. Not varying much with the seasons.

Found in temperate regions, at even a comparatively low latitude, and in level as well as mountainous districts.

206. Tetrao cupido, L. Subcrested, mottled; tail short, much rounded, of eighteen plain dusky feathers; toes not pectinated.

Male, neck furnished with wing-like appendages, covering two loose, orange, skinny bags, capable of being inflated.

Female and young, destitute of the cervical appendages and skinny bags. 
Pinnated Grous, Tetrao cupido, Wils. Am. Orn. iii. p. 104. pl. 2\%. fig. 1. male.

Inhabits desert open plains in particular districts of the Union, avoiding immense intermediate regions. Found in Maine, New-Jersey, Long-Island, Pennsylvania, Kentucky, Louisiana, Indiana : very common beyond the Mississippi, Missouri, and even on the Oregon.

207. Tetrao obscurus, Say. Slightly crested; tail rounded, blackish, with a broad terminal band of whitish-gray, dotted with black; middle tail feathers mottled, lateral ones plain; toes not pectinated.

Male unknown; probably glossy black?

Female and young, black brown, varied with ochraceous and white.

Dusky Grous, Tetrao obscurus, Say, in Long's Exp. ii.p. 14 . Inhabits the territory of the United States near the Rocky Mountains.

208. Tetrao canadensis, L. Subcrested; blackish; breast, superior and inferior tail coverts, banded with white; tail moderate, slightly rounded, of sixteen plain black feathers; toes not pectinated.

Male blackish, barred with gray-brown : throat black.

Female and young, much lighter and more varied; throat rufous.

Tetrao canadensis, L. (Buff. pl. enl. 131.) male.

Tetrao canace, L. (Buff. pl. enl. 132.) female.

Inhabits the western wilds of the United States beyond the Mississippi, and the north-western part of Maine and Michigan : more common in Canada, at Hudson's Bay, and other high northern latitudes.

209. Tetrá phastanelidus, L. Subcrested; mottled; tail short, cuneiform, of eighteen feathers; two middle ones much the longest; toes strongly pectinated. 
Male, breast chocolate-brown.

Female and young, breast of the same colour with the rest of the body.

Tetrao phasianellus, Say, in Long's exp. (20.)

Long-tailed Grous, Edwards, tab. 117.

Inhabits the western wilds of the United States beyond the Mississippi : very common at Hudson's Bay and in other high latitudes. 
The Genera of Nortir Aurerican Birds, and a Synopsis of the SPEcres found within the territory of the UNITED States; systematically arranged in Orders and Families. By Charles Lucian Bonaparte. Read January 24, 1826.

(CoNTINUED Fron PAGE 128.)

\section{- ORDER IV. GRALLE.}

Gralle, L. Cuv. Latr. Grallé, Galline, Gm. Gralla, Gallina, Struthiones, Pinnatipedes, Palmipedes, Lath. Cursores, Grallatores, Ill. Grallatores, Vieill. Alectorides, Cursores, Grallatores, Pinnatipedes, Temm. Gralla, Ratita, Ranz. Grallatores, Rasores, Vigors.

BiLL generally elongated, sub-cylindrical. FEET elongated or moderate, covered by a tender, coriaceous skin ; tibiæ but partially fleshy, partly naked (subgenera Rusticola and Ardeola excepted*); tarsi generally slender, rounded, naked, reticulated or annulated ; toes disposed 2-0, 3-0, 3-1, either divided, or connected at base by a membrane : nails in no degree retractile. $\mathrm{N}_{\mathrm{ECK}}$ generally long; body compressed; skin very thin. Wings generally long, though occasionally too short for flight; scapulars elongater. TaIL short, of from ten to twenty feathers, very rarely wanting.

Fexale generally similar to the male in plumage. Young generally differing for a time from the adult, with the joints thicker. Some moult twice a year, changing their plumage periodically. But few distinguished by brilliant colors.

* Even in these the character is somewhat preserved by the articulation being exposed.

Vor. II. 
Sad, shy, cunning. Live on the ground, especially along waters, and in marshy places, wading by means of their long legs. Mostly semi-nocturnal. Feed on insects and worms, which they seek in the mud; the larger species also on fishes, and reptiles; a few on weeds and seeds. In breeding various, but only once in the year: the polygamous species build on the ground, and often leave the hatching of their eggs in part to the sun; their young ruming about as soon as hatched, and searching for food under the eye of the mother only: while the monogamous build generally on high trees, and feed their young in the nest until full-fledged. Flight swift, long sustained, the feet stretched out behind. Migrate in large flocks periodically to great distances, crossing seas in search of warmer climates, even different species together, but the young and adult always separately; the latter departing first, and arriving last. Voice harsh, loud, tuneless. Flesh sapid; some species ranked among the most valuable game. Analogous to Belluæ.*

\section{FAMILY XVII. PRESSIROSTRES.}

Pressirostres, Longirostres, Cuv. Latr. Campestres, Iittorales, Limicola, Ill. Pedionomi, Egialites, Helionomi, Vieill. Tachidromi, Limose, Ranz. Charadriado, Vigors.

Bill short or moderate, compressed. Neck moderate. Feet rather short; toes short, 3-0, 3-1; hind toe when present articulated higher on the tarsus than the rest, very short: nails small. Wings moderate or long.

Prefer dry places, sandy beaches, \&c. Run and fly swiftly. Feed principally on insects, mollusca, and other marine animals. Monogamous : lay on the ground: both sexes sit alternately on the eggs: young leave the nest as soon as hatched.

* We think them analogous to Belluæ, though Linnè states them to bc analogous to his Bruta. 


\section{CHARADRIUS.}

Charadrius, Tringa, L. Gm. Lath. Ill. Cuv. Pluvialis, Vanellus, Briss. Charadrius, Vanellus, Temm.Vieill. Ranz.

BiLl shorter than the head, rather slender, straight, cylindrical, depressed at base, obtuse, and somewhat turgid at tip; upper mandible longitudinally furrowed on two-thirds of its length; lower shorter: nostrils lateral, concave, linear, half covered by a prominent membrane : tongue lanceolate, entire, somewhat cylindrical at tip. Head and eyes large: front prominent. FEET 3, or 4-toed, with the hind toe exceedingly small, and elevated from the ground: naked part of the tibia moderate : tarsus clypeate-scutellate; toes scutellate, margined by a narrow membrane; outer toes connected at base by a small membrane: nails compressed, curved, acute. Wings elongated, subacute, tuberculated ; first primary longest. TaIL more or less rounded, of twelve feathers.

Female similar to the male in most species. Young differ somewhat from the adult. Moult generally twice in the year, changing somewhat in color. Some foreign species distinguished by spurred wings, and fleshy appendages on the head or bill.

Gregarious : keep in meadows, or on the sea shore. Stirring the soil with their feet, to put in motion worms and aquatic insects, their exclusive food. Lay in the sand about four large eggs.

Inhabit throughout the world; traversing temperate countries in the spring and autumn.

SUBGENUS I. CHARADRIUS.

Charadrius, L. Gm. Lath. Ill. Cuv. Temm. Vieill. Ranz. Pluvialis, Briss.

Feet three toed; no rudiment of hind toe.

$\dagger$ All the toes connected at base by a membrane. 
216.* Charadrius semipalmatus, Nob. Brownish-ash ; front, collar, and beneath, white; frontlet, and a broad ring around the base of the neck, black; bill and feet orange, the former black at tip.

Adult, sincipital band and auriculars, black.

Young and autumnal, neck-ring dusky; bill wholly blackish.

Ring Plover, Charadrius (Tringa!) hiaticula, Wils. Am. Orn. vii. p. 65. pl. 59. fig. 3. adult in spring dress; and Semipalmated Plover, Charadrius semipalmatus, Nob. Am. Orn. young.

Inhabits common all along the sea coast of the union : retiring to high northern latitudes during summer to breed.

\section{†† Inner toe cleft.}

21\%. Ciraradrius melodus, Ord. Whitish-ash; front, collar and beneath, white; no black on the frontlet; a narrow black ring around the base of the neck; bill and feet orange, the former black at tip.

Adult, a black sincipital band.

Young and autumnal, no neck-ring; no sincipital band; bill entirely blackish.

Ringed Plover, Charadrius hiaticula, Wils. Am. Orn. v. p. 30. pl. 37. fig. 3. adult in spring dress; and Piping Plover, Charadrius melodus, Nob. Am. Orn. autumnal.

Inhabits common all along the eastern sea coast of North America; not migrating as far to the north as the preceding species, and remaining throughout the summer in the temperate regions; departing sooner for the south.

218. Charadrius wilsonius, Ord. Olive-ash; front, collar

* The discovery since the publication of the former part of this paper, of six species to be added to the first three orders, making the entire number belonging to them 215, renders it necessary to number the first species in this order 216. 
and beneath, white; frontlet, and a broad ring around the base of the neck, black; bill black; feet flesh color.

Adult, a black sincipital band.

Young, sincipital band; frontlet and neck-ring, dusky.

Wilson's Plover, Charadrius wilsonius, Wils. Am. Orn.ix. p. 7\%. pl. 73. fig. 5 .

Inhabits the sea shores of the southern and middle states during summer.

219. Charadrius vociferus $L$. Olive-ash; rump orange; front, collar and beneath, white; a broad neck ring and pectoral belt, black; tail cuneiform.

Kildeer Plover, Charadrius vociferus, Wils. Am. Orn. vii. p. 73. pl. 59. fig. 6 .

Inhabits common throughout the union; more numerous during winter in the southern states, though resident in the middle ones.

220. Charadrius pluviatis, L. Mottled with black and goldenyellow; long axillary feathers dingy white.

Summer plumage, beneath black : winter, beneath whitish.

Moulting and young duller; beneath varied with black and whitish.

Golden Pl,ver, Charadrius pluvialis, Wils. Am. Orn. vii. p. $71 . p l .59 . f i$. 5. winter plumage; and Nob. Am. Orn. summer dress.

Inhabits throughout the world; retiring in the summer to the north to breed.

SUBGENUS II. SQUATAROLA.

Squatarola, Cuv. Tringa, L. Gm. Lath. Ill. Vanellus, Briss. Temm. Vieill. Ranz.

Feet four-toed; hind toe exceedingly small.

Connects our genus Charadrius with our genus Vanellus, which has no representative in the United States, and of which authors make it a section. 
221. Charadrius helveticus Nob. Mottled; long axillary feathers black.

Summer plumage, muttled with black and white; beneath black: winter, mottled with black and yellow; beneath whitish. Moulting and young, beneath varied with black and whitish.

Black-bellied Plover, Charadrius apricarius, Wils. Am. Orn. vii. p. 41.pl. 59.fig.4. summerdress; and Swiss Plover, Charadrius helveicus, Nob. Am. Orn. winter plunage. Tringa helvetica, L. Vanellus helveticus, Briss.

Inhabits the north of both continents.

\section{STREPSILAS.}

Tringa, L. Gm. Lath. Arenaria, Briss. Vieill. Strepsilas, Ill. Temm. Ranz. Scolopax (subgenus Strepsilas) Cuv. Morinella, Meyer.

BiLL shorter than the head, robust, hard, straight, conicattenuated, compressed, slightly flattened above, truncated at the point; upper mandible straight, slightly recurved from the middle; lower somewhat recurved at tip: nostrils placed in a short furrow, basal, lateral, oblong-linear, half covered by a membrane, pervious: tongue short, compressed, canaliculate, acute. FEET rather short, four-toed; a very small part of the tibia bare; tarsus not longer than the middle toe, rather robust, scutcllated; toes with a narrow margin, divided to the origin; hind toe touching the ground at tip : nails curved, acute; middle one dilated on the inner margin. WINGs long, acuminate, tuberculated ; first primary longest. Tall rather short, of twelve feathers.

Female similar to the male. Young differing from the adult, and changing repeatedly until the third year. Moult semi-annually.

Solitary: follow the retreating waves: dextrously turn over heavy stones with their bills, and examine carefully every recess in search of their favourite food, marine insects, 
mollusca, \&cc. Male and female remarkably faithful to each other. Lay in sand holes or in the grass; eggs about four. Flight very swift.

Inhabit both continents : composed of but one species.

222. Strepsil as interpres, Ill. Throat, rump, and base of the tail, white; bill black; feet red.

Adult, varied with black, white and ferruginous; breast black; belly white.

Young, cinereous-brown varied with white; breast whitish.

Turn-stone, Tringa interpres, Wils. Am. Orn. vii. p. 32. pl.5\% fig. 1. adult.

Inhabits all parts of the world.

44. H开MATOPUS.

Hamatopus, L. Gm. Lath. Ill. Cuv. Temm. Vieill. Ranz. Ostralega, Briss.

Bill longer than the head, robust, straight, cuneate, and much compressed at tip; upper mandible flattened above to the middle : nostrils basal, lateral, placed in a short furrow, linear, pervious : tongue short, entire: eyelids naked. FEET moderate, three-toed; bare space of the tibia moderate; tarsus somewhat longer than the middle toe, robust, reticulated; toes short, thick, scutulate, (covered with scales) scabrous beneath, colligated, bordered by a rough warty edge; outer 'toes connected at base by a membrane; the inner membrane rudimental : nails short, tile-shaped, curved, acute. WINGS sub-elongated, acute; first primary longest. TAIL slightly rounded, of twelve feathers.

Female similar to the male. Young differing but little from the adult, at first covered with grayish down. Moult twice in the year, the plumage changing slightly, but constantly. Color black, or blackish, with more or less of white.

Shy : solitary, or in small parties. Live on sea shores, rocks, sandy beaches, \&c. Running in and following the 
retreating surf in search of food; probing the mud with their strong and well adapted bill; breaking thin shells, and dextrously removing the animal from hard ones. Laying a few eggs amongst the grass in salt marshes, or in dry sand. Flight swift, vigorous, long continued; collect in large flocks to migrate. Voice loud and shrill.

Found in all quarters of the globe; composed of but three species.

223. Hematopus ostralegus L. Blackish; rump, band on the wing, base of the quills and tail feathers, and from the breast beneath, white; bill and feet red.

Summer pluınage, glossy black : winter, a white crescent on the throat.

Young, back and wings sooty-brownish; bill and feet dusky.

Pied Oyster-catcher, L'cematopus ostralegus, Wils. Am. Orn.

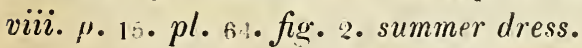

Inhabits the north of both continents.

\section{FAMILY XVII. HERODII.}

Herodii, Ill. Cultirostres, Cuv. Latr. Herodiones, Laiirostres, Arophoni, Vieill. Erodie, Latirostre, Ranz. Gruid a, Ardeida, igors.

BiLL longer than the head, very robust, generally sharp, edges cutting. NECK elongated. FeEt elongated, four-toed; tarsus longer than the middle toe, reticulated; toes $3-1$, and nails, long. WINGs moderate, obtuse. TAIL of ten or twelve feathers.

Female difiering but little, if any, from the male. Young differing much from the adult until the third year.

Gait slow, grave. Flight slow, though light, and elevated. Monogamous : build in trees, thickets, aquatic grasses, sometimes on edifices: female only sits on the eggs, whilst the male watches, and supplies her with food; both sexes nurse and rear the young, which only leave the nest when fullfledged. Flesh unpalatable. 
45. GRUS.

Ardea, L. Gm. Lath. Grus, Pallas. Ill.Cuv. Temm. Ranx. Balearica, Ciconia, Briss. Grus, Anthropoides, Vieill.

BiLu not much cleft, straight, compressed, attenuated at the point, somewhat obtuse at tip ; mandibles subequal, margins vertical, upper convex with a wide furrow on each side at base, obliterated before the middle : nostrils placed in the furrow, medial, concave, elliptical, pervious, posteriorly closed by a membrane; tongue fleshy, broad, acute: ophthalmic region and lora feathered: head generally bald, verrucose, sometimes crested: body cylindrical. Feet long, stout; naked space above the tarsus extensive; tarsus more than twice the length of the middle toe; toes moderate, scutellated, submargined; outer connected at base by a rudimental membrane; inner free; hind toe shorter than a phalanx of the middle one, articulated high on the tarsus, elevated from the ground : nails short, tile-shaped-falculate, obtuse ; middle nail with its cutting edge entire; hind one longest : sole reticulated. WINGS moderate; first and fifth primaries subequal; second, third and fourth, longest; secondaries broader and wider than the primaries; tertials arched, or much elongated.

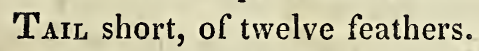

Female hardly differing from the male. Young very different from the adult. Moult annually.

Habits terrestrial. Live in fields, marshes, and salt meadows, which they leave at night to rest on adjacent trees. Food chiefly vegetable, pick up the seeds in ploughed and newly planted grounds; feed also on insects, worms, small reptiles, spawn and small fishes, which they seek in marshy grounds. Build in bushes, in Europe also on the roofs of houses; in marshes on clods and tufts, nest raised to the height of their body with grasses and reeds, lining the tops

VoL. II. 
with soft substances: lay but two eggs, which each sex cover alternately standing, the other at the same time watching; taking great care of their young. Migrate in flocks: notwithstanding their size, undertake periodically more wonderful and hazardous journeys than any other bird: ascending out of sight, moving in an isosceles triangle, especially at night, and performing evolutions suited to the state of the wind, or attacks of rapacious birds. The shrill voice of the leader, re-echoed by the whole flock, indicates their unseen passage. Flight high and silent in fine, low and noisy in stormy weather. Take wing with difficulty. Vigilant: a sentinel watching whilst the whole troop sleeps standing upon one leg, with the head under the wing, and giving alarm at the slightest approach of danger. Venerated, even in some civilized countries.

Inhabit both continents. Analogous, perhaps even somewhat allied to the Gallinæ: closely related to the genus Psophia, by the subgenus Anthropoides, and might, perhaps, be placed in the family Alectorides, thus rendering the character of both families (Alectorides and Herodii) more precise.

224. Grus americana, Temm. White; primaries black, with black shafts; whole crown and cheeks bald.

Young tawny.

Hooping Crane, Ardea americana, Wils. Am. Orn. vii.p. 20. pl.64. fig. 3. adult male.

Inhabits throughout North America and the West Indies; probably also the north of Asia.

225. Grus canadrasrs, Temm. Cinereous; wings varied with testaceous ; primaries brown, with white shafts; anterior portion of the head bald.

Brown Crane, Grus canadensis, Nob. Am. Orn. iii. adult male. Grus fusca, Vieill. Ardea canadensis, $L$. 
Inhabits throughout North America: rarely seen in the middle states.

\section{ARDEA.}

\section{Ardea, L. Gm. Lath. Ill. Cuv. Temm. Vieill. Ranz.}

Ardea, Herodias, Botaurus, Nycticorax, Ardeula, Boié.

Bill long, cleft beneath the eyes, straight, compressedcultrate, acuminate, acute; mandibles subequal, generally serrated in a slight degree near the extremity ; the upper slightly furrowed on each side at base, notched; ridge rounded, somewhat distinct at base, curved gradually at the point: nostrils placed in the furrow, basal, linear, longitudinal, covered behind by a membrane: tongue moderate, membranous, oblong, plain, acute: lora and orbits naked. Body much compressed. FEET long, slender; tarsus but little longer than the middle toe, generally clypeate, superior scales scutelliform, rarely scutellate; toes scutellated, elongated, slender, slightly margined, flattened beneath ; outer connected at base by a membrane; inner nearly free; hind toe articulated internally on a level with the rest, at least half as long as the middle one, resting on the ground, connected at base with the inner : nails long, slender, acute; middle one serrated internally; hind nail largest, much curved, very acute. Wings moderate, obtuse, tuberculated ; first primary subequal to the second and third, which are longest. TAIL short, rounded, of ten or twelve feathers.

Female similar to the male. Young different from the adult, obtaining their full plumage only after the third year. Moult annually. Varying greatly in size in the different species. Adult more ornamented by long slender feathers, lost in moulting, and not renewed for some time. Down silky.

Dull: sitting on trees near the water, or inhabiting morasses. Feed exclusively on animals, especially fishes and reptiles. Build socially in high trees; eggs about four. 
Fly gracefully with the neck bent backwards, and the head resting against the back.

Inhabit throughout the world.

SUBGENUS I. ARDEA.

Hérons proprement dits, Buff. Vieill. Temm. Hérons vrais, Aigrettes, Cuv. Ardea, Stephens.

Bill much longer than the head, at base as broad or broader than high, quite straight. Neck very long, slender, beneath with slender, elongated, pendent plumes : body thinflanked. Legs very long; naked space above the tarsus extensive.

Diurnal. Feed principally on fishes. The largest of the genus.

226. Ardea nerodias, L. Crested; bluish-ash; thighs ferruginous; middle toe much shorter than the tarsus.

Adult, crown black and white, with two long tapering black feathers; back with long, narrow, white, tapering plumes.

Young, crown dark slate; no long feathers on the back.

Great Heron, Ardea herodias, Wils. Am. Orn. viii. p. 28. pl. 65. fig. 2. adult.

Inhabits common, and resident in the union: rare, and migratory in the North-eastern states.

227. Ardea alba, L. Slightly crested; snowy white; bill yellow; legs black, very long, slender, nalsed for four inches above the tarsus.

Adult, back with long flowing plumes stiff and falling, reaching beyond the tail.

Young and moulting destitute of the dorsal train.

Great White Heron, Ardea egretta, Wils. Am. Orn. vii. p. 106. pl. 61. fig. 1 .

Inhabits the northern hemisphere.

228. Ardea Pealir, Nob. Crested; snowy white; bill fleshcolor, the point and legs black ; toes beneath yellow ; tarsus more than five inches long. 
Adult, crest and neck-fringe large, of compact pointed feathers ; back with long, straight, filiform plumes, reaching beyond the tail.

Young destitute of these ornaments.

Peale's Egret Heron, Ardea pealii, Nob. Am. Orn. adult.

Inhabits Florida, and probably the analogous climates of America. Closely allied to the following, and perhaps still more so to the European Ardea garzetta! Intermediate between those two so closely related species! (21.)

229. Ardea candidissima, Gm. Crested; snowy white; bill and legs black; toes yellow; tarsus less than four inches long. Adult, crest and neck-fringe large, of loose flowing feathers; back with long, silky, recurved plumes, hardly reaching beyond the tail.

Young but slightly crested, destitute of the dorsal train.

Snowy Heron, Ardea candidissima, Wils. Am. Orn. vii. p. 120. pl. 62. fig. 4. adult.

Inhabits both Americas; said to be found also in. Asia, which is doubtful.

230. Ardea ludoviciana, Wils. nec auct. Crested; bluishslate; back, rump and beneath, white; neck feathers purplish; back with long, capillary, purplish plumes.

Young destitute of the ornamental feathers.

Louisiana Heron, Ardea ludoviciana, Wils. Am. Orn. viii. p. 13. pl. 64: fig. 1. adult.

Inhabits during the fine season, the south and south-western states; probably also all the warmer portion of America.

SUBGENUS II. BOTAURUS.

Bihoreau et Butor, T'emm. Butors, Bihoreaux, Cuv. Hérons-Bihoreaux, Hérons-Butors, Hérons-Crabiers, Vieill. Botaurus, Nycticorax, Stephens.

Bill hardly longer than the head, much compressed, higher than broad; upper mandible somewhat curved. Legs comparatively short; naked space of the tibiæ restricted. Neck 
rather short, thick, densely covered with long, broad, loose, erectile feathers, merely downy above. Body plump.

Chiefly nocturnal. Keep in marshes, sedgy places. Feed principally on reptiles, insects, worms, and spawn; seldom on fishes. When excited erect their neck feathers.

\section{$\dagger$ Adult with long, narrow, tapering, occipital fcathers.}

231. Ardea vioracea, L. Crested; ash, beneath paler; upper parts streaked with black, with long, loosely-webbed tapering feathers; crown, and spot on each cheek white; two occipital feathers.

Yellow-crowned Heron, Ardea violacea, Wils. Am. Orn viii. p. 26. pl. 65. fig. 1. adult.

Inhabits common in the southern and south-western states, and the West Indies; extending its migrations occasionally to the middle ones.

232. Ardea rycticorax, L. Whitish; crown and back greenish-black; rump, wings and tail, pale ash; three whitish ocripital feathers.

Young, brown streaked with reddish-white; beneath white, streaked with dusky; wing and tail feathers plain dusky, the former with a spot of white at tip : no occipital feathers.

Night Heron, or Qun bird, Ardea nycticorax, Wils. Ain. Orn. vii. p. 111. pl. 51. fig. 2. adult. fig. 3. young.

luhabits both continents: common in Pennsylvania and New-Jersey : leaves the northern and middle states during winter.

233. Ardea cervutea, L. Crested; bluish-slate; feathers of the back and breast, slender and elongated; head and neck purplish-brown ; three occipital feathers.

Young not crested, head and neck of the same color with the body.

Blue Crane, or Heron, Ardea crerulea, Wils. Am. Orn. vii. p. 11\%.pl.62. fig. 3. adult. 
Inhabits common in the south and south-western states: wintering in tropical America : migrates in spring throughout the union; rare in the middle, and especially the nurthern states.

\section{t† $\mathcal{N o}$ long occipital feathers.}

224. Arnea mror, Wils. Yellowish-ferruginous, mottled and sprinkled with deep brown; throat white, streaked with brownish; crown, a wide patch each side of the neck, and quill feathers, plain black.

Young, colors less decided.

American Bittern, Aidea minor, Wils. Am. Orn. vii. p. 35. pl. 65. fig. s. adult.

Inhabits throughout North America, leaving cold regions during winter. Closely allied to Ardea stellaris of Europe.

235. Ardea virescens, L. Crested; glossy green; neck and breast dark vinaceous; a line from the chin down the throat, white streaked with blackish.

Adult, back with long tapering pointed feathers.

Young much less brilliant, destitute of the dorsal train.

Green Heron, Ardea virescens, Wils. Am. Orn. vii. p. 97. pl. $61 \cdot f i g \cdot 1$.

Inhabits throughout North America during the fine season: common: some wintering in the southern states. Found also in the Island of Java!

SUBGENUE III. ARDEOLA.

Bill longer than the head, higher than broad at base; upper mandible nearly straight. Neck elongated, rather slender, thickly covered with long, broad, loose, erectile feathers, merely downy alone : body slender, much compressed. Legs comparatively short: tibiæ wholly feathered: membrane uniting the toes merely rudimental.

Female somewhat differing from the male. Young differing from both. Smallest of the genus. 
Chiefly nocturnal. Live and build in marshy grounds, hiding closely amongst the reeds, and running a great way in them rather than take flight. Feed on small fishes, reptiles, spawn, but especially aquatic insects.

236. Arden exilis, Gm. Chesnut, beneath whitish; neck above rufous; sides and wing coverts, cream; crown, primaries, tail, and tuft each side of the breast, black. Length less than twelve inches.

Least Bittern, Ardea exilis, Wils. viii. p.3\%. pl. 65. fig. 4 .

Inhabits the United States and West Indies: rather rare, and found in summer only, in the northern and middle states. The smallest of the genus: closely related to A. minuta of Europe, from which it is hardly distinguished but by its inferior size.

\section{ARAMUS.}

Scolopax, L. Numenius, Briss. Scolopax, Ardea, Gm. Ardea, Numenius, Lath. Rallus. Ill? Nob. Jour. Acad. Phil. Grus! Cuv. Aramus, Vieill. Temm. Ranz.

BiLl much longer than the head, cleft beneath the eyes, compressed, straight, curved and somewhat turgid at tip, entire; upper mandible slightly furrowed; lower turgid towards the middle, angular beneath, acute : nostrils in wide orifices, rather distant from the base, lateral, longitudinal, linear, pervious : tongue short, narrow, acute. Head wholly feathered; lora naked. FEeт elongated; naked space above the tarsus extensive; toes entirely divided; fore toes elongated, slender, smooth beneath; hind toe articulated posteriorly with the tarsus, half the length of the inner, bearing on the ground with several joints : nails long, slender, compressed, curved, acute, middle one dilated and entire on the inner edge, the posterior longest and stoutest. Wings moderate; first primary rather short, falciform; third longest. TaIL short, rounded, of twelve feathers. 
Female similar to the male. Young but little distinguished from the parents. Moult annually.

Solitary: quiet : shy. Live in arid, desert plains, carefully concealed, and starting rapidly to a great elevation, as soon as aware of being discovered. Alight on trees: walk with great agility, moving the tail when frightened. Feed principaliy on frogs and insects. Build in the grass. Voice loud, shrill.

Peculiar to the warmer parts of America. Composed of but one well ascertained species. Almost intermediate between Ardea and Numenius : closely related to Rallus, (Family Macrodactyli) with which it has been classed by Illiger and myself.

237. Aramus scolopaceus, Vieill. Brown, glossed with green; feathers longitudinally white in the middle; rump, quills, and tail feathers, immaculate.

Scolopaceous Courlan, Aramus scolopaceus, Nob. Am. Orn. iii.

Inhabits Florida, and other warm parts of America : visits occasionally the shores of the middle states. Common in the island of Cuba.

\section{FAMILY XIX. FALCATI.}

Fulcati, Ill. Falcirostres, Vieill. Ranz.

Cultrirostres, Longirostres, Cuv. Latr. Ardeida, Vigors. BiLl very long, stout at base, subulate, falcate, cylindrical at tip; edges much bent in, sharp. Face naked; throat dilatable. Neck elongated. Fevr elongated, 4-toed; uaked space of the tibia extensive ; tarsus reticulated; toes elongated, bordered with a narrow membratre, connecting the fore toes at base; hind toe articulated with the tarsus low down, half as long as the middle one, bearing almost its whole length on the ground. Wings moderate, obtuse, tuberculated. TAIL short, of twelve feathers.

VuL. II. 
Female much smaller, but similar in color to the male. Young differing greatly from the adult until the third year. Moult annually.

Dull, stupid, fearless, easily approached and shot. Frequent inundated places, the shores of lakes and rivers Feed on small fishes, reptiles, mollusca, and iusects: when satiated, retire to the highest trees, where they stand erect, resting their heavy bill on the breast. Monogamous : build on high trees; lay two or three eggs: female only incubating, but is fed by the male, and both feed their young, which leave the nest only when able to flutter. Walk slowly, often sinhing deeply in the mud, while watching for their prey. Flight heavy, but high and protracted.

Internediate between the two families Limicola and Herodii, but much more closely related to the latter: connecting them admirably.

\section{TANTALUS.}

Tantalus, L. Gm. Lath. Ill. Cuv. Vieill. Temm.

Numenius, Briss.

Bill stout, as wide as the face at base, compressed, attenuated, curved only towards the point; upper mandible not furrowed, trigonal at base, then cylindrical, notched; edges approaching each other so closely as to form a narrow channel; lower mandible not channelled: nostrils basal, approximated, longitudinal, elliptic, open, pervious : tongue very short, deep in the throat. Head naked, verrucose, cheeks with scattered feathers. Tarsus twice as long as the middle toe: nails short, somewhat fiattened, rather obtuse. First and second primaries subequal and longest.

Composed of but four species, one in each division of the glube except Europe.

238. Tantalus loculator, L. White, face and head bluish; quills and tail glossy black. 
Young, blackish; head and neck yellowish-white; belly cinereous.

Wood Ibis, Tantalus loculator, Wils. Am. Orn. viii. p. 39. pl. 66 fig. 1. adult.

Inhabits America from Carolina to Brazil: in the United States during summer only.

49. IBIS.

Tantalus, L. Gm. Lath. Numenius, Briss. Falcinellus, Bechst. Meyer. Ibis, Lacep. Ill. Cuv. Vieill. Temm.

BILL slender, thicker at base, tetragonal-cylindrical, arcuated, depressed, obtuse at tip ; upper mandible deeply furrowed its whole length, entire; lower deeply channelled beneath : nostrils in the firrow, basal, lateral, longitudinal, linear, half closed by a membrane: tongue very short, deep in the throat, triangular, thick, smooth, cartilaginous, fimbriated at base. Face and throat naked. Tarsus longer than the middle toe : nails short, somewhat curved, rather obtuse, middle one often pectinated. First primary hardly shorter than the second and third, which are longest.

Feed exclusively on insects, worms, mollusca, and also vegetable substances. Migrate periodically, and to wonderful distances; the migration of some species being limited only by the boundaries of our globe.

Inhabit all quarters of the world. Venerated by the ancient Egyptians.

239. Iв rs rubra, Vieill. Scarlet, richer and brighter according to age; outer quill-feathers blue-black at tip; face reddish.

Young cinereous, back and wings blackish; rump and beneath white.

Scarlet Ibis, Tantalus ruber, Wils. Am. Orn. viii. p. 41. pl. 66. fig. 2. adult. Tantalus fuscus, L. young. (22)

Inhabits the warmer parts of America: during summer only, the southern extremity of the union: rare. 
240. Ibrs alba, Vieill. White, old bird tinged with rose color ; outer quill-feathers blue-black at tip : face reddish.

White Ibis, Tantalus albus, Wils. Am. Orn. viii. p. 43. pl. 66. fig. 3 .

Inhabits as the preceding: common in Florida on the sea shore during summer.

241. Ibis falcinellus, Vieill. Purplish-chesnut; top of the head, middle of the back, wings and tail, metallic green; face blackish.

Young, head and neck feathers streaked with blackish, and margined with whitish; back and scapulars, brownish-cinereous; beneath blacki-h-cinereous; wings and tail duller.

G'lossy lbis, Ibis falcinellus, Nob. Am. Orn. iii. adult. Tanialus mexicanus, Ord, J. Ac. Phil.

Inhabits warm and temperaie shores throughout the globe: a rare visitant of the United States.

\section{FAMILY XX. LIMICOLÆ.}

Limicole, Tittorales, Ill. Longiristres, Cav. Latr. Helionomi, Figialites, Vitill. Limicole, Ta:hidrome, Ranz. Scolopacido, Charadriade, Vigors.

BiLu generally long, slender, feeble, soft, cylindrical, mostly obtise at the point. Face feathered. Neck moderate. FEex moderate or elongated, tender; naked space of the tibia more or less extensive; tarsus reticulated; hind toe slender, short, articulated high on the tarsus, hardly touching the ground at tip, sometimes wanting. Wings elongated, falciform, acute, tuberculated. TAIL rather short.

Female larger, similar to the male in color. Young differing more or less from the adult. Moult twice in the year.

Live in marshes, muddy places, and around water : never alighting on trees. Run swiftly. Feed on insects, worms, 
mollusca, and other marine animals, which they seek in the mud; feeling and taking their prey withont seeing it, by means of their sensible bill.* Munogamous; breed on the ground in marshy grasses, or in the sand; lay generally four pyriform eggs; both sexes incubating, and attending the young: young leave the nest, run about, and pick up their food as soon as hatched. Flesh esculent.

\section{NUMENIUS.}

Numenius, Briss. Lath. Cuv. Ill. Vieill. Temm. Ranz. Scolopax, L. Gm. Tantalus, Lacep.

BILL very long, slender, alinost cylindrical, slightly compressed, arcuated, entire; upper mandible longer, furrowed for three fourths of its length, dilated, and rounded towards tip ; nostrils in the furrow, basal, lateral, longitudinal, oblong : tongue very short, acute. FEET rather elongated, slender, 4-toed; naked space of the tibia moderate; tarsus half longer than the middle toe; toes short, stout, bordered, somewhat rough beneath; fore toes connected at base by a short membrane to the first articulation; hind toe a little longer than a phalans of the middle one, bearing on the ground at tip : nails compressed, curved, acute, the cutting edge of the middle one entire. First primary longest. TaIL somewhat rounded, of twelve feathers.

Female similar to the male both in size and color. Young differing but little from the adult, but well distinguished by their much shorter and straighter bill. Moult annually, late in the season. Colors dull, a mixture of grayish-brown, rusty, white and blackish, hardly varying in the differen species.

* In these birds the bill is wholly or partially covered with a nervous and sensitive skin. 
Extremely shy, wary and cunning. Solitary, except when migrating, then uniting in large flocks. Live in the neighbourhood of salt water and marshes, during summer advancing inland. Feed on worms, insects, small fishes and mollusca, which they seek in the sand or in the mud Nextle on tufts in prairies and marshes. Flight high, rapid, and protracted. Voice loud, whistling.

Spread all over the globe : three species in Europe: three in North America.

242. Numenius rongroostris, Wils. Crown blackish, with whitish streaks, no medial line; rump uniform with the rest; long axillary feathers rusty; bill very long, much arcuated.

Long-billed Curlew, Numenius longirostris, Wils. viii. p. 23. pl. 64 . fig. 4 .

Inhabits throughout North America: common in spring and autumn in the middle states.

243. Numentus hudsonicus, Lath. Crown deep brown, with a whitish medial line; rump uniform with the rest; long axillary feathers banded with black and rusty; bill short, much arcuated.

Esquimaux Curlew, Scolopax borealis, Wils. vii. p. 22. $p l .66 \cdot f_{5} \cdot 1$.

Inhabits throughout North America: breeding to the north, wintering to the south: common on their double passage in the middle states.

244. Numentus boreatis, Lath. nec Ord. Crown blackish, streaked with whitish, no medial line; rump uniform with the rest; long axillary feathers banded with black and rusty; bill very short, but little arcuated.

Esquimaux Curlew, Numenius borealis, Nob. Am. Orn. iii. Numenius brevirostris, Temm. pl. col. 381: (24)

Inhabits throughout North and South America : rare in the United States, found at Hudson's Bay, in the western territory, Brazil, Paraguay, \&c. 


\section{TRINGA.}

Tringa, Charadrius, Scolopax, L. Gm. Tringa, Charadrius, Numenius, Lath. Tringa, Arenaria, Briss. Actitis, Calidris, Ill.* Calidris, Priilua, Machetes, Arenaria, Cuv. Tringa, Arenaria, Vieill. Tringa, Calidris, Temm. Ranz.

Bill moderate, slender, sub-cylindrical, straight, or slightly curved, soft and flexible its whole length, compressed at base, point smooth, depressed, somewhat dilated, obtuse: both mandibles furrowed each side their whole length; lower a little shorter: nostrils in the furrows, basal, linear, pervious, coveréd by a membrane: tongue moderate, slender, subfiliform, canaliculated above, entire, acute. FEeT 3 or 4-toed; tarsus slender; fore toes rather elongated, slender, generally divided; hind toe exiremely short, slender, much elevated, hardly touching the ground at tip, or wanting: nails curved, acute. WINGs moderate; first primary longest. TAIL rather short, of twelve feathers.

Female similar in color to the male, somewhat larger. Young differ from the adult. Moult twice a year, changing greatly the color of their plumage. Colors a mixture of white and cinereous, changing in summer to rufous and black.

Live in flocks, often composed of different species, on sandy beaches, muddy shores, preferring salt water. Migrate according to season along shores and rivers. Feed on insects, mollusca, and other small animals, which they seek in soft ground by inserting their flexible bill. Breed sucially among the grass near water.

* Illiger, however, does not quote under his genus Actitis a single typical Tringa; he probably never examined one, as they do not possess the character he assigns to the group "pedes colligati." 
Spread all over the world, even some of the species. Wantonly multiplied by superficial observers; most difficult to distinguish correctly by brief descriptions.

SUBGENUS I. :HEMIPALAMA.

Hemipalama, Nob. Cbs. Nom. Wils. Orn.

Feet 4-toed; anterior connected at base by a membrane.

Prculiar to America. Comects adnirably the two allied genera Numenius and Tringa. Well marked, but perhaps artificial.

245 Tringa mimantopus, Nob. Bill much longer than the head, sub-arrhed; tarsus longer than the bill; rump white, banded with black; middle tail feathers longest.

Long-legged Sandpiper, Tringa himantopus, Nob. Am. Orn. iii.

Inhabits the middle states in summer and atitumn.

Anomalous: closely related to. Numenius, and as to natural affinity, still more so to Totanus! Ought not to be separated from T. subarquata, Termm. by the straight-billed T. semipalmata, Wils. with which it claims no alliance, except on account of its semipalmated feet.

246. Tringd semipalmata, Wils. Bill shorter than the head, straight ; feet moderate ; rump blackish ; middle tail feathers longest.

Semipalmated Sandpiper, Tringa semipalmata, Wils. vii. p. 131. pl. 63. fig. 4.

Inhabits common throughout the United States. Except by its feet, closely related to T. pusilla, minuta, \&c.

\section{SUBGENUS II. TRINGA.}

Calidris, Pelidna, Cuv.

Feet 4-toed; anterior cleft to the base.

Spread all over the world. Connected much more with the preceding by the European subgenus Machetes, Cuv. in 
Cuv. in which the outer toe is connected by a membrane as in the typical Totani.

247 Tringa subarquata, Temm. Bill much longer than the head, subarched; rump white; middle tail feathers longest, lateral white internally; tarsus shorter than the bill, one inch and a quarter long.

Summer plumage varied with black and rufous, beneath rufous: winter, cinereous, beneath white.

Cape Curlew, Numenus africanus, Lath. Meyer and Wolf, Ois. d'Allem. livr. xix. pl. 4. fig. 1. adult in full dress. fig. 2. young.

Inhabits throughout the world; extremely rare, and merely a transient visitor in the United States.

248. Tringa alpina, L. Bill longer than the head, slightly curved at the point, entirely black ; rump blackish ; middle tail feathers longest; tarsus little more than one inch long.

Summer plumage varied with black and rufous, beneath black and white : winter, ashy brown, beneath white.

Red-backed Sandpiper, Tringa alpinn, Wils. Am. Orn. vii. p. 25. pl. 56. fig. 2. summer dress; and the Purre, Tringa cinclus, Wils. Am Orn. vii. p. 39. pl. 57. fig. 3. winter dress.

Inhabits both continents: very common throughout the United S Sutes and Europe.

249. Tringa schinzin, Brehm. Bill hardly longer than the head, hardly curved, entirely black; rump blackish; middle tail feathers longest; tarsus three quarters of an inch long.

Summer plumage varied with blackish and dull rufous; beneath black and white : winter, ashy brown, beneath white. Schinz's Sandpiper, Tringa Schinzii, Nob. Am. Orn 3. Pelidna cinclus, var. Say in Long's expedition.

Inhabits both continents; found from beyond the MissisVoI!. II. 40 
sippi to the Atlantic shores; rather common in the autumn on the coast of New-Jersey. Exceedingly allied to the preceding; hardly distinguished but by its inferior size, and shorter bill and tarsi.

250. Thinga pectoralis, Nob. Bill shorter than the head, compressed and reddish-yellow at base; rump blark; middle tail feathers longest ; feet greenish-yellow, tarsus one inch long.

Summer plamage varied with black and rufous, beneath white; breast cinereous, strongly lineated with blackish. Winter, cinereous-brown, beneath white.

Pectoral Sandpiper, Tringa pect,ralis, Nob. Am. Orn. iii. Pelidna pectoralis, Say in Long's. erp.

Inhabits thronghout the United States and West Indies: common beyond the Mississippi; often met with on the coasts of New-Jersey in the latter end of summer.

951. Tringa platyranca, Temm. Bill longer than the head, slightly curved at the point, much depressed and reddish at base ; rump black; middle tail feathers longest ; feet greenish-ash; tarsus less than one inch long.

Summer plumage varied with blark and rufous; bencath pure white: winter, cinereous, beneath white.

Numenius pygmaus, Lath. nec Bechst. Naum Vog.t. 10. fig. 22. adult in summer plumave.

Inhabits both contiucnts: extremely rare in the United States.

252. Tringa maritima, Brunn. Bill longer than the head, hardly curved at the point, compressed and reddish at base; rump black; middle tail feather's longest; feet yellow ; naked space above the tarsus very small.

Summer dress purplish-black varied with white and rufous, beneath whitish with blackish spots: winter, blackish, beneath whitish streaked with dusky. 
Purple Sandpiper, Tringa maritima, Nob. Am. Orn. 3.

Inhabits both continents on rocky shores only, hardly ever seen on the eastern coasts of the union; common at Hudson's Bay, in England, \&u. found in Holland only where artificial moles have been formed, making its appearance as they are built.

253. Tringa temurnckir. Leisler. Bill shorter than the head, nearly straight; rump blackish; tail graduated, the outer feathers pure white.

Suminer plumage black, varied with rufous, beneath white: winter, cinereous-brown, beneath white.

Tringa pusilla, Bechst. nec auct. Temm. Pl. Col. 41. fig 1.

Inhabits the Arctic circle, whence it migrates perindically to temperate climates : exceedingly rare in the United States.

254. Tringa minuta, Leisl. Bill shorter than the head, straight; rump blackish; middle and outer tail fenthers longest, lateral, dark cinereous, edgred with white; tarsus longer than the bill, ten lines long.

Summer plumage blackish varied with rufous, beneath white: winter, cinereous, beneall white.

Tringa minuta, Temm. Naum. Vog. t. 21. fig. 30.

Inhabits throughout the world: rare in the United States: common in Switzerland, Italy.

255. Tringa pusilla, Wils. Bill shorter than the head, straight ; rump blackish; middle tail feathers longest, lateral equal, dark cinereous, edged with white; tarsus equal to the bill eight lines long.

Summer plumage blarkish varied with rufous, beneath white: winter, cinereous, beneath white.

Litule Sandpiper, Tringa pusilla, Wils. Am. Orn. v. p. 32. pl. 37. fig. 4 .

Inhabits in great numbers the shores of North and South America : not found in Europe. Hardly differing from the preceding, but by its shorter tarsi. 
256. Tring a istandica, L. Bill hardly longer than the head, straight; rump white, varied with black; tail perfectly even.

Summer plumage black varied with rusty, beneath rusty: winter, light ash, beneath white.

Young, dark ash, varied with black and white, beneath white.

Red-breasted Sandpiper, Tringa rufa, Wils. Am. On. vii. p. 43. pl. 57. fig. 5. summer dress; and ash-culored Sandpuper, Tringa cinerea, Wils. Am. Orn. vii. p. 36. pl. 57. fig. 2. winter dress.

Inhabits both continents: common during spring and autumn in the middle states.

SUBGENUS III. CALIDRIS.

Tringa, Charadrius, Gm. Charadrius, Lath. Arenaria, Briss. Cuv. Vieill. Caliılris, 1ll. T'emm. Ranz.

Feet 3-toed; toes cleft from the base; no rudiment of hind toe.

Keeping almost exclusively on sandy beaches; closely following the flux and reflux of the surf, to pick up the small animals left on the sand.

Cosmopolite. Formed of but a single species, which cannot be separated from the Tringa in a natural arrangement, though authors, taking no other character's in consideration, but the want of hind toe, place it artificially even in a distinct Family or Order !

257. Tringa arenaria, L. Bill shorter than the head, straight; rump ash; middle tail feathers longest.

Summer plumage varied with black, white and rufous, beneath white: winter, light ash, sicies of the head, and all beneath white.

Ruddy Plover, Charadrins rubidus, Wils. Am. Orn. vii. p. 129. pl. 63. fig.3. summer dress. Sanderling Plover, Chara- 
drius calidris, Wils. Am. Orn. vii. p. 68.pl. 59. fig. 4. winter dress.

Inhabits all over the globe : migrating periodically along the coasts of the middle states.

\section{HIMANTOPUS.}

Himantopus, Briss. Ill. Cuv. Temm. Vieill. Ranz. Charadrius, L. Gm. Lath. Macrotarsus, Lacepede, Recurvirostra, Wilson.

BıLL long, very slender, smonth, subulate, cylindrical, somewhat recurved from the middle, rather depressed at base, compressed and acute at the point, both mandibles furrowed on each side half their length: nostrils in the furrows, basal, linear, pervious: tongue short, slender, acuıninate. Head small; eyes very small: neck long. FeEt 3 toed; tibiæ disproportionately long, thin, flexible, almost entirely naked; tarsus thrice as long as the middle toe, very slender and flexible, somewhat compressed; toes rather short, narrow, flattened beneath, edged by a narrow membrane; middle toe longest, connected to the outer by a broad membrane, as far as the first joint, and to the inner by a very small one : nails very small, hardly compressed, rounded above, curved, and rather acute at tip. Wings very long, extremely acute; quills stiff; first primary much the longest. TAIL short, eve'n, of twelve feathers.

$F_{L M A L E}$ hardly differing from the male. Young somewhat different from the adult. Moult iwice in the year.

Live in small florks, near waters, preferring salt marshes and sea-pools. Feed on insects, mollusca, \&c. which they catch both in the air and mud. Breed socially, rassing their nest as it becomes advisable; lay four or six eggs, which they hatch standing. Fly with great rapidity and steadiness, their stiffly protruded legs making up for the deficiency of their tail as a rudder. Walk with difficulty on hard ground, bending their body, on account of their weak 
legs; at ease only on sinking soil, for which their feet are adınirably calculated : wade deeply in the mud and water, swimming orcasionally when losing their depth.

Spread all over the globe. Formed of but two well ascertained species, one of which is reckoned as cosmopolite, though we cannot trace it in America. Ought not to separate Tringa from Totanus : somewhat anomalous in their most natural family : forms, in our system, a small solitary collateral branch, to which might be joined the geuus Recurvirostra.

258. Himantopus nigricolirs, Vieill. White, neck above, scapulars and wings black.*

Long-legged Avocet, Recurvirostra himantopus, Wils. vii. p. 48. pl. 55. fig. 1 .

Inhabits North and South America : not rare during summer in the northern and middle states:

\section{TOTANUS.}

Tringa, Scolopax, L. Gm. Lath. Wils. Tringa, Briss. Chevaliers, Buffon. Actitis, Ill. Tutanus, Bechst. Cuv. Term. Vieill. Ranz.

BiLL moderate, slender, sub-cylindrical, straight, or a little recurved, much compressed its whole length, flexible at base, narrow, hard, smooth, acute, and a little curved at the point ; both mandibles furrowed each side to the middle; lower shorter, somewhat recurved at tip: nostrils in the furrows, basal, lateral, linear, pervious: tongue moderate, filiform, acute. Fent 4-toed; tarsus long, slender; toes slender, smooth beneath; outer conuected at base by a membrane; hind toe short, slender, much elevated, touching the ground

* Himantopus melanopterus, Meyer. (albicollis, Vieill.) White, scapular's and wings black. 
at tip : nails compressed, curved, acute. WINGs moderate; first primary longest. $\mathrm{T}_{\mathrm{A} I \mathrm{~L}}$ generally short, of twelve feathers.

Female similar to the male, somewhat larger. Young differ but little from the adult in winter plumage. Muult twice in the year, changing somewhat.

Live in flocks, some species solitary, in damp meadows, near water, preferring river shores and fresh water marshes; wade deeply. Migrate according to season. Feed on insects, mollusca, which they seek on hard ground, among gravel, or in hard bottomed rivulets, by means of their solid and less sensible bill. Breed socially among the grass near water.

Spread all over the globe, many of the species themselves. Resembling each other closely, very difficult to distinguish without a thorough acquaintance. Closely allied to the genus Scolopax, by its subgenus Macroramphus, to Limosa by our subgenus Glottis, and especially to Tringa by Machetes: well distinguished, however, by the union of the two characters of the feet and bill.

SUBGENUS I. CATOPTROPHORUS.

Part of Chevaliers proprement dits, Temm. Part of Glottis, Nilsson.

Bill straight, stout, solid almost its whole length, furrows only at the base, those of the lower mandible obliterated. Fore toes all connected at hase by a membrane.

Female conspicuously larger.

Not only wade, but swim occasionally.

259. Toranus semipalmatus, Temm. Rump white; lower wing coverts, black; quills white, for two thirds of their length from the base.

Surnmer plumage brownish, varied with blackish and whitish, beneath white, spotted with blackish : winter, light ash, beneath white. 
Semipalmated Snipe, Scolopax semipalmata, Wils. Am. Orn. vii. p. 27. pl. 56. fig. 3. summer dress.

Inhabits throughout North America; an accidental visitant on the western European shores: common during summer in the middle states, where it breeds in great numbers.*

\section{SUBGENUS II. TOTANUS.}

Bill straight, slender, hard, furrowed and flexible nearly to the middle. Inver toe cleft.

More allied to Tringa, (especially Machetes,) by their more serusible bill.

260. Totanus melanoleucus, Vieill. Ashy brown, spotted with black and white; rump white; tail white, barred with brown; feet yellow; bill entirely blackish, slightly recurved. Length fourteen and a half inches.

Tell-tale Godwit, or Snipe, Scol pax vocifera, Wils. vii. p. 5\%. fig. 5. summer dress.

Inhabits througbout North America in suitable places: common from April to November in the middle states, where it breeds.

261. Totanus flavipes, Vieill. Ashy-brown, spotted with black and white; rump white; tail white, barred with brown; feet yellow, bill entirely black, straight. Length ten inches.

Yellow shanks Snipe, Scolopax fiavipes, Wils. vii. $p .55$. pl. 58. fig. 4. summer dress.

* Following the mania of the day, we have formed a new subgenus for the reception of this bird, which deserves the distinction quite as well, and better than a great many others. We adopt Glottis, Nilsson, for those with stout but recurved bills, and inner toe cleft. None are found in the United States, and but one in Europe. 
Inhabits throughout North America : very common during summer and autumn in the middle states. Hardly differing from the preceding but by its smaller size : exceedingly like several European Totani, from each and all of which, however, the above phrase distinguishes it.

262. Totanus bartramius, Temm. Rump black; tail very long, tapering, reaching much beyond the wings! Bill very short.

Bartram's Sandpiper, Tringa bartramia, Wils. Am. Orn. vii. p. 63. pl. 59. fig. 2.

Inhabits North and South America : an accidental visitant in northern and western Europe: common during summer, on the plains near the sea coast of New-Jersey and Long Island, and in great numbers on the extensive prairies beyond the Mississippi.

263. Totanus chloropygius, Vieill. Brown-olive, spotted with white ; rump, and middle tail feathers uniform with the rest ; tail white, barred with broad, regular, blackish bands; quills and their shafts entirely black.

Solitary Sandpiper, Tringa solitaria, Wils. Am. Orn. vii. p. 53. pl. 58. fig. 3 .

Inhabits the United States, during summer in the mountains where it breeds; during winter in the plains and shores: not rare, but by no means numerous in autumn in the middle states. Solitary. Allied to T. Glareola of Europe, but totally distinct.

264. Totanus macularius, Temm. Olive-brown, waved with blackish ; rump and tail olive-brown; three outer tail feathers white, barred with black; quills black, with a white spot on the inner web.

Adult, beneath white, with roundish black spots; bill orange beneath.

Young, beneath pure white; wing coverts undulated with rufous lines; bill wholly blackish.

Vor. II. 
Spotted Sandpiper, Tringa macularia, Wils. Am. Orn. vii. p. 60. pl. 59. fig. 1. adult; Totanus macularius, Nob. Am. Orn. iii. young.

Inhabits throughout North America: though an arctic bird, merely an accidental visitant in the north of Europe! very comnon during the fair season in the middle states where it breeds. Solitary.

This beantiful species, together with its close relative T. hypoleucos of Europe, has the bill furrowed, soft, and flexible to the point, hard merely at the tip, and therefore, almost as sensible as that of the Tringæ, to which they form the passage : they might constitute a section or subgenus, under the name of Tringoides.

\section{LIMOSA.}

Scolopax, L. Gm. Lath. Limosa, Briss. Cuv. Leisler. Temm. Ranz. Actitis, Ill. Limicola, Vieill.

Bilc very long, straight, a little recurved from the middle, sub-cylindrical, rather slender, thick at base, very soft and flexible its whole length, at the point smooth, much depressed, dilated, turgid and obtuse; both mandibles deeply furrowed on each side nearly their whole length; lower shorter; the upper ending in an internal knob: nostrils in the furrows, basal, lateral, covered by a membrane, linear, open, pervious: tongue moderate, filiform, acute. Head large; eyes very large, central. Neck moderate, stout: body inclined, compressed. Fest long, slender, 4-toed; naked space of the tibia extensive; fore toes somewhat scabrous beneath; middle one longest, connected to the outer at base by a membrane; inner free, hardly shorter than the outer; hind toe short, slender, touching the ground at tip : nails falculate, the middle one with a projecting ridge, hollowed out beneath on the inner side. Wings long, extremely acute; quills stiff; first primary longest. Tall moderate, of twelve feathers. 
Female larger; colors somewhat duller. Young hardly differing from the adult in winter plumage. Moult twice in the year, changing greatly their plumage, the female later than the male, hence said to differ. Larger than the allied genera, except Numenius.

Timid, melancholy, shy, suspicious, watchful. Migrate according to season. Live in flocks, keeping constantly in moist grounds, morasses near water, preferring salt marshes, rarely found far from the sea; affecting muddy places above all things. Chiefly nocturnal, hiding and keeping quiet during day-time among grasses, reeds, and going out in the morning and evening only. Feeding at twilight and by moonshine on insects, \&c. which they seek in the softest mud: thrust their bill into it continually in search of small animals and vegetables. Sight weak and short, supplied by their exquisitely sensible bill, which being furnished with nerves to the tip, is capable of tasting whatever it seizes. Like the gallinaccous birds, assist digestion by taking sand and small stones into their gizzard for trituration. Breed socially in damp meadows; lay on the ground among grass, bushes. Voice hoarse, shrill, compared to that of a goat. Escaping rapidly among reeds and swampy grounds when perceived.

Spread all over the cold and temperate regions of the globe. Formed of but three well established species, two of which are found in Europe, and two also in the United States. More closely allied to Totanus by its European subgenus Glottis, Nob.

265. Limosa egoceprata, Nob. Bill straightish; rump and tail black; base of the quills and tail feathers white; middle nail long, serrated.

Summer plumage, black varied with rufous; beneath rufous, varied with blackish : winter, ashy-brown, beneath whiteish; tail tipped with white.

Black-tailed Godwit, Limosa agocephala, Nob. Am. Om. 
iii. La Barge commune, Buff. pl. enl. 874. Limosa mela nura, Leisl. Temm. Scolopax limosa, and S. cegocephala. L.

Inhabits both continents : common at Hudson's Bay, and in high northern American latitudes; a transient visiter during spring and autumn in the middle states: extremely common in the Netherlands.

266. Lmosa fedoa, Vieill.* Bill recurved; rump uniform with the rest; tail brownish, banded with black; middle nail short, entire.

Summer plumage, black varied with rufous, beneath rusty: winter, cinereous, beneath whitish.

Great Marbled Godwit, Scolopax fedoa, Wils. Am. Orn. vii。 p. 30. pl. 56. fig. 4. female.

Inhabits throughout North America; a transient visiter in spring and autumn in the middle states : not very common.

\section{SCOLOPAX.}

Scolopax, L. Briss. Gm. Lath. Cuv. Ill. Temm. Ranz. Rusticola, Scolopax, Vieill. Scolopax, Gallinago, Macrow ramphus, Steph.

BrLr long, slender, straight, sub-cylindrical, compressed, soft and flexible its whole length, point depressed, dilated, tumid, obtuse, wrinkled after death $: \nmid$ both mandibles furrowed to the middle; upper terminated by an internal knob; lower shorter, canaliculated, truncated: nostrils in the furrows, basal, marginal, linear, pervious, covered by a membrane: tongue moderate, filiform, acute. Head large, compressed,

* Limosa rufa, Briss. Bill recurved; rump white; tail banded with black, middle nail short, entire.

Summer dress, black varied with rufous, head and beneath rufous, the former streaked with brown: winter, cinereous, beneath pure white.

La Barge rousse, Buff. pl. enl. 900 . summer dress.

Inhabits the north of the old continent: common in northern and western Europe.

+ Owing to the desiccation of their exquisite nervous apparatus. 
somewhat angular, low forward, high behind; eyes very large, placed high and far back. Neck moderate, stout. Body compressed, very fleshy. FEET moderate, slender, 4-toed; naked space on the tibia small: tarsus rather shorter than the middle toe; anterior toes rather long, slender, scabrous beneath; middle toe longest; inner free; hind toe short, slender, touching the ground at tip : nails falculate. Wings moderate; first and second primaries subequal, longest. TaIL short, rounded, of from twelve to sixteen feathers.

Female similar to the male, a little larger. Moult twice a year.

Stupid. Live in swampy woods, forests, or in open marshes and morasses. Feed exclusively on insects and other small animals, which they seek in the mud and slime, and turning over decayed leaves. Breed on the ground; eggs about four. Nocturnal, go about in the morning and evening. When pursued keep close to the ground, and by hiding their head in their feathers, think to avoid their numerous enemies; when close chased, start on the wing with great rapidity. Flesh exquisite.

Spread all over the world. Composed of three subgenera.

SUBGENUS I. MACRORAMPHUS.

Bécassine-Chevalier, Temm. Macroramphus, Leach. Scolopax, Vieill.

Feet elongated; tibiæ partly naked; outer toe connected by a membrane to the middle as far as the first joint; hind nail projecting over the toe, acute. Tail of twelve feathers.

Vary according to age and season.

Gregarious; keep and fly in flocks. Inhabit open marshy grounds in the neighbourhood of the sea; not hiding in the grass. Flight high, and rapid.

Formed of a single species, of which seven or eight nominal have been made. More related in form, colors, changes 
and habits, to the other genera of the family. Connects Scolopax with Totanus and Limosa.

267. ScolopaX GRISEA, Gm. Rump white ; tail banded with black and white; shaft of the first primary white.

Summer dress, black varied with reddish and cinereous; eyebrows and breast reddish : winter, cinereous, beneath white.

Red-breasted Snipe, Scolnpax noveboracensis, Wils. Am. Orn. vii.'p. 48. pl. 53. fig.2. summer dress.

Inhabits throughout North America : very common in the middle states at its double passage : an accidental and very rare visitant in the north of Europe.

SUBGENUS II. SCOLOPAX.

Bécassine, Temm. Scolopax, Vieill. Gallinago, Steph.

Feet moderate; tibia partly naked; all the toes cleft; hind nail projecting over the toe, acute. Tail of from twelve to sixteen feathers. Young similar to the adult: do not change in moulting.

Colors a mixture of black, white, rufous, and cinereous.

Solitary. Live in open marshes, on the borders of rivers, fresh water pools, in damp, and sometimes even dry prairies; always hiding in the grass, not perceived until started. Flight high, very rapid, and irregular.

Spread all over the globe, even some of the few species of which it is formed.

263. Scolopax wrlsonir, Temm. (24.) Tail rounded, of sixteen feathers, all barred with black at tip, the lateral half as broad as the middle ones.

Snipe, Scolopax gallinago, Wils.Am. Orn. vi.p. 18.pl. 47. fig. 2 .

Inhabits North and South America : very common during autumn in the middle states, where a few breed. Resembling excessively S. gallinago, and S. Brehmii of the old continent: perhaps they form but a single species. 
SUBGENUS III. RUSTICOLA.

Bécasse proprement dite. Temm. Rusticola, Vieill. Scolopax, Steph.

Feet short; tibia wholly feathered; toes cleft from the very base; hind nail not projecting beyond the toe, obtuse. Three first primaries very narrow, linear, subequal ; fourth and fifth longest. Tail of twelve feathers.

Female conspicuously larger, with a much longer bill. Young similar to the adult. Do not change in moulting.

Colors a mixture of black, rufous, and cinereous.

Solitary. Live in forests, wooded swamps and thickets, fond of Indian corn fields, seldom seen in open grounds. Carefully watch their young, even carrying them from danger on their back.

Flight low, slow, direct. Cosmopolite. But two species, one in each continent.

269. Scolopax minor, Gm.* Hind head black, with three yellowish bands, beneath plain yellowish-rusty; quills plain dusky.

Woodcock, Scolopax minor, Wils. vi. p. 40.pl. . . fig.2.

Inhabits throughout temperate America, wintering between the tropics : very common during the fair season in the middle states where they breed, and a few appear to winter.

\section{FAMILY XXI. MACRODACTYLI.}

Macrodactyli, Lobipedes, Ill. Macrodactyli, Cuv. Latr. Macrodactyli, Macroniches, Pinnatipedes, Vieill.

Macrodattili, Pinnatipedi, Ranz. Rallida, Vigors.

BiLl short or moderate, hard, thick at base, straight, compressed, entire, curved at the point, sharp on the edges. Head

* Scolopax rusticola, L. Head transversely banded; beneath rusty, undulated with blackish; quills banded with black and rufous.

La Becasse, Buff. pl. enl. 885.

Inhabits throughout the old continent : breeding in arctic regions. 
small : neck well proportioned : body slender, much compres sed. FeEs moderate, rather robust, 4-toed; naked space of the tibia rather small; tarsus not longer than the middle toe, reticulated; toes three before, one behind, very long, slender, divided, edged by a decurrent membrane; hind toe rather long, articulated almost on a level with the others, bearing on the ground good part of its length : nails slender, compressed, acute. Wings rather short, wide, somewhat rounded, concave, tuberculated; third or fourth primary longest. TAIL short, of twelve feathers.

Female smaller, differing but little from the male. Young differing often from the parents. Moult once or twice in the year, without changing their colors.

Solitary. Keep mostly near or in water ; moving nimbly on marshy weeds. Fond of concealment. Feed on small animals, and on seeds and other vegetable substances. Monogamous: lay once or twice in the year: both sexes sit in turn: eggs rounded, from five to sixteen. Young run about under the parental care, and provide for thernselves as soon as hatched. Run swiftly. Fly slowly, at short distances, the feet hanging down. Prefer running to flying. When hard pushed, stop short and squat down, resorting to wing only at extremity. Flight only rapid when elevated. Voice hoarse. Flesh sapid.

56. RALLUS.

Rallus, L. Cuv. Vieill. Rallus, Porphyrio, Briss. Rallus, Parra, Fulica, Gm. Rallus, Gallinula, Lath. Temm. Ranz. Rallus, Crex. 1ll. Rallus, Ortygometra, Zapornia, Leach.

BILL varying in length, thick at base, generally straight, compressed; upper mandible furrowed each side, somewhat vaulted and curved at tip, base extending upwards between the feathers of the front; nostrils in the furrows, medial, oblong or longitudinal, open and pervious beneath, covered at base by a membrane: tongue moderate, narrow, com- 
pressed, entire, acute, fibrous at tip. Forehead feathered. Body very compressed. NAKED space on the tibia small; tarsus subequal to the middle toe, somewhat compressed; toes entirely divided; decurrent membrane very narrow; hind toe equal to a phalanx of the middle one, inserted a little higher than the others : nails short, compressed, curved, acute. First primary shorter than the fifth; second, third and fourth longest. TAIL very short, feathers flaccid, not appearing beyond the coverts.

Female generally similar to the male. Young differing much from the adult. Moult twice in the year.

Timid : shy: solitary. Most of the species live and breed in marshes, among weeds, thickets, preferring the neighbourhood of stagnant waters, where the grass is very high ; not entering much in the water: swim but rarely, and never from choice. Avoid above all, sands and exposed shores. Notwithstanding their apparently limited flight, undertake great periodical journeys. Walk with agility and grace, raising their head, elevating their feet, and jerking their tail. Alight sometimes on low branches, never on trees, unless to escape a close chase. Lives nocturnal: hide closely during day time in the thickest grasses, and seek their food in the morning and evening, or by moonlight.

Inhabit throughout the world. Closely related to Fulica, Gallinula, but especially Porphyrio; distinguished from all by their feathered front.

SUBGENUS I. RALLUS.

Rallus, Briss. Lath. Ill. Temm. Ranz.

Bill longer than the head, slender, straight, subequal throughout, compressed at base, cylindrical and obtuse at the point; upper mandible furrowed beyond the middle; nostrils more basal, linear.

270. Rarlus crepitans, Gm. Black, skirted with brown, beneath rufous; throat white: wing coverts chesnut: first

VoL. II. 
primary edged externally with pale rusty. Length fourteen inches.

Young, greenish-ash, beneath whitish.

Clapper rail, Rallus crepitans, Wils. Am. Orn. vii. p. 112. pl.62. fig.2. adult.

Inhabits all along the Atlantic coasts of the Union : common from spring to autumn in the middle states, where it breeds; a few wintering in the southern.

271. Rallus virginianus, L. Black, skirted with brown, beneath rufous ; throat white ; wing coverts chesnut ; first primary entirely black. Length ten inches.

Female and young much paler.

Virginia Rail, Rallus virginianus, Wils. Am. Orn. vii. p. 109. pl. 62.fig. 2 .

Inhabits throughout North America; extending its migrations far to the north : rare, and during the fair season only, in the middle states, where it breeds; wintering to the south.

SUBGENUS II. CREX.

Crex, Bechst. 1ll. Porphyrio, Briss.

Gallinula, Lath. Temm. Ranz. Crex, Gallinula, Meyer.

Bill shorter than the head, robust, much higher than wide at base, tapering, compressed, and acute at the point ; upper mandible furrowed at base only, a little curved at tip; lower navicular; nostrils exactly medial, oblong.

Apparently well defined, but not so in nature, as the species pass from one form to the other by insensible degrees: may be separated from Rallus, but not united to Gallinula, from which it differs in form and habit, the latter being more closely allied to Fulica, where Linnè placed it.

272. Rar.rus carolinus, L. Olive-brown, skirted with black; back and wings streaked with white lengthwise; beneath slate color; first primary edged externally with pure white.

Male, throat black.

Female and young, throat white. 
Rail, Rallus carolinus, (virginianus) Wils. Am. Orn. bi. p. 24. pl. 43. fig. 2. male.

Inhabits at proper seasons throughout North, and in South America: very common during summer and part of the autumn in the middle states : wintering in tropical America.

273. Rallus noveboracensis, Nob. Black, skirted with rusty, all over with transverse white lines; beneath yellowish-rusty; lower wing coverts pure white.

Female and young duller, less lineated.

Yellow-breasted Rail, Rallus noveboracensis, Nob. $\boldsymbol{A m}$. Orn. iii. pl. 24. Fulica noveboracensis, Gm. Gallinula noveboracensis, Lath. Rallus ruficollis, Vieill. Gal. des Ois. pl. 266. bad fig. Perdix hudsonica? Lath.

Inhabits throughout North America: rare: found in the neighbourhood of New-York, the western states, and on the remotest limits of the North-western territories.

\section{5\%. GALLINULA.}

Gallinula, Briss. Lath. Cuv. Temm. Ranz. Fulica, L. Gm. Crex, Ill. Hydrogallina, Lacepede. Gallinula, Porphyrio, Vieill.

Bilu shorter than the head, rather stout, much higher than wide, tapering, compressed, straight, convex at the point; both mandibles furrowed; upper covering the margins of the lower, inclined at the point, the base spreading into a naked membrane covering the forehead; lower navicular; nostrils in the furrow, medial, lateral, oblong, pervious, half closed by a \&urgid membrane: tongue moderate, compressed, entire. ANTERIor toes extremely long, flattened beneath, bordered by a narrow membrane; hind toe bearing on the ground with several joints : nails compressed, subarched, rather acute. Wings concave, rounded; first primary shorter than the fifth ; second and third longest. TAIL short, hardly appearing from under the coverts. 
Female scarcely differing from the male. Young very different from the adult. Moult annually.

Live near fresh water, preferring rivers and springs, in which they swim easily, striking the water continually with their tail ; diving when frightened, but not after food. Feed on small fishes, mollusca, insects, vegetables. Build in marshes, always in the same spot, attaching their nests to aquatic plants ; nest formed of coarse materials in great abundance; careful parents. Run rapidly: fly badly. Do not undertake other journeys than from mountainous districts to the plain, thus obtaining a change of season. Hide mostly during day time among grass and roots; seen sporting on the water towards evening.

Spread all over the temperate and hot climates of the world, even the same species in both continents, though in restricted and northern latitudes! Formed of but three well ascertained species, two of which North American.

274. Gallinula martinica, Gmel. Lower wing-coverts blue; all the under tail-coverts pure white : no colored circle around the tibia.

Adult, purple, back and tail green, sides of the neck and wings blue.

Young varied with dull purplish and dasky, beneath with black and white.

Purple Gallinule, Gallinula porphyrio, Wils. Am. Orn. ix. p. 67. pl. 73. fig. 2 .

Inhabits during summer only the most southern states where it breeds; wintering in tropical America. Resembling much by its brilliant colors, the species of the connecting genus Porphyrio; hence placed in it by Vieillot.

275. Gallinula chlonopus, Lath. Lower wing-coverts slate color; lateral under tail-coverts only white; a red circle around the tibia.

Adult, dark slate, tinged with olivaceous on the back. 
Young, brownish-olive, beneath whitish.

Common Gallinule, Gallinula chloropus, Nob. Am. Orn. iii. pl. adult.

Inhabits throughout the year in the southern states only: common in Europe, and found with little or no variations in all warm and temperate climates! A most singular fact, which would lead to the belief of the existence of as many species. Corresponds exactly with my European, and especially Java specimens.

\section{FULICA.}

Fulica, L. Briss. Gm. Lath. 1ll. Cuv. Temm.. Vieill. Ranz。 Bilu shorter than the head, stout, nearly straight, conicoconvex, compressed, higher than broad at base, tapering, acute at tip; mandibles equal; upper covering the margins of the lower, furrowed each side at base, subvaulted, the base running far up, and spreading out into a naked membrane covering the forehead, sometimes furnished with crest-like appendages; lower mandible navicular: nostrils in the furrow, medial, lateral, concave, oblong, pervious, half closed by a turgid membrane: tongue compressed, entire. FeEt placed far back, moderate; naked crural space small ; tarsus shorter than the middle toe, compressed, rounded before, somewhat sharp behind; anterior toes very long, slender, nearly divided, edged on both sides by a broad scalloped membrane; hind toe equal to a phalanx of the middle one, bearing on the ground nearly its whole length, edged on the inner side by an entire membrane : nails short, compressed, curved, very acute. WINGS moderate, rounded, concave; first primary equal to the fifth; second and third longest. TAIL short, narrow, of twelve or fourteen feathers.

Female hardly differing from the male. Young but little dissimilar to the adult. Old birds exhibiting striking differences in the form and color of the frontal disk. Monlt twice 
a year, but do not change their colors. Plumage thick and close, impermeable. Colors blackish.

Aquatic. Live in fresh as well as salt water, but always near the shore. Among the best of swimmers and divers; swim on the surface, or beneath, quite as well and better than many of the web-footed tribes, keeping longer under water than most of them. Nocturnal: old birds never seen in day time: young less shy, playful, easily approached, fixing the gunner, and by diving at the flash, avoid the shot; diving also for their food. Feed on small fishes, insects, mollusca, aquatic plants. Copulate in the water: breed in marshes, among the grass; nest large, composed of aquatic weeds; eggs numerous, large; both sexes incubate, and take care of the young; young taking the water as soon as hatched. Walk with difficulty, and hardly ever but from one pond to another, taking wing if the distance is at all considerable. Rise on the water, spreading the wings, fluttering and running along the surface. Seldom seen on the ground, where they are so awkward as to suffer themselves to be caught. Take wing with difficulty, and during day time, only in great emergencies, even in preference burrowing into the mud. Flight when raised, rapid. Flesh black, unpalatable.

Spread all over the world. Species few ; one in Europe; one closely allied in North America; one in Africa, two or three in South America. Nearly related to Gallinula, certainly of this family : artificially, but most unnaturally, united to any other bird.

276. Fulica americana, Gm. Slate color, under tail coverts and exterior lining of the wings pure white; tail of fourteen feathers.

Adult, head and neck deep black; membrane white.*

* As soon as the bird is dead, the membrane becomes tinged with reddish or dark chesnut in the European, as well as the American species. 
Young, head and neck brownish-black, beneath paler, and somewhat mixed with white.

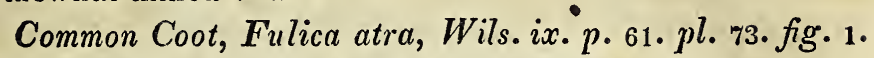

Inhabits throughout North America : wintering and breeding in the south, retiring to the north during summer: not rare in autumn in the middle states.

\section{FAMILY XXII. PINNATIPEDES.}

Order Pinnatipedes, Lath. Temm. Lobipedes, Ill. Longirostres, Cuv. Pinnatipedes, Vieill. Ranz. Pterodactyli, (Pinnidactyli) Latr. Scolopacide, Vigors.

BILL moderate, slender, straight, sub-cylindrical; both mandibles furrowed each side nearly their whole length; upper one somewhat curved at the point; lower hardly shorter, quite straight, point subulate: nostrils in the furrow, basal, lateral, longitudinal, linear, half covered by a męmbrane. HEAD small, wholly feathered, compressed, rounded above; eyes small; neck well proportioned; body roundish. FEET moderate, 4-toed; naked space on the tibia rather extensive; tarsus as long as the middle toe, moderate, robust, somewhat compressed, reticulated; toes moderate, rather slender; three anterior bordered by a festooned or lobed membrane; outer connected at base to the middle one ; hind toe short, bordered only internally with a sinall, entire membrane, articulated rather high and internally, touching the ground at tip : nails short, curved, acute. Wings long, falciform, acute ; first and second primaries subequal, longest. TAIL short, of twelve feathers, under coverts extending to its tip.

Female differing a little from the male, larger; handsomer in full plumage. Young very different from the adult, and varying much according to age. Moult twice in the year, changing their colors wonderfully. Plumage close, thick, abundantly furnished with down, impermeable. Colors 
Colors in summer brownish and reddish, changing in winter to gray and white.

Essentially aquatic. Not shy. Live in small flocks on sea coasts, and rarely fresh-water lakes, venturing far at sea. Feed on aquatic insects and other small animals, which they seek in lakes or the sea. Strictly monogamous : copulate in the water : build on shore, among grass : eggs 4-6: both sexes incubate and attend the young; young leave the nest, run about and swim as soon as hatched. Flight rapid, elegant. Hardly ever seen on dry ground. Smallest of swimmers: swim expertly, resisting the heaviest waves, never diving. Flesh oily, unpalatable.

Inhabit Arctic seas, whence they migrate in the autumn and winter, to the temperate regions of both continents. Formed of but one genus; only three species, all found in North America, though two only in Europe; very much embroiled, and of which several nominal have been formed; each fully deserves to constitute a subgenus. Placed by authors in different families and even orders. In form and habits different from all, and deserving a separate station. Connects the Family Limicolæ, with the Order Anseres.

\section{PHALAROPUS.}

Phalaropus, Briss. Lath. Ill. Temm. Ranz. Tringa, L. Gm. Phalaropus, Lobipes, Cuv. Phalaropus, Crymophilus, Vieill.

\section{SUBGENUS I. PHALAROPUS.}

Phalaropus, Cuv. nec Vieill. Crymophilus, Vieill.

Bill moderate, stout, much depressed throughout, somewhat trigonal at base, point dilated, rounded, curved : nostrils not quite basal, subovate: tongue short, broad, fleshy, obtuse at tip. Tarsi short, robust, but little compressed; anterior toes shortish; middle one connected with the outer to 
the second joint, with the inner to the first ; edging membrane broad, deeply scalloped; hind toe very short, the nail only touching the ground. Wings moderate. Tail rather long, much rounded. General form robust.

Resembling Tringa, especially Hemipalama. Formed of but one species.

27\%. Pratakopus Futicarius, Nob. Blackish varied with rusty, beneath rufous.

Winter dress cinereous, beneath white.

Young, ashy-brown, varied with yellowish-rufous, beneath white.

Red Phalarope, Phalaropus hyperboreus, Wils. Am. Orn. ix. p. 75. pl. 73. fig. 4 .

Inhabits the north of both continents : rare, and accidental, and during winter only, in the United States; extending its migrations to Florida: common in high northern American and Asiatic latitudes, where it breeds.

SUBGENUS II. LOBIPES.

Lobipes, Cuv. Phalaropus, Vieill.nec Cuv.

Bill moderate, slender, smooth, cylindrical throughout, a little stoutish at base, subulate to the tip, point narrow, sharp; upper mandible slightly curved upon the lower at tip, not exactly meeting, as in some Totani: nostrils not quite basal, linear: tongue filiform, acute. Tarsi rather long, moderately compressed; toes somewhat elongated; middle one connected with the inner to the first, and with the outer to the second joint; edging membrane broad, deeply scalloped; hind toe very short, the nail only touching the ground. Wings elongated. Tail rather short. General form slender.

Swim more expertly, taking the water even far at sea. Resembling Totanus, especially its subgenus Catoptrophorus. But one species.

VoL. II. 
273. Phataropus myperbonevs, Lath. Black varied with rufous, beneath white; sides of the neck bright rufous.

Winter plumage, cinereous, beneath white.

Young, brownish varied with pale rufous, beneath white.

Hyperborean Phalarope, Phalaropus hyperboreus, Nob. Am. Orn. iii. Tringa lobata, and lyperborea, $L$.

Inhabits the north of both continents: exceedingly rare and accidental in the United States, very common in the northern British Islands.

SURGEYUS III. HOLOPODIUS.

Phalaropus, Vieill. Lobipes, Nob. Obs. Jardine and Selby Illus. of Orn.

Bill long, very slender, smooth, fexible, cylindrical and of equal breadth throughout, subulate to the tip, point narrow, sharp, slightly curved : nostrils quite basal, linear-elongated: tongue filiform, acute. Tarsi elongated, much compressed; toes elongated; outer connected as far as the first joint only to the middle one; inner almost divided; edging membrane narrow, sub-entire; hind toe long, resting on the ground. Wings elongated. Tail moderate. General form slender.

Resembling greatly the subgenus Totanus.

279. Phataropus wilsonir, Sabine. Bluish-gray, beneath white; a chesnut patch, and a black band each side of the neck.

Summer plumage unknown.

Young, ashy-brown, varied with white and rufous, beneath white; sides of the neck tinged with rufous, no black line.

Gray Phalarope, Phalaropus lobatus, Wils. ix. p. 72. pl. 73. fig. 2. and Wilson's Phalarope, Phalaropus wilsonii, Nob. Am. Orn. iii. adult and young. Lobipes incanus, Illus. of Orn. pl. 16. young (25).

Inhabits the north of America, extending its winter migra. 
tions to the coast of Mexico :* rare and accidental in the United States.

Differs more essentially from the two others, than they do between themselves.

\section{FAMILY XXIII. HYGROBATE.}

Palmipedes pedibus longioribus, Lath. Hygrobata, Ill. Cultrirostres, Longirostres, Phœnicopteres, Cuv. Palmipedes, Latirostres, Vieill. Igrobate, Latirostre, Fanz. Pterodactyli, (Pinnidactyli,) Cultrirostres, Pyxidirostres, Latr. Arderda, Scolopacida, Vigors.

BiLL longer than the head, singularly shaped: nostrils basal, longitudinal, narrow. HeAD small; neck more or less elongated, slender: body somewhat compressed. FEET long, 4-toed; nalsed space of the tibia longer than the middle toe; tarsus much longer than the middle toe, reticulated; fore toes palmated, membrane emarginated; hind toe free. Wings moderate, tuberculated; first or second primary longest. TAIL short, of twelve or sixteen feather's.

Essentially waders. Live on the sea shore. Run rapidly even in the water: swimning occasionally, but never from choice, nor after food. Undertake great periodical journeys. Monogámous: breed on shores or inundated places, some on trees by the sea : eggs few. Voice shrill, acute. Flesh not good.

Spread all over the world. Connects the Order Grallæ with that of Anseres, certainly belonging to the former. Perhaps artificial: formed of three very different genera, each of which may constitute a family, or be distributed among the others; the common character of the palmated feet, being considered as one of analogy simply.

* Erroneously given as African, and South American. 
Recurvirostra, L. Gm. Lath. Ill. Cuv. Temm. Vieill. Ranz。 Avocetta, Briss. Scopoli.

BILL very long, weak, slender, smooth, much depressed throughout, flexible and recurved from the middle, subulate, acuminate, and almost membranaceous at the point, slightly curved at tip; margins internally canaliculated; mandibles subequal, furrowed each side at base : nostrils in the furrow, basal, linear, elongated, open : tongue short, entire. Head small : eyes moderate : neck slender, not much elongated: body slender. Tarsus one third longer than the middle toe, slender, compressed; anterior toes moderate, slender; webs deeply indented; hind toe exceedingly short, articulated high upon the tarsus, entirely raised from the ground : nails short, but little curved, not very acute. Wings long, acute: quills twenty-six; first primary longest. TaIL of twelve feathers.

Female similar to the male, smaller. Young differing but little from the adult. Moult but once a year, in the autumn; acquiring, however, in spring, many additional feathers. Plumage rather thick and close, abundantly furnished with down. Colors white and black, often with reddish tints.

Remarkably shy. Helpless: justly timorous. Noisy. Live by pairs or small parties in inundated marshes, almost always half leg deep in water. Run rapidly in or out of the water, and swim with agility. Feed on small insects and spawn, which they catch by beating the water, their bill permitting them only to seek in liquid mud or water. Breed in small cavities lined with a few weeds, or on the bare sand: eggs 2-4, pyriform: both sexes incubate, folding their long legs to the body. Young run about and provide for themselves as soon as hatched, hiding carefully, and attentively protected by the parents. Flight rapid, long sustained. 
Traced all over the world. Formed of four species, one in each quarter of the globe. In form and especially habits, closely allied to the Family of the Limicolæ, in which it may be placed with propriety, in the small collateral branch of its near relation Himantopus. Also much allied to the Phalaropes! They would form a very natural small family, to which might be united Himantopus, the family of Limicolæ remaining then perfectly natural and uninterrupted.

280. Recurvirostra americana, L. White, tail tinged with cinereous; back and wings black; whole head and neck pale rufous.

American Avocet, Recurvirostra americana, Wils. vii. $p$. 126. pl. 63. fig. 2 .

Inhabits during summer the United States, where it breeds: not very common: winters in tropical America.

\section{PLATALEA.}

Platalea, L. Gm. Lath. Ill. Cuv. Temm. Vieill. Ranz. Platea, Briss.

BicL very long, large, flexible, straight, much flattened throughout, dilated and orbicular at the point, covered by a skin wrinkled, knotted, and scaly at base; both mandibles furnished internally with dense symmetrical striæ, and a channel denticulated on its borders; upper deeply furrowed each side from the base round the end, terminated by a hooked nail : nostrils in the furrow, basal, approximated, oblong, open, margined by a membrane : tongue very short, slender, triangular, acute. Head moderate, more or less naked; bare skin of the throat dilatable; eyes moderate, placed high near the base of the bill ; orbits naked : neck rather long and slender : body rather plump. Tarsus but little longer than the middle toe, robust ; fore toes long, webs very deeply indented; hind toe elongated, articulated nearly on a level with the rest, bearing on the ground nearly its whole length; nails 
short, convex, curved, acute. Wings moderate, ample; first primary a little shorter than the second, second longest. TaIL of twelve feathers.

Female scarcely differing from the male. Young very different from the adult, and changing repeatedly for several years, the bill also developed by degrees. Moult simple, annual. Colors in large masses.

Noisy. Live in small flocks in woody marshes, principally near the mouths of rivers. Alight on trees. Wade slowly deep into the water, but never beyond their depth. Flight easy, slow, elevated. Feed on small fishes, reptiles, spawn, mollusca, and vegetables, probing the mud with their sensible bill : produce a clattering noise by striking their powerless mandibles rapidly together, thus frightening other birds out of their prey. Build generally on trees near the sea side, or on bushes, \&c. Eggs from 2 to 4. Female only incubates, but is fed by the male, who shares the parental duties. Young fed by the parents, remaining in the nest until fullfledged.

Spread throughout warm and temperate climates. Formed of four species, one in Europe, one in America. Allied in form and habits, to the Family Herodii, where, according to nature, it should be placed.

281. Platalea ajaja, L. Whole head bald.

Adult, red. Middle aged, rose color. Young, white Chick, blackish-chesnut.

Roseate Spoonbill, Platalea ajaja, Wils. Am. Orn. vii. p. 123. pl. 63. fig. 1. middle age.

Inhabits during summer only, the most southern states: rare: common throughout tropical America. 
62. PHENICOPTERUS.

Phonicopterus, L. Briss. Gm. Lath. Ill. Cuv. Temm. Vieill. Ranz.

BILl longer than the head, large, higher than wide, light and hollow, furnished at base with a membrane, suddenly bent downward in the middle: upper mandible furrowed each side, convex, high and trigonate at base, beyond the bend very thin and almost plane, narrow, curved, and rather obtuse at tip; lower wider, oval, forming a broad deep channel, at base not so high as the upper, very deep at the bend; margins of both wide, finely toothed, those of the upper densely striated internally; palate carinated: nostrils in the furrow, somewhat distant from the base, approximated, narrow, longitudinal, pervious, furnished above with an extensible membrane: tongue thick, fleshy, covered by recurved, hooked papillæ, glandular at base, cartilaginous and acute at tip. Head small, near the bill naked; eyes large : neck exceedingly long, very slender : body rounded. FEeT very slender; naked space of the tibia twice, tarsus thrice, as long as the middle toe; tarsus hardly compressed, reticulated; anterior toes moderate; webs almost entire; hind toe exceedingly short, articulated high upon the tarsus, touching the ground at tip: nails short, laminar, the middle tile-shaped. Wings moderate, quills forty; first and second primaries subequal, longest. Tar short, of sixteen feathers.

Female smaller, and a little paler than the male. Young differing greatly from the adult, and changing their plumage repeatedly. Moult simple, annual. Colors red, at first white and rose.

Living and migrating in large flocks, frequenting desert sea shores and salt marshes. Extremely shy and watchful: establish sentinels to give warning of danger by a loud sound, and lead their flight. When flying form a triangle, a line when alighting, and especially when fishing. Solitary only 
when advancing inland, where they appear astray. Feed on mollusca, spawn, insects, which they fish up by means of their long neck, turning their bill upside down to take advantage of its peculiar form. Breed socially in inundated marshes : raising the nest to the height of their body, by heaping up the mud with their feet into a hillock concave at top, where they lay and hatch, standing, often in the water: eggs two or three, elongated. Young run swiftly as soon as hatched. Sleep standing on one leg, the neck folded back upon the body, and the head under one wing. In walking assist themselves by placing their upper mandible to the ground. Run swiftly. Never swim from choice. Hearing and smell very acute. Voice trumpet-like.

Spread all over the warm countries of the globe, visiting occasionally the temperate shores. Formed of four species, one of which visits Europe, and one also, North America. May be forced into Herodii in an arbitrary system. By the bill and toes, (not however, like Phalaropus, or even Recurvirostra, by the texture of the plumage,) approaches the Family Lamellosodentati.

28\%. Phenicopterus ruber, L. Red, quills black.

Young, grayish-white.

Red Flamingo, Phonicopterus ruber, Wils. Am. Orn. viii. p. 45. pl. 66. fig. 4. adult; and Nob. Am. Orn. iii. young. Inhabits tropical America; migrating in summer to the southern, and accidentally to the middle states : rare.* black.

* Phœnicopterus antiquorum, Temm. Rose color; wings red; quills

Young, whitish, with strongly marked long brownish blotches.

Le Phœnicoptere, Buffon Pl. enl. 63. adult.

Inhabits the warm regions of the old continent: migrating in summer to southern, and accidentally to central Europe : rare. 


\section{ORDER V. ANSERES.}

Anseres, L. Gm. Pinnatipedes, Palmipedes, Lath. Temm. Grallatores, Natatores, Ill. Vigors. Palmipedes, Cuv. Natatores, Vieill. Ranz. Latr.

BiLl generally short, or moderate. FEET placed more or less back, short, covered by a tender coriaceous skin; tibiæ but partially fleshy, naked for a small space, (genera Phalacrocorax, Tachypetes, Aptenodytes excepted,) tarsi much shorter than the neck, compressed, naked, (half feathered before in Tachypetes only,) reticulated; toes four, or three, palmated or lobated, disposed $3-1,3-0,4-0$; hind toe when present, articulated internally : nails short, in no degree retractile. Body boat-shaped. TarL of from twelve to twenty feathers, or wanting.

Female smaller. Young differing greatly from the adult. Moult generally twice a year. Plumage thick and close, abundantly furnished with down, oily, impermeable : rump having a glandulous apparatus, whence the oil spreads.

Aquatic. Live near water, preferring salt; admirable swimmers. Feed on fishes, insects, mollusca, some on vegetables, diving for their submerged food. Monogamous, though in breeding and rearing various. Nest generally on the ground, often in the cavities of rocks, and even on trees.

Divided into five Families, very natural both as to form and habits.

\section{FAMILY XXIV. LONGIPENNES.}

Longipennes, Cuv. Latr. Longipennes, Tubinares, Vaginati, Ill. Pelagii, Siphorini, Coleoramphi, Vieill. Pelagii, Siforinii, Chionis, Ranz. Idrochelidones, Goldfuss. Larida, Rallida, Vigors.

Voz. II. 
Bisu rather longer than the head, hard, straight, or only curved at the point, compressed, rarely cylindrical, acute : margins entire, sharp; lower mandible more or less navicular, ascending at tip : tongue short, fleshy. Head and neck moderate. Feet almost central; tibia free, not drawn up into the belly, anterior toes moderate, connected by a membrane, sometimes entire, sometimes indented; hind toe small, free, simple, raised from the ground, touching it only at tip, or wanting : nails curved, acute. WINGs very long, acute; two first primaries longest. TaIL rather long, of twelve feathers.

Female hardly smaller, similar in color to the male. Young differing much from the adult, and changing gradually with age.

Aerial : excel in flight. Fly constantly on or about waters, in which all can swim, but the greater part merely sit motionless, resting occasionally on the beach, or on bare poles, never on trees. Unite in flocks, and undertakc periodical journies; decoyed in great numbers around a wounded bird of their kind, or any thing resembling it. Somewhat rapacious: food exclusively animal, fishes, mollusca, eggs, and young water birds; seldom attacking living animals out of their favourite element. Lay without much preparation in the clefts of rocks, among the grass, or on sandy beaches, in holes dug with their feet: eggs from one to four, generally two: sit only during night and stormy weather; both sexes incubate and feed the young; young only leave the nest when fullfledged. Voice harsh, screaming. Flesh tough, bad tasted. Intermediate between the waders, and the diving aquatic birds.

\section{A.}

Bill of one piece. Nostrils immarginate. Feet 4-toed.

Longipennes, Ill. Pclagii, Vieill. Ranz. Lari, Oken. Lari, Sterna, Boì̀. 


\section{RHINCOPS.}

Rhincops, L. Gm. Lath. Ill. Cuv. Vieill. Temm. Ranz.

Rigcopsalia, Barrere, Brisson. Phalacrocorax, Moehring. Bilu longer than the head, straight, almost tetragonal at base, then exceedingly compressed; upper mandible much shorter than the lower, somewhat curved from the base to the point, rather acute at tip, grooved so as to receive the edge of the lower; edges much bent in forming a narrow channel; lower mandible narrower, truncated at tip, lineated obliquely on the sides, with the edges distinct only at base, being so well united as to appear a mere blade, fitting into the channel of the upper : nostrils basal, marginal, concave, oblong, longitudinal, open, pervious: tongue very short, narrow, acute. FEET moderate, slender; tarsus somewhat longer than the middle toe; middle toe longest; inner shorter than the outer; webs emarginate; lateral toes bordered exteriorly with a narrow membrane; hind toe shorter than a phalanx of the middle one, articulated rather high on the tarsus, touching the ground at tip: nails rather elongated, curved, acute; the middle nail twice as long as the lateral; hind nail much the smallest. WINGs extremely long, folding across each other, falcate upwards; first primary longest, and with the second much longer than the others. TAIL of moderate length, forked.

Female similar to the male. Young differing from the adult. Moult twice in the year, but without much changing their appearance.

Keep in small parties near the shores, seldom venturing far at sea. Resting on shores and in marshes: walk awkwardly : seldom alight, hardly ever on the water; never swim. Flight slow, flapping when looking after food, swift and tortuous when it is discovered. Feed on small fishes, and other marine animals, skim the water, ploughing it with their lower mandible, the upper being kept out until the prey is felt by 
the lower. Breed socially on the rocks, or on sandy beaches, without any preparation; lay but once a year ; eggs 3 , oval. Voice strong, harsh, screaming.

Chiefly tropical : found in all longitudes. Composed of but three species.

283. Rhincops nigra, L. Black; beneath white; bill and feet red, the former black at the point.

Black Skimmer, or Shearwater, Rhincops nigra, Wils. Am. Orn.p. 89. pl. 60. fig. 4 .

Inhabits the tropical coasts of America : migrating during summer to the coasts of the United States, where it breeds : not rare in New-Jersey.

\section{STERNA.}

Sterna, L. Gm. Briss. Lath. Ill. Cuv. Vieill. Temm. Ranz. Sterna, Thalasseus, Sternula, Hydrochelydon, Boì̀.

Bilc longer than the head, robust, straight, compressed, more or less subulate, acute; edges sharp, bent in for a space beyoud the middle; upper mandible more or less curved at the point, never hooked; lower equal to the upper, slightly angular beneath : gape wide : nostrils somewhat distant from the base, lateral, longitudinal, linear, pervious : tongue moderate, slender, cleft and acute at tip. Head and neck moderate: body elongated, slender, compressed. Fext small; naked space on the tibia well marked; tarsus shorter than the middle toe: anterior toes slender: the webs more or less indented; lateral toes margined exteriorly with a narrow membrane; outer toes longer than the inner; the middle one longest; hind toe shorter than a phalanx of the middle toe, touching the ground merely at tip; anterior nails curved, acute; middle one thrice as long as the lateral; hind nail extremely short. Wings very long, when folded, crossing each other, extremely falcate, acuminate; first primary longest. TAIL rather long, generally forked. 
Sexes perfectly similar in color. Female a little smaller. Young differing from the adult, but only before their first or second moult., Moult twice in the year, changing the colors of the head only. Plumage silky. Colors white, with bluish tints, with some black; or black with some white. Young skirted with blackish, ferruginous, \&c.

Live in small flocks near water, especially on the sea. Fly almost continually high in the air, playing in difierent directions, or skim the surface of the water, alighting occasionally on the beach, on rocks, or naked poles, but hardly ever on the water : swim awkwardly, and never from choice. Feed on living animals, principally fishes, which they catch by turning rapidly near the surface of the water, or by flying at a moderate height, and darting headlong upon their prey as soon as discovered; the larger and more powerful species prey also on the young of water birds and their eggs : some do not avoid swallowing insects as they fly along, and the weaker pecies feed entirely upon them. Lay socially on the ground, sandy beaches, or on rocks, without the least preparation : eggs few, 2-4; sedulously protect their offspring. Voice sharp, shrill, often repeated, especially in fine weather, when soaring.

Widely spread over the waters of the globe. Closely allied to the following genus, into which they pass insensibly. Analogous to the Swallows.

* White, back wings and tail, pearl-gray.

284. Strrina cayana, Lath. Bill elongated, stout, orange; quill shafts white; tail not much forked; tarsus one inch and a quarter long, black; webs entire.

Summer plumage, whole crown black : winter, hind head only marked with black.

Cayenne Tern, Sterna cayana, Nob. Am. Orn iii. pl.

Inhabits the tropical seas of America: common on the coasts of the southern states. 
285. Sterna Aranea, Wils. Bill very short, stout, black; quill shafts white; tail slightly forked; tarsus one inch and a half long, black, equal to the middle toe; webs deeply indented; hind nail straight.

Summer plumage, crown deep black : winter, crown white, a black spot each side of the eye.

Marsh Tern, Sterna aranea, Wils. Am. Orn. viii. p. 143. pl. $72 \cdot f i g \cdot 6$.

Inhabits both continents, and is found in both hemispheres: not rare during summer on the coasts of New-Jersey, where it breeds.

236. Sterna hirundo, L. Bill long, slender, red tipped with black; crown black; quill shafts white; outer vane of the first primary bluish-white; tail greatly forked; tarsus red, nearly one inch long; webs entire.

Adult, both in summer and winter, crown black.

"Young dingy white, varied with gray, brown and rufous; hind head only marked with black.

Great Tern, Sterna hirundo, Wils. Am. Orn. vii. p. 76. 60. $f i g \cdot 1$.

Inhabits both continents : common during summer on the coasts of the northern and middle states, where it breeds.

פS\%. Stenna arctica, Temm.* Bill moderate, very slender, red to the tip; crown black; quill shafts white; outer vane of the first primary black; tail greatly forked; tarsus three quarters of an inch.

* The back and wings are still paler than S. Hirundo, (and by no means darker, as Temm. states) in our specimens. It may be somewhat doubtful, whether this species is Sterna Arctica, Temm. (macroura of Germ. Orn.) as it does not well agree with their description; it coincides better with S. argentata, Brehm. but not precisely even with that; we, however, think them all one and the same. 
Adult, both in summer and winter, crown black.

Young as the preceding.

Arctic Tern, Sterna arctica, Nob. Am. Orn. iv. pl. Sterna argentata, Brehm.

Inhabits the north of both continents : not rare in autumn on the coasts of New-Jersey.

288. Sterna minuta, L. Bill long, slender, orange, black at tip; crown black ; front white; quill shafts black ; tail greatly forked; tarsus half an inch long; webs entire.

Young somewhat dingy and spotted; black of the head obsolete.

Lesser Tern, Sterna minuta, Wils. Am. Orn. vii. p. 80. pl. 60. fig. 2 .

Inhabits the north of both continents, extending widely; common during summer on the coasts of the northern and middle states, where it breeds. Closely resembling Sterna argentea, P. Max. Neuv. from which our phrase distinguishes it.

\section{* Black, or blackish.}

289. Sterna migra, L. Bill slender, black; tail slightly forked; tarsus five eighths of an inch; webs deeply indented.

Summer plumage, wholly blackish-cinereous : winter, plumbeous, head and neck deep black; front, throat and vent, white.

Young white; hind head blackish; back, wings and tail, brownish, skirted with dingy-whitish.

Short-tailed Tern, Sterna plumbea, Wils. Am Orn. vii. p. 83. pl.60. fig. 3. young; and Black Tern, Sterna nigra, Nob. Am. Orn. iv. pl. adult.

Inhabits both continents : common during autumn on the coasts of New-Jersey.

290. Sterna fuliginosa, $\mathrm{Gm}$. Bill black; front, exterior edge of the outer tail feathers and all beneath, white; tail deeply forked; webs entire. 
Sooty Tern, Sterna fuliginosa, Wils. Am. Orn. viii. p. 145. pl. 72. fig. $\%$.

Inhabits the tropical seas : common during summer on the southern and south-eastern coasts of the United States.

291. Stenna stolida, L. Bill black; crown whitish; tail rounded; webs entire.

Noddy, Sterna stolida, Nob. Am. Orn. iv. Hirondelle de mer brune de la Louisiane. Buff. pl. enl. 99\%.

Inhabits all parts of the tropical seas, migrating occasionally to the North American coasts : not very rare.

\section{LARUS.}

Larus, L. Briss. Gm. Lath. Ill. Cuv. Ternm. Vieill. Ranz. Larus, Gavia, Xema, Boiè.

BiLl moderate, robust, hard, straight, compressed, naked at base, edges bent inward, sharp; upper mandible rounded ajove, curved at the point, sharpish; lower somewhat shorter, gibbous and angular beneath the point, obliquely truncated at tip : nostrils medial, lateral, longitudinal, linear, wider and rounded anteriorly, open, pervious : tongue acute, hardly cleft at tip. HEAD rather large; eyes moderate; neck moderate, stout; body plump, compressed. FeET moderate, rather slender; tarsus nearly equal to the middle toe; webs entire; lateral toes margined exteriorly with a narrow membrane; middle toe longest, but of moderate length ; outer longer than the inner; hind toe very small, articulated high and posteriorly with the tarsus, raised from the ground: nails small, curved, rather acute, dilated interiorly into an edge; middle twice as large as the others; hind nail sometimes wanting. Wings long, acute ; quills stiff; first and second primaries subequal, longest. TAIL almost always even, of twelve feathers.

Female somewhat smaller, but perfectly similar in color to the male. Young for several years, the larger species four or five, very difierent from the adult. Moult twice a 
year, changing the colors of the head only; the young moulting continually. Plumage silky, elastic, plentifully supplied with down. Colors, including the tail, always pure white, with a distinct mantle; mantle white, pearl-gray, or deep slate-black. Young mottled with dull gray and various tints of brownish, confusedly spotted, passing by infinite gradations; bill, feet and iris, dark; light in the adult.

Timid : cowardly except in defending their young. Very numerous, covering whole shores. Keep generally in large flocks, the young and old separate, the larger species on the sea, the smaller along rivers and lakes. Alight on rocks, beaches, or on the water. Walk tolerably well: swim with ease ; incapable of diving. Keeping much upon the wing; flight rapid, straight, equal, long sustained, even against the strongest gales. Contract their neck and draw one foot up when resting. Voracious: espying and fighting against their own species for prey; attacking each other without any apparent reason. Fall on and devour the wounded. Patient of hunger. Feed on every kind of animal food, dead or alive, fresh or putrid. Great purgators-sea Vultures; the larger species prey on eggs and young birds; but all principally on fishes, of which they follow the shoals, catching them with great agility on the surface of the sea, by darting like an arrow, and submerging their head; digesting scales, feathers, and even putrid matter; when irritated disgorge their undigested food. Breed once a year only, principally in desert places, Arctic islands, on naked rocks, or on marshy weeds, with little preparation : eggs from 2 to 4 , generally 3. Young leaving the nest soon after exclusion, but hiding carefully, and fed for several weeks by their parents. Clamorous: voice loud, shrill, often repeated while flying. Flesh tough, bad tasted. Feathers valuable.

Spread all over the world. Species numerous, resembling each other greatly in all their difierent states of plumage.

Vor. II. 
292. Larus mrnutus, Pallas. Mantle pearl-gray; quills white at the point, shafts blackish; tarsus one inch long; hind toe very small, nail straight, hardly apparent.

Summer plumage, a black hood : winter, no hood.

Young spotted with cinereous and blackish, tail somewhat forked, with a black subterminal band.

Little Gull, Latham. Larus minutus, Gm. Lath. Sabine. Naum. Vog.t. 3. f. 72. adult in full dress.

Inhabits the north of both continents : very seldom seen in the United States, common in Asia and eastern Europe.

293. Larus caprstratus, Temm. Mantle pearl-gray; quills black at the point, outer white, internally pale ash; shafts white; bill very slender'; tarsus less than one inch and a half; tail sub-emarginate.

Summer plumage, head only with a light-brown hood: winter, no hood.

Young spotted with grayish and blackish; tail with a black subterminal band.

Brown-masked Gull, Larus capistratus, Nob. Am. Orn. iv. $p l$.

Inhabits the north of both continents : not very rare during autumn on the Delaware, and especially the Chesapeake; found as far inland as Trenton: very rare on the coasts of Europe. Together with the preceding, unite the genera Larus and Sterna. Closely allied, and extremely similar to Larus ridibundus of Europe, hardly distinguished but by its smaller size, and its still more slender, Tern-like bill.*

* Larus ridibundus, L. Mantle pearl-gray ; quills black at the point ; outer white; internally blackish; shafts white; bill slender; tarsus on $\odot$ inch and three quarters; tail slightly rounded.

Summer plumage, head and part of the neck, with a dark brown hood; winter, no hood.

Young spotted with brownish and yellowish, tail with a black subterminal band. 
294. Larus atricilia, L. Mantle dark bluish-ash; quills entirely black; bill robust, and with the feet dark red; tarsus nearly two inches.

Summer plumage, a dark plumbeous hood on the head and neck, descending lower before : winter, no hood.

Young brownish skirted with whitish and rusty; tail with a black subterminal band.

Black-headed Gull, Larus ridibundus, Wils. Am. Orn. ix. p. 89. pl. 74. fig. 4 .

Inhabits both continents, found throughout North America, very common during summer and autumn on the coasts of New-Jersey, where it breeds: found also on the south-western coasts of Europe.

295. Larus tridactrets, L. Mantle blue-gray; quills black at the point; hind toe obsolete, destitute of nail.

Summer plumage, head and neck pure white: winter, head and neck bluish-gray; fine black lines before the eye.

Young dingy, spotted; tail with a black subterminal band.

Kittiwake Gull, Latham. Wilson's list. Buff.pl. enl. 38\%。

Inhabits the north of both continents.

296. Larus canus, L. Mantle bluish-gray; quills black at the point, reaching much beyond the tail; shafts black; bill small; feet bluish; tarsus little more than two inches.

Summer plumage, head and neck pure white : winter, head and neck with blackish spots.

Young brownish-cinereous, varied with rusty.

Common Gull, Lath. Wilson's list. Buff.pl. enl.97\%.

Inhabits both continents: common: numerous during winter in the middle states.

Buff.pl. enl. 9\%0. summer dress, 969 winter dress.

Inhabits throughout Europe and northern Africa : very common at Rome. Said to be found also in North America, by respectable authorities: never ascertained by us. 
297. Larus eburneus, $\mathrm{Gm}$. Pure white; bill stout; feet black; naked space above the tarsus very small; webs somewhat indented; tarsus one inch and a half; first primary longest.

Young dingy cinereous, somewhat mottled.

Ivory Gull, Lath. Buff.pl. enl. 994.

Inhabits the Arctic circle, whence it migrates occasionally to the temperate regions of both continents. Forms another transition to Sterma, by its feet and wings.

298. Larus fuscus, L. Mantle slate black; quills almost entirely black, reaching two inches beyond the tail; bill short, not stout ; feet yellow; tarsus two and a half inches.

Sumıner plumage, head and neck pure white : winter, head and neck streaked with light brown.

Young, blackish cinereous, mottled with yellowish-rusty.

Silvery gull, Lath. Meyer Vog. Deutsch. ii.pl. 18.

Inhabits both continents : very common during winter near Philadelphia and New-York.

299. Larus argentatoines, Brehm. Back and wings bluishgray; quills black at the point, tipped with white, reaching but little beyond the tail ; shafts black ; first primary broadly white at tip; second with a round white spot besides; tarsus less than two and a half iuches; nostrils oval. Length twenty inches.

Summer plumage, head and neck pure white : winter, head and neck streaked with brown.

Young, dirty mottled, varied with rusty.

Notnoticed in my Catalogue. Somewhat doubtful whether it is Brehm's species.

Inhabits both continents : common near New-York and Philadelphia. We have shot it also on the southern coasts of England.

300. Larus argentatus, Brunn. Mantle bluish-gray; quills 
black at the point, tipped with white, reaching much beyond the tail ; shafts black; first primary only, with a white spot besides the narrow tip ;* tarsus nearly three inches; nostrils linear. Lengrth two feet.

Summer plumage, head and neck pure white: winter, head and neck wilh brown lines.

Young blackish cinereous, mottled with yellowish-rusty.

Herring Ciull, Lath. Wilson's list. Buff. pl. enl. 253. Larus argenteus, Macgillivray; (who, however, evidently considers this and the prectding but one species.) Larus argentatus, and Larus argenteus, Brehm, (which I do not thinte distinct.)

Inhabits both continents : not uncommon near New-York and Philadelphia, as well as in Italy.

301. Larus leucopterus, Faber. Mantle pale bluish-ash; quills grayish-white, white at the point, reaching to the tip of the tail; shafts pure white; tarsus two inches.

Summer plumage, head and neck pure white : winter, head and neck streaked with brown.

Young dingy, mottled.

Larus glaucoides, Temm. Larus argentatus, Capt. Sabine. Larus arcticus, Macgillivray. Omitted in my catalogue. Never figured.

Inhabits the Arctic circle, whence it migrates in winter to the boreal regions of both continents, advancing farther south in America : not rare in the northern and middle states.

302. Larus glaucus, Brunn. Mantle bluish-gray; quills grayish-white, white at the point; shafts white, tinged with

* Though $I$ have found them constant in all the Italian, English, and North American specimens of both species that I have examined, I cannot give these markings as sure tests of the two species, which, however, are certainly distinct, and though closely allied, may at once be distinguished by the size. 
ash; tarsus three inches; tail reaching two inches beyond the wings.

Summer plumage, head and neck pure white : winter, head and neck with brown streaks.

Young dingy, mottled.

Glaucous Gull, Lath. Naum. Vog.pl. 35.

Inhabits the Arctic regions of both continents : exceedingly rare in the United States.

303. Larus marinus, L. Back and wingsslate-black; quills black at the point, tipped with white; shafts black; wings not reaching beyond the tail; tarsus three inches.

Summer plumage, head and neck pure white : winter, head and neck with brownish streaks.

Young dingy, mottled.

Black-backed Gull, Lath. Wilson's list. Buff.pl. enl. ̈̈90. and 266. young.

Inhabits both continents: not uncommon during winter in the middle states.

B.

Bill of several pieces. Nostrils immarginate. Feet 4-toed.

Longipennes, Ill. Pelagii, Vieill. Ranz. Lari, Boie.

\section{LESTRIS.}

Larus, L. Gm. Lath. Buphaga, Moehring. Catharracta, Brunn. Stercorarius, Briss. Vieill. Lestris, Ill. Cuv. Temm. Labbes, Buff.

BiLL moderate, robust, hard, cylindrical, compressed, hooked at tip, edges sharp; upper mandible with the ridge and tip distinct, covered beyond the nostrils by a cere; lower of one piece, shorter, angular beneath, obtuse at tip : nostrils subterminal, lateral, oblique, linear, wider before, pervious, 
closed posteriorly by the cere : tongue canaliculated, acute, slightly bifid at tip. Head large; eyes large : neck rather stout : body rather plump. FEET slender; naked space of the tibia moderate; tarsus equal to the middle toe, scaly behind; webs full, entire; lateral toes edged exteriorly with a narrow membrane; middle toe longest; inner shorter than the outer; hind toe very small, placed almost on a level with the anterior, resting on the ground: nails strong, much incurved, very acute. Wings moderate, acute; quills strong; first primary longest. TAIL slightly rounded, of twelve feathers, two middle feathers elongated.

Female similar to the male. Young differing from the adult, and changing repeatedly. Moult twice in the year without changing their colors. Colors dark brown, with some white or light tints on the neck and beneath. Young more spotted, and with the middle tail feathers hardly longer. Adult eminently distinguished by having these feathers much the longest.

Bold : fierce : indefatigable. Tyrants of the sea. Solitary, seldom several in one neighbourhood. Extremely voracious : feed on fishes, which are caught by other birds. Great enemies to the Terns, Gulls, and even the gigantic Albatros, on which they prey; attacking them on the wing, and beating them until they drop their prey, or even forcing them to disgorge their food, which they seize in the air with great agility before it reaches the water, the Gulls only escape by settling in the sea. Nerer diving, only procure themselves floating objects; feed also on mollusca, eggs, and young water birds. Breed socially in Arctic marshes, on rocks, or among sands: build in tufts with grass: eggs one or two : courageous in behalf of their young; attacking man himself in their defence. Walk erect. Flight peculiar, irregular, rapid, describing short curves, and occasionally tumbling over.

Inhabit the Arctic seas all around the globe, migrating but 
little to southern regions. Formed of but our four spe cies. Though united with Larus by authors, very distinct from them in nature, and perhaps claiming less alliance with them than with Procellaria and Diomedea. Somewhat analogous to the Eagles.

304. Lestris catarractes, Ill. Bill short, very stout, much curved; middle tail feathers equally broad throughout; tarsus two inches and three quarters long, moderately rough.

Adult dark brown, neck and beneath grayish rufous.

Young wholly brownish varied with rusty.

Skua Gull, (Wilson's list?) Lath. Penn. Brit. Zool. t. L. fig. 6 .

Inhabits the most northern parts of both continents, migrating occasionally during winter to the temperate regions.

305. Lestris pomakina, Temm. Bill short, much curved; long tail feathers equally broad throughout; tarsus little more than two inches long, exceedingly rough.

Adult dark brown, beneath white; feathers of the neck above long, slender, pointed, glossy yellow.

Young wholly brownish, varied with rufous.

Larus parasiticus, Meyer. Vog. Deut. ii. pl. 21.

Inhabits the Arctic circle, whence it migrates in winter to more genial regions : very rare and accidental in the United States.

306. Lestris buffonit, Boié. Bill one inch and a quarter from the front, straight, notched; middle tail feathers gradually tapering, narrow for several inches, ending in a point ; tarsus one inch and a half long, almost smooth.

Adult brown, neck and beneall white, the former tinged with yellow.

Young wholly brownish.

Arclic Bird, Edward's Glean. pl. 148. Buff. pl. enl. 762. Lestris crepidata, Brchm. Not noticed in my Catalogue. 
Inhabits the Arctic seas, migrating during the winter to the temperate shores of North America and Europe: very rare and accidental in the United States, where the young only have been observed.

30\%. Lestris parasitica, Boie. Bill one inch and a half long, straight, broad at base, entire ; middle tail feathers very long, still wide one inch and a half from the tip, abruptly narrowing, slender and acute at the point; tarsus one inch and three eighths long, protuberances obsolete.

Adult blackish-brown, neck and beneath white, the former tinged with yellow.

Young wholly brownish.

Arctic Gull, Lath. Die Polmëue, Lepechin's Reise. Th. 3. S. 224. $t$. 11 .

Inhabits the Arctic seas, migrating during winter on the temperate shores of North America and Europe. Rare, and the young only occasionally seen near the United States.

C.

Bill of several pieces. Nostrils tubular. Feet 3-toed, or in place of the hind toe, a sharp nail.

Tubinares, Ill. Syphorini, Vieill. Ranz. Procellarice, Boie, Syphonorhini, Blainville.

$$
\text { * A sharp hind nail. }
$$

Procellaria, auct. Procellaria, Pachyptila, Ill. Temm. Ranz.

\section{THALASSIDROMA.*}

Procellaria, L. Briss. Gm. Lath. Ill. Cuv. Vieill. Ranz.

* This genus and Puffinus are not mentioned in our Analytical Table, as we considered them subgenera of Procellaria, but have since decided to adopt thern as genera. See note (26.)

VoL. II. 


\section{Thalassidroma, Vigors. Hydrobates, Boie.}

Petrel-Hirondelle, Temm.

Bilc shorter than the head, slender, feeble, attenuated, extremely compressed, hooked at the point, acute ; edges sharp, greatly approximated; upper mandible slightly seamed each side: lower shorter, hardly angular beneath, more or less curved and acute at tip, end hardly distinct: nostrils contained in a single tube on the top of the bill: tongue moderate, depressed, entire, slender, acuminate, acute. Head small, rounded above; eyes large ; neck short : body slender. Feet long, slender; naked space of the tibia extensive; tarsus longer than the middle toe, slender, perfectly smooth; toes rather short, slender; middle toe subequal to the outer; inner shortest; the lateral margined exteriorly by a narrow membrane; webs small, somewhat indented; hind toe merely a slender, acute nail: nails small, rounded above, in one species quite flat and laminar, but generally curved, compressed, and acute. Wings long, acuminate; first primary shorter than the third;* second longest. TaIL emarginate, or slightly forked, of twelve feathers.

Fenale similar to the male. Young hardly differing from the adult. Moult twice a year without changing their colors. Colors black, with more or less of white, especially on the rump. Species very small : the smallest of web-footed birds.

Semi-nocturnal : wandering. Seen all over the ocean at wonderful distances from land, principally at twilight, or in stormy weather; hiding from the sun in clefts of rocks, or in the burrows of quadrupeds. Feed on small marine animals and seeds of sea-weeds; very fond of greasy substan-

* The character assigned by Mr. Vigors, of the first primary being longer than the fourth, though perfectly correct as to $P$. pelagica, cannot stand as generic, since in P. Leachii, it is shorter. We have not been able to verify the character on $\mathrm{P}$. Wilsonii, the specimens we examined for that purpose being in moult. 
ces, for which, more than for protection, they follow vessels under way, playing in their wake, where they pick up the animals put in motion, and the floating weeds. Breed socially in holes and cavities of rocks overhanging the sea : lay one or two eggs. Feed their young by regurgitation. Rest easily on the water, suspending their light bodies on the top of the waves with extended wings, riding on them, touching with their feet. Flight rapid, irregular, always low and skimming the water in day time. Voice chattering : silent during the day; clamorous at night.

Spread in all latitudes and longitudes. A small and exceedingly natural genus, formed of but five well, ascertained species, so closely allied to each other, as to be generally confounded. Resembling the Swallows.

Differs from Procellaria, as Lestris from Larus.

308. Thalassidroma wilsonir, Nob. Deep sooty black; upper tail coverts wholly white; tail even, the wings reaching a little beyond its tip; tube of the nostrils recurved; tarsus one inch and a half long; a yellow spot on the webs.

Stormy Petrel, Procellaria pelagica, Wils. Am. Orn. vii. p. 90. pl. 60. Procellaria wilsonii, Nob. J.Ac. Ph. vi. p. 231 . pl. 9. lower figure.

Inhabits throughout the tropical and temperate Atlantic Ocean, not extending far to the north; more common on the coasts of the southern states and on the banks : found also on the coasts of Africa, and even those of Spain, thus entitled to a place in European Ornithology.

309. Thalassidroma leachir, Nob. Brownish-black; upper tail-coverts white, with dusky shafts; tail forked, the wings not reaching beyond the tip; tube of the nostrils straight; tarsus one inch long.

Procellaria Leachii, Temm. Nob. J. Ac. Ph. vi. p. 229. pl. 9. upper figure. Fork-tail Petrel? Procellaria furcata? Lath. (27.) 
Inhabits throughout the Atlantic Ocean : not rare on the banks of Newfoundland, and in the northern British islands.

\section{PROCELLARIA.}

Procellaria, L. Gm. Lath. Briss. Ill. Cuv. Vieill. Ranz.

Procellaria, Boie. (as restricted.) Petrel propr. dit, Temm. Bill as long as the head, robust, broad, hard, sub-cylindrical, depressed at base, compressed and suddenly swelled towards the point, edges sharp: upper mandible deeply seamed each side, strongly hooked and acute at tip; lower shorter, narrower, ascending, angular beneath, truncated at tip, with the end very distinct: nostrils united in a common tube on the top of the bill : tongue moderate, entire, conic. Head large, somewhat rounded above; eyes rather large; neck short, thick: body rounded, plump. FeEt stout, moderate; naked space of the tibia much restricted; tarsus shorter than the middle toe; toes very long; middle one subequal to the outer; inner shortest; the lateral edged exteriorly by a narrow membrane; webs full, entire, large; hind toe merely a thick and obtuse nail: nails large, curved, compressed, acute, channelled beneath, middle one largest, dilated internally into a sharp edge. Wings very long, acute ; quills numerous; first primary longest. TAIL of fourteen feathers, rounded or cuneiform.

Female similar to the male. Young differing but little from the adult. Moult twice a year without changing their colors. Species large. Prevailing color white.

Diurnal. Keep generally far at sea among rocks and icebergs, seldom approaching the shore. Venturing farther than any other bird, regardless of heavy seas and gales: most active and numerous when a storm is approaching. Fly, rest, and even walk on the waves. Flight with the wings expanded, motionless. Feed on fishes, the flesh of dead cetacea, mollusca, and other marine animals, and even vegetables. Breed in great companies in the clefts of Arctic rocks, 
or in holes in the earth, where they also retire during bad weather; lay but one very large egg. Feed their young by regurgitating into their bill their half digested and oily marine food. Defend their offspring boldly, and blind their enemies by spurting in their face an oily, acrimonious liquor. Voice hoarse, stridulous, singular when subterranean.

Found in all latitudes. Formed of but few species, one only in our hemisphere. Allied to the larger Gulls.

310. Procellaria gracialis, L. White; back and wings bluish-gray; tail cuneiform; bill and feet yellow.

Summer plumage, a blackish spot before the eye.

Young pale-cinereous, varied with brown; bill and feet yellowish-gray.

Fulmar Petrel, Lath. Penn. brit. zool.p. 145.t. M. fig.1.

Petrel de l'Isle de St. Kilda, Buff. pl. enl. 59.

Inhabits in great numbers the Arctic seas; very rare and accidental on the temperate coasts of North America and Europe.

\section{PUFFINUS.}

Puffinus, Briss. Cuv. Boie. Brehm. Nectris, Forst. PetrelPuffin, Temm. Procellaria, L. Gm. Lath. Ill. Temm. Vieill. Ranz.

BiLL longer than the head, slender, robust, hard, much compressed at the point; both mandibles much curved and acute at tip; upper seamed each side, turgid at the point; lower somewhat shorter, angular beneath, with the end very distinct: nostrils basal, opening in two tubes, approximated and dorsal : tongue moderate, entire, conic. Head small, narrowed behind; eyes very large : body compressed. FEeT moderate, stout, large; naked space of the tibia extensive; tarsus equal to the middle toe; toes long; middle one subequal to the outer; inner shortest; the lateral margined exteriorly 
by a narrow membrane; webs full, entire; hind toe merely a sharp nail: nails long, compressed, curved, acute. Wrngs long, slender, rather acute; first primary longest. TAIL moderate, rounded, of twelve feathers.

Female similar to the male. Young but little different from the adult. Moult twice a year without changing their colors. Colors more or less grayish. Species of middling size.

Chiefly nocturnal : chasing at twilight, or in stormy days, and hiding from the sun in clefts of rocks, or in the burrows of small quadrupeds, which they dislodge. Much more aquatic than any bird of their family; combine the powers of flying and diving. Keep on the wing for several days, and dive even for their food, escaping from danger by either means. Constantly at sea, residing among breakers, hardly ever seen on shore. Feed almost exclusively on fishes. Breed socially: dig with their sharp nails deep holes in the ground, where they lay but one egg. Young born with long down. Furnish the wretched inhabitants of the Frozen Zone with food and clothing.

Spread all over the world. A natural genus, eminently distinguished by its power of diving, much less allied than it appears to Procellaria. Forms the link between the Longipennes, and the diving web-footed birds.

311. Puffinus cinereus, Cuv. Bill more than two inches long, depressed at base, compressed where the point swells; tail cuneiform; tarsus two inches long.

Adult light cinereous, wings and tail blackish-ash; beneath white; bill and feet yellowish.

Young slate-color, beneath varied with cinereous; bill blackish.

Cinereous Petrel, Lath. Le Puffin, Buff.pl. enl. 962. young. Shear-water Petrel of Wilson's list? Procellaria puffinus and cinerea, $\boldsymbol{L}$. 
Inhabits the sea throughout the globe: common between the banks of Newfoundland and the United States, in the Mediterranean, \&c.

312. Puffinus anglorum, Ray. Bill one inch and three quarters long, very slender; tail rounded, the wings reaching somewhat beyond its tip; tarsus little more than one inch and three quarters long.

Adult glossy black, beneath pure white; bill blackish.

Shear-water Petrel, Penn. nec Lath. Manks Puffin, Edwards, t. 359. Procellaria anglorum, Term. Meyer. Omitted in my catalogue.

Inhabits the Arctic seas of both continents : rare and accidental in the United States, very common in the northern British islands.

313. Purfinus obscurus, Cuv. Bill one inch and a quarter long, very slender ; tail rounded, the wings reaching to its tip ; tarsus little more than one inch long.

Adult glossy brownish-black, beneath white : bill blackish. Dusky Petrel, Lath. Penn. St. degli Ucc. V.pl. 538.

Inhabits throughout the temperate and warm seas, never to the north : very rare and accidental in the middle states and Europe. Not easy to distinguish from the preceding.

** No hind nail.

Diomedea, Haladroma, Ill. Temm. Ranz.

70. DIOMEDEA.

Diomedea, L. Briss. Gm. Lath. Ill. Cuv. Vieill. Temm. Ranz.

Bist longer than the head, very robust, hard, compressed, straight, suddenly curved at the point; edges cutting; upper mandible deeply seamed each side, strongly hooked at lip, palate with two or three raised, cutting, serrated 
processes; lower mandible smooth, end distinct, compressed and truncated at tip, internally on each side with a serrated, sharp process : nostrils in the furrow, distant from the base, separate, covered on the sides, open before ; tubes very short, subconical, wider before than behind, lying on the sides of the bill; tongue very short, fleshy, truncated at tip. Head large; eyes large, near the top: neck short, stout: body massive. FEeT short, robust : tarsus one fourth shorter than the middle toe; toes very long; the middle one subequal to the outer; inner shortest; the lateral edged exteriorly by a narrow membrane; webs full, entire; no rudiment of hind toe nor nail: nails short, obtuse. Wings very long, very narrow: quills short; secondaries hardly reaching beyond their coverts. TAII moderate, rounded, of fourteen feathers.

Female similar to the male. Young differing much from the adult. Moult twice a year, without changing their colors. The largest of marine birds.

Notwithstanding their strength and gigantic stature, very cowardly; escape from the attacks of other birds, even considerably weaker, by descending rapidly and settling in the sea; even the Gulls in small parties incessantly attack. and harass them. Voracious beyond conception. Feed on fishes, especially of the flying kind, on mollusca, and above all, gelatinous animals. Gorging themselves to such a degree as to be often unable either to fly or swim, being sometimes seen with large fishes partly hanging out of their mouth, partly swallowed, in which state their feathered enemies compel them to disgorge their food, and they may be caught by hand. Build with clay a rounded nest two or three feet high : eggs very large, numerous for the family. Fly skimming the water, soaring to the high regions of the atmosphere during strong gales and stormy weather only. Venturing great distances from land, occasionally compelled to seek repose, and even to sleep on the sea, or on the rigging of vessels. 
Voice harsh, somewhat resembling the braying of an ass. Flesh tough, badly tasted, hardly palatable even to starving men. Eggs eatable.

Spread throughout both hemispheres, but especially the southern. Formed of but four well ascertained species, only one of which is seen on the Atlantic. Remarkably allied to the larger species of the genus Larus.

314. Dromedea exulans, L. Whitish; back and wings lineated with black; quills black, shafts yellow ; tail plumbeous, rounded.

Young dusky; head, wings and tail, blackish; round the eye white.

Albatros of Wilson's list. Wandering Albatros, Lath. ad. Sooty, or Brown Albatros, Lath. young. Buff.pl.enl. $23 \%$.

Inhabits the Atlantic and Pacific Oceans : rare and accidental on the coasts of the middle states: common at the Cape of Good Hope and in South America.

\section{FAMILY XXV. LAMELLOSODENTATI.}

Lamellosodentati, Ill. Serrirostres, Dumeril. Lamellirostres, Cuv. Latr. Anseride, Goldfuss. Dermorhynchi, Vieill. Ranz. Anates, Oken. Cygni, Anseres, Anates, Mergi, Boie. Colymbini alati, Blainville. Anatida, Leach Vigors.

BrLL moderate, stout, straight, covered with a soft membranous skin, rounded above, depressed, rounded and obtuse at the point, unguiculated at tip, margins denticulated; nostrils distinct, a little distant from the base, superficial, oblong, half closed by a flat membrane; tongue thick, fleshy. Head small; neck various: body plump. FeET 4-toed, nearly central, drawn up into the belly, turned outward, short ; tibia almost entirely feathered; tarsus short; toes disposed 3-1, anterior palmated; webs full, entire; hind toe free, short, nails curved, compressed, acute. WINGs moderate, acute; quills strong, stiff; first primary subequal to the Vox. II. 
second, which is generally longest. TaIL short, of from twelve to twenty feathers.

Female smaller, in many species différing greatly, and far less brilliant than the male. Young very different from the adult, resembling the female, sometimes not getting their full dress until the second or third year.

Gregarious, except in breeding time, when they pair, and then prefer fresh water; during winter and autumn affecting the sea coasts. Feed on fishes, reptiles, mollusca, insects, some species also on vegetable substances, especially seeds, getting their food from the shore or from under water, by means of their sensible bill. Monogamous : build on the ground: eggs numerous, of one color. Female only incubating. Young leave the nest, swim, and provide for themselves as soon as hatched, the parents merely leading and protecting them. Walk in a vacillating and embarrassed manner. Swim with great facility and much grace, some with agility above or beneath the surface, many plunging merely their head under water, when searching for prey, while others submerge their entire body, and continue under for a long period. Flight rapid, sustained for several days at a time. The greater part easily tamed. Highly useful to man : flesh and eggs excellent : down employed for several uses; feathers most valuable of all, best for graphic purposes.

\section{A. Bill stout, depressed, obtuse.}

\section{ANSER.}

Anser, Briss. Bechst. Meyer. 1ll. Vieill. Brehm. Anser, Cygnus, Cuv. Anas, L. Gm. Lath. Temm. Ranz. Oie, Temm. Plectropterus, Cygnus, Anser, Chenalopex, Bernicla, Cheniscus, of modern English authors. Tadorna, Bernicla, Cheu, Anser, Boie.

BiLl short or moderate, stout, at base higher than broad, somewhat conic, cylindrical, depressed towards the point, 
narrowed and rounded at tip, end of both mandibles distinct; upper mandible not covering the margins of the lower, ridge broad, elevated; nail sub-orbicular, curved, obtuse; lower plane; marginal teeth short, conic, acute: nostrils medial, lateral, longitudinal, large, elliptic, open, pervious, covered by a membrane; tongue thick, fleshy, fimbriated on the sides. Head small, lora feathered; neck moderate : body cylindrical. FEET central, stout; tarsi rather longer than the middle toe; toes moderate; webs full, entire; hind toe equal to a phalanx of the middle, simple, touching the ground at tip ; middle toe longest; outer longer than the inner : nails falculate, the middle dilated into a sharp edge. Wings moderate, acute, sometimes spurred; quills strong, primaries much longer than the secondaries; first and second, or second only, longest. TaIL of numerous feathers, rounded.

Female similar to the male. Young of some species differing extremely from the adult, and changing repeatedly. Moult annual, but protracted. Plumage moderately thick. Colors dull, more or less of light, or very dark, cinereous. Size large. Trachea simple.

Habits terrestrial : keep in flocks, mostly in marshes and low grounds, and migrate according to season, from cold to temperate regions. Shy : cunning : vigilant: when sleeping or feeding, establishing sentinels to give warning of any danger. Altogether diurnal. Retiring at night to the water : very clamorous when uniting: go to pasture by day; feed principally on vegetables, which they uibble off, on roots and seeds; some also on fishes, reptiles, and small aquatic animals : commit great devastation in corn-fields, by cutting or rooting up the young plants. Disposed to polygamy. Build on the ground. Walk with less awkwardness than the allied genera. Swim but little, and deeper in the water, neither their body, feet, nor plumage being calculated for it : hardly ever dive, and never by choice. Flight exceedingly high, 
slow, but long sustained; fly either in straight or convergent lines. Sight and hearing excellent.

Spread all over the world, but much more numerous in cold and temperate countries, to and from which they migrate. Species numerous.

315. Anser hyperboreus, Pallas. Bill rising high upon the forehead ; sides of the bill with longitudinal furrows and denticulations; tail of sixteen feathers.

Adult white, quills black at the point : bill and feet red.

Young purplish-brown; wing-coverts and rump, bluish-ash; more or less white according to age.

Snow Goose, Anas hyperborea, Wils. Am. Orn. viii.p. 76 . pl. 68. fig. 5. adult male; and p. 89. pl.69. fig. 5. young. Anser niveus, Briss. Anas hyperborea and carulescens, L.

Inhabits within the Arctic circle; migrating during winter to the more temperate regions of both continents : not uncommon during winter in the middle states.

316. Anser albifrons, Bechst. Brownish, beneath white varied with black ; frontlet and throat white, margined with blackish; bill and feet orange; nails whitish.

White-fronted Goose, Lath. Laughing Goose, Edward's Glean. t. 153. Anas albifrons, Gm.

Inhabits the Arctic regions, migrating during 'winter to the temperate climes of both continents : rare and accidental in the middle states, as well as in Italy.

317. Anser segftum, Meyer. Dark cinereous, beneath whitish; rump blackish ; folded wings reaching beyond the tail; bill long, depressed, black and orange, nail black, tail of eighteen feathers.

Bean Goose, Latham. L'oie sauvage, Buff.pl. enl. 985. Anas segetum, Gm. Anser sylvestris, Briss.

Inhabits the Arctic regions of both continents, migrating periodically to more genial climates : hardly ever seen even 
in the northern states or Canada, which is rather extraordinary, as in the old continent, it migrates much farther south.*

318. Anser canadensis, Vieill. Dark ash; head, neck and tail black; cheeks and throat white; bill and feet black; tail of eighteen feathers.

Canada Goose, Anas canadensis, Wils. Am. Orn. viii. p. 52. pl. 67. fig. 4. Bernicla canadensis, Boie.

Inhabits North America: common during winter in the middle states : domesticated in both continents, and producing mongrels with Anser cinereus.

319. Anser leucopsis, Bechst. Dark cinereous; neck and tail black; face, and beneath from the breast, white; bill and feet black.

Bernicla or Clakis, Lath. La Bernache, Buffon, pl. enl. 885. Anas leucopsis, Temm. Anas erythopus, L.

Inhabits the Arctic circle, migrating during winter to more

* 1. Anser cinereus, Meyer. Light cinereous, beneath whitish; rump cinereous; wings not reaching to the tip of the tail; bill stout, orange, nail whitish; feet yellowish.

Gray-lag Goose, Latham. Oca paglielana, Stor. degli uccelli. v. pl. 559. Anas anser, L. Temm.

Inhabits the cold and temperate regions of eastern Europe and Asia: not uncommon during winter iu Italy : never observed wild in America : domesticated throughout the world.

2. Anser rufescens, Brehm. Dark cinereous, beneath whitish, strongly tinged with rusty; wings not reaching to the tip of the tail; bill short, stoutish, hardly depressed, black and orange.

Inhabits the Arctic regions: common in Iceland: strays accidentally to the north of Europe.

3. Anser medius, Temm. Dark cinereous, beneath whitish; rump blackish; wings when closed reaching to the tip of the tail ; bill and feet yellow. Length less than two feet.

Anser cineraceus? Brehm. Anser medius, Meyer. Never figured.

Inhabits the Arctic regions: migrating accidentally to the north of Europe. All these species are probably accidental visitants of the United States; we therefore mention them in notes. 
temperate regions : very rare and accidental in the United States.

320. Anser bernicla, Nob. Blackish-ash; head neck and breast, black; a white patch each side of the neck; beneath whitish ; bill and feet black ; tail of sixteen feathers.

The Brant, Anas bernicla, Wils. Am. Orn. viii. p. 131 . pl. 72. fig. 1. Anser torquatus, Frisch Vieill.

Inhabits the Arctic regions, migratory in both continents : very common and numerous in the middle states at its double passage, when great havoc is made among them.

\section{CYGNUS.}

Anas, L. Gm. Lath. Ill. Temm. Ranz. Anser, Briss. Cygnus, Bechst. Cuv. Vieill. Brelım Stephens Boie. Cygne, Temm.

BILL at base higher than broad, gibbous, subcylindric above, of equal breadth throughout, obtuse ; teeth lamelliform; upper mandible unguiculated and curved at tip; lower shorter, narrower, covered by the margins of the upper, flattened : nostrils medial, oval, open, pervious, covered by a membrane : tongue thick, fleshy, broad, fimbriated on the sides, obtuse. Head small, lora naked: neck exceedingly long, much longer than the body, slender; body much compressed, elegantly shaped. FEET placed far back, very short, stout, large; tarsus shorter than the middle toe ; middle toe longest, outer longer than the inner, webs full, entire, very broad; hind toe equal to a phalanx of the middle, simple, touching the ground merely at tip. Wings very long, when folded, the primaries hardly reach beyond the secondaries; first and fourth primaries equal; second and third longest. TaIL cuneiform, of numerous feathers.

Female somewhat smaller, perfectly similar to the male. Young differing from the adult for two or three years. Moult simple, annual, but protracted. Plumage excessively close 
and thick, very soft and light. Colors uniform. Size very large; largest of the Order.

Habits aquatic. Live on fiesh water, rivers or ponds: admirably built for swimming, surpassing all other birds in grace and elegance on the water: often in swimming spread out their wings as if sailing. Feed in the water, reaching to the bottom in shallow places, by means of their long neck : from their conformation and the lightness of their plumage, unable to sink their body. Food chiefly vegetable, also reptiles, especially frogs, and small aquatic animals, which they seek in the mud under water, hardly ever preying on fishes, which they even protect ; hence, and for their beauty and elegance, kept on fish ponds as ornaments. Strictly monogamous: unlike all other birds, copulate standing and facing each other in the water : build on ground in the vicinity of, or surrounded by water : nest composed of marsh plants in large quantity. Male protecting the female while sitting, and partaking the parental cares. When resting, place one foot on the back. Walk awkwardly. Flight very heavy; when elevated, rapid and protracted.

Inhabit all over the globe. Four species only, though others have been injudiciously added: one in North, one in South America, one in New Holland, and two in Europe, of which one is identical with the North American. Connects Anser with Anas, perhaps more closely allied to the latter.

321. Cygnus musicus, Bechst. White, top of the head yellowish; bill black, without protuberance; bare space round the eye yellow.

Young light cinereous, bare space round the eye fleshcolor.

Whistling Swan, Lath. Cigno salvatico, St. degli ucc. ii. pl. 554. Anas cygnus, L. Lath. Swan of Wilson's list. C. melanorhyncus, Meyer.

Inhabits the Arctic circle, whence it migrates in both continents : very numerous in winter in Chesapeake Bay; a rare 
and accidental visitant in Italy. Trachea forming two circurnvolutions before entering the sternum.*

\section{ANAS.}

Anas, L. Gm. Briss. Lath. Ill. Cuv. Vieill. Temm. Ranz. Anas, Brehm. Nob. Obs. and Cat. of birds of the U. S. Tadorna, Cairina, Anas, Rhynchaspis, Dafila, Mareca, Querquedula, Steph.

BiLl broader than high at base, more or less broader at tip than at base, somewhat flattened, much depressed towards the point, obtuse, marginal teeth lamelliform, weak; upper mandible convex, curved and unguiculated at tip, nail slender; lower narrower, flat, entirely covered by the margins of the upper : nostrils basal, approximated, oval, small, open, pervious, covered by a membrane: tongue fleshy, thick, broad, fimbriated on the sides, obtuse. Head small ; neck slender, subequal to the body : body much compressed, slender. Feet nearly central, rather small and feeble; tarsi sub-

* 2. Cygnus olor, Vieill. White ; bill red margined with black; bare space round the eye, and a fleshy knob on the forehead, black.

Young dark cinereous.

Mute Swan, Lath. Cigno reale, St. degh. ucc. v. pl. 554. Cygnus gibbus, Bechst. Anas olor, Gm.

Inhabits the eastern part of Europe, and Asia: never observed wild in America. Domesticated throughout the world. Trachea without circumvolutions.

3. Cygnus nigricollis, Steph. White, head and neck black, bill red.

Black-necked Swan, Lath. Anas nigricollis et melanocephala, Gm. Not figured. Scudder's Museum, New-York.

Inhabits South America: common at the Falkland Islands, and the Straits of Magellan.

4. Cygnus atratus, Steph. Black, quill feathers white, bill red.

Black Swan, Lath. Anas atrata, Lath. Anas plutonia, Shaw Nat. Misc. pl. 108. Philadelphia and New-York Museums.

Inhabits Australia. 
equal to the middle toe, not extremely compressed; tibia smooth; toes moderate, middle longest, inner shortest; webs full, entire, but not very large; hind toe equal to a phalanx of the middle, simple, touching the ground at tip. Wings moderate, acute; primaries elongated, first and second, or second only, longest. TaIL of from fourteen to twenty feathers.

Female very different from the male in full plumage. Young generally more or less resembling the female. Moult twice in the year, the female partially, the male completely, assuming in summer the humble dress of the female. Plumage thicker than in the Geese, but not so thick as in the Swans and Fuligula. A mirror or speculum on the wing in most species. Colors of the female dull, grayish. Trachea swelling at the bifurcation into cartilaginous capsules.

Migrate in large flocks : in autumn and winter keep in fresh water and rivers, affecting green shores and sedgy places, especially shallow water, where they can reach the bottom with their bill, without diving. Somewhat nocturnal: feed and travel by night. Food chiefly vegetable, plants and seeds, but also aquatic animals. Disposed to polygamy : build in the grass, more or less near water, some in hollow trees: nest lined with down: eggs numerous. Female alone incubates, without any assistance from the male, and covers the eggs with the lining of the nest and other materials when obliged to leave them. The male does not trouble himself about the young. Walk comparatively well, but not so well as the Geese, with the body poised, and the feet close together. While swimming raise the tail and stretch their body. Avoid deep water: dive only when compelled by necessity, or in the breeding season. Flight comparatively light, often high, whistling.

Spread all over the globe : species numerous, more so in temperate regions. We divide them into four subgenera, two only of which are found in the United States.

Vox. II. 
SUBGENUS I. RHYNCHASPIS.

Rhynchaspis, Leach. Steph.* Spatula, Boie. Les Souchets, Cuv.

Bill long, without fleshy protuberance; upper mandible semi-cylindric, broad and sub-orbicular at the end, nail small, much incurved; lamelliform teeth very long, fine and slender. Head wholly feathered.

Female differing greatly from the male.

Feed chiefly on small aquatic animals, which they obtain by sifting the mud between their teeth. Bill very sensible, as appears by the desiccation of the nervous apparatus.

322. Anas clypeata, L. Mirror green, margined above with white, below black; wing-coverts light bluish.

Male brown; head and neck green; belly chesnut.

Female and young wholly brownish, varied with yellowish and blackish.

Shoveller, Anas clypeata, Wils. Am. Orn. viii. p. 65. pl.6\%. fig. 7

Inhabits the north of both continents, extending its periodical migrations far to the south : not uncommon during winter throughout the United States and Mexico.

SUBGENUS II. ANAS.

Anas, Dafila, Mareca, Querquedula, Stept.

Bill moderate, subequal in breadth throughout, without fleshy protuberance; teeth small, comparatively coarse. Head wholly feathered.

* Stephens, however, in his genus Rhynchaspis, includes species belonging to our genus Fuligula, as well as to our Anas. According to his system they even belong to different stirpes, and the common character being one of analogy simply, he must form a new genus, for which names enough may be found. Spatula might be applied to the present, Rhynchaspis to the latter. 
Female very different from the male.

Feed on tender aquatic plants, chiefly seeds and grains, also on spawn, fry, and other aquatic animals.

323. Anas boschas, L. Mirror violet, bounded with black and white; rump blackish, tail of twenty feathers.

Male, head and neck green; a white collar; middle tailfeathers recurved.

Female and young wholly brownish, varied with yellowish and blackish.

The Mallard, Anas boschas, Wils. Am. Orn. viii. p. 112. pl. 70 . fig. $\%$.

Inhabits the north of both continents, advancing far to the south in its periodical journeys : common during winter throughout the United States where a few breed.

324. Anas strepera, L. Mirror white, bordered by black and chesnut; feet orange, webs blackish; tail of sixteen feathers.

Male blackish waved with white; rump black.

Female duller, rump uniform with the rest.

The Gadwall, Anas strepera, Wils, Am. Orn. viii. p. 120. pl. 71. fig. 1 .

Inhabits the north of both continents, whence it migrates in winter : rather rare in the United States.

325. Anas acuta, L. Mirror green, margined with black and white, above with rusty; tail very long, cuneiform, acute, of sixteen feathers; bill very long, linear, slate color.

Male light ash, a white stripe each side of the neck; two middle tail feathers greatly elongated, tapering; rent black.

Female dusky, speckled with white; speculum and vent uniform with the rest; middle tail feathers not elongated.

Pintail Dusk, Anas acuta, Wils. Am Orn. viii. p. 72. pl. 68. fig. 3.

Inhabits the north of both continents, migrating far to the 
south: very common in the United States and Italy during winter.

326. Anas americana, Gm. Mirror green, surrounded by black; wing-coverts white; tail cuneiform, of sixteen feathers. Male, black waved with reddish; head and neck yellowishwhite; crown cream color; a green band each side of the neck; breast vinaceous; throat whitish.

Female, dark brown, whole head and neck yellowishwhite, sprinkled with black.

American Widgeon, Anas americana, Wils. Am. Orn. viii. p. 86. pl. 69. fig. 4 .

Inhabits throughout North America and the West Indies: common during winter in the middle states, breeding to the north, Hudson's Bay, but not extending so far north as the preceding species. Closely allied to the European widgeon, Anas penelope, of the old continent.*

32\%. Anas obscura, Gm. Mirror violet blue, margined with black; under wing coverts pure white; tail of sixteen feathers.

Male and female, blackish brown mixed with paler; nearly alike, female only more brownish.

Dusky Duck, Anas obscura, Wils. Am. Orn. viii. p. 141. pl. 72. fig. 5 .

Inhabits throughout temperate America, where it breeds :

* Anas penelope, L. Mirror green, surrounded by black; wing-coverts white.

Male, black waved with white; head and neck reddish-chesnut; crown cream color, no green band; breast vinaceous; throat black.

Female, dark brown; whole head and neck reddish, sprinkled with black.

Wigeon, Whewer or Whim, Lath. Le Canard Siffleur, Buff.pl. enl. 825.

Inhabits the north of the old continent, not extending to the Arctic circle; common during winter in Italy; a few breed in temperate Europe, especially to the east. 
very common from Florida to Canada; not farther north; partially migrating, more numerous during winter in the middle and southern states.

328. Anas spons., L. Metallic, throat white; a pendent crest ; mirror purplish-blue, tipped with white; under wingcoverts white, spotted with black; tail of fourteen feathers. Bill small, tapering.

Male, head and crest golden green, with two white stripes; breast and sides of the rump, dark chesnut.

Female, head and crest brownish; a white space round the eye.

Summer Duck, or Wood Duck, Anas sponsa, Wils. Am. Orn. viii. p. 97. pl. 78. fig. 3 .

Inhabits throughout North America, Mexico, and the West Indies, not extending far to the north : common during summer in the northern and middle states, where it breeds : migratory : a few resident in the southern. Builds on trees.

329. Anas discons, L. Mirror green, bordered above with a single white band; wing coverts light-blue; quill shafts dusky; tail of fourteen feathers.

Male, head and neck purple-green; crown black; a white crescent each side of the head before the eye.

Female, head and neck wholly dusky.

Blue-winged Teal, Anas discors, Wils. Am. Orn. vii. p. 74 . pl.68. fig. 4 .

Inhabits throughout North America, Mexico, and the West Indies, breeding to the north, wintering to the south : common in the middle states at their double passage in spring and auturnn : very numerous during winter in the southern states : do not extend far north. Closely allied to Anas querquedula of the old world.*

* Anas querquedula, L. Mirror ashy-green, bordered with two white bands, one above, the other below ; wing-coverts bluish-ash : quill shafts pure white; tail of fourteen feathers. 
330. Anas crecca, L. Mirror rich green, black on the sides, margined with white and rufous ; wing coverts brownish-ash; tail of sixteen feathers.

Male, head and neck glossy chesnut; a green band each side of the head; throat black.

Female wholly dusky, skirted with whitish; throat white.

Green-winged Teal, Anas crecca, Wils. Am. Orn.viii.p. 101. pl. 70. fig. 4 .

Inhabits the north of both continents, migrating periodically far to the south : very common during winter throughout the United States and Italy.

\section{FULIGULA.}

Anas, L. Gm. Lath. Ill. Vieill. Ranz. Anas, Anser, Briss. Fuligula, Nob. Orn. Rom. (ined.) Nom. Wils. Orn. Cat. of birds U. S. Spechio Comp. Rom. Ph. (as a subgenus.) Platypus, Brehm. Hydrobates, Temm.* Harelda, Clangula, Fuligula, Oidemia, Biziura, Somateria, Khynchaspis, Steph.† Nyroca, Ania, \&c. of other Englishauthors.

Male, head and neck reddish-brown, sprinkled with white; crown blackish; a white line above the eye.

Female, wholly dusky, skirted with whitish; blue of the wings, and green of the mirror, obsolete.

Garganey, and Summer Teal, Lath. La Sarcelle d'Ete, Buffpl. enl. 946.

Inhabits the north of the old continent, not extending to the Arctic circle; common in temperate Europe, where it breeds.

* This name has been applied by Vieillot to the genus Cinclus of authors, and by Boie to Mr. Vigors' Thalassidroma, and is too closely resembling the Family name Hygrobatæ of Illiger, having precisely the same meaning and derivation. The name of Platypus is also preoccupied in Zoology, having been applied to a genus of minor animals. My name of Fuligula has, moreover, the priority, as a subgenus, over any other; and as we have since ascertained, has the advantage of having been used by Ray.

+ In this genus are placed birds with and without the hind toe membrane, and of more or less aquatic form and habits. 
Macreuses, Gurrots, Eiders, Millouins, Cuv. Clangula, Melanilta, Somateria, Aythya, Boie.

BiLc broader than high at base, not of equal breadth throughout, somewhat flattened, nuch depressed towards the point, obtuse; upper mandible convex, curved and unguiculated at tip, nail slender; lower narrower, flat : nostrils basal or medial, oval, open, pervious, covered by a membrane; tongue fleshy, thick, broad, fimbriated on the sides, obtuse. Head thick, wholly feathered; neck stout, much shorter than the body : body plumpish. FEeт placed very far back, large and stout; tibia partly covered by the skin of the belly, furnished before with an acute prominence; tarsi much shorter than the middle toe, extremely compressed; toes rather long, middle one longest; inner shorter than the outer; webs full, entire, very broad; hind toe equal to a phalanx of the middle one, furnished with a membrane, touching the ground at tip. Wings shortish; quills very stiff; first and second primaries subequal. TaIL stiff, of from twelve to eighteen feathers.

Female very different from the male. Male hardly changing from season. Young similar to the female, not assuming their adult dress before the second or third year. Moult twice a year without changing their colors. Plumage short, not so light, but closer and thicker than in the preceding genus. Capsule of the windpipe of the male much larger.

Migrate in large flocks. Found mostly in the north, affecting in autumn and winter, the sea shore and brackish water; fond of deep water, enjoying even the most boisterous sea. Swim and dive with great agility, and make long distances under water, diving for food or in sport. Somewhat nocturnal ; feed and travel by night. Food chiefly animal, especially mollusca, also a few vegetables, after which they dive. Strictly monogamous : build chiefly on fresh water: nest downy within: eggs numerous. Female only sits, and leads her young to the water as soon as hatched, after food. 
Hardly able to walk, standing with the body erect, the feet wide apart, and turned out: run rather rapidly, but awkwardly, appearing to fall at every step. Swim very deep in the water. Flight heavy, rapid, whistling.

Spread all over the globe ; chiefly Arctic. Species numerous. Deserve generic separation, as is proved by their form, habits, and especially their skeleton, the best test of genera. We divide the North American species into five subgenera.

SUBGENUS I. SOMATERIA.

Les Eiders, Cuv. Anser, Briss. Somateria, Leach. Boie. Steph.

Bill small, elevated at base, extending up the forehead, and divided by a triangular projection of feathers, towards the point narrow and blunt: nostrils medial. Secondaries generally curved outwards, overlapping the primaries. Tail of fourteen feathers.*

Plumage remarkably thick and close: down of an exquisite softness, valuable. Size large.

Exclusively pelagic: breeding near the sea: eggs comparatively few. Connects this genus with Anser.

'331. Fuligula moldissima, Nob. Branches of the bill narrow, linear : no mirror.

Male black, head and back white; crown black.

Female, wholly reddish-drab, spotted with black; two white bands across the wings.

* It is lamentable to find authors generally attribute twelve feathers to the tail of all the Geese, Ducks, \&c. We have made use of this character in our specific phrases, more to excite inquiry on that point than for any thing else, for we are well aware that the number is variable in some cases, and for that reason left out by authors : we think, however, that in most cases the character is excellent, and at all events, we have constantly given it as additional. 
Eider Duck, Anas mollissima, Wils. Am. Orn. viii. p. 122. pl. 72. fig. 2. male. and p. 125. pl. 71. fig. 2. female.

Inhabits the extreme north of both continents : an occasional winter visitant in the middle states, breeding sometimes in the most northern part of the union: very common in Iceland.

332. Furigura spectabilis, Nob. Branches of the bill broad, circular. No mirror.

Male black; head and back white, crown light ashy-blue ; an arrow-shaped black mark on the throat.

Female, reddish-drab spotted with black; a single white band across the wings.

King Duck, Lath. Gray-headed Duck, Edw. pl. i54. Anas spectabilis, $\boldsymbol{L}$.

Inhabits the extreme north of both continents : an accidental visitant during winter in the northern states: common in the northern British Islands.

SUBGENUS II. OIDEMIA.

Macreuses, Cuv. Melanilta, Boie. Oidemia, Fleming. Oidemia, Biziura, Leach. Oidemia, Biziura, Sieph.

Bill broad, gibbous above the nostrils; margins dilated, lamelliform teeth coarse. Nostrils sub-medial, large, elevated. Tail of fourteen feathers.

Colors black. Female brown.

Live chiefly near the edge of the surf.

333. Fuligula perspicilidata, Nob. No mirror; feet red; bill with a prominence each side.

Male glossy black; crown and hind neck marked with white.

Female wholly sooty-brown, near the bill and auriculars, whitish.

Black, or Surf Duck, Wils. Am.Orn. viii. p. 49. pl. 67. fig. 2 .

Inhabits the Arctic regions of America, whence it migrates periodically in great numbers, all along the coasts of the

VoL. II. 
union : very common throughout the winter, from Canada to Florida: an accidental visitor in north-western Europe.

334. Fuligula nigra, Nob. No mirror; feet dusky; bill protuberant at base; tail cumeiform.

Male glossy black; a large red knob at the base of the bill. Female sooty-brown, beneath grayish-white.

Scoter Duck, Anas nigra, Wils. Am. Orn. viii. p. 135. pl. 72. fig. 2.

Inhabits the north of both continents, whence it migrates in winter to temperate climates: very rare in the middle states as well as in Italy : very common in northern Asia and eastern Europe.

335. Fultaula fusca, Nob. Mirror white; feet red.

Male black, a white spot under the eye.

Female blackish-brown.

Velvet Duck, Anas fusca, Wils. Am. Orn. viii. $p .13 \%$ Inhabits the north of both continents, migrating during winter to temperate climates: not uncommon in the middle states; rare in Italy : very common in Siberia.

SUBGENUS III. OXYURA.

Rhynchaspis, Oidemia, Steph. Macreuses, Cuv.

Bill broad at tip, nail very small. Wings very short, concave. Tail long, cuneiform, of eighteen narrow pointed, rigid, canaliculate feathers.

Plumage remarkably thick, compact, and beneath silvery.

336. Fuligula rubida, Nob. No mirror; bill plane at base; nostrils small, linear; tail-feathers canaliculated at tip only.

Male reddish-brown; crown and neck above, black; cheeks and throat white.

Female blackish, finely mixed with whitish ; crown blackish ; sides of the head and throat whitish.

Ruddy Duck, Anas rubida, Wils. Am. Orn. viii. p. 13\%. pl. 71. fig. 5. male. p. 130. fig. 6. young male. 'emale Wils. 
Inhabits throughout North America, breeding in the north, wintering in the south: not uncommon during spring and autumn in the middle states. Closely allied to F. leucocephala, of the old continent, and apparently also to $\mathbf{A}$. jamaicensis, Lath. with which it is perhaps identical.*

\section{SUBGENUS IV. FULIGULA.}

Les Millouins, Cuv. Fuligula, Leach. Steph. Nyroca, Flem. Aythya, Boie.

Bill long, broad, flat, hardly gibbous at base, somewhat dilated at the end. Nostrils basal, suboval. Tail short, of fourteen feathers.

Trachea dilating to the left into a partly membranous capsule, sustained by an osseous frame, and osseous ramifications.

337. Fuligula labradora Nob. Mirror broadly white; bill soft and membranous at tip, orange and cerelike at base.

Male black; head, neck, breast, scapulars, wing-coverts and secondaries, white; crown, and a collar round the neck, black.

Female ashy-gray.

Pied Duck, Anas labradora, Wils. Am. Orn. viii.p. 91. pl. 69. fig. 6. male.

Inhabits the north of America, where it breeds, not extend-

* Fuligula leucocephala, Nob. No mirror; bill gibbous and with two ridges, with a channel between, at base ; nostrils large, subrounded, projecting; tail-feathers canaliculated throughout.

Male reddish-brown; top of the head and neck above, black; front, nape, cheeks and throat, white.

Female finely mixed with blackish, whitish, and rusty; crown wholly blackish; sides of the head and throat white.

White-headed Duck, Lath. Anatra d'inverno, St. degli Ucc. v. pl. $55 \%$. male. Anas mersa et leucocephala, Gm.

Inhabits northern Asia and eastern Europe : an accidental winter visitant in Italy, and even the northern coasts of Africa. 
ing to the Arctic circle : very rare during winter in the middle states.

338. Fuligula vallisneria, Steph. Mirror gray; bill straight, more than two and a half inches long, sides parallel.

Male white, waved with black; head tinged with black anteriorly, and with the neck glossy chesnut; a black pectoral belt.

Female dull whitish, waved with black; head, neck and breast, brownish.

Canvas-backed Duck, Anas valisneria, Wils. Am. Orn. viii. p. 103. pl. 70. fig. 5 .

Inhabits North America, not extending to the Arctic circle: common during winter in the middle states: breeds to the north. Flesh exquisite, and in high repute, while feeding on certain vegetables, in peculiar districts.

339. Fuligula ferina, Steph. Mirror gray ; bill rather recurved, little more than two inches long, dilated at tip.

Male ash, thickly waved with black lines; head and anterior part of the neck only, wholly chesnut; a broad black pectoral belt.

Female wholly brown of various tints.

Red-headed Duck, Anas ferina, Wils. Am. Orn. viii. p. 110. pl. '70. fig. 6 .

Inhabits the north of both continents, spreading widely in its hybernal migrations : common during winter in the middle states, and also in Italy.

340. Fuligula marila, Steph. Mirror white; bill very broad; no crest.

Male glossy black, scapulars waved with white.

Female brown, near the bill whitish.

Scaup Duck, Anas marila, Wils. Am. Orn. viii. p. 84 . pl. 69. fig. 8 .

Inhabits the north of both continents, whence it migrates in winter to temperate climates: very common throughout 
the winter in the middle states : very numerous in several parts of Europe.

341. Fultaula rufitorques, Nob. Mirror bluish-ash; chin white; a bluish-white band across the bill ; no crest.

Male black, belly white, sides waved with gray; a chesnut collar.

Female glossy brownish, face and belly white.

Tufted Duck, Anas fuligula, Wils. Am. Orn. viii. p. 60. pl. 6\%. fig. 5. Anas rufitorques, Nob.

Inhabits North America, where it is widely spread: not uncommon in autumn and early spring in the middle states. Resembling Fuligula cristata, of the old continent.*

SUBGENUS V. CLANGULA.

Garrots, Cuv. Clangula, Boie. Clangula, Harelda, Leach."Steph.

Bill short, narrow, elevated, somewhat attenuated at the end. Nostrils basal, suboval. Tail long, mostly of sixteen feathers.

Live in extreme northern latitudes.

342. Fuligula clangula, Nob. Mirror white; under wingcoverts black; tail rounded, of sixteen rounded feathers.

Male white; back wings and tail black, head tumid, purplish-green, a white spot each side of the head.

* Fuligula cristata, Steph. Mirror white; bill much wider at tip than at base; crested.

Male glossy black, belly white; head with a large flowing crest.

Female similar to the male, colors brownish-black; crest shorter.

Young destitute of the crest, brown tinged with rusty; round the eyes whitish.

Anas fuligula, et scandiaca, Gm. Anas cristata, Ray. Tufted Duck, Lath. Le Morillon, Buff. pl. enl. 1001. adult male.

Inhabits the Arctic regions of the old continent, whence it spreads widely in Europe, Asia, and the north of Africa : never found as yet in America, which is extraordinary for an Arctic bird. 
Female cinereous, beneath white; head wholly drab.

Golden eye, Anas clangula, Wils. Am. Orn. viii. p. 62. pl. $6 \%$ fig. 6 .

Inhabits the north of both continents, extending far south in its migrations: common during winter in the middle states, and in Italy.

343. Fuligula albeola, Nob. Mirror white; under wingcoverts white; tail rounded, of sixteen rounded feathers.

Male varied with black and white; head tumid, purplishgreen; a large white space on the top of the head from each eye.

Female wholly sooty black, a white spot each side of the head.

Buffel-headed Duck, Anas albeola, Wils. Am. Orn. viii. p. 51.pl. 67. fig. 2. male. fig. 3. female.

Inhabits North America, not extending to the Arctic circle: very common during winter throughout the union; breeding to the north.

344. Fuligula stelleri, Nob. Mirror metallic black, margined with white; bill blackish-green; tail cuneiform, of twelve feathers.

Male white, beneath rusty ; forehead and band on the hind head greenish ; orbits, throat, collar, and back black.

Female reddish-brown, skirted with ash.

Western Duck, Lath. Anas dispar and Stelleri, Gm. Platypus Stelleri, Brehm. Steller's And, Swensk, Zool. ii. fasc. ii.pl.62. Omitted in my catalogue.

Inhabits the western coast of North America, and the opposite shores of Kamtschatka; very common at Oonalashka: strays accidentally in northern and eastern Europe, and most probably also in Atlantic America. Allied to the subgenus Oidemia.

345. Fuligula histrionica, Nob. Mirror blue-black; space 
before the eye and auriculars, white ; tail cuneiform of fourteen pointed feathers; bill very slender, nail curved.

Male bluish-slate, varied with black and white; eyebrows and flanks rufous.

Female uniform slatish-brown, belly whitish.

Harlequin Duck, Anas histrionica, Wils. Am. Orn. viii. pl. 139. pl. 72. fig. 4 .

Inhabits the Arctic regions of both continents, extending but little to temperate countries: rare and accidental during winter in the middle states.

346. Fuligula glaciails, Nob. Mirror brown, subuniform with the wing; a whitish space around the eye; tail cuneiform, of fourteen pointed feathers.

Male varied with black and white; middle tail feathers greatly elongated.

Female sooty brown, beneath white; crown blackish.

Long-tailed Duck, Anas glacialis, Wils. Am. Orn. viii. p. 93. pl. 70. fig. 1. male. p. 96. pl. 70 fig. 2. female.

Inhabits the Arctic regions of both continents, whence it migrates periodically in winter : very common all along the coasts of the union: found in temperate Europe, but rare and accidental.

\section{\%5. MERGUS.}

Mergus, L. Gm. Lath. Ill. Cuv. Temm. Vieill. Ranz. Merganser, Briss. Mergus, Merganser, Steph.

Bruc moderate, straight, somewhat cylindrical, depressed and broader than high at base, narrow, subulate, and somewhat compressed at the point ; edges serrated, teeth inclined backward, subulate, acute; upper mandible hooked and unguiculated at tip ; lower shorter, narrower, quite straight, obtuse : nostrils submedial, lateral, longitudinal, very small, elliptic, open, pervious, covered by a membrane: tongue thick, fleshy, almost subulate, furnished above with hard, recurved papillæ. HEaD moderate, somewhat compressed; neck well propor- 
tioned; body large, hardly compressed. FeEt placed far back, turned outward, robust; tibia much drawn up into the belly; tarsus one third shorter than the middle toe, much compressed; outer toe longest; inner shortest; webs full, entire ; hind toe equal to a phalanx of the middle one, touching the ground only at tip, furnished with a broad membrane: nails falculate. Wings moderate, very acute; quills stiff; first and second primaries subequal, longest. TAIL short, rounded, of from sixteen to twenty feathers.

Female and young difiering greatly from the adult male. Moult annually, the adult male in spring, the female and young in autumn? Plumage extremely thick and compact. Trachea of the male with two large expansions.

Wild: untameable. Live on waters. Migrate according to season, from cold to temperate countries. Keep in flocks, the adult males generally by themselves, leaving the young with the females. Extremely voracious : great destroyers of fish. Feed almost exclusively on fishes, of which they swallow surprising large ones, also on reptiles and insects. Build among grass near fresh water, rarely on bushes, or in hollow trees; nest lined with down; eggs from eight to fourteen. The male keeps near the nest while the female alone incubates : young led to the water after food as soon as hatched, by the mother only, the father showing great unconcern. Swim deep in the water, the body submerged, the head only out: dive by plunging, very deeply, and keep under water as long as they can go without breathing; reappearing at great distances, moving with great speed under the surface. Walk very awkwardly, in an erect posture. Fly very well, rapidly, and for a long time. Flesh tough, bad tasted.

Inhabit Arctic regions whence they migrate periodically. Formed of but five species, wantonly multiplied: all the European, and one besides, found in North America, the other is South American. Connects its own Family with that of the Pygopodes, which it resembles closely in habits. 
347. Mergus merganser, L. Mirror white uninterrupted; bill and feet red; nostrils medial.

Male black, neck and beneath white ; head tufted, purplishgreen.

Female cinereous, beneath white; head rufous.

Goosander, Mergus merganser, Wils. Am. Orn. viii. p. 68. pl. 68. fig. 2. female.

Inhabits the north of both continents, whence it spreads far to the south during winter: not uncommon all along the coasts and river's of the union, as well as in several parts of Europe.

348. Mergus Serrator, L. Mirror white, crossed with black; bill and feet red; nostrils basal; a long slender pendent crest.

Male black, neck and beneath white; head and crest purplish-green.

Female cinereous, head rufous.

Red-breasted Merganser, Mergus serrator, Wils. Am. Orn. viii. p. 91. pl. 69. fig. 2. male.

Inhabits the north of both continents, visiting during winter the temperate climes of North America and Europe : common in spring and autumn in the middle states.

349. Mergus cuculcatus, L. Mirror white, crossed with black; bill blackish-red; feet flesh color; a large circular crest.

Male black, beneath white; crest black, white on each side.

Female sooty brown, beneath white; crest wholly rustycinereous.

Hooded Merganser, Mergus cucullatus, Wils. Am. Orn. viii. p. 79. pl. 69. fig. 1. male.

Inhabits North America, breeding in the north, wintering in the south : common in spring and autumn in the middle states.

350. Mergus albellus, L. Mirror black, crossed with white: bill and feet bluish.

VoL. II. 
Male white, varied with black; crown white.

Female cinereous, beneath white; crown reddish-browno

Smew, or White Nun, Mergus albellus, Wils. Am. Orr viii. p. 126. pl. 71. fig. 4. male.

Inhabits the north of both continents : very rare in the middle states : common in the northern, and in most parts of Europe.

\section{FAMILY XXVI. STEGANOPODES。}

Steganopodes, Lobipedes, Ill. Pinnipedes, Dumeril. Totipalmes, Cuv. Syndactyli, Urinatores, Vieill. Pelecanidi, Goldfuss. Pelecani, Oken, Boie. Cryptorini, Blainville. Unodactyli, Latr. Steganopodi, Podoa,Ranz. Pelecanida, Rallida, Vigors. Steganopodes, Lobipedes, Nob. Vicw of the Families. (23.)

Bilu longer than the head: nostrils linear, often inconspicuous : tongue very short. Skin of the throat generally naked, dilatable. FeEt nearly central, short, robust, 4-toed; tibia half, or entirely feathered; (in one genus tarsus also half feathered;) a great portion of the tibia drawn up into the belly; toes long, all four connected by a broad membrane, in one genus only, deeply scalloped; hind toe articulated with the tarsus internally, almost on a level with the others, directed forward: nails robust, curved, acute. Wings long; one of the first two primaries longest. TAL of twelve, fourteen, or twenty feathers.

Female smaller, similar to the male. Young difering greatly from the adult, and changing repeatedly. Moult once or twice in the year, scarcely changing the colors of their plumage.

Walk awkwardly. Rest on the branches of trees, which, as well as other objects, they are capable of grasping, thougl they may be styled web-footed by eminence. Dive with great agility, several also under water: the long-winged 
species hardly ever walk or swim. Excel in flight, some speeies flying continually day and night for several days, without resting. Feed chiefly on fishes : voracious: great consumers. Breed on trees or rocks, very few on the ground: eggs few : both sexes incubate, nurse, and feed by regurgitation, the young, which only leave the nest when full-fledged. Flesh black, cily, bad tasted. Some species may be trained to fish for man.

Traced in all latitudes and longitudes. More closely related to the Longipennes, than to any other Family : ought not to be separated from them by the Lamellosodentati, nor ought they to separate these fiom the Pygopodes.

A. Bill seamed above.

76. PELECANUS.

Pelecanus, L. Gm. Lath. Ill. Cuv. Temm. Vieill. Ranz. Onocrotalus, Briss. Scopoli.

Bilc very long, broad, stout, straight, much depressed; upper mandible convex at base, then plane, seamed on each side, ridge distinct, ending in a compressed, robust, and strongly hooked nail; lower broader, formed of two flexible cartilaginous branches united at tip, supporting a naked membrane, capable of forming by distention a pouch of great size, extending beyond the throat; edges of the upper mandible plane interually, separated from the palate by two longitudinal, approximated, sharp processes, palate carinated; lower edges sharp: nostrils in the furrow, basal, linear, longitudinal, hardly distinguishable : tongue cartilaginous, very small, obtuse and arcuated at tip. Head moderate, face and cheeks naked; eyes rather large; neck long, stoutish : body massive. FEET nearly central, short, robust; tibia naked below; tarsi shorter than the second toe, stout, naked; middle toe longest, one third longer than the outer; hind toe shortest, hardly half as long as the middle one; connecting 
membrane broad, full, entire : nails falculate ; the middle one with its edge entire or pectinated. Wings moderate, ample; second primary longest; secondaries reaching to the primaries. TaIL rounded, of twenty feathers.

Female similar to the male. Young differing greatly from the adult for a long period. Moult annually. Plumage short, very thick and close. Colors white or cinereous. Size exceedingly large; largest of the Family.

Live near w ater, either fresh or salt. Fly for long periods, reaching the highest regions of the atmosphere. Swim and dive admirably. Alight on the branches of trees, grasping firmly. Feed on fishes, which they catch with great adroitness, and keep in their gular pouch, emptying it by degrees as the digestion proceeds. Exceedingly voracious: consuming at a single meal more than six men. Rise sometimes to a great height, sometimes skimming the surface of the water, or balancing at a moderate elevation, and pouncing headlong with a loud noise and great agitation of the water: fishing in the morning and evening until their large bag is quite full, then retiring to a large rock or tree, to eat and digest at ease : when wishing to disgorge a fish, press their bag against their breast, hence fabulously said to feed their young by tearing their own body. Often uniting in great numbers to chase more successfully, encircling and beating a large piece of water, employing different stratagems to frighten the fish into a restricted space, where they seize them. Breed on rocks near water, nest flat on the ground, deep, lined with soft weeds: eggs from two to four. Affectionate parents. Sight keen, discerning their prey from a great elevation. Voice hoarse, powerful.

Spread all over the warm and temperate regions of the globe, even one of the species. Formed of five species.

351. Pelecanus onocrotalus, L. Middle nail entire; primaries black; first much longer than the fifth.

Adult white tinged with rose color; a slender crest. 
Young whitish-gray; back and wings dark cinereous.

The Pelican, Edw. Glean. pl. 92. adult. Le Pelican, Buff. pl. enl. 8\%. adult. Le Pelican des Philippines, Buff.pl. enl. 965. young. P. onocrotalus, roseus, manillensis, philippensis, auct.

Inhabits throughout the world: rare and accidental on the coasts of the middle states.

352. Pelecanus fuscus, L. Middle nail serrated internally : primaries black, shafts white; first equal to the fifth.

Adult blackish-ash, back and wings hoary; crown yellowish; neck deep chesnut, margined each side with white.

Young wholly brownish.

Brown Pelican, Pelecanus fuscus, Nob. Am. Orn. v. pl. P.fuscus, Vieill. Gal. des Oiseaux pl. 276. Pelican brun d'Amerique, Buff. pl. enl. 95\%. P. fuscus, carolinensis, trachyrhyncos or erythrorhyncos, auct.

Inhabits the southern states, the West Indies, Mexico, and South America : common in the southern states, where it breeds.

\section{PHALACROCORAX.}

Pelecanus, L. Gm. Lath. Phalacrocorax, Briss. Cuv. Dumeril. Dumont. Ranz. Halieus, 1ll. Oken. Carbo, Lacep. Meyer. Temm. Brehm. Hydrocorax, Vieill.

Bill moderate, robust, thick, straight, compressed; upper mandible seamed and rounded above, with the ridge distinct, unguiculated and hooked at the point, rather obtuse; lower somewhat shorter, truncated at tip, osseous throughout, furnished at base with a small naked coriaceous membrane produced on the throat : nostrils in the furrows, basal, lateral, linear, hardly visible: tongue cartilaginous, very short, carinated above, papillous beneath, obtuse. Hind head very protuberant; face and small pouch naked; neck rather short, of moderate strength : body compressed. FEeT short, robust, 
somewhat turned outward; tibia much drawn up into the belly, wholly feathered; tarsus naked, one third shorter than the outer toe, inuch compressed, carinated before and behind; outer toe longest, edged externally by a sinall membrane; connecting membrane broad, full, entire; hind toe half as long as the middle : nails moderate, curved, broad, bluntish; middle nail serrated on the inner edge, equal to the others. Wings moderate, slender; quills stiff; second and third primaries longest. TAIL rounded, of twelve or fourteen rigid feathers.

Female similar to the male. Young, especially yearling, differing greatly from the adult. Moult twice in the year, acquiring additional ornaments in winter. Plumage very thick and close. Colors black.

Keep in families near water. Fly well and rapidly. Alight on branches, or sit for hours on high rocks, with their wings spread open. Walk in an erect posture, awkwardly, resting on their rigid tail. Swim admirably, deep in the water, generally their head only appearing. Dive after their prey: remain long, and advance rapidly under water, pursuing their prey with the aid of their wings. Feed almost exclusively on fishes. Retire from the water with their prey in their bill; in order to swallow it head foremost, toss it up in the air, catching it as it falls. Build on high trees or rocks, or even on the ground among reeds : nest made with little art, and of coarse materials; eggs three or four, whitish. May be trained to fish for mall.

Spread all over the world. Species rather numerous, about fiftcen.

353. Phalacrocorax carbo, Dumont. Bill four inches long; tail moderate, rounded, of fourteen feathers.

Adult glossy black; a white collar on the throat; in winter, a golden green crest; head, neck and thighs with long, slender, silky, white feathers.

Young blackish, beneath mixed with whitish. 
Pelecanus carbo, L. Carbo cormoranus, Temm. Le Cormoran, Buff. pl. enl. 927. adult in full dress. Corvorant of Wilson's list.

Inhabits the north of both continents : rare and migratory in the United States.

354. Pralacrocorax graculus, Dumont. Bill three and a half inches long; tail very long, conic, of twelve feathers.

Adult greenish-black; a few scattered white streaks on the neck; in winter bronzed, a golden-green crest; head, neck and thighs, with short small white feathers.

Young blackish, more or less mixed with whitish beneath.

Pelecanus graculus, L. Carbo graculus, Temm. Fou brun de Cayenne, Buff.pl.enl.974. young. Pelecanus parvus, Gm. Lath. young.

Inhabits both continents and both hemispheres: not uncommon in spring and autumn in the middle states : very common in Florida, where it breeds! though very abundant in the Arctic and Antarctic circles.

355. Phalacrocorax cristatus, Dumont. Bill very slender, three and a half inches long; tail very short, rounded, of twelve feathers.

Adult bright golden-green, without white feathers : in winter a broad, long, golden tuft on the top of the head, and a slender crest behind.

Young blackish, beneath more or less whitish.

Crested Shag, Lath. Pelecanus cristatus, Gm. Carbo cristatus, Temm. pl. col. 322. adult in full dress. Carbo brachyurus, Brehm.

Inhabits the north of both continents : rather rare, and during winter only, in the United States.

356. Phalacrocorax pygmeus, Dumont. Bill one inch and a half long, shorter than the head; tail long, cuneiform, of twelve feathers: scapulars long, subulate.

Adult black, slightly glossed with green; eyebrows dotted 
with white; orbits and pouch black : even in winter no crest, head, neck and thighs, finely streaked with white.

Young blackish, beneath whitish; orbits and pouch yellowish.

Dwarf Shag, Lath. Pelecanus pygmaus, Pallas, Reise. ii. p. 712.pl. G. Carbo pygmeus, Temm.

Inhabits the north of both continents? common in northern Asia, and eastern Europe.

357. Phalacrocorax africanus, Dumont. Bill two inches ong, longer than the head; tail long, rounded, of twelve feathers; scapulars long, subulate; size very small.

Adult black, slightly glossed with green; throat white.

Young blackish, beneath whitish.

African Shag. Pelecanus africanus, Gm. Lath. Not in my Catalogue.

Inhabits both continents :* not found in Europe.

78. TACHYPETES.

Pelecanus, L. Gm. Lath. Scopoli. Sula, Briss. Fregata, Lacep. Cuv. Dumeril. Halieus, Ill. Oken. Tachypetes, Vieill. Temm. Ranz.

BiLc longer than the head, robust, dilated and entire on the margins; both mandibles strongly hooked and acuminate at the point; upper unguiculated, very acute, depressed at

* We are somewhat doubtful, whether this and the preceding species are entitled to a place in this Synopsis, particularly P. pygmæus, of which we have seen but one specimen said to be American, and there is reason to doubt, whether that was really killed in the United States. We have less reason for suspecting the nativity of $P$. africanus, having seen several reported American, specimens. At all events, in such a case as this, as it is not introducing a nominal species, we have preferred abundance to deficiency. A species of this genus which we are not prepared to exemplify, perhaps the P. brasilianus, inhabits the United States. 
base, ridge deeply grooved each side, edges dilated, sharp, entire: nostrils in the furrows, basal, linear, obsolete: tongue very short, lanceolate: gape very wide: orbits and lores naked : throat dilatable, pouch large. Head moderate; eyes large: neck moderate: body compressed, elongated. FEET very short, drawn up into the belly; tibiæ wholly feathered; tarsus one third shorter than the outer toe, much compressed, carinated before and behind, half feathered; toes long, semipalmated, the connecting membrane being deeply indented; second much the longest; outer longer, but subequal to the inner, edged exteriorly by a small membrane; hind toe half as long as the middle; nails large, curved, acute: middle serrated on the inner edge, twice as large as the others. WINGS extremely long, very narrow; first primary longest, the others decreasing successively very much. TaIL deeply forked, of twelve flaccid feathers.

Female similar to the male. Young differing from the adult, and changing repeatedly. Moult twice a year, changing somewhat in color. Plumage not water proof. Colors black.

Tyrants of the ocean. Associate in small flocks. Keep constantly on the wing, flying swiftly against the strongest gales, and rising above the clouds. Easily distinguished at a distance. Traversing rapidly vast spaces, and appearing farthest at sea, though hardly able to rest on the water on account of the nature of their plumage. Never dive nor swim. Resting only on trees, or on high rocks : unable to rise, and easily caught when on the ground. Following large voracious fishes in pursuit of small ones, in order to catch the latter as they leap out of water, often seizing the pursuer himself. Prey also on the Pelicans, but especially on the Gulls and Boobies, which they compel, always keeping above them, to drop the fruits of their industry, or even to disgorge what they had swallowed, seizing it before it reaches the water. Flight very rapid. Sight very keen. VoL. II. 
Pouncing from the sky on flying fishes, and never missing in the air; unable to fish in water, from which they could not rise again; skim the surface, or lie suspended with their wings raised over their back. Breed on trees on desert shores, or on elevated rocks: eggs one or two.

Chiefly tropical. Formed of but two species, of which one is even doubtful. Analogous in form and habits to the Accipitres, especially the Eagles, which they replace on the sea.*

358. Tachypetes aquilus, Vieill. Purplish-black: orbits black; shaft of the outer tail feather white beneath.

Adult, summer plumage? head white.

Young, part of the breast and belly white.

Frigate, Tachypetes aquilus, Nob. Am. Orn. v. Grande Fregate de Cayenne, Buff.pl. enl.961. Pelecanus, aquilus, leucocephalus, et palmerstoni, Gm. Lath. Tachypetes aquila, Vieill. Gal. des Ois. pl. 274.

Inhabits the tropical seas, spreading somewhat in each temperate zone: not uncommon during summer on the coasts of the United States, as far north as South Carolina. The changes of plumage in this species, are not yet well known.

79. SULÅ.

Sula, Briss. Cuv. Temm. Ranz. Pelecanus, L. Gm. Lath. Dysporus, Ill. Morus, (since Sula) Vieill.

Birs longer than the head, cleft beyond the eyes, robust, straight, conic-elongated, very stout at base, compressed, mandibles subequal; upper seamed each side, ridge distinct,

* This analogy, observed by Linnè, as is evident from his specific name, has lately been mistaken for affinity. 
rounded, slightly curved at the point, edges obliquely serrated : nostrils in the furrows, basal, linear, much elongated, hardly distinguishable : tongue very short, oval : gape wide. Head rather small; eyes rather large; lores and orbits naked, pouch small; neck rather short and robust; body rather large. FEET short, robust, drawn up into the belly; tarsi naked, one third shorter than the outer toe, rounded before, carinated behind; outer toe somewhat longest, bordered exteriorly by a small membrane; hind toe one third the length of the outer; connecting membrane broad, full entire ; nails moderate, curved, rather acute; middle serrated on its inner edge; hind nail merely rudimental, rounded, not projecting beyond the toe. Wings long, acute, tuberculated; first and second primaries longest. TaIL cuneiform, of twelve rigid feathers.

Fenrale similar to the male, smaller. Young very different from the adult, and changing repeatedly for several years, even increasing in size. Moult annually. Plumage thick and close. Colors white or dusky.

Cowardly and stupid to excess : though strong and well armed, neither resist or try to escape danger : suffer themselves to be taken or killed, and permit the Frigate or Lestris, to deprive them of their prey, disgorging when hard pushed what they have swallowed. Live on rocks near the sea, constantly flying about, usually not far from the shore, though not certain indications of land. Fly with the neck stretched out, and the tail spread. Hardly ever swim, never dive. Walk awkwardly, standing erect, and supported by their rigid tail : cannot take a start from the ground, hence alight on elevated points. Fish by hovering with still, expanded wings, falling on their prey while at the surface of the water. Resort in great numbers to desert islands, where they breed in society. Build on trees, rocks, or even on the ground; eggs one, or two at most. Young for a long time covered with very soft, pure, white down. 
Spread all over the warm and temperate regions of the globe, some species even; others migrating in summer very far north. Species extremely few : two in the United States. Closely related in form and habits to the Family Longipennes, especially to the larger, stout-billed Sternæ. Connecting the Longipennes and Steganopodes.

359. Sula bassana, Lacep. White, crown yellowish; quillfeathers black; shafts inferiorly white; face bluish.

Young blackish brown, spotted with white, beneath brownish-cinereous.

Gannet of Wilson's list. Pelecanus bassanus, L. Pelecanus maculatus, Gm. young. Sula alba, Temm. Le Fou de Bassan, Buff. pl. enl. 278. ad. Ie fou tacheté de Cayenne, Buff.pl. enl. 986. young.

Inhabits both continents: common during summer on the coasts of the United States, especially the southern.

360. Sula Fusca, Briss. Blackish-brown, beneath white; primaries black; face red.

Young spotted with white and brown.

Booby, Catesby Car. i.pl. 87. Sula fusca, Vieill. Gal. des Ois. pl. 277. Pelecanus sula, L. Buff.pl. enl. 973. Sula, et Sula fusca, Briss. Omitted in my Catalogue.

Inhabits sea coasts throughout the warm parts of the globe: common in summer on the coasts of the southern states.

B. Upper mandible of one piece.

80. PHAETON.

Phaton, L. Gm. Lath. Ill. Cuv. Temm. Vieill. Ranz。 Lepturus, Briss.

BiLL as long as the head, stout, somewhat robust, hard, much compressed, convex above, straight and acute at tip; mandibles equal; upper slightly curved towards the point, margins dilated and sharp at base, then compressed, and finely serrated obliquely: nostrils basal, lateral, longitudinal, 
concave, narrow, pervious, half closed by a membrane: tongue very short. Head and throat wholly feathered, the former depressed, moderate; eyes rather large; neck short, thick; body moderate, rather plump. FEET very short ; tarsi naked, shorter than the second toe: exterior elongated, middle longest; outer edged exteriorly by a small membrane; hind toe one third the length of the middle one : connecting membrane broad, full, entire : nails moderately curved, acute; middle with the inner edge entire. Wings long, tuberculated; first primary longest. T TIL short, of twelve or fourteen feathers; middle one very narrow, much elongated.

Female similar in color to the male, but much smaller. Young differ greatly from the adult, changing repeatedly. Moult twice a year. Plumage thick and close. Colors white.

Keep in families, chiefly in remote aud desert islands, appearing at wonderful distances from the land. Excel in flight, able to rest for a long time, and even sleep on the water. Never dive, even partially. Hardly able to walk, alighting on trees, or rocks, occasionally on the rigging of vessels. Feed chiefly on the flying fishes abounding between the tropics : seize them by skimming the surface of the water. Build in hollow trees, or on inaccessible cliffs : eggs two : young at first covered with very fine soft white down. Sight keen. Remarkable in their appearance: sure indications of the torrid zone, not, however, of the proximity of land.

Tropical, spread all around the globe. Composed of but three species, multiplied, owing to their changes. Related to the Family Longipennes, especially the genus Sterna.

361. Phaeton ethereus, $L$. White varied with black; bill red; tail cuneiform, of fourteen feathers.

Adult somewhat tinged with rose; long tail feathers red.

Tropic bird of Wilson's list. Buff. pl. enl. 979. ad. 1d. 998. young. Phaeton phenicurus, Vieill. Gal. des Ois. pl.279.ad. 
Inhabits the tropical seas : common during summer on the coasts of the southern states.

\section{PLOTUS.}

Plotus, L. Gm. Lath. Ill. Cuv. Vieill. Temm. Ranz. Anhinga, Briss. Forster. Ptinx, Moehring. Merganser, Barrere Klein.

Bilu longer than the head, very slender, straight, conicelongated, acuminate, much compressed, very acute, mandibles equal; edges finely serrated obliquely at the point; upper mandible perfectly straight throughout, margins dilated at base, compressed and bent in towards the point; lower hardly shorter, somewhat obtusely angular beneath : nostrils in a slight obliterated furrow, basal, longitudinal, linear, scarcely apparent : tongue very short, involved in the membrane of the mouth. Head small, elongated, cylindrical; face and throat naked; eyes moderate : neck very long and slender, bent in the middle: body massive. FEex short, stout, drawn up into the belly; tarsus half shorter than the middle toe, robust, naked; outer toe somewhat longest; hind toe half as long as the outer: connecting membrane broad, full, entire : nails robust, curved, very acute, the middle pectinated on the inner edge. WINGs moderate, tuberculated; first primary equal to the fourth; second and third longest. TaIL long, spreading, of twelve feathers; feathers broad, rounded, rigid, deeply striated, and appearing figured.

Female similar to the male. Young differing much from the adult, and changing repeatedly. Moult twice in the year, acquiring additional ornamental feathers in the spring. Plumage very soft, close, and downy. Colors black.

Exceedingly aquatic. Extremely shy and vigilant. Live in families, keeping in fresh water, far from the sea. Never walk nor remain on the wing, resting only on trees, whence they plunge directly into their favorite element: swim very deep, their head only appearing above water, and even that 
is withdrawn at the least appearance of danger. Neck kept constantly vibrating, in flight stretched forward. When alarmed, drop from the limbs where they sit in company, silently sliding into the water, re-appearing at a distance, their slender neck and small head being easily mistaken for a snake. Feed on fishes, which they catch dexterously, darting at them with their sharp bill and long neck, swallowing small ones entire, and retiring to a rock to tear the larger in pieces with their claws. Build in trees, nest constructed with sticks: eggs few in number.

Confined to the warm parts of both continents. Species only two.

362. Plotus anhriga, L. Black, varied with hoary : scapulars short, lanceolate; naked space on the throat extensive, black.

Adult, belly black; in spring, hind head with long, slender, black feathers.

Young, neck and beneath whitish.

Black-bellied Darter, Plotus melanogaster, Wils. ix.p. 79. pl. 74. fig. 1. adult. and p. 82. pl. 74. fig. 2. young. P. melanogaster, Vieill. Gal. des Ois. pl. 278. ad. bad figure. Buff.pl. enl. 960. ad.pl. enl. 959. young.

Inhabits during summer the rivers of the southern states: also Mexico and South America : common throughout the year in Florida.*

* Plotus Vaillantii, Temm. Black varied wih hoary; crown rufous, scapulars long, subulate; naked space of the throat very small, yellow.

Adult, beneath black; in breeding season, sides of the neck with long, slender, white feathers.

Young, beneath pale rufous.

Plotus Vaillantii, Temm. pl. col. 380. ad. in full dress. Buff. pl。 enl. 106. bad figure.

Inhabits eastern and southern Africa, India, and Oceania. 


\section{HELIORNIS.*}

Plotus, Gm. Lath. Grebe-Foulques, Buff. Colymbus, Lacepede. Heliornis, Bonaterre. Vieill. Podoa, Ill. Temm. Ranz. Nob. An. Table.

Bill moderate, straight, cylindric-compressed, subulate, somewhat curved and notched at tip, acute; edges sharp, entire; mandibles equal; upper slightly furrowed each side nearly its whole length, depressed above, margins dilated at base; lower straight, angular beneath : nostrils in the furrow, medial, lateral, longitudinal, concave, oblong, covered by a membrane, open in the middle, pervious. Head small, entirely feathered; eyes moderate; neck moderate, slender: body elongated. FEET short; tibiæ almost entirely feathered; tarsi somewhat rounded: anterior toes long, rather slender; hind toe short, touching the ground at tip only; connecting membrane much indented, very deeply scalloped, merely bordering the anterior toes; hind toe not only free, but simple : nails short, compressed, curved, acute. Wings moderate, acute, sub-tuberculated; second and third primaries longest. T TIL spreading, of twelve feathers.

Female similar to the male. Young differing somewhat from the adult. Moult twice a year, hardly changing the colors of their plumage. Plumage very thick, close, and downy. Colors brownish.

Very active. Keep on rivers and creeks, fly well : swim and dive admirably : walk very awkwardly, hardly ever resting but on their favourite element. Feed on fishes and aquatic animals, but especially winged insects, which they seize in the air with great dexterity. Breed on the ground in marshes, near water. Often expanding their wings and tail.

* Having ascertained the priority of this name, we make it a duty to adopt it in preference to that given by Illiger. 
Confined to warm portions of America and Africa. Formed of but two species, differing from each other as the subgenus Holopodius from the other Phalaropodes. Anomalous: buffetted about in different Families, and even Orders. Whatever be its artificial character, its natural station is undoubtedly next to Plotus, as is evident from its form, habits, and especially its skeleton. The digital membrane is so deeply indented, as to give rise to some doubt whether it exists; but the character, though almost obsolete, is still preserved.

363. Hectornis surinamensis, Vieill. Brown, beneath whitish; sides of the neck striped with black and white; bill and feet dusky, the latter barred with black, toes semipalmated; tail rounded, feather's broad.

Surinam Darter, Plotus surinamensis, Lath. Podoa surinamensis, Ill. Le Grebe-Foulque, Buff.pl. enl. 893.

Inhabits the warmest parts of America : an accidental visitant in summer in the middle states.*

\section{FAMILY XXVII. PYGOPODES.}

Pygopodes, Ill. Goldfuss. Brevipennes, Dumeril. Brachypteres, Cuv. Latr. Urinatores, Brachypteri, Vieill. Uria, Oken. Colymbini subalati, Blainville. Colymbi, Alca, Fratercula, Boie. Marangoni, Ditichi, Ranz. Colymbida, Alcada, Vigors. Pygopodes, Lobipedes, Nob. An. Tab. Fam.

BILL short or moderate, more or less compressed, straight, or curved towards the point, acute; margins entire, bent in ; nostrils basal, lateral, narrow, pervious, half closed by a

* Heliornis senegalensis, Vieili. Brown, beneath white; sides of the neck and back speckled with black; bill and feet red; outer toes connected at base only; inner cleft! tail cuneiform, feathers narrow.

Heliornis senegalensis, Vieill. Gal. des. Ois. pl. 280.

Inhabits Africa, particularly Senegal.

VoL. II. 
membrane. Head small, oblong, depressed above, more or less attenuated before; base of the bill more or less feathered: neck of moderate length and strength; body thick, more or less depressed. FEex placed very far back, turned outward, a great portion of the tibia enveloped in the skin of the belly; tarsus shorter than the middle toe, extremely compressed; toes three or four, disposed 3-0, 3-1; three anterior long, slender, either wholly palmated, or lobated; hind toe free, short or wanting: nails moderate, curved, acute, depressed. Wings short ; first, or first second and third primaries longest. TaIL very short, of from twelve to twenty feathers, or wanting, and in its place a tuft of downy feathers.

Female smaller, similar in color to the male. Young differing much from the adult, and changing for several years. Moult twice a year, almost always changing their colors, and in full plumage, sometimes displaying ornamental feathers. Plumage excessively close, often smooth and silvery: down soft, shining, impermeable. Colors generally dull, dark above, beneath white.

Eminently aquatic. Keep almost always in the water, diving and swimming below the surface with unrivalled agility, spreading their wings and using them as fins. Hardly ever walk, and then with the greatest difficulty and awkwardness, the body erect, and resting on the tarsus as well as the toes, almost falling at every step, and when down unable to rise. Flight limited, wings in some totally unfit for it. Feed on fishes, reptiles, insects, and rarely, aquatic plants. Breed in the clefts of rocks, or among water plants near the shore, some in society. Monogamous : eggs very few, mostly one, rarely two. Both sexes sit, and feed the young for some time. Flesh dry, hard, oily, bad tasted, though relished by the Arctic tribes, to whom they are highly useful, supplying them with food and clothing, dresses being made of their skins. Eggs good; young edible.

Spread all over the globe, but chiefly Arctic. Formed of 
our seven genera. Related by some links to the Longipennes, by Mergus to the Lamellosodentati, and by Alca impennis to the Impennes, which return into the Steganopodes.

\section{A. Feet 4-toed.}

Urinatores, Vieill. Colymbi, Boie. Marangoni, Ranz. Colymbida, Vigors.

\section{* Toes lobated.}

83. PODICEPS.

Colymbus, L. Gm. Briss. Ill. Ranz. Podiceps, Temm. Vieill.

BiLL moderate, rather slender, robust, hard, straight, compressed, conic-elongated, acute, entire; upper mandible deeply and broadly furrowed each side at base, somewhat curved at tip; lowểr navicular; edges bent in : nostrils in the furrows, basal, lateral, concave, oblong, pervious, posteriorly half closed by a membrane : tongue moderate, acute, slightly emarginate at tip. Head small, oblong; lores naked; eyes near the bill; neck rather long, slender: body boatshaped, back elevated. FEET turned outward, placed extremely far back; tibia almost hidden in the belly; tarsus shorter than the outer toe, exceedingly compressed, carinated before and behind, posterior carina doubly serrated ; anterior toes greatly depressed, connected at base by a membrane forming a broad lobe all around each toe, outer toe longest, lobe of the middle toe broad, subequal, thrice as broad as that of the lateral; hind toe compressed, articulated internally with the tarsus, equal to a phalanx of the fore toe, edged with a very narrow membrane; internally with a broad rounded one: nails much depressed, quite plane, broad obtuse, not reaching beyond the lobes; middle one largest, slightly pectinated; hind nails very small. Wings short, narrow; three outer primaries subequal, longest. TaIL wanting, in its place a small tuft of short downy feathers. 
Female similar to the male. Young exiremely different from the adult, not assuming their full dress before the second year of their life. Adult generally greatly distinguished by crest and ruffs. Moult in spring and autumn, changing greatly their colors, and periodically losing their ornaments. Plumage remarkably thick, compact and silky, beneath glossy. Colors blackish above, beneath silvery white.

Exclusively aquatic. Live, sleep and breed on the water : keep chiefly on fresh water, very active, swim and dive admirably, springing in the water, moving rapidly on or below the surface; when submerged the neck is stretched, the body elongated, and the wings brought close to it, in order to offer the least resistance, paddling with great speed, the feet moving laterally; descending to great depths in pursuit of fish; owing to which they are often caught in fishermen's nets. Migrate by water : when cast on shore, move their feet and wings unsuccessfully for a long time; never come willingly to land, except to breed: hardly able to walk, standing erect on account of the position of their legs. Flight limited, when elevated, sufficiently rapid. Feed on fishes, reptiles, insects, and occasionally on water plants. Breed in submerged marshes, fixing their nest to reeds and marsh plants near fresh water, often afloat: nest composed of dry grass, lined with down from their own bodies: eggs 3-6, which they cover with down and abandon reluctantiy. Young covered with soft down, beautifully spotted, led by both parents into the water, and soon able to provide for themselves. The mother swims with her young on her back, and keeps them under her wing when diving.

Spread all over the world, but chiefly Arctic, most of the species retiring in summer to cold regions to breed.

$\uparrow$ Bill slender from the base, subcylindric, point straight, subulate. Nostrils elongated. 
364. Podiceps cristatus, Lath. Bill longer than the head, from the front to the tip two inches, reddish, white at the point ; neck beneath, front, and secondaries, white.

Adult in full plumage, neck and breast white; sides of the head reddish, a flat occipital tuft and a broad ruff on each side of the neck, black.

Young dull, obscurely spotted, destitute of the ornamental feathers.

Crested Grebe of Wilson's list. Buff.pl. enl. 400. adult. Id. 944. and 941. young in different stages. Colymbus podiceps, cristatus et urinator, auct.

Inhabits the north of both continents : rare in the middle states, and only during winter : common in the interior and on the lakes.

365. Podiceps rubricollis, Lath. Bill as long as the head, from the front to the tip one inch and a half, yellow, point black; neck beneath reddish; front black; secondaries white.

Adult, cheeks and throat ash-color; neck and beneath rufous; crown, and neck above narrowly, black; a short occipital black crest; no ruff.

Young much duller and spotted; no occipital crest; cheeks and throat white, the former striped with black.

Red-necked Grebe, Lath. Colymbus rubricollis, subcristatus et parotis, auct. Buff.pl. enl. 931.

Inhabits the north of both continents : rare, and during winter only in the middle states: very common in Arctic America.

366. Podrceps connutus, Lath. Bill shorter than the head, one inch long from the front, compressed throughout; secondaries white; twelve outer primaries entirely brown.

Adult blackish, beneath white; neck and breast rufous; a broad black ruff round the neck; a long tuft of reddish feathers behind each eye above. 
Young pure white beneath, nearly meeting on the back of the neck; no ornamental feathers.

Horned Grebe, or Dobchick, Edw. Glean. pl. 145. adult. Black and white Dobchick, Id. pl. 96. fig. 1 young. Buff.pl. enl. 404. fig. 2. adult. 942. young. Colymbus, or Podiceps cornutus, caspicus, nigricans, et obscurus, auct.

Inhabits the north of both continents : common during winter, the young especially, in the middle states.*

\section{†† Bill very stout, especially at base, much compressed,} curved at the point. Nostrils rounded.

367. Podiceps carolinensis, Lath. Bill much shorter than the head, three quarters of an inch long from the front, much compressed throughout, hooked at tip; neck beneath dusky; all the quills brown.

Adult, none of the quills white, feathers of the hind neck elongated, throat black; bill with a black band.

Young ferruginous on the sides; throat white; bill without a band.

Pied-bill Dobchick, Catesb. Car. i.pl. 91. adult. Buff.pl. enl. 943. young. Colymbus podiceps, ludovicianus, Gm. Little Grebe of Wilson's list.

Inhabits the whole continent of America, not extending as

* Podiceps auritus Lath. Bill shorter than the head, five eighths of an nch long from the front, depressed at base, recurved at the point, black; secondaries white; inner primaries white on the inner vane.

Adult blackish, beneath white; neck and breast black; crest and ruff very short, black; a long slender tuft of reddish feathers behind each eye and beneath, covering the ears.

Young pure white beneath, this color extending but little on the occiput; no ornaments.

Eared Dobchick, Edw. Glean. pl. 96. fig. 2. Colymbus auritus, Gm.

Inhabits the north of the old continent, and possibly of America : common in eastern Europe, found in Italy. 
far to the north ; common from Canada to Louisiana, migrating in the middle states. Resembles Podiceps minor of the old continent, with which it has been confounded, but is well distinguished by the bill.

\section{* Toes palmated.}

\section{COLYMBUS.}

Colymbus, L. Gm. Lath. Temm. Vieill. Urinator, Lacep. Mergus, Briss. Eudytes, Ill. Ranz.

BrLc longer than the head, stout, robust, straight, nearly cylindric, compressed, point subulate, acute; edges bent in, sharp, entire; upper mandible somewhat rounded above, slightly curved at the point; lower hardly shorter, quite straight, navicular : nostrils basal, lateral, concave, longitudinal, oblong, pervious, half covered by a membrane : tongue lanceolate, fimbriated backwards at base. Head rather large, narrowed before, the feathers advancing between the nostrils; lores feathered; eyes small, placed near the bill : neck moderate, rather stout : body massive, somewhat depressed. FeET large, placed very far back; tibia almost entirely drawn up. into the belly; tarsus shorter than the outer toe, exceedingly compressed, sharp on both sides, posterior edge simple, entire; anterior toes long, wholly palmated; outer longest; inner shorter than the middle one; hind toe small, touching the ground merely at tip, connected to the outer by a very small rudimental membrane, bordering the inner toe internally at base; nails short, compressed, but somewhat flattened, not reaching beyond the web; middle nail longest, hind nail small, acuminate. Wings moderate; quills stiff; first and second primaries longest. TaIL very short, rounded, of eighteen or twenty feathers.

Female similar to the male. Young very different from the adult until the third or fourth year. Moult twice in the year without changing their colors. Plumage very thick and 
glossy. Colors above remarkably bright for this Family, beneath white.

Live by pairs or small parties : keep during winter at sea, in summer on fresh water. Travel principally by water, very seldom employing the power of flying, which they possess in no inconsiderable degree: fly only in breeding time, or when leading their young to the sea, then high and rapidly. . Dive to the bottom of the deepest rivers with noise, and motion of their wings, but not springing in the water, in paddling move their feet diagonally : dive instantaneously at the flash of a gun, and avoid the shot. When compelled to walk, use their wings against the ground. Feed principally on fishes, which they catch under water and devour on the surface; also on small aquatic animals and plants. Breed near fresh water, generally in some islet: nest of dry aquatic weeds: eggs $2-4$, elongated. Young follow the mother, plunging into water when the nest is disturbed. Voice shrill, acute, terrific.

Inhabit the northern hemisphere, retiring in summer to the highest northern latitndes. Species five, wantonly multiplied.

368. Colymbus glactalts, L. Bill more than four and a quarter inches long; upper mandible straight; lower wider in the middle, channelled beneath, recurved: tail of twenty feathers.

Adult black, speckled with white, beneath white; head and neck glossy black; an interrupted collar and gular band, white.

Young wholly brownish, beneath white.

Great Northern Diver or Loon, Colymbus glacialis, Wils. Am. Orn. ix. pl. $74 \cdot \mathrm{fig} \cdot 3$.

Inhabits the north of both continents : common of all ages, during winter, in the middle states.

369. Colymbus arcticus, L. Bill more than three and a half inches long; upper mandible slightly curved; lower not wider in the middle than at base, not channelled beneath; tail of eighteen feathers. 
Adult black, slightly marked with white, back unspotted ; beneath white; head brownish gray; neck beneath glossy black; a stripe each side of the neck marked with white.

Young ashy-brown, beneath white.

Black-throated Diver, Edw. Glean. pl. 146. adult. Buff. pl. enl. 914. young.

Inhabits the arctic parts of both continents : very rare and accidental during winter in the middle states: common in Arctic America, as well as in some northern parts of Europe.

370. Colymbus septentrionalis, L. Bill three inches long, slightly recurved; edges much bent in; lower mandible channelled; tail of twenty feathers.

Adult blackish, beneath white, head and neck glossy cinereous; neck beneath with a long reddish stripe.

Young ashy-brown, spotted with white, beneath white.

Red-throated Diver, Edw. Glean.pl.97. adult. Buff.pl. enl. 308. adult. 992. young. Colymbus septentrionalis, striatus, stellatus, et borealis. auct. C. septentrionalis, Vieill. Gal. des Ois. 282. adult.

Inhabits the north of both continents: the young only common during winter in the middle states, as well as in Italy.

B. Feet 3-toed.

Brachypteri, Vieill. Alca, Fratercula, Boie. Ditichi, Ranz. Alcada, Vigors.

85. URIA.

Alca, Colymbus, L. Gm. Uria, Briss. Ill. Temm. Ranz. Uria, Alca, Lath. Cephus, Pallas. Uria, Cephus, Cuv. Uria, Cephus, Mergulus, Boie. Uria, Mergulus, Vieill. Brehm.

Bill moderate, slender, robust, smooth, straight, compressed, acute, base feathered; upper mandible convex, somewhat curved at the point, notched; lower hardly shorter, slightly navicular; edges of both bent in, sharp : nostrils in Vor. II. 
a slight rudimental furrow, sub-basal, lateral, concave, longitudinal, linear, pervious, covered partially by the feathers of the front advancing far on the bill: tongue moderate, linear, acute, entire. Head oblong, depressed, narrowed before, rounded posteriorly; eyes small: neck short, moderately robust : body stout, elongated. Feet placed very far back; lower extremity only of the tibia apparent; tarsus one-fourth shorter than the middle toe, slender, compressed, carinated anteriorly : middle toe longest; inner by one third shortest, subequal to the tarsus; webs not very broad: nails compressed, moderately curved, acute ; middle one larger, dilated internally into a sharp edge. Wings short, narrow, acute; first primary longest. TaIL very short, rounded, of twelve feathers.

Female smaller, similar to the male. Young differing from the adult, but almost similar to their winter dress. Moult twice a year, changing the colors of their plumage. Colors black and white.

Keep always near the sea, leaving it only when breeding, not found on fresh water except when straying inland. Walk with difficulty, and only when obliged to cross the ice, in an erect posture. Flight short, though rapid, just skimming the surface of the water : reaching the top of high rocks by jumping and fluttering from point to point. Swim and dive admirably, even beneath the ice, driving their submarine prey by employing their wings as fins, appearing to fly under water. Feed principally on fishes. Breed socially in the clefts of perpendicular rocks: lay without the least preparation on the naked rock, one or two eggs at most, disproportionately large, and with a very hard shell: feed their young with fishes, which they carry to them in their bill. Eggs, feathers, and flesh of the young, sought after.

Inhabit the Arctic seas, whence they migrate in summer to the temperate coasts all round the globe. Our five species are the only well ascertained of the genus. 
Colymbus, L. Gm. Alca, Lath. Uria, Cuv. Vieill. Boie. Bill longer than the head, straight, compressed, subulate, perfectly smooth. Nostrils linear.

* Lower mandible straight along its edge to a small notch at tip.

Cephus? Cuv. Genus Grylle? Leach?

Colors black, changing greatly ị moulting. Not adult before the fourth year. Eggs one ortwo.

371. Uria GryLle, Lath. A large white space on the middle of the wings; feet red.

Summer plumage entirely black, wing coverts white; winter, black, cheeks and beneath white.

Black Guillemot, Edw. pl. 50. back fig. summer dr. Spotred Greenland Dove, Id.l. c. front fig. moulting ind. Uria grylle, balthica, grylloides, lacteola, auct. Uria grylle, Vieill. Gal. des Ois. pl. 294. ad.

Inhabits the north of both continents: not uncommon during winter along the coasts of the United States.

372. Uria marmorata, Lath. Brown, undulated with chesnut; beneath dusky, spotted with white; feet orange; bill black, one inch long.

Marbled Guillemot, Lath. Syn. vi.p. 336.pl. 96. Young. of Uria grylle, Vieill.

Inhabits the north-western coasts of America, and the opposite shore of Asia.

** Both mandibles curved at the point.

Uria, Leach?

Colors beneath white at all times; the throat only changing from black to white in moulting. Young obtain the adult plumage in the second year: lay but one egg. 
373. Uria troile, Lath. Blackish, beneath white; secondaries white at tip ; feet dusky; bill longer than the head, much compressed throughout, upper mandible four times as long as broad.

Adult, a black stripe behind the eyes; summer plumage, whole head jet black.

Young duller, no black stripe behind the eye.

Lesser and Foolish Guillemot, Lath. Buff. pl. enl. 903. summer dress. Foolish Guillemot, Edw. Glean.pl.359.fig.1. summer dress. Uria lomvia, Brunn. Colymbus troile, $\boldsymbol{L}$.

Inhabits the Arctic regions of both continents: common during winter on the coasts of the United States.

374. Uria brunnichir, Sabine. Sooty-blackish, beneath white; secondaries white at tip; feet greenish; bill as long as the head, dilated and broad at base, upper mandible three times as long as broad.

Summer plumage, whole head black.

Uria francsii, Leach. Uria troile, Brunn. nec auct.

Inhabits the Arctic seas of both continents : not uncommon during winter on the coasts of the northern and middle states : very numerous in Davis' Straits, Baffin's Bay, \&c.

SUBGENUS II. MERGULUS.

Mergulus, Ray Vieill. Boie.Brehm. Uria, Lath. Alca, L. Gm. Cephus, Cuv ?*

Bill very short, a little curved, conic-convex, hardly compressed, nearly as broad as high: both mandibles notched; upper slightly sulcated: nostrils rounded; tongue thick, entire : smallest of the Order.

* We now adopt the generally received and older name Mergulus, and reject Cephus, which we had heretofore used, principally because Cuvier, who instituted that subgenus, has made an inextricable confusion, by giving as the type Uria grylle, though he probably intended for it this bird. 
Feed on small crustacea, which they collect under their tongue. Breed socially: eggs but one, bluish-white. Flight rapid, long sustained : travel as much in the air as in the water: walk better than the other species.

Form the passage to the genus Phaleris, by Phaleris cristatella.

375. URiA ALLE, Temm. Black, beneath and tips of the secondaries white, under the wings black; bill and feet black; bill very short, half as long as the head, a little curved.

Summer plumage, whole head black.

Little Auk, Alca alle, Wils. Am. Orn. ix. p. 94. pl. 74. fig. 5. Buff. pl. enl. 917. winter dress. Uria minor, Briss. Mergulus alle. Vieill. Gal. des Ois. 295. adult.

Inhabits the north of both continents, migrating in winter to the coasts of the United States and Europe.

\section{PHALERIS.}

Alca, L. Gm. Lath. Vieill. Mormon, Fratercula, Cuv. Phaleris, Temm. Ranz.

BILL shorter than the head, dilated on the margins, almost quadrangular, notched near the tip ; upper mandible depressed on the sides, convex above; curved at the point ; lower somewhat compressed, angular beneath, truncated at tip : nostrils medial, marginal, linear, pervious, half closed by a naked membrane : tongue thick, entire. Head small, capistrum advancing but little on the base of the bill : eyes small : neck short, stout, body massive. FEET placed very far back : tibiæ almost entirely drawn up into the belly ; tarsus shorter than the middle toe, slender, compressed, sharply carinated on both sides; toes long, very slender, middle toe longest; inner shortest: webs full, entire: nails much incurved, very acute; middle one longer, dilated internally. Wings short, acute; first primary longest. TaIL of fourteen feathers, of which the middle and outer are shortest. 
Female similar to the male. Young differing from the adult. Moult twice in the year, undergoing little or no change of color.

Reside throughout the year in Arctic regions, very confined in their migrations. Live socially at sea, swimming among the ice with much grace and dexterity, retiring at night to the clefts of rocks, or to burrows dug with their bill and feet. Feed on crustacea, mollusca, and other small marine animals. Lay without any preparation, in holes of rocks, or in their burrows, a single egg. Exceedingly stupid : easily killed or taken. Eggs and skin useful to the Arctic tribes.

Inhabit the Polar seas between Asia and America. Formed of three species, of which one is not well determined.

376. Phaleris psittacula, Temm. Black; belly white; a line behind the eyes, and a spot above, white; ridge of the bill compressed.

Adult, bill red.

Young, bill yellowish-dusky.

Alca psittacula et tetracula, Lath. Perroquet, and Dusky Auk, Syn. v. 95. fig. 2. and 3. the head.

Inhabits the north-western coasts of America, and the opposite ones of Asia : common in Kamtschatka.*

* Phaleris cristatella, Temm. Blackish, beneath lighter, tinged with bluish on the breast, and yellowish on the vent; a frontal tuft of six or eight feathers curling over the bill ; sides of the head ornamented with long, slender, white feathers ; ridge of the bill hardly compressed, lower mandible with a groove each side from the throat.

Young black, beneath white; no tuft.

Alca cristatella, et pygmaea, Lath. Crested, or Flat-billed Auk, Lath. Syn. iii. pl. 95. fig. 4. the head. Phaleris cristatella, Temm. pl. col. 200. adult. Alca cristatella, Vieill. Gal. Ois. pl.297. adult.

Inhabits the seas of Japan, and the north-eastern coast of Asia, especially Kamtschatka. Visits also in all probability, the opposite western shores of North America. Allied to our last Uria. Alca antiqua of Lath. is most probably a third North American species of Phaleris. 


\section{8\%. CERORHINCA.}

Phaleris, Nob. Suppl. Am. Gen. in Zool. Journal. (29)

BiLL shorter than the head, much compressed throughout, much longer than high; perfectly smooth, base not much feathered, covered by a callous membrane, surmounted by a long, obtuse, horn-like process, (rising perpendicularly on the base of the bill); both mandibles curved and slightly notched at tip ; lower strongly angular beneath, not truncated, acute, from the angle to the base each side inferiorly a very deep, linear, inconspicuous groove; edges sharp, those of the upper mandible much dilated, of the lower remarkably bent in at base: nostrils situated beneath the callous cere, marginal, long, linear, pervious, very apparent, half closed by the membrane; tongue short, slender, depressed and bifid at tip? Head globular, orbits feathered; eyes small; neck short, stout: body plump. FEET placed exceedingly far back ; tibia almost entirely drawn in ; tarsus moderately compressed, one-third shorter than the middle toe, very rough behind; toes long, slender, smooth beneath ; middle longest; inner one third shortest, equal to the tarsus : webs moderately broad, entire : nails compressed, curved, acute; middle one largest, dilated internally into a sharp edge. Wings short, slender, rather acute; quills blunt, first a little the longest, secondaries much abbreviated. TAIL very short, slightly rounded, of fourteen feathers, much rounded at tip.

Changes and habits most probably similar to those of the allied genera.

Inhabits the sea between America and Asia, hitherto only obtained from the western coast of North America. Well entitled to generic distinction. Not more allied to any other genus of Pygopodes than they are to each other, intermediate between Phaleris and Mormon, but more closely related to the latter by the sheath covering the bill, which differs in form only, and the great depression of that member. 
377. Cerorhinca occidentalis, Nob. Blackish, belly whitish; a few slender, elongated, white feathers at the corners of the eyes and mouth : bill yellow.

Phaleris cerorhinca, Nob. l. c. Id. Am. Orn. iv.pl. Not mentioned in my catalogue.

Inhabits the western coasts of North America.

88. IMORMON.

Alca, L. Gm. Lath. Spheniscus, Moehring. Fratercula, Briss. Cuv. Mormon, Ill. Temm. Ranz. Larva, (since Fratercula), Vieill.

BiLL shorter than the head, exceedingly compressed, higher than long, at base as high as the head, obliquely sulcated on the sides, covered at base by a wrinkled, callous membrane; both mandibles much curved and notched; upper with the base on a level with the crown, ridge sharp, higher than the front; lower a little shorter, obtuse: angles of the mouth margined with an extensible membrane: nostrils placed near the callous cere, marginal, long, linear, obsolete, almost entirely closed by a naked membrane : tongue short, compressed, very acute. Head globular; orbits naked; eyes small; neck short, thick: body plump. FEeT placed exceedingly far back; thighs almost entirely drawn in; tarsus one third shorter than the middle toe, rather slender, carinated above and behind; toes slender; middle somewhat longest; inner one third shorter than the outer: webs moderately broad, slightly indented, projecting a little beyond the toes: nails compressed, much curved, very acute, middle one largest, the inner most incurved. WIngs short, slender, acute. TAIL short, of sixteen feathers, the middle and outer shortest.

Female similar to the male. Young differing but little from the adult, except by their small and smoother bill. Moult twice a year, colors of their plumage changing but 
little. Chick at first covered with a very long down, much longer than that of the adult.

Live socially in Arctic seas, whence they migrate partially in winter: keeping near the shores and retiring at night, and in stormy weather, to clefts or burrows. Swim and dive admirably, to great depths: walk better than the allied species. Flight short, skimming the water, assisting it by striking the surface with their feet, rarely a little elevated. Feed on crustacea, mollusca, and other small marine animals, with a few sea-weeds, cutting their food with their bill before swallowing it. Build in great numbers on cliffs, generally digging burrows with their bill and claws in the earth collected in the cavities of rocks; lay a single hardshelled egg, of greatly disproportioned size. Very affectionate parents, fighting boldly in defence of their young. Seen flying among the rocks only when carrying them food in their bill.

Confined to the most northern latitudes throughout the globe. Species well ascertained, only our three.

378. Mormon crrreatus, Temm. Blackish, quill shafts white; eye-brows white, posteriorly cirrhated; bill moderately compressed, furnished at base with an osseous sheath, upper mandible only grooved.

Young, bill smooth, no ornaments.

Tufted Auk, Alca cirrhata, Lath. Buff.pl.enl. 761. Fratercula cirrhata, Vieill. Gal. 296. adult. Omitted in my Catalogue.

Inhabits the sea between North America and Kamtschatka, often seen on the western coasts of the United States in winter. Appears to come nearest to Cerorhinca, by the sheath of its bill only differing in shape from that of that singular bird.

379. Monnon glacialis, Leach. Black, beneath white, a broad black collar; bill exceedingly high, moderately compressed, both mandibles with at most two grooves before the nostrils, lower extremely curved.

VoL. II. 
Young, bill much smaller, hardly grooved.

Puffin of Wilson's list? Mormon glacialis, Leach. Never figured. Omitted in my Catalogue.

Inhabits the Arctic parts of both continents : not uncommon in winter on the coasts of the United States : a rare and accidental winter visitant in northern Europe.

380. Monmon arcticus, Ill. Black, beneath white; a broad collar round the neck black; bill red, exceedingly compressed, both mandibles with at least three lateral grooves before the nostrils, lower but little curved.

Young, bill yellowish-dusky, smooth.

Puffin of Wilson's list? Buff. pl. enl. 275. adult. Alcu arctica, I. A. labradora, et deleata, auct. Mormon fratercula, Temm.

Inhabits the north of both continents, migrating in winter to the temperate shores of the United States and Europe.

\section{9.* ALCA.}

Alca, L. Gm. Briss. Lath. Ill. Cuv. Temm. Vieill. Ranz. Chenalopex, Moehring. Torda, Dumeril. Penguin, Lacep.

BiLL shorter than the head, robust, cultrate-compressed, broad at base, higher in the middle, feathered to the nostrils, hence much compressed, swoln, grooved and plaitel on the sides, hooked at the point; margins angular; upper mandible convex, strongly curved from the middle, hooked and acute at tip; lower gibbous below the point, shorter, obliquely truncated; thick feathers of the face advancing on both mandibles to the middle: nostrils medial, marginal, short, linear, pervious, half closed by the feathered membrane, not perceptible: tongue thick, oblong, entire, acute. Head

* Having decided to adopt Garrulus as an independent genus, composed of Garrulus and Pica, subgenera of Corvus, the total nnmber of our North American genera is carried to ninety. 
moderate, depressed, narrow before, rounded behind; eyes small: neck short, thick : body massive. TrBı much drawn in ; tarsus one third shorter than the middle toe, moderately robust, carinated on both sides; toes rather stout, middle slightly longest; inner shortest : webs not very broad, entire : nails moderately curved, acute, middle largest, dilated slightly into an edge. Wings short, acute; quills acute; first primary longest; secondaries much abbreviated. TAIL or twelve or sixteen acute feathers.

Female perfectly similar to the male. Young well distinguished from the adult by their small and nearly smooth bill. Moult twice in the year, changing the colors of their head. Feathers short.

Live at sea among the ice, not far from shore: those that can, fly rapidly, though short distances : throwing themselves into the sea instantaneously without alighting on the surface. Walk with extreme awkwardness, and bearing much upon the tarsus, so that the species that cannot fly, must either swim of crawl. Feed on fishes and smaller marine animals, which they catch by diving : swim and dive admirably well. Breed socially in caves and clefts of rocks, where they also retire at night : lay but a single egg, disproportionately large. Young abundantly fed by the parents, even for some time after leaving the nest.

Arctic : formed of two widely difierent species, one of which does not leave the polar circle.

381. Alca torda, L. Black, beneath white; wings capable of flight, when folded reaching to the rump; tail moderate, cuneiform, of twelve feathers.

Adult, bill with three or four lateral grooves: summer plumage, whole head black: a white line from the bill to the eye.

Young, bill smooth.

Razor-bill of Wilson's list. Buff. pl. enl. 1003. summer dr. 1004. winter plumage. Alca pica and torda, L. A. balthica, uni-sulcata, et minor, auct. 
Inhabits the north of both continents : common in winter along the coasts of the United States : found occasionally on those of Italy. Forms the transition from the genus Uria, especially Uria troile, which it closely resembles in plumage.*

* Alca impennis, L. Black, beneath white; wings extremely short, useless for flight; tail rounded, very short, of sixteen feather's.

Adult, bill sulcate; summer plumage, whole head and throat black; a large white spot each side of the bill.

Young, bill smooth; no white spot on the front.

Great Auk, Edw. pl. 147. Buff.pl. enl. 367.

Inhabits the Arctic seas of both continents, where it is almost constantly resident. Connects the Family Pygopodes, with the last of all, that of Impennes, having no representative in our hemisphere. 


\section{APPENDIX}

\section{To the "Genera of North American Birds, and Synopsis of the Species found in the United States."}

Note 1. Falco velox. We have in another place quoted as doubtful synonymes of this species, Falco dubius, and Falco obscurus of authors, but have not restored to the species its old name, finding it next to impossible to arrive at any certainty relative to these meagre indications. Since this note was first written, however, we have had sufficient proofs to warrant us in asserting that Falco obscurus is "a young female" of $\boldsymbol{F}$. columbarius ; and that Falco dubius is undoubtedly Wilson's supposed new species. Falco fuscus of authors is another and still prior name for the same, and we shall therefore adopt it.

We have also a new species to be added to the same section. These discoveries render it necessary to replace this part of the Synopsis with the following.

13 bis. Falco cooperir, Nob. Tail rounded, with four blackish bands, and tipped with white; wings reaching to the second band; second quill subequal to the sixth, third to the fifth. Length eighteen inches or more.

Adult unknown. Young dusky-brown, skirted with ferruginous; beneath white, with oblanceolate dusky-brown spots.

Cooper's Hawk, Falco cooperii, Nob. Am. Orn. ii. pl. 10. fig. 1. young.

Inhabits North America : appearing in autumn and the beginning of winter in the middle states.

14. Falco fuscus, Gm. Tail even, with four blackish bands, 
and tipped with white; wings reaching to the second band; second quill much shorter than the sixth; third than the fifth. Length about one foot.

Adult, slate-color, beneath white, barred with ferruginous.

Young, dark brown, skirted with ferruginous; beneath white, with oblong ferruginous spots.

Falco pensylvanicus, and Falco velox, Wilson. Falco dubius, Gm. Lath. Dubious Falcon, Penn. Arct. Zool. Lath. Syn. Falco fuscus, (Miller. Ill. pl. 18?) Gm. Lath. American Brown Hawk, Lath. Syn.

Note 2. Falco borealis. It will be proper to remark, that this species is almost as much an Astur of the first section as a Buteo. Falco hyemalis on the contrary, is decidedly a typical Buteo : the very young of these two species are so similar, that they can only be distinguished by the slight differences of the bill and claws, and by the length of the primaries, the fourth being the longest in $F$. borealis, while it is the fifth in F. hyemalis. To one or other of these species, in their various states, most probably to the former, must be referred Buteo ferruginicaudus, B. fuscus, and B. gallinivorus, of Vieill. Ois. d'Amerique. This conjecture is founded on the examination of a fine series of specimens of Falco borealis in my collection, of all ages, and exhibiting all the gradations of color. The changes of $\boldsymbol{F}$. hyemalis are not yet satisfactorily explained, and we would direct the attention of American Ornithologists to the subject.

The Broad-winged Hawk of Wilson, Falco pensylvanicus, of which we lately examined several specimens, is erroneously referred to Astur; it is a typical Buteo. The young wants the white on the tail, that part being obsoletely banded with black and dusky, the inferior parts are pure white, with rare blackish oblanceolate spots. It may at once be known from the two other Buteones, by its much smaller size, and wider, though more obscure tail-bands. The female is, however, even more than is usual, larger than the male. The adult is clouded beneath; tail barred with white.

Falco melanopterus. We are now of opinion, that the bird described by us under this name, is a distinct species peculiar to America, and may be characterised as follows. 
16. Falco dispar, Temm. Bluish-gray, beneath white; wingcoverts black; tail even, outer feather shortest.

White-tailed Hawk, Falco dispar, Nob. Am. Orn. ii.pl. 11. fig. 2 adult female. Milan a queue irreguliere, $F$. dispar, Temm. pl. col. young.

Inhabits the southern states, Mexico, and South America.*

Note 3. Strix cunicularia. We may now dismiss any doubt as to the identity of the North and South American, as well as the West Indian Burrowing Owl. They all belong to one and the same species, and there will be no need of my proposed conditional name, hypudaa. So different from our bird is Temminck's plate of his Strix grallaria, that when he stated his bird to be the S. cunicularia of the systems, that I had almost taken it for granted, that my name was to be adopted. The difference, however, is owing to the inaccuracy of the French plate, for I have identified the specimens. This owl is well described by d'Azzara, who gives an excellent account of its habits.

Note 4. Strix virgterara. Cuvier errs in arranging this bird in his subgenus Otus, of which the auricular conch is semicircularly extended from the bill to the top of the head, and furnished with a large membranous operculum. In the character of the ear, the S. virginiana corresponds with S. bubo of Europe, and this learned naturalist ought, therefore, to have referred our species to his subgenus Bubo. In these two closely allied species, we begin to observe the enlarged opening of the ears, so conspicuous in the following subgenus, Ulula. They are perfectly intermediate between our two subgenera Surnia and Ulula, and with the Syrnia of Savigny, might indeed form a separate subgenus.

Since writing the above, having ascertained the existence in this

* Falco melanopterus, Dand. Bluish-gray, beneath white, wing-coverts black; tail even, outer feather longest.

Black-winged Hawk, Lath. Le Blac, Le Vaill. Ois. d'Afrique, adult and young.

Inhabits the whole continent of Africa, widely spread in the hot climates of Asia, found in Java, New Holland, \&c. 
country, of another species of the same group, we think proper to introduce it regularly into the Fauna of the United States.

SUBGENUS I. bis. BUBO.

Bubo, Syrnium, Sav. Cuv.

Conch of the ear moderate, oval, with a membranous operculum. Feet thickly covered to the claws with short feathers.

* Head tufted. (Bubo, Cuv.)

Disk of feathers not well marked.

27. Strix virginiana, $\mathrm{Gm}$.

* Head not tufted. (Syrnium, Cuv.)

Disk of feathers perfect and well marked.

27. bis. Strix cinerea, Gm. Dark brown mottled with whitish; face white, with black concentric circles; tail reaching beyond the wings; both fasciated, the bands mottled; bill yellowish-white; irides yellow.

Cinereous Owl, Strix cinerea, Nob. Am. Orn. pl.23. fig.2. Strix lapponica? Retz? Temm?

Inhabits Arctic America : an accidental winter visitant of the north-western territory: common throughout the year at Hudson's Bay : found in winter at Fort William on Lake Superior. Length more than two feet. The largest American species.

Note 5. Strix ACAdica. On a recent examination of this bird, I ascertained that the auricular conch and its operculum, are as large as in any of the genus, by which it may at once be known from $\mathbf{S}$. passerina: We cannot sufficiently regret, that authors should be so unanimous in neglecting this important character of the ears in owls. Owing to this neglect, we are unable, even at the present moment, to decide whether our S. acadica is the S. acadica, or S. T'engmalmi of Temm. and other modern authors.

Note 6. Strnix Flammea. S. bubo, and S. phalanoides of Daud. are also indicated by Say in Long's Ex. and several other species are stated to inhabit North America. We have also heard Mr. Audubon mention a small species with a deeply forked tail! 
Note 7. Coccyzus eryturoptiralmus. We strongly suspect C. cinereus, Vieill. taken from D'Azzara, to be no other than Wilson's $\boldsymbol{C}$. erythropthalmus : according to the same author, $\boldsymbol{C u}$ culus seniculus is also a summer visitant of the southern states.

Note 8. Picus tridactylus. Misled by Temminck and all other authors, we have fallen into several errors regarding this species. Having lately carefully studied it, we are now enabled to characterize it accurately in all its states.

46. Picus tridactylus, L. Bill very broad, depressed; tarsus feathered above; sides of the head striped with black and white.

Male glossy black, beneath white ; top of the head yellow. Female glossy black, beneath white; crown wholly black.

Young, black lineated with white; crown finely streaked with white.

Northern three-toed Woodpecker, Picus tridactylus, Nob. Am. Orn. ii. pl. 14. fig. 2 .

Inhabits the north of both continents.

Note 9. Quiscalus Ferrugineus. Oriolus niger, Black Oriole, $\mathrm{Gm}$. Jath, quoted by Wilson, and at first by myself in my Observations, under the above species, is a different bird, inhabiting the West Indies and South America. It forms a fourth well ascertained species of this genus. In the general system, its place is between $\boldsymbol{Q}$. versicolor and Q. ferrugineus, and as it may easily be mistaken, I shall characterise it.

Quiscalus baritus, Nob. Glossy black; tail much rounded, reaching beyond the wings more than two inches; osseous carina small : length ten inches.

Female but little smaller, dull brownish ; beneath and eyebrows, whitish.

Synonyms. Gracula barita, L. (Gm ? applies to the present as well as to Q. versicolor, ) not of Lath. Icterus niger, Briss. Quiscalus baritus, Vieill? Agelaius niger, Vieill. Oriolus niger, Gm. Lath. Oriolus oryzivorus? Gm. Lath. Troupiale noir de St. Domingue, Buff. pl. enl. 534. Black Oriole, Penn. Latk. Syn. Rice Oriole? Lath. syn. Ploceus oryzivorus, or niger, Cuv.

Vor. II. 
Inhabits the West Indies and South America.

Note 10. Convus Pica. A second North American magpie is described by Mr. Sabine, in the Zool. App. to Franklin Ex. under the name of C. hudsonius, but it has not yet been found within the limits of the U. S.

The following species of the subgenus Garrulus, (which we shall hereafter adopt as a genus), and the Bombycilla garrula have lately been discovered to inhabit the United States.

63. bis. Corvus stellert, Gm. Crested; blue; head and neck blackish; secondaries and tail-feathers slightly banded with black, tail rounded.

Corvus stelleri, Gm. Lath. Nob. Am. Orn. ii. pl. 13. fig.1.

Inhabits the western coasts of North America, especially the shores of the Oregan, and Nootka Sound. Found also in Mexico.

65. bis. Bombycilla garrula, Vieill. Drab; throat, frontlet, and line over the eye, black; belly cinereous, vent rufous; wings and tail blackish, the latter tipped with yellow.

Bombycilla garrula, Nob. Am. Crn. iii. pl. 16. fig. 2. Ampelis garrulus, $\boldsymbol{L}$.

Inhabits near the Rocky Mountains : for a long time well known in the north of Europe and Asia.

Note 11. Lanius septentrionalis. Being now convinced that Lanius borealis, Vieill. is identical with $L$. septentrionalis, Gm. Lath. we accordingly restore the original name to this species. Syn. Northern Shrike, Lath. Synops. Great Shrike, Penn. Arct. Zool.

After Myiothera, p. 74. introduce the following genus.

20. bis. CINCLUSS.

Sturnus, L. Gm. Tringa! Briss. Motacilla, Scopoli. Turdus, Lath. Cinclus, Bechst. Ill. Cuv. Temm. Ranz. Hydrobata, Vieill.

Bill moderate, slender, straight, compressed-subulate, feathered at the base; edges sharp, slightly incurved; upper 
mandible curved at tip, slightly notched, somewhat obtuse; lower slightly recurved at the point : nostrils basal, lateral, concave, longitudinal, covered by a membrane : tongue cartilaginous, bifid at tip. Tarsi longer than the middle toe, smooth; heel naked; inner toe free, hardly longer than the hind one: lateral toes equal. Wings short, rounded; spurious feather very short; third and fourth primaries longest. Tall short.

Female hardly differing in plumage from the male: young more tinged with reddish. Moult annually. Plumage water proof.

Solitary. Frequent brooks and clear streams, diving, and walking on the gravelly bottom beneath the surface of the water, which appears to be their favourite element. Feed on aquatic insects, and small crustacea. Build in the vicinity of rivulets, hiding the nest carefully. Flight rapid, straight, skimming the surface of the water. Voice feeble, shrill.

Inhabit the north of both continents. Composed of but two intimately allied species, both probably Asiatic, though one is found in Europe, and the other in North America. Remotely allied to the order Grallæ by their habits, and naked heel; but belonging decidedly to this Family (Canori).

94. bis. Cinclus paliasir, Temm. Wholly dark cinereous.

Cinclus Pallasii, Nob. Am. Orn. iii. pl. 16. fig. 1.

Cinclus mexicanus, Swainson in Phil. Mag. new series.

Inhabits near the Rocky Mountains, and in Mexico : also probably north-eastern Asia.

Note 12. Sxuvia peregriva. I can hardly doubt of the identity of this and S. bicolor of Vieill. pl. 90. bis. They differ only in one being described as blue, and the other as green, which colors sometimes interchange according to the incidence of light. If I am right, V's name of course must be adopted.

Note 13. Since this part of the Synopsis was printed, we have determined by comparison, the identity of Troglodytes adon and 
Sylvia furva. The species ought therefore to be called Troglodytes furvus (fulvus?)

Note 14. Troglodytes europeus. We have not been able to detect any distinctive mark between the European and American Wren, although their habits are different. If they should prove distinct, the appropriate name $\mathbf{T} \boldsymbol{r}$. hyemalis, Vieill. must prevail.

Page 103. Emberiza. Add the following species.

\section{SUBGENUS PLECTROPHANES.}

158. bis. Emberiza rapponica, Nilss. Quills black; two outer tail-feathers brownish-black, with a white spot at tip; hind nail very long, straight.

Male in full plumage, head and breast black; beneath white, neck above bright rufous.

Male in winter, female and young, blackish skirted with rufous, beneath white.

I apland Longspur, Emberiza lapponica, Nob. ii. pl. 13. fig. 2. male. fig. young female. Fringilla lapponica, $\boldsymbol{L}$. Emberiza calcarata, Temm.

Inhabits the northern regions of both continents, breeding within the Arctic circle, descending in severe winters in large flocks to the most northern parts of the United States.

159. Emberiza nivalis, L. Quills white, the six exterior widely black at the point; tail black, three outer feathers white at base; hind nail curved.

Note 15. Fringilla pensy lvanica. This species and the following, approach very near the subgenus Fringilla. The truth is, that this and Spiza, like many others, pass insensibly into each other.

Note 16. If this synonym be correct, the ungrammatical name melodia, must give place to that of fasciata.

Note 17. Fringilla erytiropthalma. This somewhat anomalous species, forms the type of Vieillot's genus Pipilo. Several 
species allied to it, have very recently been discovered in Mexico : they form a small, very natural group, which it is but just to adopt at least as a subgenus, under the name of Pipilo.

Note 18. Loxia curvirostra. Another species, which from its close resemblance to this, may perhaps have been mistaken for it, probably inhabits America. It is somewhat larger, and may be distinguished by the following phrase.

Loxia pytiopsittacus, Bechst. Wings without bands ; bill shorter than the rniddle toe, very stout, very much incurved, point of the upper mandible not crossing the top of the bill.

Inhabits the Arctic circle, descending in winter to more temperate countries: said by authors to be found in America.

Note 19. Columba zenaida. Another species of Pigeon, pro. bably Columba rufina, Temm. inhabits the keys of East Florida ac. cording to Mr. Peale, who was unable to procure it, though it is well known to the wreckers. Other West Indian Pigeons most probably resort there either periodically or accidentally.

Note 20. Tetrao phasianeluus. Other species of grouse, which inhabit high northern latitudes, may hereafter be found to stray occasionally to the extreme northern parts of the U.S.

Since this was written, having detected several errors in our ac. count of this genus, owing principally to the bad state of the specimens we first examined, and having, moreover, a stately new species to add, we give the following amended version of this part of the Synopsis, page 126.

SUBGENUS I. BONASIA.

(Add to thecharacters.) Tail elongated, rounded. Adorned with crests and ruffs. Female similar to the male. Flesh white.

205. Tetrao umbeluus, L. Mottled; tail of eighteen mottled feathers, all ferruginous, and with a black subterminal band.

Male, a ruff of large black feathers on the sides of the neck. Female and young, ruff smaller, dark brown. 
Flesh black.

206. Tetrao cupido, L. Mottled; tail rather short, much rounded, of eighteen plain dusky feathers; primaries spotted with white outside.

Male, neck furnished with wing-like appendages, \&c.

206. bis. Tetrao urophasianus, Nob. Tail cuneiform, of twenty narrow, tapering, acute feathers.

Male black.

Female and young mottled.

Cock of the plains, Tetrao urophasianus, Nob. Am. Orn. iii. $p l \cdot 21 \cdot f i g \cdot 2$.

Inhabits the extensive plains near the sources of the Missouri. The largest of North American Grouse. Size of T. urogallus, which replaces it in Europe.

207. Tetrao obscurus, Say. Tail slightly rounded, of twenty broad, rounded, blackish feathers; primaries unspotted.

Male black. Female and young dusky, somewhat mottled.

Dusky Grous, Tetrao obscurus, Nob. Am. Orn. iii. pl. 18. female.

Inhabits near the Rocky Mountains. Size of T. tetrix of Europe, of which it is the analogue.

208. Tetrao canadensis, L. Tail moderate, rounded, of sixteen black, rounded feathers; breast, flanks, and tail-coverts spotted with white.

Male black, waved with gray; throat and breast deep black.

Female mottled; throat and breast banded with black and rufous.

Spotted Grous, Tetrao canadensis, Nob. Am. Orn. iii. pl. 22. male. pl. 23. fig. 1. female.

Inhabits the north of America, extending to the Rocky Mountains : found in Maine, Michigan, and New-York. 
209. Tetrao phasianeluus. Mottled; tail short, cuneiform, of eighteen narrow, square feathers, the two middle much the longest, the outer white at the point.

Female similar to the male. Winter plumage, much darker and more glossy.

Sharp-tailed Grous, Tetrao phasianellus, Nob. Am. Orn. iii. $p l$. 29 .

Inhabits the high northern regions of America, as well as the high range of the Rocky Mountains.

Note 21. Ardea pealit. We think proper to give the equivalent phrase for the European Little Egret.

Ardea garzetta, $\boldsymbol{L}$. Crested ; snowy white ; bill very slender, four inches long, and with the legs, black; toes yellowish ; tarsus less than four inches long.

Adult, crest small, of but two or three slender, elongated feathers ; a large neck-fringe of compact, subulate feathers; back with long flowing silky plumes.

Young and moulting hardly crested, and without the dorsal train.

Little Egret, Lath. Sgarza minore bianca, St. degli uccelli. iv. pl. 423. and 424 .

Inhabits Asia, and eastern, as well as southern Europe.

Note 22. Tantalus fuscus. It is now well ascertained that there is an Ibis fusca, distinct from the young of I. rubra, but we have not been able to trace it in the United States.

Note 23. (24. by mistake.) Numenius brevirostris, Temm. In stating that this new species of Lichtenstein differs essentially from Latham's $N$. borealis, Temminck, who, like all modern writers, appears to be very little acquainted with the North American Numenii, must have had in view our N. hudsonicus, Lath. (Scolopax borealis, Gm.) These two birds have always been confounded or mistaken for each other, and even by Latham himself, through inadvertence, as is proved by the name he has selected from Gmelin, and above all by its synonymy.

The fact is, that the North American Numenii have never been properly understood; but we hope that the phrases we have given will settle them as three distinct species; and as they are 
besides, even at the present advanced state of the science, confounded with the European, of which there are also three species, which, contrary to the generally received opinion, are all and each distinct from the American, (though two only are reckoned by the best authorities, one of which is even referred to an American,) we take this opportunity of giving phrases also for the European species, thus carrying to six instead of three, the number of European and North American Numenii. For a detailed description and account of each species, and the extrication of the almost endless confusion reigning throughout the works of preceding authors, see our "Monography of the genus Numenius," (ined.) and our "Observations Nom. Wils. Orn."

\section{European Numenii.}

1. Numenius arquata, Lath. Crown deep brown, with whitish streaks, no medial line; rump white; long axillary feathers pure white; bill long, not much arcuated.

Le Courlis, Buffon pl. enl. 818.

Inhabits common throughout Europe, Asia, and northern Africa: abounding most to the north, from western Iceland to eastern Kamtschatka : found in England at all times, in Italy only a winter visitant. Analogous to $N$. longirostris.

2. Numenius phaopus, Lath. Crown deep brown, with a whitish medial line; rump white; long axillary feathers banded with black and white; bill short, much arcuated.

Le Corlieu, Buff. pl. enl. 842.

Inhabits throughout the old continent, New Holland, and the adjacent islands : breeds within the Arctic circle : we have ourselves identified specimens from Java. Rare in the vicinity of Rome. Analogous to $N$. hudsonicus.

3. Numenius tenuirostris, Vieill. Crown brown, streaked with whitish ; rump and ground color of the tail, pure white ; long axillary feathers pure white; bill short, slender, not much arcuated.

Never figured.

I was the first to discover this species in Europe; and following the practice of modern ornithologists, ought to have considered it as new: but on referring to the pages of Vieillot, in the second edition 
of the new Dict. of Nat. His. I found the indication of an Egyptian species, which agreed very well with my Italian specimens, and thought better to adopt his appropriate name, than to coin a new one.

Inhabits Italy during winter : never observed elsewhere but in Egypt. In the neighbourhood of Rome it is the most common species, (the arquata is also common, but the phropus extremely rare.) From the circumstance of its being entirely a winter bird, I am led to suppose that it may be found all over Europe, where it may have been taken for the young of $N$. arquata, which it resembles greatly ; but its pure white tail-feathers, andits beautiful arrowshaped spots (instead of streaks) on the bieast, together with its diminutive size, and shorter and smaller tarsi and toes, will always distinguish it. It comes to us in September and October, and departs in April. It is observed in large flocks in the damp meadows bordering on the Tyber, where they sometimes sit the whole day facing the wind. They sing loudly and incessantly, are very suspicious, and keep sentinels to warn them of danger. They are caught in great numbers in nets, being decoyed by imitating their whistle, or by showing them a living, or even a stuffed specimen, of their own species, or of the Vanellus cristatus. Analogous to N. borealis; but the similarity is not quite so striking as that of the others.

It is remarkable that all the European species of the genus $\mathrm{Nu}$. menius, have white rumps and white under wing-coverts, whilst each and all the American have the former uniform with the rest, and the latter rusty.

Note 24. Scolopax wilsonir. I was the first to perceive that this species was distinct from S. gallinago, (See "Observations on the Nom. of Wils. Orn. sp. 204.") and intended to distinguish it by the very equitable name it now bears, but waited until it could be proved distinct from S. Brehmii, another European species. This was first done by 'Temminck. Our right, therefore, to impose a name on the species, cannot justly be disputed.

Temminck is, however, mistaken when, judging from dried skins, he states that the American snipe is by an inch shorter than both the above mentioned European, for it is generally as large, and often larger.

Note 25. That the authors of the "Illustrations of Ornithology," VoL. II. 
should not have recognised in their Lobipes incanus, the young of a well known species, and should have given in that state a sixth specific name to a bird only discovered a few years ago, is not much to be wondered at ; but what is not a little extraordinary, is that they, who are so justly scrupulous about priority, should adopt for Phalaropus wilsonii, Sabine, the much posterior name of Temm. posterior even to that of Vieillot, thus slighting over one of the few and best positive zoological labours of their countrymen, even after it had been sanctioned by others.

Note 26. The abolition of one Family, the addition of seven genera, and other important modifications of the Order ANseres, render it necessary to give the following improved edition of that part of our Analytical Table.

\section{ORDER V. ANSERES.}

Tarsi compressed, abbreviated : tibia almost always partly naked : toes palmated.

32. Longipennes. Hind toe free, or wanting: margins of the bill entire: wings long, acute.

* Bill of one piece, nostrils simple.

** Upper mandible seamed, nostrils simple.

*** Both mandibles seamed : nostrils tubular.

33. Lamellosodentati. Hind toe free: margins of the bill denticulated.
* Teeth lamelliform.
** Teeth conic.

34. Steganopodes. Toes four, all connected by a broad membrane.

* Bill seamed. * Bill not seamed.

35. Pygopodes. Hind toe free or wanting : margins of the bill entire, wings short, rounded.

* Four-toed. ** Three-toed.

36. ImPENNES. Hind toe free, directed forwards : no quills nor tail. 


\section{ORDER ANSERES.}

\section{Family Longipennes.}

* Bill of one piece : nostrils immarginate : 4-toed.

64. Rhincops. Lower mandible much longer than the upper, truncated.

65. Sterna. Bill subulate, straightish, compressed, acute.

66. Larus. Upper mandible hooked.

** Upper mand. seamed : nostrils immarginate: 4-toed.

67. Lestris. Upper mandible hooked, covered at base with a cere.

*** Both mandibles seamed : nostrils tubular : 4-toed.

A: Hind toe only a sharp nail.

68. Thalassidrona. Bill weak, both mandibles curved; nostrils united in a common tube; second and third primaries longest.

69. Proceltaria. Bill robust, lower mandible truncated; nostrils in a single tube : first primary longest. Tail of fourteen feathers.

70. Pufrinus. Both mandibles strongly curved : opening of the nostrils distinct.

B. No hind nail.

71. Diomedea.

Family Lamellosodentat

72. Anser. Bill higher than broad, stout, conic; teeth short, conic-acute; lora feathered.

73. Cygnus. Bill at base higher than broad, depressed; teeth laminar; lora naked. 
74. Anas. Bill broader than high, depressed; teeth long, lamelliform; hind toe simple.

75. Fuligula. Bill broader than high, depressed; teeth lamelliform; hind toe lobated.

76. Mergus. Bill slender, hooked; teeth subulate.

Family Steganopopes.

* Bill seamed above.

77. Pelecanus. Bill much depressed; edges entire.

78. Phalacrocorax. Bill cylindrical, hooked; edges entire, feet entirely palmated; outer toe longest; tail rounded.

79. Tachypetes. Bill cylindrical, both mandibles hooked, edges entire ; feet semipalmated ; middle toe much the longest; tarsi feathered; tail forled.

80. Sula. Bill stout, straight, compressed; edges serrated.

** Bill not seamed.

81. Phacton. Bill cultrate; edges serrated; face feathered.

82. Plotus. Bill subulate; edges serrated; face naked.

83. Helionnis. Bill subulate; edges entire; face feathered. Toes lobated, lobes scalloped, connecting membrane rudimentary.

Family Pygopodes.

* Four-toed.

84. Podiceps. Toes lobated : lora naked; no tail.

S5. Colymbus. Toes palmated : lora feathered.

** Three-toed.

86. UrIA. Bill nearly straight, pointed: nostrils half closed by a feathered mernbrane. 
87. Phaleris. Bill very short, curved, sub-quadrangular: nostrils pervious, half closed by a naked membrane.

88. Cerorhinca. Bill curved, compressed, longer than high, surmounted at base by a long obtuse process : nostrils pervious, not feathered.

89. Mormon. Bill curved, exceedingly compressed, highel than long: nostrils half closed by a naked membrane.

90. Alca. Bill curved, exceedingly compressed : nostrils half closed by a feathered membrane.

Note 27. Thalassidroma. We shall here add the specific phrases of the two other species of this genus with which we are acquainted, and which we have ourselves distinguished from those in the text.

3. Thalassidroma pelagica, Vigors. Sooty-black; upper tailcoverts white with black tips; tail even, the wings reaching a little beyond it ; tube of the nostrils straightish ; tarsus seven-eighths of an inch long.

Procellaria pelagica, Temm. Nob. Jour. Ac. Phil.iv. p. 227. pl viii..

Inhabits the coasts of Europe, principally those of Great Britain and its northern isles : found also in the Mediterranean.

4. Thalassidroma oceanica, Nob. Brownish-black; upper tailcoverts wholly white; tail slightly emarginate, the wings reaching more than an inch beyond it ; tube of the nostrils recurved ; tarsus nearly one inch and three quarters long.

Stormy petrel, Lath. Synop. Le Petrel ou oiseau tempete, Buff. pl. enl. 993. Procellaria oceanica, Nob. Zool. Jour. Lond. iv. p. 7.

Inhabits the South Seas : common near the Cape of Good Hope, and the island of 'Tristan d'Acunha.

In the Turin Museum, superintended by the learned Bonelli, I had the good fortune to find a second specimen of this interesting species, which was obtained near the island Tristan da Acunha. The following observations were made at the time. 
Length eight and a half inches (French); tarsus eighteen lines. Bill ten lines, with the nasal tube recurved : feet remarkably broad, without yellow spots: tail perfectly even. The colors are the same as in the other specimens on which I established the species; there is no white on the wings, but the lower parts from the breast, including the flanks, are pure white, (the other, if I recollect right, though we remarked that even in that state, it had more white than any other, was merely varied with white), with the exception of the tips of the lower coverts and femorals : a few white feathers appear also on the throat, the bottom of the plumage of which, as well as that of the breast is, moreover, pure white, leading us to suspect that those parts may become entirely white according to season. The outer tail feather is also white at base, as well as the shaft : the same thing is observed in Thalassidroma pelagica, but the shaft is black even in the white. The principal and most remarkable character, however, of this species, a character which I also observed in the other specimen, but did not notice, fearing it to be artificial, is the following :

The nails are plane, (quite flat) dilated and rounded at tip, quite different from those of the other species, though a slight tendency to that form is observable in Th. wilsonii, and somewhat resembling those of the species of the genus Podiceps.

Shall we place in a separate group an account of this remarkable anomaly, a bird which in all other respects is a decided Thalassidroma? According to Temm. this species is the Procellaria marina, (verbal communication) but judging from Vieillot's plate and description in the Gal. des Ois. pl. 292. even making allowance for the white, we cannot admit such an identity, though the birds are certainly much alike.

Note 28. Our 35th Family (Lobipedes) must be abolished. Of the two genera which composed it, the first, Podoa, belongs decidedly to the Steganopodes; and the other, Podiceps, no less certainly to the Pygopodes, and in a natural arrangement should not be separated from Colymbus, any more than Podoa from Plotus. Our apology for proposing this artificial group, may be found in the remains of a prejudice in favour of the long since established Order of Pinnatipedes. Latham was the first to force into that most unnatural assemblage, the three genera Podiceps, Fulica, and Pha- 
laropus; and'Temminck made it still more heterogeneous, by adding the genus Podoa. No four genera are in fact, less allied as a group than these, and when in our arrangement we restored to their true situation, Fulica and Phalaropus, it was through prejudice only that we left Podiceps and Podoa together in the same Family.

Note 29. Cenoriunca. The new species which forms the type of this genus, was first announced by us in the Journal here cited, and we then referred it to the genus Phaleris, under the name of $P$. cerorhynca, suggesting, however, that it might form a group by itself, and upon further consideration, we have decided to propose it as such.

The total number of our North American genera, has been increased from eighty, to ninety. The genera added are, Garrulus, Cinclus, Aramus, Thalassidroma, Pufinus, Anser, Cygnus, Fuligula, Phaleris, Cerorhinca.

The six species of birds referred to in the note, p. 296. to be added to the first three Orders, are Strix cinerea, Corvus stelleri, Bombycilla garrula, Cinclus pallasii, Embcriza lapponica, and Tetrao urophasianus. To these must now be added, Falco cooperii, so that the total number of United States species comprised in our Synopsis and Appendix, amounts to 382. 


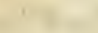

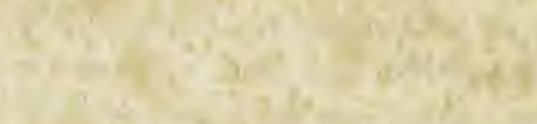

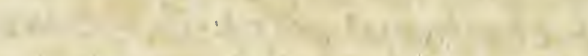$$
\text { is }
$$$$
+\frac{1}{2}+\frac{1}{i}
$$

-

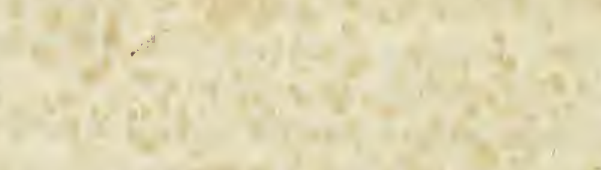

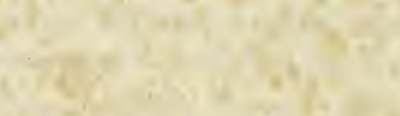

$$
\begin{aligned}
& \text { 1. }
\end{aligned}
$$

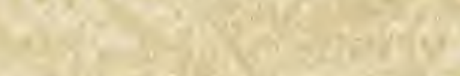

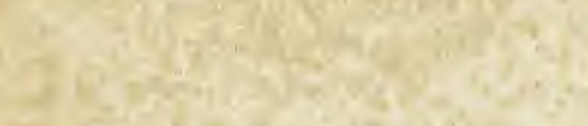

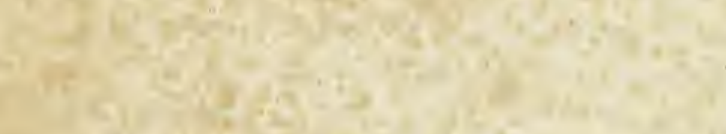

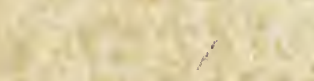

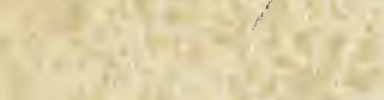

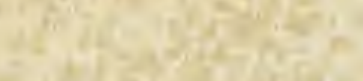

(1)

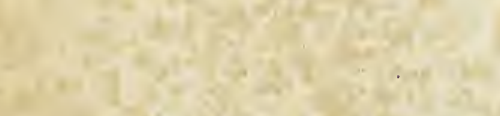

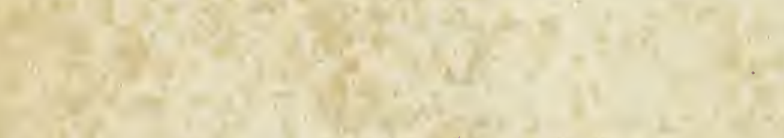

114353

$x^{2}=1,1$

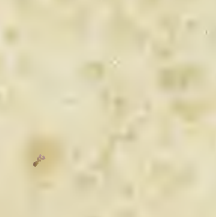





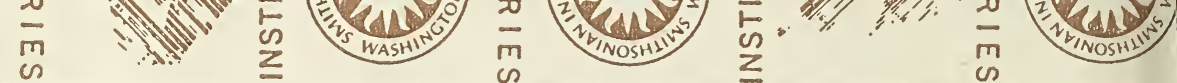
ES SMITHSONIAN INSTITUTION NOILIIIISNI NHINOSHLIWS S
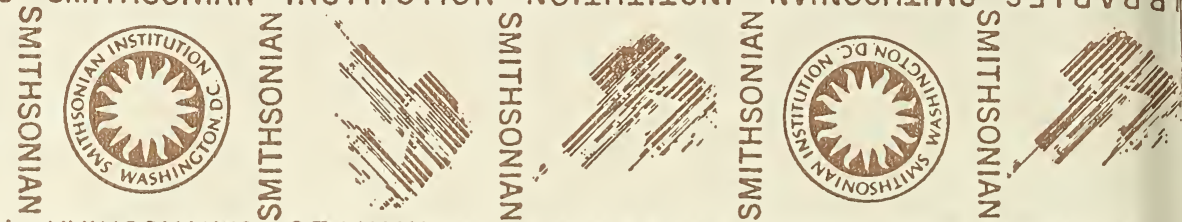

SNI NHINOSHLINS
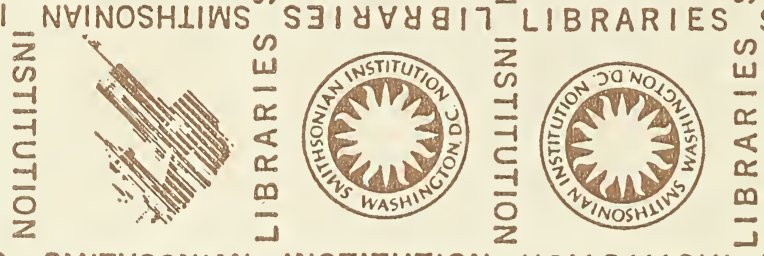

INSTITUTIO

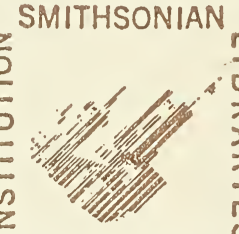

INSTITUTION
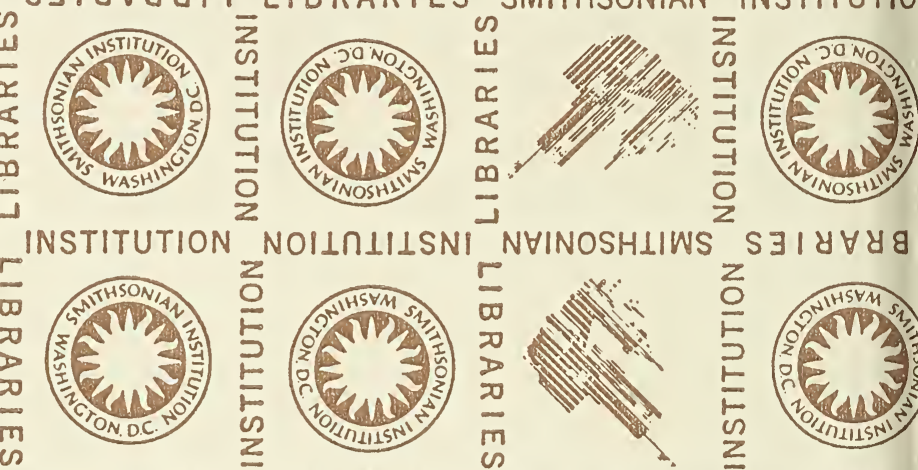

NHINOSHLIWS

$S \exists 18 \forall \forall 9$

NVINOSHLIWS

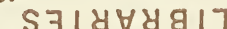
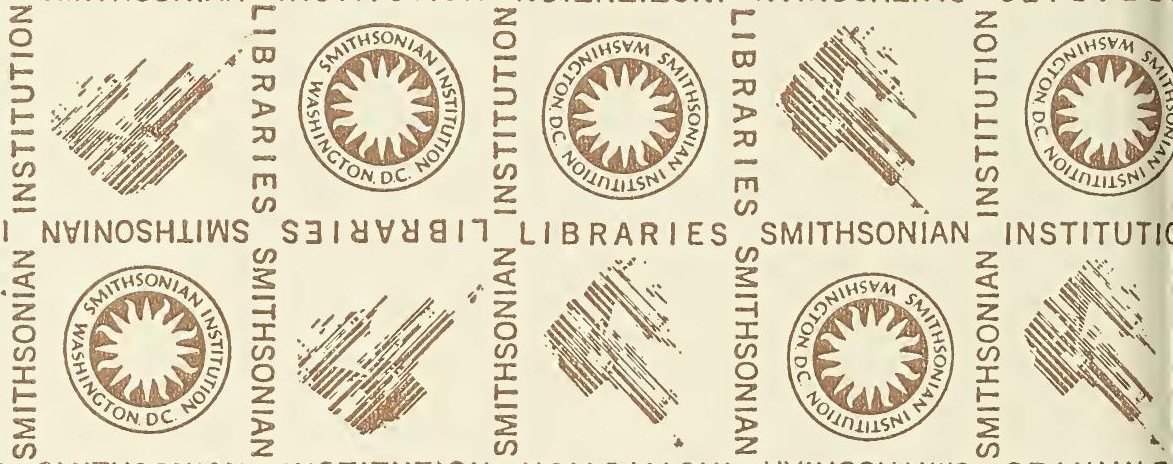

ES SMITHSONIAN
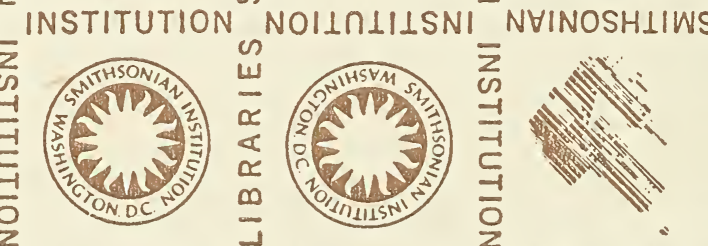

S $\exists 18 \forall \forall 8$
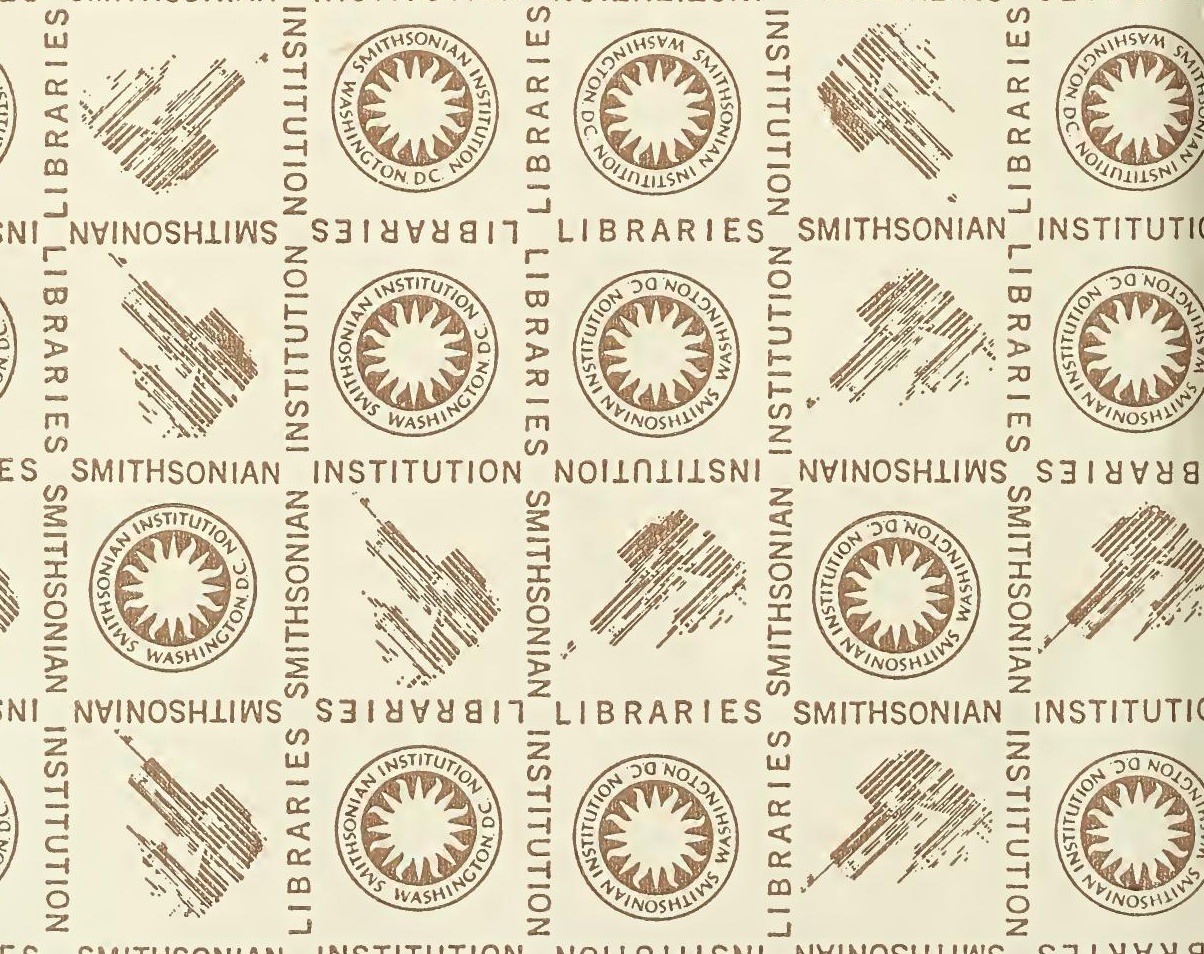

ES SMITHSONIAN

INSTITUTION 
